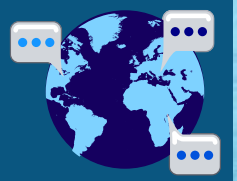

languages

\title{
Studies in Historical
}

Linguistics and

Language Change

Grammaticalization,

Refunctionalization and Beyond

Edited by

Dorien Nieuwenhuijsen and Mar Garachana Printed Edition of the Special Issue Published in Languages 


\section{Studies in Historical Linguistics and Language Change}





\section{Studies in Historical Linguistics and Language Change. Grammaticalization, Refunctionalization and Beyond}

Special Issue Editors

Dorien Nieuwenhuijsen

Mar Garachana 
Special Issue Editors

Dorien Nieuwenhuijsen

Mar Garachana

Utrecht University

Barcelona University

The Netherlands

Spain

\section{Editorial Office}

MDPI

St. Alban-Anlage 66

4052 Basel, Switzerland

This is a reprint of articles from the Special Issue published online in the open access journal Languages (ISSN 2226-471X) from 2018 to 2019 (available at: https://www.mdpi.com/journal/languages/ special_issues/Lingustics_LanguageChange)

For citation purposes, cite each article independently as indicated on the article page online and as indicated below:

LastName, A.A.; LastName, B.B.; LastName, C.C. Article Title. Journal Name Year, Article Number, Page Range.

ISBN 978-3-03921-576-8 (Pbk)

ISBN 978-3-03921-577-5 (PDF)

Cover image courtesy of Bob de Jonge.

(C) 2019 by the authors. Articles in this book are Open Access and distributed under the Creative Commons Attribution (CC BY) license, which allows users to download, copy and build upon published articles, as long as the author and publisher are properly credited, which ensures maximum dissemination and a wider impact of our publications.

The book as a whole is distributed by MDPI under the terms and conditions of the Creative Commons license CC BY-NC-ND. 


\section{Contents}

About the Special Issue Editors $\ldots \ldots \ldots \ldots \ldots \ldots$ vii

\section{Dorien Nieuwenhuijsen and Mar Garachana Camarero}

Introduction

Reprinted from: Languages 2019, 4, 34, doi:10.3390/languages4020034 . . . . . . . . . . . . . 1

Christopher J. Pountain

The Development of the Articles in Castilian: A Functional Approach

Reprinted from: Languages 2019, 4, 20, doi:10.3390/languages4020020 . . . . . . . . . . . 6

\section{Enrique Pato}

Indefinite Article + Possessive + Noun in Spanish: A Case of Refunctionalization?

Reprinted from: Languages 2018, 3, 44, doi:10.3390/languages3040044 . . . . . . . . . . . . . 23

Malte Rosemeyer

Refunctionalization and Usage Frequency: An Exploratory Questionnaire Study

Reprinted from: Languages 2018, 3, 39, doi:10.3390/languages3040039 . . . . . . . . . . . . . . 31

Rolf Kailuweit

Exaptation, Refunctionalization, Decapitalization—BE + Past Participle with Intransitive Verbs in Mediaeval and Early Modern Spanish

Reprinted from: Languages 2018, 3, 43, doi:10.3390/languages3040043 . . . . . . . . . . . . . 47

\section{Axel Hernández Díaz}

Refunctionalization. First-Person Plural of the Verb Haber in the History of Spanish

Reprinted from: Languages 2019, 4, 6, doi:10.3390/languages4010006

Concepción Company Company

Grammatical Words and Spreading of Contexts: Evidence from the Spanish Preposition $a$

Reprinted from: Languages 2019, 4, 10, doi:10.3390/languages4010010 . . . . . . . . . . . . 75

Esther Artigas

On the Latin Origins of Spanish mediante

Reprinted from: Languages 2019, 4, 15, doi:10.3390/languages4010015 . . . . . . . . . . . . . 91

\section{Mar Garachana}

The History of the Spanish Preposition Mediante. Beyond the Theory of Grammaticalization

Reprinted from: Languages 2019, 4, 26, doi:10.3390/languages4020026 . . . . . . . . . . . . . 109

María Elena Azofra Sierra

The Role of Elision in Evolutionary Processes

Reprinted from: Languages 2019, 4, 12, doi:10.3390/languages4010012 . . . . . . . . . . . . . 133

\section{Dorien Nieuwenhuijsen}

On the History of Ante(s): Exaptation of Adverbial -s?

Reprinted from: Languages 2018, 3, 45, doi:10.3390/languages3040045 . . . . . . . . . . . . . 143 



\section{About the Special Issue Editors}

Dorien Nieuwenhuijsen is Associate Professor in Spanish Linguistics at Utrecht University. Her research is focused on the historical development of Spanish, especially Spanish syntax, and on variation and change in contemporary Spanish, in Spain and Spanish America. She is particularly interested in the role internal and external factors play in linguistic variation and change. To recollect her data she uses large digital language corpora and she takes a special interest in the opportunities these digital tools offer for the study of historical linguistics. She takes part in the research project Diccionario histórico de las perífrasis verbales del español. Gramática, pragmática y discurso (II). Perífrasis temporales y aspectuales (MINECO FFI2016-77397-P). She is a member of the research group Grup de Gramàtica i Diacronia (Gradia) recognised as 'consolidated' by the Agència de Gestió d'Ajuts Universitaris i de Recerca (AGAUR) of the Generalitat de Catalunya (2017 SGR 1337).

Mar Garachana is a teacher of Hispanic Linguistics at the University of Barcelona. Her main research interests lie within corpus linguistics, grammaticalization and constructionalization. She has published amongst others on Spanish and Catalan discourse markers and articles evolution, on verbal periphrases constructionalization and on the change of Spanish grammar in language contact contexts. She coordinates the research project Diccionario histórico de las perífrasis verbales del español. Gramática, pragmática y discurso (II). Perífrasis temporales y aspectuales (MINECO FFI2016-77397-P). She also directs the research group Grup de Gramàtica i Diacronia (Gradia) recognised as 'consolidated' by the Agència de Gestió d'Ajuts Universitaris i de Recerca (AGAUR) of the Generalitat de Catalunya (2017 SGR 1337). 



\title{
Editorial
}

\section{Introduction}

\author{
Dorien Nieuwenhuijsen ${ }^{1, *}$ and Mar Garachana Camarero ${ }^{2, *}$ \\ 1 Faculty of Humanities, Department of Languages, Literature and Communication, Utrecht Institute of \\ Linguistics OTS, Utrecht University, 3512 JK Utrecht, The Netherlands \\ 2 Department of Hispanic Studies, Literary Theory and Communication, University of Barcelona, \\ 08007 Barcelona, Spain \\ * Correspondence: D.Nieuwenhuijsen@uu.nl (D.N.); mgarachana@gmail.com (M.G.C.)
}

Received: 6 May 2019; Accepted: 17 May 2019; Published: 4 June 2019

It is a commonly known fact that language change can be observed at different linguistic levels, which correspond to the traditional disciplines of phonology, morphology, syntax and semantics. In this special issue we concentrate on morphological and syntactic changes in Spanish, although we do not exclude phonological or semantic change, as long as they are linked to or relevant for the discussion of a certain morphological or syntactic evolution.

Whereas grammatical change for many decades has been an important issue in the work of a number of Spanish historical linguists, the interest in this kind of change received a strong boost with the development of grammaticalization studies, which undoubtedly have greatly enhanced our knowledge of concrete linguistic evolutionary processes, as well as our understanding of the evolution of grammar in general ${ }^{1}$.

Work on grammaticalization developed mainly from the late twentieth century onwards. However, it was far from being a novelty then, since various previous studies already touched upon this concept, particularly several nineteenth-century German linguists who dealt with central issues of grammaticalization studies. The term itself was coined by Meillet in 1912 (Meillet 1912), and Kuryłowicz returned to the concept and the process of grammaticalization in 1965 (Kuryłowicz 1965). A few years later, Givón (1971) elaborated further on the topic, but it was not until 1982 that the first monograph on grammaticalization was conceived by Lehmann (only published in (Lehmann 1995); for more information see Narrog and Heine 2011). Finally, the decade of the nineties meant the consolidation of grammaticalization as an approach for studying grammatical change. It provided a framework that made it possible to systemize the study of grammatical change, understood as the evolution from a lexical item or construction to a grammatical word or as the transition from a grammatical item to a more grammatical item.

Unquestionably, numerous processes of grammatical change fit in this definition. However, others, such as the development of the preterite subjunctive in Spanish or the emergence of prepositions such as Old Spanish no obstante ('in spite of') or no embargante ('notwithstanding'), fall outside the limits of grammaticalization proper. Therefore, alternative approaches arose in order to explain how these and other changes took place.

Concepts such as exaptation, capitalization, refunctionalization and adfunctionalization emerged as a result of the need to explain certain evolutionary processes that did not match with the evolutionary patterns proposed by grammaticalization theory. For instance, it is not unusual that languages recycle grammatical material for uses different from its original etymological use. That was the case with Latin

1 As historical linguists, we concentrate on changes in the course of recorded history, not on the development of human language capacity in general. In that sense, we assume that "the historical record (all written until about a century and a half ago, when live recording began) reflects modern cognitive ability and a stable stage in the evolved human language capacity" (Traugot 2008, p. 219). 
plural neuter nouns that ended in $-a$, whose ending in Spanish, instead of being a plural marker, came to be reanalyzed as a singular feminine marker of collective nouns as words like leña prove (from Latin neuter lignum, plural ligna, 'wood', hence 'firewood' in Spanish; cf. Penny 2004, p. 122). Interestingly, the change that experimented these Latin neuter plural nouns in their transition to Spanish took place at the morphosyntactic as well as the lexical level. However, a grammaticalization path cannot be invoked to explain the reinterpretation of this ending, since it goes beyond the mere reanalysis of endings in $-a$ as feminine markers in Vulgar Latin, as it also entails the retention of the original plural sense in the collective meaning of these words.

In his well-known and much debated article of 1990, Lass launched the notion of exaptation, which refers to "the opportunistic co-optation of a feature whose origin is unrelated or only marginally related to its later use" (Lass 1990, p. 80). Borrowed from evolutionary biology, he used this term to describe a kind of linguistic evolution in which a grammatical element is recycled and redeployed for a new linguistic purpose. In line with Lass's $(1990,1997)$ ideas, it may be maintained that in the course of time the plural neuter marker $-a$ had become obsolete, since only the masculine and feminine gender survived as such in Spanish, and plural meaning was expressed by $-s$. While neuter singular nouns, ending in $-u m$, in most cases became masculine in Spanish $(-u m>-o)$, the neuter plural marker in $-a$ had become a sort of morphological junk, a useless piece that could be exploited in order to signal collectivity. Obviously, the fact that feminine nouns in Spanish frequently ended in $-a$ favored the morphological integration of this type of nouns.

Connecting with Lass' original idea, Pountain (2000, p. 295) proposed the term capitalization, which he defined as "an attempt to label the historical process by which a linguistic feature which already exists in a language comes to be substantially exploited for wider purposes, sometimes simply making overt distinctions which were previously covert, but sometimes apparently creating new expressive possibilities".

Subsequently, in order to distinguish between instances of exaptation in which the original function had been lost and instances in which a new function was added to the original one, and to clarify the somewhat diffuse concept of exaptation, Smith (2011) introduced two types of change: refunctionalization and adfunctionalization. He categorized the evolution of the Latin plural neuter nouns as a case of adfunctionalization, i.e., "the process in which a form assumes a new function alongside or in addition to its original function" (Smith 2011, p. 305), arguing that the number opposition of singular/plural continued to exist, but was no longer expressed by the original neuter morphology (Smith 2011, p. 296).

More recently, Van de Velde and Norde (2016) have traced the origin and history of the concept of exaptation, showing that ever since its introduction it has been susceptible to divergent interpretations, leading to terminological confusion and controversy. Broadening the scope of the term, the authors conceive exaptation as "the leap-like co-optation of a trait for a new function that is not immediately related to its former function" (Van de Velde and Norde 2016, p. 10). For Van de Velde \& Norde the key issue is no longer whether the new function corresponds to an obsolete word or grammatical function, but the fact that the evolution does not follow its predicted or common course. In this way, exaptation has been applied to deal with unexpected changes. In Spanish, examples can be found in the acquiring of a subjunctive value by the pluperfect indicative (CANTAVERAM; Rodríguez 2006, p. 174 ff.) or in the extension of the definite article at the head of completive that-clauses (Wall and Octavio de Toledo y Huerta 2016) as in El que no sepas caminar y mascar chicle al mismo tiempo no significa que el resto de la raza humana sea como tú. ('That you do not know how to walk and chew gum at the same time does not mean that the rest of the human race is like you.').

In spite of the indisputable merits of grammaticalization theory and concepts as exaptation, capitalization, refuncionalization or adfuncionalization, they generally disregard or do not properly allow for other aspects that are highly relevant for certain grammatical changes. As a matter of fact, languages are not only used in specific conversational contexts, but they are also employed in written texts, and as Narrog and Ohori (2011) showed, a grammatical change may also start or develop in 
this latter modality. In the same vein, even so-called dead languages, as is the case with Latin in the European medieval countries, may generate linguistic innovations, that originated either in written texts or in language employed in formal contexts (cf. Jover 2010). These innovations in Latin were transferred to European vernaculars via written texts and, afterwards, were introduced into the spoken language through formal registers. Since, in our view, these features are an integrated part of certain types of grammatical changes, it is essential to take into account the cultural and social context in which these particular changes occur.

The present special issue examines the usefulness and applicability of a number of the above-mentioned concepts and processes of change to a range of linguistic changes in Spanish and Latin that cannot be easily or can only be partially accounted for within the framework of grammaticalization. Rather than challenging the insights of grammaticalization theory, the different contributions to this special issue demonstrate that exaptation, capitalization, refunctionalization and adfunctionalization, as well as changes motivated by rhetorical guidelines, constitute interesting and valuable notions that allow for a better understanding of specific language changes in Spanish and, by extension, of language change in general.

This special issue consists of three parts that focus on different components of the grammar. Each part comprises a number of case studies on specific grammatical topics in Spanish or Latin. Ideally, the reader should read the papers in the order we establish below, since this order, we believe, renders a thematically coherent overview of the work included in the present issue.

However, every paper may also be read independently and actually, as the reader will find out, the order of the papers on the journal website differs from the one proposed here. Thus, the reader may also play hopscotch, as in Julio Cortázar's famous novel Rayuela/Hopscotch, and read the papers in his own preferred order, or simply follow the order of the journal website.

Pountain opens the first part of this special issue, which concentrates on changes in the noun phrase. The author argues that the development of the definite and indefinite articles in Spanish may be regarded as an instance of capitalization or adfunctionalization. His meticulous quantitative and qualitative analysis reveals that the definite article is the result of a partial exaptation of the Latin demonstrative ILLE, whereas the indefinite article still preserves its original value of numeral. However, as Pountain shows, both articles developed additional functions, related to the original ones.

Pato studies the history of the sequence <indefinite article + possessive + noun $>$, as in un su amigo (literally 'a his friend'), which existed in Medieval Spanish, fell in disuse in Modern Peninsular Spanish but has survived in some Spanish American dialects, particularly in Central American Spanish, although with a new discursive value. The claim of the author that the construction can be understood as an example of refunctionalization is convincingly grounded in a qualitative analysis of the distinct values of the possessive construction.

The third contribution concerning the noun phrase explores the relationship between refunctionalization and usage frequency. Rosemeyer proposes that folk etymology processes can be characterized as a type of refunctionalization, since in folk etymology obsolescent morphemes are replaced with morphemes that still have a function in language. In order to test this claim, he conducted a questionnaire survey in which participants were asked if they accepted the assumption that a target word derived from a proposed etymon that, however, was false. Rosemeyer's results indicate that usage frequency plays a role in folk etymology processes and, hence, in refunctionalization.

The second part of the special issue, dedicated to changes in the verb phrase, starts with a contribution by Kailuweit, who studies the use of $<$ to be + past participle $>$ with intransitive verbs in Medieval and Early Modern Spanish. Whereas in Latin <ESSE + past participle $>$ mainly had an aorist reading, Medieval Spanish <ser + past participle $>$ has to be interpreted as a resultative construction, thus challenging the common assumption of a grammaticalization path from resultative constructions to aorist constructions. In order to describe this process adequately, the author introduces the term decapitalization reversing Pountain's concept of capitalization. 
Hernández Díaz analyzes the diachronic development of the first person plural verb form habemos (literally 'we have', now 'there are'), which originally was a full verb expressing possessive meaning but in the course of time became an auxiliary of perfect tense and in Modern Spanish has an existential value. Hernández Díaz argues that the recycling of habemos can be conceived as a case of refunctionalization, triggered by the fact that it presents communicative advantages that other existential verbs lack.

The topic of part three is the origin and development of a number of discourse markers and grammatical words. In her contribution, Company stresses the necessity to consider context as the unit of language change when grammatical words are involved, being context always the locus of change in this particular cases. Typically, these changes exhibit an active spreading of a form to new contexts, which, however, does not entail a change in category or grammatical status. Evidence for these claims comes from the diachronic expansion of the Spanish preposition $a$ ('to').

The next two contributions discuss the evolution of the Spanish preposition mediante ('by means of, with') in different historical and diachronic periods. Artigas examines its origins in Late Latin and analyses the different uses of the verb MEDIARE ('to be in the middle, to mediate'), particularly its present participle in ablative form MEDIANTE. This analysis allows her to shed light on the linguistic and extra-linguistic circumstances that accompanied the emergence and behavior of mediante in the first centuries of Spanish. At the same time, her work highlights the more general issue of the importance of discursive traditions and historical-cultural factors in the evolution of linguistic units.

Garachana Camarero studies the origin of the use of the preposition mediante ('by means of, with') in Medieval Spanish. She argues that, whereas traditionally its presence has been described as the result of a process of grammaticalization, empirical data extracted from two large digital diachronic corpora support the claim that this preposition is the outcome of a grammatical calque of Latin that entered the Spanish language through Aragonese and Catalan.

Subsequently, Azofra analyzes the role of elision in the evolutionary process of the additive connective aparte ('besides') and shows that this particle, that presents serious problems of categorization, as reflected in various lexicological works, introduces an argument that is not indispensable to reach a certain conclusion. In this sense, it is different from all other additive connectors in Spanish. The author uses the case of aparte to draw some more general conclusions on the explanatory force of grammaticalization theory and, at the same time, highlights the importance of context as the locus of change.

In the last contribution to this special issue, Nieuwenhuijsen studies the historical development of the Spanish doublet ante-antes ('before') and explores the question whether the adverbial $-s$, as present in antes, was exploited to mark a semantic difference between the two forms, once the original adverbial value of final $-s$ had become obsolete. Quantitative data are presented to test this claim and to analyze the distribution of the different meanings of the two members of the doublet.

We would like to express our gratitude to the anonymous reviewers of the papers of this issue, whose comments have definitely helped to improve the research that is presented here. Our special thanks go to Christopher J. Pountain for helping with the English editing of several papers.

Funding: This research was partly funded by the projects Diccionario histórico de las perífrasis verbales del español. Gramática, pragmática y discurso (MINECO FFI2013-43092-P) and Gradia. Grup de Gramàtica i Diacronia (AGAUR 2017 SGR 01337). The Utrecht Institute of Linguistics OTS supported the editing of a preliminary version of the manuscript.

Conflicts of Interest: The authors declare no conflict of interest.

\section{References}

Givón, Talmy. 1971. Historical Syntax and Synchronic Morphology: An Archaeologist's Field Trip. Chicago Linguistic Society 7: 394-415.

Jover, Barra Mario. 2010. Cómo Vive Una Lengua 'muerta': El Peso Del Latín Medieval En La Evolución Romance. In Modelos Latinos en la Castilla Medieval. Edited by Mónica Castillo Lluch and Marta López Izquierdo. Madrid and Frankfurt am Main: Iberoamericana \& Vervuert, pp. 63-79. 
Kuryłowicz, Jerzy. 1965. The Evolution of Grammatical Categories. Diogenes 13: 55-71. [CrossRef]

Lass, Roger. 1990. How to Do Things with Junk: Exaptation in Language Evolution. Journal of Linguistics 26: 79-102. [CrossRef]

Lass, Roger. 1997. Historical Linguistics and Language Change. Cambridge: Cambridge University Press.

Lehmann, Christian. 1995. Thoughts on Grammaticalization. Munich: LINCOM.

Meillet, Antoine. 1912. L'évolution Des Formes Grammaticales. Scientia 12: 130-48.

Narrog, Heiko, and Bernd Heine. 2011. The Oxford Handbook of Grammaticalization. Oxford: Oxford University Press.

Narrog, Heiko, and Toshio Ohori. 2011. Grammaticalization in Japanese. In The Oxford Handbook of Grammaticalization. Edited by Heiko Narrog and Bernd Heine. Oxford: Oxford University Press, pp. 775-85.

Penny, Ralph. 2004. A History of the Spanish Language. Cambridge: Cambrigde University Press.

Pountain, Christopher J. 2000. Capitalization. In Historical Linguistics 1995: General Issues and Non-Germanic Languages. Edited by John Charles Smith and Delia Bentley. Amsterdam and Philadelphia: John Benjamins, vol. 1, pp. 295-309.

Rodríguez, Alexandre. 2006. Las Formas Verbales Subjuntivas. Su Reorganización Modo-Temporal. In Sintaxis Histórica de la Lengua Española. Mexico City: Fondo de Cultura Económica-Universidad Nacional Autónoma de México, vol. 1, pp. 95-240.

Smith, John C. 2011. Change and Continuity in Form-Function Relationships. In The Cambridge History of the Romance Languages. Edited by Martin Maiden, John Charles Smith and Adam Ledgeway. Cambridge: Cambridge University Press, vol. 1, pp. 268-317.

Traugot, Elizabeth Closs. 2008. Grammaticalization, constructions and the incremental development of language: Suggestions from the development of Degree Modifiers in English. In Variation, Selection, Development: Probing the Evolutionary Model of Language Change. Edited by Regine Eckardt, Gerhard Jäger and Tonjes Veenstra. Berlin: Mouton/De Gruyter, pp. 219-50.

Van de Velde, Freek, and Muriel Norde, eds. 2016. Exaptation: Taking Stock of a Controversial Notion in Linguistics. In Exaptation and Language Change. Amsterdam and Philadelphia: John Benjamins, pp. 1-35.

Wall, Albert, and Álvaro S. Octavio de Toledo y Huerta. 2016. Exploring and Recycling Topichood and the Evolution of Ibero-Romance Articles. In Exaptation and Language Change. Edited by Muriel Norde and Freek Van de Velde. Amsterdam and Philadelphia: John Benjamins, pp. 341-75.

(C) 2019 by the authors. Licensee MDPI, Basel, Switzerland. This article is an open access article distributed under the terms and conditions of the Creative Commons Attribution (CC BY) license (http://creativecommons.org/licenses/by/4.0/). 
Article

\title{
The Development of the Articles in Castilian: A Functional Approach
}

\author{
Christopher J. Pountain \\ School of Languages, Linguistics and Film, Queen Mary, University of London, London E1 4NS, UK; \\ c.j.pountain@qmul.ac.uk
}

Received: 14 March 2019; Accepted: 20 March 2019; Published: 28 March 2019

\begin{abstract}
The development of the definite and indefinite articles in Castilian may be regarded as an instance of capitalization or adfunctionalization, following partial exaptation of the Latin demonstrative ille, which involves progressive widening without significant loss of function, the rendering of overt distinctions which were previously covert through the contrast between definite article, indefinite article and the "zero" determiner, the creation of new expressive possibilities and the facilitating of further distinctions in the grammatical system in combination with other determiners (usage with possessives, demonstratives and tal is examined).
\end{abstract}

Keywords: refunctionalization; Castilian articles; definiteness; adfunctionalization; indefiniteness

\section{Introduction}

For several years, I have been investigating examples of a historical linguistic phenomenon, which in Pountain (2000a) I called capitalization, in which a linguistic element with one or more existing functions appears to be progressively exploited to acquire ever more functions. In the history of Castilian, I have studied the extension of the copular verb estar (Pountain 2000a), the reflexive (Pountain 2000b, 2000c, 2008) and the creation of the neo-neuter article lo (Pountain 2015). Without going into detailed summaries of these studies, I begin by calling attention to what may be considered the most salient characteristics of these three developments.

First, they involve a widening, without significant loss, of function, in the course of which the creation of a structural opposition is critical. Estar appears to invade the functional field of ser, while maintaining its original locative function, but although ser to a certain extent yields ground to estar, it could not be said that ser loses any of its own functionality, but rather that there is progressive competition between the two verbs. The same can be said of the reflexive, which does not cease to express literal reflexivity, even though it competes with the "etymological" passive voice (ser + past participle), which comes to have a reduced frequency and stylistic range. The most that can be said, therefore, in these cases, is that there is a change of markedness in the element which is drawn into such competition. The case of $l o$ is somewhat different, since the neuter gender as a morphological category disappeared completely in Castilian and the masculine definite article, which lo might have supplied (cf. several varieties of Catalan (Badía Margarit 1951, p. 287)) took the form el; the origin of this change might be seen as exaptation in the sense of Lass (1990) or refunctionalization in the sense of Smith (2011), according to which an element which is obsolescent comes to be used with a new value not necessarily related to its original value, which disappears. However, once lo is established as a determiner for an adjective, it thereafter broadens its functions without further loss.

Secondly, capitalization usually makes overt a distinction that was previously covert. The opposition between ser and estar with a past participle distinguishes a dynamic passive voice (La puerta es cerrada "the door is (being) closed/is (regularly) closed") from a stative passive voice (La puerta está cerrada "the door is (in a state of having been) closed"). The use of the reflexive as a passive voice 
allows the discrimination of a "middle" voice which does not envisage the participation of an agent. The reflexive passive La puerta se cerró "the door closed" in fact does not allow the statement of an agent at all: "La puerta se cerró por Miguel "the door was closed by Miguel" is unacceptable, and to express an agent Spanish uses the etymological passive La puerta fue cerrada por Miguel (unless, as is more frequent in speech, the passive is avoided altogether). The neo-neuter article (always appearing with an adjective, never with a noun) refers either to an absolute concept (lo referido $=($ todo) lo referido "(all) that has been referred to") or to a partitive concept (lo alto = la parte alta "the high part") by contrast with the nominal reference of an adjective used with other determiners (so el enfermo "the sick person", un joven "a young person").

Thirdly, capitalization creates new expressive possibilities. The extension of the opposition between ser and estar to adjectival complements has given rise to what are usually termed "subjective" uses of estar + adjective (so the "objective" Juan es amable "Juan is kind, a kind person" contrasts with Juan estuvo más amable que de costumbre "Juan was being kinder, behaving in a kinder way, than usual"). The reflexive has extended to both transitive and intransitive verbs, producing contrasts in meaning with the non-reflexive which are extremely difficult to describe because they are idiosyncratic to the verbs concerned, although there is no denying the reality of the distinction (such contrasts were studied in detail by (Moreira Rodríguez and Butt 1996)). Lo has developed a value of "extreme degree" which gives it what appears to be an adverbial function, there being no agreement between $l o$ and the adjective, which is normally required within a noun phrase, e.g., No sabes lo hermosa que es "You don't know how beautiful she is".

Fourthly, the consequences of capitalization may have a wider impact on the grammatical system. The establishment of the opposition between ser and estar with adjectives appears to have given rise to a parallel distinction in inceptive verbs (verbs of becoming): ponerse is restricted to contexts in which estar is permitted, so ponerse is used with triste (Juan se puso triste "Juan became sad" corresponds to Juan está triste "Juan is sad") while hacerse is used with viejo (mi padre se hizo viejo "my father became old" corresponds to mi padre es viejo "my father is old"). The favoring of the reflexive as a middle voice may have led to the lower frequency of the etymological passive as well as to the eventual demise of a potential competitor, the incipient indefinite pronoun hombre, which was amply attested in Old Castilian, and the comparative success of which can be observed in its French cognate on. The "extreme degree" function of lo competes with the older cuán deriving from Latin quam and finally overtakes it, since it is used not only with adjectives but with adverbs and whole noun phrases: Todos elogian lo gran actor que es "Everyone praises how great an actor he is" (Álvarez Menéndez 1970, p. 348), Me sorprende lo en su punto que está la sopa "It surprises me how absolutely ready the soup is" (Gutiérrez Rexach 1999, p. 44).

To a certain extent, capitalization corresponds to Smith (2011) notion of adfunctionalization. However, what is distinctive about capitalization is that it comprises a whole series of adfunctionalizations which are usually carried out over a considerable period of time. Thus, capitalization appears to correspond closely to the phenomenon described by Sapir within the venerable tradition (if not always completely honorable: see Pountain 2008) of the "genius" of a language:

All languages evince a curious instinct for the development of one or more particular grammatical processes at the expense of others, tending always to lose sight of any explicit functional value that the process may have had in the first instance, delighting, it would seem, in the sheer play of its means of expression. (Sapir 1921, p. 60)

This in turn recalls Voltaire's (Voltaire 1879) definition of génie de la langue: "son aptitude à dire de la manière la plus courte et la plus harmonieuse ce que les autres langages expriment moins heureusement" ("its capacity for saying in the shortest and most harmonious way what other languages express less felicitously"). The results of the cases of capitalization I have described so far may indeed be viewed as characteristic of Spanish and consequently a part of what might be called its "genius". They are accordingly features which non-native speakers are always very conscious, since they are the 
most problematic areas in learning and teaching the language, as well as in translation (as is apparent in many of the examples in this article).

\section{The Articles of Castilian}

The creation of the Castilian articles and their subsequent development seem to constitute another prima facie case of capitalization. Their growing frequency century by century is shown by the raw figures in Table 1:

Table 1. Raw occurrences and frequency per million words of the definite and indefinite articles in the Corpus del español (Davies 2002-2019) ${ }^{1}$.

\begin{tabular}{|c|r|r|r|r|}
\hline & el/la $\mathrm{N}$ & un/una $\mathrm{N}$ & los/las $\mathrm{N}$ & unos/unas $\mathrm{N}$ \\
\hline \multirow{2}{*}{$1200 \mathrm{~s}$} & 171,304 & 7702 & 85,752 & 518 \\
& $(25,508)$ & $(1147)$ & $(12,769)$ & $(77)$ \\
\hline \multirow{2}{*}{$1300 \mathrm{~s}$} & 69,593 & 714 & 28,521 & 30 \\
& $(26,069)$ & $(267)$ & $(10,684)$ & $(11)$ \\
\hline \multirow{2}{*}{$1400 \mathrm{~s}$} & 201,374 & 3992 & 86,532 & 118 \\
& $(24,674)$ & $(489)$ & $(10,603)$ & $(14)$ \\
\hline \multirow{2}{*}{$1500 \mathrm{~s}$} & 566,151 & 93,243 & 269,380 & 6362 \\
& $(33,236)$ & $(5474)$ & $(15,814)$ & $(373)$ \\
\hline \multirow{2}{*}{$1600 \mathrm{~s}$} & 445,108 & 83,587 & 167,940 & 3910 \\
& $(36,046)$ & $(6769)$ & $(13,600)$ & $(317)$ \\
\hline \multirow{2}{*}{$1700 \mathrm{~s}$} & 397,277 & 64,501 & 207,240 & 3149 \\
& $(40,470)$ & $(6571)$ & $(21,111)$ & $(321)$ \\
\hline \multirow{2}{*}{$1800 \mathrm{~s}$} & 885,140 & 226,731 & 361,058 & 5265 \\
& $(45,869)$ & $(11,749)$ & $(18,710)$ & $(273)$ \\
\hline \multirow{2}{*}{$1900 \mathrm{~s}$} & 975,746 & 300,905 & 395,102 & 9107 \\
& $(42,754)$ & $(13,185)$ & $(17,312)$ & $(399)$ \\
\hline
\end{tabular}

\subsection{Widening of Functions}

The articles have been the object of many valuable studies which I have no intention of replicating and on the results of which I am drawing; I pass immediately to a schematic chronology of their functions (Table 2). It can be seen that for each article there is a constant widening of function (adfunctionalization), against the background of a clear opposition between definite and indefinite article, although we must also take into account that the absence of a determiner (which I denote by $\varnothing$ in the examples) continues to be a possibility and also forms part of this functional contrast. Thus, two of the characteristics of capitalization identified in Section 1 are present.

Table 2. Functional extension of the Castilian articles (based chiefly on Company Concepción 1991, Garachana Camarero 2009 and Ortiz Ciscomani 2009).

\begin{tabular}{|c|c|c|}
\hline & Definite Article (ILLE) & Indefinite Article (UNUS) \\
\hline Latin & demonstrative: necessarily deictic (anaphoric) & number \\
\hline "Late" Latin & $\begin{array}{l}\text { anaphoric: not necessarily deictic definite } \\
\text { (attenuated demonstrative) }\end{array}$ & \\
\hline "Early" Castilian & extended anaphoric & \\
\hline 13th Cent. & $\begin{array}{l}\text { generic (subject human-referring nouns; unique } \\
\text { reference entities nominalizer }\end{array}$ & $\begin{array}{l}\text { "introductory": referential, specific (generic) } \\
\text { (plural unos/unas: see Table 5) }\end{array}$ \\
\hline 14th Cent. & extension of generic value & \\
\hline 15th Cent. & $\begin{array}{l}\text { abstract nouns } \\
\text { mass nouns }\end{array}$ & $\begin{array}{l}\text { not necessarily specific } \\
\text { "metaphorical" uses }\end{array}$ \\
\hline 16th Cent. & extension of nominalizing use & $\begin{array}{l}\text { proper nouns } \\
\text { unique reference entities } \\
\text { infinitives } \\
\text { extension of the plural }\end{array}$ \\
\hline
\end{tabular}

1 The reason for using the Corpus del español for this study is that, in spite of the many errors it contains, it has the enormous advantage of allowing searches by part of speech; without this facility, however rudimentary, obtaining statistics of this type would have been a practical impossibility. From the statistics in Table 1, it can be seen that: (a) the indefinite article always lags behind the definite article in terms of relative frequency; (b) the significant advance of the indefinite article takes place in the 16th century; and (c) the formal indefinite plural unos/unas is comparatively infrequent. 
We now look more closely at the development of these functions.

\subsubsection{The Definite Article}

The generally accepted explanation of the evolution of the Romance definite article (see, for example, Harris 1978, pp. 70-72) suggests that it begins with what may be considered an exaptation or partial refunctionalization of one of the Latin demonstratives (most widely ille), in conjunction with its substitution as a demonstrative by a reinforced form (*accu ille in the case of Castilian). The impression we have of the use of ille in Late Latin (especially in the Peregrinatio Egeriae, for which the data are well known) is of a change of markedness, evidence for which is its greater frequency. The starting point for the extension of functions which is characteristic of capitalization is its anaphoric value, and it is in an "extended" anaphoricity that we can find the key to its subsequent expansion. ${ }^{2}$ Its use with unique reference entities ( $e l$ sol "sun", el rey "king", etc.) may be seen as a cultural anaphoricity (it would be inappropriate to speak of el rey "the king" in a community in which there was no king, or in which there was more than one king). Inalienable possession (typically with parts of the body) may also be considered a type of anaphoricity, in which the possessed element (la mano "hand" in (1a), el pie "foot" in (1b)) is necessarily associated with either the subject of the verb (1a) or with an indirect object (1b) (Juan):

\begin{tabular}{|c|c|c|c|c|c|c|}
\hline \multirow[t]{2}{*}{ (1) $\quad a}$. & $\begin{array}{l}\text { Juan } \\
\text { Juan }\end{array}$ & $\begin{array}{l}\text { levantó } \\
\text { raised }\end{array}$ & $\frac{l a}{\text { DEF.ART }}$ & $\frac{\text { mano }}{\text { hand }}$ & & \\
\hline & \multicolumn{6}{|c|}{ "Juan raised his hand" } \\
\hline b. & A & Juan & le & duele & $\underline{e l}$ & pie \\
\hline & To & Juan & 3SG.IND.OBJ & hurts & DEF.ART & foot \\
\hline
\end{tabular}

It is also interesting, incidentally, that the notion of what is "inalienable" seems to have undergone greater extension in Castilian than in some other Romance languages: Butt and Benjamin (2013, p. 29) pointed out that, while a sentence such as (2) is usual in Castilian, it has no parallel in French, for example.

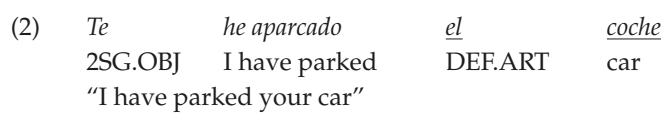

What may be regarded as the strict function of definiteness was probably associated with the use of the demonstrative with the antecedent of a defining relative clause, a modern Castilian example of which is given in (3): there are numerous examples of such a function in Late Latin (4).

\begin{tabular}{|c|c|c|c|c|c|c|c|c|}
\hline \multirow[t]{3}{*}{ (3) } & $\underline{E l}$ & hombre & que & confundió & $a$ & $s u$ & mujer & con \\
\hline & un & sombrero & & & & & & \\
\hline & $\begin{array}{l}\text { DEF.ART } \\
\text { a }\end{array}$ & $\begin{array}{l}\text { man } \\
\text { hat }\end{array}$ & REL & confused & OBJ & his & wife & with \\
\hline
\end{tabular}

(4) Et quoniam nobis iter sic erat, ut per valle illa media qua tenditur per longum, iremus [...]

(Peregrinatio Egeriae, 43,4)

"And since our way was such that we went through the/that middle valley which stretched out ahead $[\ldots]^{\prime \prime}$

2 For what may be regarded as a pragmatically oriented account of such a change in markedness between deixis and anaphora related to the emergence of the Romance definite article, see Kabatek (2012, pp. 82-83). 
This function is in fact closely related to that of anaphoricity, since anaphoricity may be construed as presupposing an understood defining relative clause such as "which we have already mentioned". Indeed, it can be seen that in (4) the demonstrative fulfils both of these functions simultaneously: illa appears with the antecedent (valle) of a relative clause (qua tenditur per longum), but this noun has been previously mentioned in the discourse and so the reference is also anaphoric.

The definite function also includes nouns that are defined by adjectives ( $5 a$ ) or adjectival phrases $(5 b)$, which can be considered as reduced relatives.

$\begin{array}{lllll}\text { (5) a. } & \text { el } & \text { libro } & \text { amarillo } \\ & \text { DEF.ART } & \text { book } & \text { yellow } & \\ & \text { "the yellow book" (= "The book which is yellow") } & \\ \text { b. } & \text { el } & \text { tren } & \text { de } & \text { Málaga } \\ & \text { DEF.ART } & \text { train } & \text { of } & \text { Málaga } \\ & & \end{array}$

The use of the definite article to indicate the problematic notion of genericness must be considered separately. Genericness is almost certainly also related pragmatically to anaphoricity since it depends on shared cultural knowledge of what can constitute a class (or, rather, the totality of a class). Nonetheless, the notions are different. With nouns pragmatically understandable as denoting a generic concept, there is potential ambiguity between a generic and anaphoric reference of the definite article in Castilian, which only the discourse context will resolve: in Me gusta el vino, el vino could be understood as wither anaphoric ("the wine", the wine already mentioned) or generic ("wine", wine in general) (see Butt and Benjamin 2013, p. 31): I reached similar conclusions concerning the multiple values of the reflexive in Pountain (2000c). Genericness can be expressed by both the plural (6a) and, less freely (see Chesterman 1991, pp. 32-39), by the singular (6b), although the latter usage is actually attested as early as the 13th century (6c):

(6) a. Los ingleses [PL.] tienen fama de ser muy flemáticos

"English people have the reputation of being very phlegmatic"

b. El cuclillo [SG.] pone sus huevos en nidos ajenos

"The cuckoo lays its eggs in other birds' nests"

c. [...] mas cruel E mas dannoso que es el lobo [SG.] en la grey de las oueias en la noche. (CdE:

Alfonso X, Estoria de España I, S.XIII)

"[...] more cruel and damaging than is the wolf in the flock of sheep at night"

We may also regard the use of the definite article with abstract nouns (la vergüenza "shame", la belleza "beauty") and mass nouns (la leche "milk", el hielo "ice") as essentially generic, since these nouns denote general concepts. As can be seen in Table 2, the generic values of the definite article appear after its anaphoric values; generally speaking, it is in these various generic values that the Romance definite article and the English definite article do not correspond (the only point in common is the generic use of the singular (6b) and (6c), which is in fact the first such usage to be attested with any regularity).

The development of these essentially pragmatic functions is perhaps the most significant factor in the process of capitalization or adfunctionalization of ILLE. However, ILLE also came to have a range of nominalizing functions (Company Concepción 1991, p. 418): it is used with adjectives (7a), infinitives (7b) and, rather later, with clausal complements (7c) (the first such example I have found in CdE is from the 16th century $(7 \mathrm{~d}))$ : 


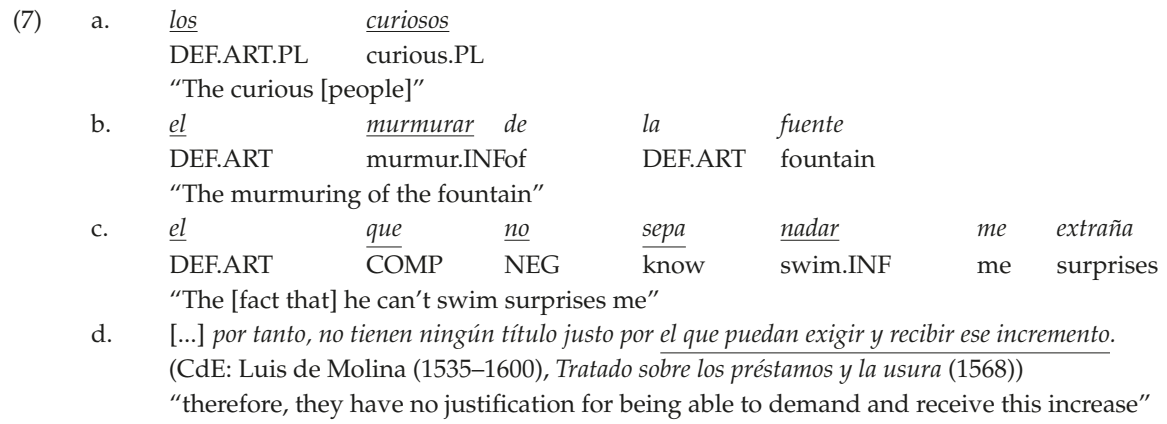

Finally, it should be noted that there is apparently a good deal of idiosyncrasy (at least from a comparative point of view: see Butt and Benjamin 2013, pp. 28-29) in the subsequent use of the definite article in modern Castilian, especially in prepositional phrases: consider, for example, the lack of parallelism between en la práctica "in practice" but en Ø teoría "in theory" and the apparent semantic contrast between en la cama y en Ø cama "in bed" (the latter is often said to imply illness).

Similarly, many uses of the definite article in modern Castilian that depend on particular syntactic contexts are also essentially idiosyncratic and liable to variation. Such idiosyncrasy can be observed with names of languages (habla Ø francés "(s)he speaks French" but habla bien el francés "(s)he speaks French well"), days of the week (a partir del domingo "from Sunday" but hoy es $\varnothing$ domingo "today is Sunday") and names of countries (Ø Francia "France" but la India "India").

\subsubsection{The Indefinite Article}

The history of the indefinite article is fundamentally different from that of the definite article, since, while Lat. unus "one" underwent a significant expansion of functions, it never lost its numerical value: it is therefore inappropriate to speak of exaptation in this case, and its extension can be considered a case of adfunctionalization pure and simple. Until the 14th century, it maintained a specific and referential function, which was in accordance with its value as a numeral. It was only in the 15th century that the derivative of unus began to be used to signal new information that did not necessarily have a specific reference. In Golden Age Spanish, its extension to what is sometimes called (Garachana Camarero 2009, p. 401) a "metaphorical" value can be observed (8a), which included use with proper nouns (8b): in Table 3, as a simple but eloquent indication of this development, I give the figures derived from the CdE for the string es un (a) $\mathrm{N}$.

(8) a. Él es un ángel en la tierra, cierto,

$\mathrm{y}$ vive entre nosotros de manera,

como en las soledades del desierto (CdE: Miguel de Cervantes Saavedra (1547-1616), El rufián dichoso)

"He is an angel on earth, for sure, and lives amongst us as in the solitude of the desert"

b. Fijaos qué fuerza tiene la razón que, después de conocerla, sois un Cicerón o un San Pablo.

(CdE: Jerónimo Jiménez de Urrea (1510-1574), Diálogo de la verdadera honra militar (1542))

"Consider what force reason has, for after becoming aware of it, you are a Cicero or a Saint Paul"

In addition, in the 16th century, the indefinite article extended to many of the contexts in which the definite article could already be used: it appears with unique reference entities (again with a "metaphorical" meaning (9a)), and as a nominalizer with infinitives and adjectives (9b-c). 
(9) a. su hermosura y gracias extremadas son hoy en día un sol que alumbra el mundo (CdE: Jorge de Montemayor (1520-1561), Los siete libros de la Diana, 1540)

"Her beauty and extreme graces are today a sun which gives light to the world"

b. si restituir es un volver cuanto se tomó y dañó [...] (CdE: Tomás de Mercado (?-1575), Summa de tratos y contratos, 1545)

"If making restitution is (a) giving back of what was taken and damaged [...]"

c. $\quad$ un triste que siempre llora (CdE: José de Valdivielso (1560-1638), La serrana de Plasencia, 1599)

"a sad person who is always crying"

Indicative statistics are difficult to provide, however: in particular, it did not prove practical to isolate instances of $u n(a)$ followed by an adjective without an accompanying noun. Table 4 gives the figures for the string $u n$ followed by an infinitive: while these inevitably include some lexicalized infinitives, the general direction of change is very clear.

Table 3. The string es un(a) $\mathrm{N}$ in CdE (raw figures and frequency per million words).

\begin{tabular}{|c|c|}
\hline & es un $(a) \mathrm{N}$ \\
\hline $1200 \mathrm{~s}$ & $90(13.40)$ \\
\hline $1300 \mathrm{~s}$ & $10(3.75)$ \\
\hline $1400 \mathrm{~s}$ & $61(7.47)$ \\
\hline $1500 \mathrm{~s}$ & $1936(113.65)$ \\
\hline $1600 \mathrm{~s}$ & $1649(133.54)$ \\
\hline $1700 \mathrm{~s}$ & $2526(257.32)$ \\
\hline $1800 \mathrm{~s}$ & $7665(397.21)$ \\
\hline $1900 \mathrm{~s}$ & $17,458(764.96)$ \\
\hline
\end{tabular}

Table 4. $u n$ + infinitive in CdE (raw figures and frequency per million words).

\begin{tabular}{|r|r|}
\hline & un + infinitive \\
\hline $1200 \mathrm{~s}$ & $11(1.64)$ \\
\hline $1300 \mathrm{~s}$ & $2(0.75)$ \\
\hline $1400 \mathrm{~s}$ & $15(1.84)$ \\
\hline $1500 \mathrm{~s}$ & $240(14.09)$ \\
\hline $1600 \mathrm{~s}$ & $98(7.94)$ \\
\hline $1700 \mathrm{~s}$ & $46(4.69)$ \\
\hline $1800 \mathrm{~s}$ & $183(9.48)$ \\
\hline $1900 \mathrm{~s}$ & $260(11.39$ \\
\hline
\end{tabular}

What is most striking in the evolution of the indefinite article, partly because it confirms its independence from its original numerical value and partly because it is a particularly prominent feature of Castilian (though the phenomenon is attested both formerly and currently in other Romance varieties, see Carlier (2001, pp. 81-84) for Old French, Ledgeway (2011, p. 410) and Vincent (2017)), is the appearance of the plural unos/as, which represents another important stage in the capitalization of unus, and, indeed, in its grammaticalization as an article. Table 5 shows a veritable explosion of this plural in the 16th century, although its modern use appears to be attested as early as the 13th century (10a). The majority of examples prior to the 16th century, however, seem to be of unos/as $\mathrm{N}$ in opposition with otros/as $\mathrm{N}$ (10b); unos/as could also appear with the definite article, especially if it marked anaphoric reference (10c). 
Table 5. Appearance of unos/unas $\mathrm{N}$ in CdE (raw figures).

\begin{tabular}{|r|r|r|r|}
\hline & unos/unas $\mathrm{N}$ & algunos/as $\mathrm{N}$ & unos/unas $\mathrm{N}$ as $\%$ of total \\
\hline $1200 \mathrm{~s}$ & 326 & 1045 & $23.78 \%$ \\
\hline $1300 \mathrm{~s}$ & 16 & 626 & $2.49 \%$ \\
\hline $1400 \mathrm{~s}$ & 85 & 4119 & $2.02 \%$ \\
\hline $1500 \mathrm{~s}$ & 4916 & 8984 & $35.37 \%$ \\
\hline $1600 \mathrm{~s}$ & 2875 & 4815 & $37.39 \%$ \\
\hline $1700 \mathrm{~s}$ & 2213 & 5944 & $27.13 \%$ \\
\hline $1800 \mathrm{~s}$ & 4002 & 7566 & $34.60 \%$ \\
\hline $1900 \mathrm{~s}$ & 6773 & 8568 & $44.15 \%$ \\
\hline
\end{tabular}

t sample of 1000 nouns.

(10) a. Esse anno priso Autuman Rey de los Alaraues unas tierras que son llamadas por sus nombres [...] (CdE: Alfonso X, Estoria de España I, 13th cent.)

"That year Autuman King of the Arabs captured lands which are called [...]"

b. Unas tierras dan vino, en otras dan dineros (CdE: Gonzalo de Berceo, La vida de San Millán de la Cogolla, 466a, 13th cent.).

"Some lands yield wine, in others they give money"

c. Et los unos panes auien nombre sacerdotales./Los otros panes leuiticos. (CdE: Alfonso X, General estoria $I, 13$ th cent.).

"And one kind of bread was called priestly [and] the other kind of bread [was called] Levitical."

Table 5 also gives the figures for algunos/as $\mathrm{N}$ and the percentage of unos/unas $\mathrm{N}$ of the combined total of unos/unas $\mathrm{N}$ and algunos/algunas $\mathrm{N}$, from which the more or less constant effect of unos/unas $\mathrm{N}$ and its steady competition with algunos/algunas from the 16th century onwards can be seen.

\subsection{Representation of Covert Distinctions}

Having established the general lines of the expansion of the functions of the Castilian articles, we now consider the second characteristic of capitalization, the extent to which the introduction of the articles made overt distinctions which were previously covert.

The most obvious distinction is that between the anaphoric value of the definite article referring to an established discourse topic and the non-anaphoric value of the indefinite article introducing a new topic, which is, moreover, the most fundamental and longest established general functional contrast between the two articles. A clear early example is (11), where una niña is used to mark the first mention of the little girl in the discourse; once introduced, she is then referred to anaphorically as la niña:

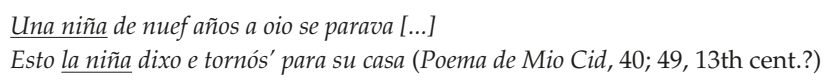

Una niña de nuef años a oio se parava [...]

Esto la niña dixo e tornós' para su casa (Poema de Mio Cid, 40; 49, 13th cent.?)

"A little nine-year-old girl appeared before their eyes [...]

This is what the girl said, and [then] she went back to her home."

This does not mean to say, of course, that in the absence of articles Latin had no recourse for expressing anaphoricity in the case of necessity: we have seen that this was one of the functions of the Latin demonstratives, and that the "weak" demonstrative IS, for which in a sense ille was a substitute (see André and Fruyt 2012), also discharged this function. Anaphoricity is also dependent on word order: Lyons (1968, p. 392) called attention to the fact that the topic of a sentence is usually "definite", whether or not such definiteness is explicitly marked. He commented on the Latin sentences in (12) that in (12a) and (12b) the topic is determined by word order, so that the expected value of liber "book" in (12a), where it is in final position, is that it is not the topic (and non-anaphoric), while in (12b), where it occurs initially, it is the topic (and anaphoric). 


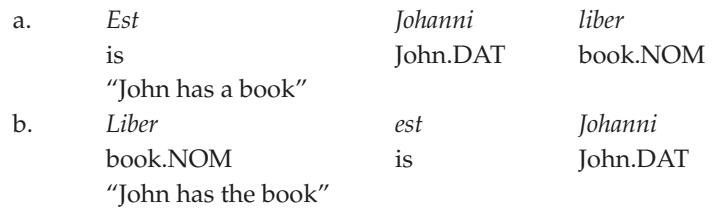

(See also (Bauer 2009) on the relation between case and definiteness in Latin.) The article in fact very often seems to be a superfluous element, since it expresses functions that can very well be deduced from the discourse context. It is important to stress this, because within Romance linguistics there is a long tradition that associates the development of the definite article with the supposed typological passage from synthesis (Latin) to analysis (the Romance languages). Alvarez Martínez (1986, p. 18), quoting Abel (1971, p. 1), went so far as to say that the creation of the article is a central problem of Romance linguistics and indeed of general linguistics because it allows synthetic languages to be distinguished from analytic languages. Harris (1978, p. 70) similarly opined that the evolution of the articles as markers of specificity is "in accordance with the general tendency towards explicitness and towards preposed category marking". Some scholars have accordingly been tempted to wonder how Latin functioned without an article: Meillet and Vendryes (1966, p. 591) said that the absence of the article makes itself felt ["se fait sentir"] in cases such as (13):

(13) Frigida pugnabant calidis, humentia siccis

mollia cum duris, sine pondere habentia pondus (Ovid, Met., I, 19-20)

"Things which were cold fought against things which were hot, things which were wet against things which were dry, things which were soft against things which were hard, things which were of no weight with things which were weighty"

However, in reality, what, if anything, was lacking in Latin were adjectives corresponding to the notions of sine pondere and habentia pondus and there is actually no difficulty at all in understanding what Ovid wanted to express. As Pinkster points out:

In spite of the absence of the definite and indefinite article, in the Latin texts it is in a very large number of cases clear whether an NP is definite or indefinite. (Pinkster 1990, pp. 93-94)

Pinkster mentioned unique reference entities, proper nouns, inalienable possession and the anaphoric reference of a second mention noun as cases in which the presence of an article is in fact superfluous, and in similar vein Chesterman (1991, p. 4) quoted the opinion of Gardiner (1932, p. 47) according to whom the article "is mere useless ballast".

\subsection{The Creation of New Expressive Possibilities}

The view that the article is a redundant category is worth pursuing a little further in relation to capitalization, since it often seems that capitalization is concerned with the creation of categories that from a functional point of view can to a certain extent be regarded as superfluous. In the cases of capitalization I have already analyzed (the rise of the copula estar, the reflexive as an exponent of the middle voice, and the introduction of a neo-neuter article), the distinctions which these developments appear to make explicit, and the new expressive possibilities they create, are very far from being universal, and this is precisely why they become distinctive features of Castilian, giving it an individual "cut". However, while a similar case might be made in a broad comparison between languages with articles and languages without articles, a definite article deriving from a demonstrative has been perceived as a common enough feature for Greenberg (1978) to establish his "cycle of definiteness", and even for this evolutionary pathway to be regarded by some as universal (Faingold 2003, p. 39). It seems clear that Castilian is broadly at Stage II of the Greenberg cycle (the article is largely grammaticalized and determined by the syntactic context, but there is some residual contrast between the presence and absence of the article) and has not yet reached Stage III (the article is merely a nominal marker with no distinctive function). While, then, there is a degree of redundancy in the article at Stage II, there is still 
opportunity for its exploitation to create new expressive possibilities, as I show below. It is precisely at this point that the differences between closely related languages emerge: Harris (1980, p. 82) concluded that French is also at Stage II of the Greenberg cycle; however, French has clearly moved further than Castilian towards Stage III, and a number of the new expressive possibilities identified in this section for Castilian are simply unavailable to French.

We turn, therefore, to the third characteristic of capitalization: that it appears to allow new expressive possibilities or more "felicitous" or economical modes of expression. We should again remember that, as far as the articles are concerned, we do not have a binary distinction between definite and indefinite, but a tripartite distinction among definite, indefinite and lack of determination or zero article, a possibility that has always been available in Castilian (cf. Kabatek 2012, p. 85).

The area in which one can put the most effective argument for the introduction of new expressive possibilities in Castilian by comparison with Latin and indeed by comparison with other languages is not in the opposition between definite and indefinite article as such but in the oppositions definite article/zero article and indefinite article/zero article, at a fairly advanced stage of the development of the articles. For example, in the complements of the copular verb ser "to be", the absence of the article usually denotes literal membership of a class or category (14a), while the presence of the indefinite article implies a value judgement (the so-called "metaphorical" value of the indefinite article) (14b). These sentences are difficult to gloss in English except by lengthy paraphrase, since in English the indefinite article is always obligatorily present ("Juan is a politician"); to render the full sense of (14b) a different verb must be used ("John behaves like a politician") or an adjective introduced ("John is a real politician"). While (14a) is an objective statement, (14b) is a value-judgement, i.e. (14b) is not literally true, and (14b) does not imply (14a).

(14) a. Juan es $\varnothing$ político

b. Juan es $\overline{\text { un politico }}$

Another contrastive context for the indefinite and zero articles is in the complements of verbs such as tener "to have" and comprar "to buy": here the presence of the indefinite article (15a) is unmarked because it represents the normal pragmatic expectation ("Do you know that our friend Juan has bought a car?"). The implication of (15b), on the other hand, is once again more difficult to render in English. Alonso (1933, p. 198) paraphrased it by saying that it is the category to which the object bought by Juan belongs that is at the forefront of the speaker's mind, and represents a change in status; for this, an appropriate English gloss is "Do you know that John has become a car owner?"

(15) a. ¿Sabes que nuestro amigo Juan ha comprado un automóvil? Alonso (1933, p. 198)

b. ¿Sabes que nuestro amigo Juan ha comprado Ø automóvil?

Examples similar to (15b) can be identified from quite early in the Castilian textual record: Company Concepción (1991, pp. 406-7) called attention to contrasts between the definite and zero articles such as those in (16). (16a), similar to (15a), has a straightforward objective reading; the only complication in giving an English gloss is that we should understand the sword (and, for that matter, the neck of the victim) as inalienably possessed. (16b), similar to (15b), has a different nuance that is not fully expressed by the simple English gloss given: it refers to the moment at which the Cid became a knight and hence implies his symbolic taking up of his sword, a change in his status; it is a formulaic expression in this epic.

(16) a. dio muy grant ferida con el espada en el pescuezo (Primera Crónica General, 118a7, 13th cent.)

"He dealt a very great blow with [his] sword on [his] neck"

b. $\quad$ en buen ora cinxiestes $\varnothing$ espada (Poema de Mio Cid, 41, 13th cent.?)

"In a good hour you girded on [your] sword"

A final area in which we may speak of the creation of a new expressive possibility is in the opposition between the plural indefinite article unos/unas and the zero article. Unos/unas individualizes nouns which appear in the plural: unas gafas denotes a single entity ("a pair of spectacles"), unas 
vacaciones a single instance ("a holiday") (De Bruyne 1995, p. 62): such a value is also attested in Old and Middle French and in Occitan (Ledgeway 2011, p. 410). Butt and Benjamin (2013, p. 47) noted that unos/unas "can add a modest note", perhaps because it implies a limited quantity, not just the vague "some", as in (17).

Mira estas fotos-son unas vistas tomadas en Guadalajara (Butt and Benjamin 2013, p. 47)

"Look at these photos: they are [(just) a few] shots taken in Guadalajara"

With figures, unos/unas indicates an approximate quantity:

(18) a. $\varnothing$ doscientas persona

"two hundred people [exactly]"

b. unas doscientas personas

and

"about two hundred people"

with percentages there is a similar opposition between the definite and indefinite articles:

(19) a. el $20 \%$ de los alumnos

" $20 \%$ [exactly] of the students"

b. un $20 \%$ de los alumnos

"[approximately] $20 \%$ of the students"

\subsection{Impact on the Grammatical System}

Although within the grammatical tradition articles are usually isolated as a category apart, it is clear that they are part of an extensive system of nominal premodifiers, or determiners, with which they are closely related. The articles, then, could not in themselves have been a motivating factor in the creation of the class of determiners; it is more probable that they became part of an already existing system, even though they reinforced and extended it; this system would continue to extend progressively with the introduction of ever more elements. As Tables 6-8 show, "introductory" cierto "(a) certain", indefinite algún "some" and anaphoric dicho "the aforementioned" have been embedded in the language for a long period, while introductory determinado "(a) certain", indefinite varios "several" and anaphoric mencionado, referido and citado "the aforementioned" are of more recent date (the English glosses give simple semantic equivalences; they are not necessarily equivalent in register or frequency of occurrence). Once again, such figures are not very rigorous, but they do indicate the general lines of development.

Table 6. "Introductory" determiners in Castilian in CdE (raw figures).

\begin{tabular}{|r|r|r|}
\hline & cierto/a/os/as N + & determinada/os/as $\mathrm{N}$ \\
\hline $1200 \mathrm{~s}$ & 303 & 0 \\
\hline $1300 \mathrm{~s}$ & 289 & 0 \\
\hline $1400 \mathrm{~s}$ & 1384 & 12 \\
\hline $1500 \mathrm{~s}$ & 3516 & 48 \\
\hline $1600 \mathrm{~s}$ & 1068 & 14 \\
\hline $1700 \mathrm{~s}$ & 1658 & 189 \\
\hline $1800 \mathrm{~s}$ & 6247 & 269 \\
\hline $1900 \mathrm{~s}$ & 5138 & 1062 \\
\hline
\end{tabular}

† sample of 1000 nouns.

The interaction of the articles with other determiners is indeed one of the most interesting aspects of the history of the Romance article from the point of view of capitalization, since it creates even more expressive possibilities within this wider system, as I show below. 
Table 7. Indefinite determiners in Castilian in CdE (raw figures).

\begin{tabular}{|r|r|r|r|}
\hline & algún/alguna $\mathrm{N}+$ & algunos/algunas $\mathrm{N}$ & varios/as $\mathrm{N}$ \\
\hline $1200 \mathrm{~s}$ & 4303 & 1045 & 4 \\
\hline $1300 \mathrm{~s}$ & 1097 & 626 & 7 \\
\hline $1400 \mathrm{~s}$ & 4348 & 4119 & 30 \\
\hline $1500 \mathrm{~s}$ & 10,261 & 8984 & 844 \\
\hline $1600 \mathrm{~s}$ & 5555 & 4815 & 931 \\
\hline $1700 \mathrm{~s}$ & 7399 & 5944 & 3277 \\
\hline $1800 \mathrm{~s}$ & 7999 & 7566 & 2697 \\
\hline $1900 \mathrm{~s}$ & 6523 & 8568 & 6702 \\
\hline \multicolumn{4}{|c}{+ sample of 1000 nouns. } \\
\hline
\end{tabular}

Table 8. Anaphoric determiners in Castilian in CdE (raw figures).

\begin{tabular}{|r|r|r|r|r|}
\hline & dicha/os/as $\mathrm{\dagger}$ & citada/os/as N & referida/os/as N & mencionada/os/as N \\
\hline $1200 \mathrm{~s}$ & 156 & 0 & 0 & 0 \\
\hline $1300 \mathrm{~s}$ & 247 & 0 & 0 & 0 \\
\hline $1400 \mathrm{~s}$ & 4587 & 0 & 0 & 0 \\
\hline $1500 \mathrm{~s}$ & 3459 & 4 & 24 & 2 \\
\hline $1600 \mathrm{~s}$ & 834 & 2 & 94 & 0 \\
\hline $1700 \mathrm{~s}$ & 2922 & 190 & 149 & 72 \\
\hline $1800 \mathrm{~s}$ & 2411 & 166 & 109 & 92 \\
\hline $1900 \mathrm{~s}$ & 1013 & 114 & 44 & 66 \\
\hline \multicolumn{5}{|c}{ t sample of 1000 nouns. } \\
\hline
\end{tabular}

\subsubsection{With Demonstratives}

The fundamental impossibility of combining an article with a demonstrative in both Spanish and English (*el este libro/*the this book; *un este libro/*a this book) is easily understood. The definite article and the demonstrative duplicate similar anaphoric and deictic functions, while the indefinite article and the demonstrative are incompatible in terms of these functions. Nonetheless, in relatively recent times, the sequence $e l+\mathrm{N}+$ demonstrative has been exploited in Spanish to express a new ironical nuance. It is difficult to fix the origins of this possibility with any certainty, since it seems that the construction originates in the informal spoken language which is not represented with any regularity in the written texts on which the corpora are based, but examples can be found in CdE for the 19th century: in (20) I give one of these with a deliberately extended context so that its meaning can be more fully appreciated:

(20) Y esto no quiere decir, claro está, que se deba abandonar el lenguaje y el estilo y escribir con desatino. Pero de ello a convertirse en esclavo de un molde, vaya mucha diferencia. En mi sentir, el escollo este del molde viene, sobre todo, del deseo de originalidad. (CdE: Amado Nervo (1870-1919), La lengua y la literatura (1894)).

"And clearly this does not mean to say that language and style should be abandoned and that one should write loosely. But there is a big difference between doing that and becoming a slave to a particular model. In my view, this [terrible] obstacle of the model comes chiefly from the desire for originality."

[The author is criticizing the idea of a model in writing.]

\subsubsection{With Possessives}

In Old Castilian, both articles could combine with the possessive. As can be seen in Tables 9-11, $e l+$ POSS $+\mathrm{N}$ has always been a minority variant, with no appreciable semantic difference from $\varnothing+$ POSS $+\mathrm{N}$; but $u n+$ POSS $+\mathrm{N}(21 \mathrm{a})$, even if it did not exactly constitute a new expressive possibility, is quite different in meaning from $(e l)+$ POSS $+\mathrm{N}$, and was yet another more economical ("felicitous") 
means of expressing the notion of "one of" + POSS N. From the 16th century onwards, this construction is replaced increasingly by $u n+N+$ POSS (21b), and another possibility for expressing the same notion, though a minority variant, as can be seen in Table 11, is the analytical formula uno/a de + POSS $+\mathrm{N}(21 \mathrm{c})$.

Table 9. $\varnothing+$ POSS $+\mathrm{N}$ in CdE (raw occurrences)

\begin{tabular}{|r|r|}
\hline & $(\varnothing)$ POSS N + +† \\
\hline $1200 \mathrm{~s}$ & 44,388 \\
\hline $1300 \mathrm{~s}$ & 16,471 \\
\hline $1400 \mathrm{~s}$ & 42,865 \\
\hline $1500 \mathrm{~s}$ & 158,796 \\
\hline $1600 \mathrm{~s}$ & 150,815 \\
\hline $1700 \mathrm{~s}$ & 71,314 \\
\hline $1800 \mathrm{~s}$ & 189,395 \\
\hline $1900 \mathrm{~s}$ & 95,535 \\
\hline
\end{tabular}

+ Based on a sample of 1000 nouns. +† It would be very difficult to calculate the frequency of $\varnothing+P O S S+N$, since it is impossible to isolate just this sequence in a search. The figure given here is for the raw occurrences of POSS $+\mathrm{N}$ and so includes all instances of preposed determiners; even so, it is clear that $\varnothing+\mathrm{POSS}+\mathrm{N}$ has always been the majority variant, as may be verified by subtracting from these figures the total of the figures in the tables for definite and indefinite article and demonstrative + POSS.).

Table 10. Definite article + POSS + N in CdE (raw occurrences).

\begin{tabular}{|r|r|r|}
\hline & el/la POSS N & los/las POSS N † \\
\hline $1200 s$ & 2360 & 2077 \\
\hline $1300 s$ & 806 & 838 \\
\hline $1400 \mathrm{~s}$ & 1186 & 1502 \\
\hline $1500 \mathrm{~s}$ & 285 & 293 \\
\hline $1600 \mathrm{~s}$ & 42 & 35 \\
\hline $1700 \mathrm{~s}$ & 96 & 692 \\
\hline $1800 \mathrm{~s}$ & 55 & 56 \\
\hline $1900 \mathrm{~s}$ & 9 & 7 \\
\hline \multicolumn{3}{|c|}{ t Based on a sample of 1000 nouns. } \\
\hline
\end{tabular}

Table 11. Indefinite article + POSS $+\mathrm{N}$ in CdE (raw occurrences).

\begin{tabular}{|r|r|r|r|r|r|r|}
\hline & $\begin{array}{l}\text { un/una } \\
\text { POSS N }\end{array}$ & $\begin{array}{l}\text { un/una } \\
\text { N POSS }\end{array}$ & $\begin{array}{l}\text { uno/una de } \\
\text { POSS Nt }\end{array}$ & $\begin{array}{l}\text { unos/unas } \\
\text { POSS N }\end{array}$ & $\begin{array}{l}\text { unos/unas } \\
\text { N POSS }\end{array}$ & $\begin{array}{l}\text { unos/unas de } \\
\text { POSS N }\end{array}$ \\
\hline 1200 s & 74 & 5 & 18 & 8 & 0 & 7 \\
\hline 1300 s & 3 & 1 & 7 & 1 & 0 & 0 \\
\hline 1400 s & 15 & 11 & 6 & 0 & 1 & 0 \\
\hline $1500 \mathrm{~s}$ & 349 & 965 & 230 & 7 & 24 & 2 \\
\hline $1600 \mathrm{~s}$ & 88 & 772 & 174 & 7 & 28 & 0 \\
\hline $1700 \mathrm{~s}$ & 27 & 364 & 216 & 6 & 9 & 0 \\
\hline $1800 \mathrm{~s}$ & 100 & 581 & 799 & 6 & 15 & 7 \\
\hline $1900 \mathrm{~s}$ & 13 & 403 & 1094 & 0 & 15 & 5 \\
\hline
\end{tabular}

(21) a. tiene preso un mi hermano (CdE: Diego Ortúñez de Calahorra, Espejo de príncipes y cavalleros. Libro II (s.XVI))

"he holds one of my brothers prisoner"

b. Por gran ventura hallé en ella tres hijos de un hermano mío, de quien yo no había sabido en muchos años (CdE: Pedro Fernandes de Queiros (1565-1615), Historia del descubrimiento de las regiones austriales (1590))

"By good fortune I found there three children of one of my brothers, of whom I had heard nothing for many years."

c. $\quad y$ topó en el camino uno de sus compañeros, que también iba huyendo (CdE: José de Acosta (1539-1600), Cartas (1570)).

"and he met one of his companions on the road, who was also fleeing" 
Demonstratives and quantifiers are also used in the same sense and follow a similar evolutionary trajectory, although at different paces (statistics for algún and (aqu)este are given in Tables 12 and 13).

Table 12. Algún, etc. + POSS $+\mathrm{N}$ in CdE (raw occurrences).

\begin{tabular}{|r|r|r|}
\hline & algún, etc., POSS N & algún, etc. N POSS \\
\hline $1200 s$ & 53 & 19 \\
\hline $1300 \mathrm{~s}$ & 10 & 1 \\
\hline $1400 \mathrm{~s}$ & 30 & 18 \\
\hline $1500 \mathrm{~s}$ & 26 & 116 \\
\hline $1600 \mathrm{~s}$ & 15 & 92 \\
\hline $1700 \mathrm{~s}$ & 16 & 98 \\
\hline $1800 \mathrm{~s}$ & 10 & 51 \\
\hline $1900 \mathrm{~s}$ & 4 & 17 \\
\hline
\end{tabular}

Table 13. Demonstrative + POSS $+\mathrm{N}$ in CdE (raw occurrences).

\begin{tabular}{|r|r|r|}
\hline & (aqu)este, etc. POSS N & (aqu)este, etc. N POSS \\
\hline $1200 s$ & 383 & 7 \\
\hline $1300 s$ & 126 & 2 \\
\hline $1400 s$ & 292 & 6 \\
\hline $1500 s$ & 889 & 144 \\
\hline $1600 s$ & 256 & 99 \\
\hline $1700 s$ & 268 & 78 \\
\hline $1800 s$ & 246 & 123 \\
\hline $1900 s$ & 31 & 50 \\
\hline
\end{tabular}

+ Based on a sample of 1000 nouns.

\subsubsection{With tal}

Another determiner that enters into a relationship with the articles is tal. This is a very interesting case, since, although combination with the article is never a majority variant, the presence of the article creates a functional opposition, which again may be the result of capitalization. El/la tal $+\mathrm{N}$, which was fairly frequent until the 17th century, is always anaphoric (22a) and is a near synonym of the demonstrative este/esta; el/la tal, with no noun, is also used pronominally (22b). Up until the 18th century, un/una tal $\mathrm{N}$ had the corresponding consecutive sense of a degree (22c) or comparison ("of this kind") (22d), but it then acquires a secondary meaning of "a certain N", especially with proper nouns, which from this century comes to be predominant and is its present-day sense (22e). In this way, tal with an indefinite article shows a certain independence of tal with the definite article, and it cannot be said that after this century their evolution is parallel. In Table 14, the statistics obtained from $\mathrm{CdE}$ for the raw el/la tal $+\mathrm{N}$, un/una tal $+\mathrm{N}$ are given, together with an estimated figure for $\varnothing+t a l+\mathrm{N}$, calculated on the basis of the total number of occurrences of tal $\mathrm{N}$ minus those of tal $\mathrm{N}$ preceded by an article: the figures for $e l / l a+t a l+N, u n / u n a+t a l+N$ therefore cannot be exact, but, even so, the figures are highly suggestive.

Table 14. tal in CdE (raw occurrences).

\begin{tabular}{|r|r|r|r|}
\hline & el/la tal $\mathrm{N}+$ & un/una tal $\mathrm{N}$ & $\varnothing$ tal $\mathrm{N}+$ \\
\hline $1200 \mathrm{~s}$ & 33 & 3 & 4358 \\
\hline $1300 \mathrm{~s}$ & 54 & 3 & 1784 \\
\hline $1400 \mathrm{~s}$ & 1159 & 2 & 5146 \\
\hline $1500 \mathrm{~s}$ & 568 & 219 & 10,090 \\
\hline $1600 \mathrm{~s}$ & 201 & 21 & 6025 \\
\hline $1700 \mathrm{~s}$ & 264 & 55 & 4540 \\
\hline $1800 \mathrm{~s}$ & 352 & 43 & 9719 \\
\hline $1900 \mathrm{~s}$ & 26 & 22 & 4514 \\
\hline
\end{tabular}

t based on a sample of 1000 sentences. 
(22) a. donde había sido corregidor sin haber aún sacado a su mujer del distrito de su corregimiento por haber poco tiempo que había dejado el tal oficio (CdE: Pedro Mariño de Lobera, Crónica del Reino de Chile, 16th cent.)

"where he had been corregidor, without yet having brought his wife from the district of his jurisdiction because of the short space of time which had passed since he had left this office"

b. $\quad y$ si el tal, como atrás dixe, había subido a ser señor por sus hazañosos hechos, por extenso contaban sus valentías y cómo de grado en grado había subido y tenido tanta fortuna, que meresciese en su muerte ser tan honrado (CdE: Francisco Cervantes de Salazar (1514-1575), Crónica de la Nueva España (1544)).

"And if such a person, as I said earlier, had risen to the nobility through his glorious deeds, they recounted his brave acts and how he had risen rank by rank and acquired such a great fortune that he deserved to be so honoured on his death."

c. Y en llegando le da un tal golpe de través encima el yelmo que muy lexos de allí le hizo saltar muchas centellas (CdE: Diego Ortúñez de Calahorra, Espejo de príncipes y cavalleros. Libro III, S.XVI).

"And when he reached [him] he gave him such a sideways blow on his helmet that he made sparks fly a great distance"

d. No pudo Numisio resistir a una tal confabulación de voluntades, y convino en trasladarse a Roma con su mujer y su cuñado (CdE: Joaquín Costa (1846-1911), Último día del paganismo y primero de lo mismo, 1878).

"Numisio could not resist such a conspiracy of wills, and he agreed to move to Rome with his wife and brother-in-law."

e. Refiere que el primero que procuró averiguarla por este método fue un tal Felipe Guillén, boticario de Sevilla (CdE: Martín Fernández de Navarrete (1756-1844), Disertación sobre la historia de la nautica y de las ciencias matemáticas que han contribuido a sus progresos entre los españoles, 1800). "It reports that the first person who tried to verify it by this method was a certain Felipe Guillén, a pharmacist in Seville."

\section{Conclusions}

The extension of the functions of the Castilian articles traced in outline here exemplify capitalization or serial adfunctionalization. This is particularly clear in the case of the indefinite article, which still includes its original value as a numeral. The definite article, it is true, loses some of the deictic force of the demonstrative from which it derives (and accordingly contrasts functionally with the new Romance demonstratives), but it continues another of the fundamental functions of the demonstrative, that of anaphoric reference. In the course of their history to date, both articles have developed a range of additional, though related, functions. The process is therefore comparable to that undergone by estar and the reflexive (non-exaptive) and to the neo-neuter lo (exaptive).

As regards the other properties that I have identified as typical of capitalization, I have demonstrated that the articles make overt some distinctions that were previously covert, chiefly and most importantly the distinction between anaphoricity or "definiteness" and non-anaphoricity or "indefiniteness". At the same time, it is also clear that, in many, if not the majority, of their functions, the articles are a superfluous element whose value depends on the discourse context or pragmatic conditions. The possible ambiguity of the definite article between anaphoricity and genericness in fact does not present difficulties of interpretation.

It is also clear that the expansion of the articles brought about the creation of new expressive possibilities, mainly the opposition between the indefinite article and the zero article.

The effect that the articles have had on the grammatical system is more difficult to evaluate. The articles play their part in the emergence in Romance of a DP (Determiner Phrase) structure (Ledgeway 2011, p. 409); it does not seem that the articles created the system of determiners, however, but rather that they broadened it and opened the way for the incorporation (and maybe also coining) of other elements, such as the more explicit anaphoric expressions of modern Castilian. It is also possible that the dependence of the development of the indefinite article on that of the definite article can be overestimated, since from the 16th century the indefinite article has shown a marked originality by 
comparison with the definite. It is perhaps in the interaction of the articles with other determiners that we see the clearest impact of a structural kind.

The history of the articles is therefore a topic of great interest for a theory of adfunctionalization, despite the many challenges it also poses.

Funding: This research received no external funding

Conflicts of Interest: The author declares no conflict of interest.

\section{References}

Abel, Fritz. 1971. L'adjectif démonstratif dans la langue de la Bible latine. Etude sur la formation des systèmes déictiques et de l'article défini des langues romanes. (= Beihefte zur Zeitschrift für romanische Philologie, 125.). Tübingen: Niemeyer.

Alonso, Amado. 1933. Estilística y gramática del artículo en español. Volkstum und Kultur der Romanen 6: 189-209.

Alvarez Martínez, María Ángeles. 1986. El artículo como entidad funcional en el español de hoy. Madrid: Gredos.

Álvarez Menéndez, Alfredo. 1970. Énfasis y transposición de oración a sustantivo. Revista Española de Lingüística 17: $347-70$.

André, Aurélie, and Michèle Fruyt. 2012. Le rôle de is dans le changements de l'endophore et de la déixis en latin. In Latin Vulgaire - Latin Tardif IX. Actes du IXè colloque international sur le latin vulgaire et tardif, Lyon, 2-6 Septembre 2009. Lyon: Maison de l'Orient et de la Méditéranée-Jean Pouilloux.

Badía Margarit, Antonio. 1951. Gramática histórica catalana. Barcelona: Noguer.

Bauer, Brigitte L. M. 2009. Strategies of definiteness in Latin: implications for early Indo-European. In Grammatical Change in Indo-European Languages. Papers Presented at the workshop on Indo-European Linguistics at the XVIIIth International Conference on Historical Linguistics, Montreal. Amsterdam and Philadelphia: John Benjamins.

Butt, John, and Carmen Benjamin. 2013. A New Reference Grammar of Modern Spanish, 5th ed. London: Arnold.

Carlier, Anne. 2001. La genèse de l'article un. Langue française 130: 65-88. [CrossRef]

Chesterman, Andrew. 1991. On Definiteness. Cambridge: Cambridge University Press.

Company Concepción. 1991. La extensión del artículo en el español medieval. Romance Philology 44: 402-24.

Davies, Mark. 2002-2019. Corpus del Español: 100 Million Words, 1200s-1900s. Available online: http:/ / www. corpusdelespanol.org/hist-gen/ (accessed on 31 October 2017).

De Bruyne, Jacques. 1995. A Comprehensive Spanish Grammar, adapted with additional material by Christopher J. Pountain. Oxford: Blackwell.

Faingold, Eduardo D. 2003. The Development of Grammar in Spanish and the Romance Languages. Basingstoke: Palgrave Macmillan.

Garachana Camarero, Mar. 2009. La creación y generalización del artículo indefinido. In Sintaxis histórica de la lengua española. Segunda parte: La frase nominal. Edited by Company Concepción. México: Universidad Autónoma de México/Fondo de Cultura Económica, pp. 389-464.

Gardiner, Alan H. 1932. The Theory of Speech and Language. Oxford: Clarendon.

Greenberg, Joseph H. 1978. How does a language acquire gender markers? In Universals of Human Language. Stanford: Stanford University Press.

Gutiérrez Rexach, Javier. 1999. The structure and interpretation of Spanish degree-neuter constructions. Lingua 109: 35-63. [CrossRef]

Harris, Martin B. 1978. The Evolution of French Syntax: A Comparative Approach. London: Longman.

Harris, Martin B. 1980. The marking of definiteness: A diachronic perspective. In Papers from the Fourth International Conference on Historical Linguistics. Amsterdam and Philadelphia: John Benjamins.

Kabatek, Johannes. 2012. Nuevos rumbos en la sintaxis histórica. In Actas del IX Congreso Internacional de Historia de la Lengua Española. Santiago de Compostela: Meubook.

Lass, Roger. 1990. How to do things with junk: Exaptation in language evolution. Journal of Linguistics 26: 9-102. [CrossRef]

Ledgeway, Adam. 2011. Syntactic and Morphosyntactic Typology and Change. In The Cambridge History of the Romance Languages. Volume 1. Structures.. Edited by Martin Maiden, John Charles Smith and Adam Ledgeway. Cambridge: Cambridge University Press, pp. 382-471.

Lyons, John. 1968. Introduction to Theoretical Linguistics. Cambridge: Cambridge University Press. 
Meillet, Par A., and Joseph Vendryes. 1966. Traité de Grammaire Comparée des Langues Classiques, 4th ed. Paris: Champion.

Moreira Rodríguez, Antonia, and John Butt. 1996. "Se de matización" and the Semantics of Spanish Pronominal Verbs. London: Department of Spanish and Spanish-American Studies, King's College London.

Ortiz Ciscomani, Rosa María. 2009. La creación y generalización del artículo definido. In Sintaxis histórica de la lengua española. Segunda parte: La frase nominal. Edited by Company Concepción. México: Universidad Autónoma de México/Fondo de Cultura Económica, pp. 273-386.

Pinkster, Harm. 1990. Latin Syntax and Semantics. London and New York: Routledge.

Pountain, Christopher J. 2000a. “Capitalization". In Historical Linguistics 1995, Volume 1: General Issues and non-Germanic Languages. Edited by John Charles Smith and Delia Bentley. Amsterdam \& Philadelphia: John Benjamins, pp. 295-309.

Pountain, Christopher J. 2000b. Pragmatic Factors in the Evolution of the Romance Reflexive (with special reference to Spanish). Hispanic Research Journal 1: 5-25. [CrossRef]

Pountain, Christopher J. 2000c. "La supuesta ambigüedad del reflexivo español”. In Actes du 22e Congrès de Linguistique et de Philologie Romanes, vol. VII, ed. Edited by Annick Englebert, Michel Pierrard, Laurence Rosier and Dan Van Raemdonck. Tübingen: Niemeyer, pp. 615-24.

Pountain, Christopher J. 2008. The Genius of Language. Public Lecture given at the University of Newcastle-upon-Tyne. Available online: http://webspace.qmul.ac.uk/cjpountain/genius.pdf (accessed on 31 October 2017).

Pountain, Christopher J. 2015. "Lo + adjetivo: por la exaptación a la capitalización". In Actas del IX Congreso Internacional de Historia de la Lengua Española (Cádiz, 2012). Edited by José Marí García Martín, Teresa Bastardín Candón and Manuel Rivas Zancarrón. Madrid and Frankfurt: Iberoamericana/Vervuert, vol. I, pp. 1035-48. Sapir, Edward. 1921. Language: An Introduction to the Study of Speech. London: Hart-Davis.

Smith, John Charles. 2011. Change and Continuity in Form-Function Relationships. In The Cambridge History of the Romance Languages. Volume 1. Structures.. Edited by Martin Maiden, John Charles Smith and Adam Ledgeway. Cambridge: Cambridge University Press, pp. 268-317.

Vincent, Nigel. 2017. Determination and quantification. In Manual of Romance Morphosyntax and Syntax. Edited by Andreas Dufter and Elisabeth Stark. Berlin and Boston: Mouton de Gruyter, pp. 727-70.

Voltaire, Oeuvres Completes. 1879. Dictionnaire Philosophique. CEuvres Complètes. Paris: Garnier, vol. 19. First published 1757.

(C) 2019 by the author. Licensee MDPI, Basel, Switzerland. This article is an open access article distributed under the terms and conditions of the Creative Commons Attribution (CC BY) license (http:/ / creativecommons.org/licenses/by/4.0/). 
Article

\title{
Indefinite Article + Possessive + Noun in Spanish: A Case of Refunctionalization?
}

\author{
Enrique Pato \\ Département de littératures et de langues du monde, Université de Montréal, Montréal, QC H3C 3J7, Canada; \\ enrique.pato-maldonado@umontreal.ca
}

Received: 9 October 2018; Accepted: 14 November 2018; Published: 19 November 2018

\begin{abstract}
The phenomenon under discussion is an example of a grammatical change that can be explained by refunctionalization, and as such, can be understood as the acquisition of a new meaning by an 'endangered' grammatical construction, which is reassigned to express another value. Refunctionalization involves the development of a new function (in this case a syntactic-semantic one). When an item loses its function, or is marginal within a system, it can be lost (as happens with the construction under study in Standard Spanish), it can be 'saved' as a marginal element (as in some areas of American Spanish varieties) or it can be reused for other purposes (as in the Central American Spanish varieties). The latter case presents new discursive values. Hence, this construction should be understood as an example of reusing grammatical functionally opaque material for new purposes.
\end{abstract}

Keywords: Spanish; syntax variation; <indefinite article + possessive + noun> construction; refunctionalization

\section{Introduction}

Naming and classifying grammatical phenomena is useful for acquiring a better understanding of them. Theory may help us understand better the phenomenon we are studying, but what claims for a more or less far-ranging theory is the occurrence of the construction itself. The Spanish linguistic construction <indefinite article + possessive + noun> (e.g., un.MSG su.M/FSG/PL amigo.MSG 'a his/her/their friend'), has been awakening a fair amount of interest, at least in the last two decades.

Refunctionalization (or exaptation) is a specific kind of adaptation (Heine 2003; Norde 2009). Briefly, exaptation happens when a grammatical form $G_{1}$ derives from a form without grammatical meaning $G_{0}$ (less grammatical). Adaptation happens when a grammatical form $G_{1}$ derives from a more grammatical form $\mathrm{G}_{2}$. We define the notion of refunctionalization (or exaptation) as the process in which a grammatical element, which is close to disappearing, acquires a new 'meaning', and is eventually relocated within the grammatical system in order to express another value or another function. Adfunctionalization (or capitalization), on the other hand, is the addition of a new value to the already existent meaning/function of an element. Both processes help us understand better how grammatical material is formed and maintained within languages and they also help us 'name' the construction under discussion ('un su amigo'). ${ }^{1}$

Refunctionalization can take place when a grammatical form loses almost all its original semantic content and is newly employed as a semantically distinct form ('reanalysis of function' à la Heine 2003). It happens also when the item in question does not have a function (i.e., 'linguistic junk'), although it

1 Other terms that have been employed are exaptation (Lass 1990, 1997; Norde 2002; Vincent 1995), capitalization (Pountain 2000), regrammaticalization of desemanticized forms (Greenberg 1991), functional renovation of old forms (Brinton and Stein 1995), degrammaticalization (Heine 2003; Norde 2002, 2009), hipoanalysis (Croft 2000), etc. These different terms illustrate the terminological confusion that exists, since they do not refer to different types of change (Narrog 2007). 
might not necessarily be totally 'junk' (Lass 1990). The target of exaptation may be an already existent category (Traugott 2004). In contrast to the typical processes of grammaticalization, refunctionalization can be a discontinuous change (or 'a jump', Giacalone Ramat and Hopper 1998; Smith 2011). The cases in which the meaning of a construction is displaced to a specific context are also considered instances of exaptation (like 'un su amigo').

Interestingly, the apparition of a certain phenomenon can be both the result of refunctionalization and of adfunctionalization: for instance, it might be due to refunctionalization for one specific variety $X$ (e.g., Central American Spanish), and due to adfunctionalization for another variety Y (e.g., Historical and Standard Spanish). The 'obsolete' material may be lost or might be used again in order to express an existent grammatical category, or in order to encode a brand new category.

The whole process is related to the development of morphological material that is difficult to acquire-it is this inadequate acquisition that enables the possibility of reanalysis for that trait (Willis 2016).

The main purpose of this paper is to demonstrate that <indefinite article + possessive + noun> construction in Central American Spanish can be explained as a case of refunctionalization.

\section{Application of the Term and Interest in the Construction}

The main question is whether the history of the 'un su amigo' construction-as a process of grammatical change-can be explained by refunctionalization (or exaptation). As previously stated, exaptation implies the development of a new function which, in this case, would be both syntactic and semantic. When an element loses its function or it becomes marginal within a system, it may either disappear (which is what has happened with the 'un su amigo' construction in Standard Spanish), survive as a marginal element (as in some areas of American Spanish varieties like Northern Argentina) or it might be used anew for other communicative purposes (as in South Mexico and Central America varieties). This construction is an example of reutilization of functionally opaque grammatical material for new purposes. The aforementioned construction would have been assimilated into the vocabulary as a starting point to exaptation.

The stages involved in this paper deal with the history of the Spanish language (both Historical and Standard Spanish and Central America varieties) and the different values of the construction.

It is crucial to note that the exaptated construction shows 'conceptual novelty' - the speaker analyzes a semantic property found in the context as an inherent property of the lexical unit (Croft 2000). Exaptation is distinct from grammaticalization inasmuch as, in the latter, a lexical element acquires a grammatical function and suffers formal changes within this process, while, in the former, an old and fading grammatical form is retained and assigned a new function (Vincent 1995).

Exaptation and grammaticalization are both based on reanalysis and lead to the formation of grammatical elements-the difference lies in the direction of the process. The reasons for these processes have to be looked for in the communicative needs of the speakers and most of the time can be traced to a tendency to gain clarity of expression. These phenomena produce both an enrichment of the available discursive tools and a progressive grammaticalization of new values within new contexts (Company Company, Concepción 2005), as will be seen see in Section 4. Referential values are weakened, while textual and discursive values end up strengthened.

At least two general questions have determined the interest in the study of this construction:

(1) Is it a case of syntactic borrowing? The answer is no, since it is not documented exclusively in areas with either a strong indigenous language influence or a high index of bilingual speakers. García Tesoro (2011, p. 206), in the only work that has been concerned with Maya speakers, demonstrates that the structure under study "shows itself with a similar frequency of utilization both in monolingual and bilingual speakers" (author's translation).

(2) Is the value in medieval and modern Spanish the same? The answer is also no-a new communicative purpose is attested in modern Spanish (Central America varieties). As we know, possession is culturally determined; it is a 'biocultural' domain (Carlson and Payne 1989; Seiler 1983). Nowadays, it is the appreciation that the speaker makes of a specific situation that determines the use of the 
construction, which places the possessee on focus and marks it as a relevant syntactic constituent: a pragmatically and perceptively relevant entity. That is, the construction moves from a textual meaning to a discursive meaning (Company Company, Concepción 2005; Palacios Alcaine 2004) as we will see.

\section{Some Remarks about the Construction}

As we know, the 'un su amigo' construction is an overspecified structure that conveys the value of inherent possession, that is, in which 'the owned cannot be thought of without the owner'. Recalling previous studies, Pato (1999, 2002), García Tesoro (2002, 2011), Palacios Alcaine (2004), Nieuwenhuijsen (2005, 2007), and Company Company, Concepción $(2005,2009)$, the construction:

- Is documented in all Mesoamerica, from Southern Mexico to Panama.

- Is not a stigmatized construction in those varieties.

- Is not a trait exclusive to popular level.

- Is neither exclusive nor specific of indigenous (autochthon) speakers.

- Is part of the standard register within Central American Spanish.

- May be explained without having to appeal to 'contact' or 'convergence' between Spanish and Maya languages (Company Company, Concepción 1995, 2005; Martin 1985; Pato 2002).

- There are not studies that have delimited its sociolinguistic profile (and the differences within the different communities) yet cf. (Pato 2002).

- Is attested throughout the whole history of the Spanish language.

On the other hand, its frequency within the corpuses we have consulted or compiled is extremely variable. For example, there are 1149 cases (from 13th to 16th centuries) in CORDE (Corpus diacrónico del español) and 52 cases (30 of them in Guatemala and 11 in Mexico) in CREA (Corpus de referencia del español). García Tesoro (2002) works with 81 cases from interviews (Guatemala); Palacios Alcaine (2004) works with 60 literary cases from Guatemala, El Salvador, and Honduras; Nieuwenhuijsen (2005) uses 629 cases from Corpus del español (339 of them from the 16th century); Silva Ceceña (2005) studies 252 cases; Company Company, Concepción $(2005,2009)$ analyzes 97 cases (in a primary corpus) and 96 from narrations and interviews of Central American indigenized Spanish (Chiapas and Guatemala); Nieuwenhuijsen (2007) found 173 examples within the press of Guatemala («La Hora») and Mexico («La Jornada»); and Elsig (2015) used 120 examples from the PRESEEA Guatemala Corpus. The data regarding frequency is relevant to support general conclusions about the construction.

The construction has been very well defined in previous works. The following is just a brief résumé. We know that its extension went from masculine to feminine ('un su $>$ una su'), from singular to plural ('un su > unos sus'), and apparently from 3rd person to 1st and 2nd person. Nieuwenhuijsen (2007) indicates that the instances in the 3rd person are the most numerous, Company Company, Concepción (2009) finds the same tendency (up to $86 \%$ ), and Pato (2002) concurs. The construction also changed from introducing an entity and delimitating it (with reference to other similar entities) to introducing topical and important entities that are going to subsist within the discourse. It also extended from [+human] nouns to [-human] nouns, that is, it has suffered a semantic demarcation (Company Company, Concepción 2005, 2009; Nieuwenhuijsen 2005; Palacios Alcaine 2004; Pato 2002).

Moreover, its use can be 'measured' in informational and argumentative terms. First of all, the use of this construction motivated by the context, i.e., the <indefinite article + possessive + noun> construction acts as an emphasizer of narrative discourse, as will be seen in the following section. The construction also acquires a textual meaning (discursive value), dependent on the discourse and independent from the external situation. 


\section{Different Values of Indefinite Article + Possessive + Noun Construction}

\subsection{Partitive Value}

The main meaning of this construction is 'one of/among several', which is attested since Medieval Spanish (Company Company, Concepción 2005; Keniston 1937; Palacios Alcaine 2004; Pato 1999, 2002; Serradilla Castaño 2007). It appears with [+human] nouns in Medieval Spanish (cf. 1a), and also in Central America varieties (cf. 1b Costa Rica, 1c Guatemala, 1d Belize):

(1) a. El lombardo adoleçió de dolençia mortal, et un su amigo que había, desque lo vio en la muerte, consejol que se confesase en Sancto Domingo [D. Juan Manuel, El Conde Lucanor, Ex. XIV, c. 1335, in (Pato 2002)].

"The Lombard man suffered from a fatal illness, and his friend that he had, when he saw him in death, advised him to confess his sins in Santo Domingo"

b. A las diez preguntas dijo este testigo que sabe lo contenido en ella porque un su hermano se lo dijo [«Información de méritos y servicios de Miguel Sánchez de Guido», CORDE, Costa Rica, 1566].

"To those ten questions this witness said that he knows what is contained in it because his brother told him"

c. E: ¿Ha corrido alguna maratón? I: Yo tengo un mi hijo que tiene como vicio correr y participa en todas las maratones, y yo era su único fanático [«D frente», Francisco M. Martínez, Prensa Libre (Guatemala) 04-10-2004].

"E: Have you ever run a marathon? I: I have my son whose vice is to run and participates in all marathons, and I was his only fan"

d. Soñaba el entierro de mi abuelito, y que cuando abrían el cajón no era mi abuelito el que estaba, era un mi tío, en realidad fue el que se murió después ... [Belizean Spanish, English and Creole Corpus, M-35, West, in (Fuller Medina 2016)].

"I dreamed my grandfather's funeral, and when they opened the drawer it was not my grandfather who was in it, it was my uncle, actually he was the one who later died ... "

\subsection{Iterative Value}

The construction also holds an iterative or habitual value. In this case the information is known and shared by the speaker and the hearer (García Tesoro 2002; Palacios Alcaine 2004; Pato 2002). The possessive relationship is established by the possessive, not by the context. It appears with [-animate] nouns in Central America varieties (cf. 2a-b Guatemala):

(2) a. Clemente siempre andaba con los huesos de su hijo en una su bolsa [H-20, ladino, monolingüe, in (Pato 1999, 2002)].

"Clemente was always with the bones of his son in his bag"

b. «El caso de un fantasma (espanto) que regala dinero». Pues eh ... dicen que antes, por allí por la ... por allí por los Ucaliptos, era la ... el lugar donde tenía [el espanto] un su sitiecito [C. A. Lara Figueroa, Cuentos y consejas populares de Guatemala, 1990, p. 70, in (Palacios Alcaine 2004)].

"The case of a ghost (fear) that gives money away'. Well, uh ... they say that earlier, over there by the ... over there by the Eucalyptus, that was the ... the place where it [the ghost] had its place" 


\subsection{Emphatic Value}

The emphatic, enhancement or intensifier values of the construction are used in order to indicate related or important concepts (Company Company, Concepción 2005, 2009; García Tesoro 2002; Nieuwenhuijsen 2005, 2007; Palacios Alcaine 2004; Pato 2002). It is also used for marking decreasing size ('smallness or insignificance') and affectivity (Martin 1985; Pato 2002). The presence of the diminutive favors the construction (Nieuwenhuijsen 2007). It is habitually attested with [-animate] and [+countable] nouns. It conveys pragmatic, quantitative or qualitative information (Palacios Alcaine 2004), as we see in South Mexico and Central America varieties (cf. 3a Chiapas, 3b Guatemala):

(3) a. A don Límbano le encargamos unos nuestros cotorritos, cuando tengan cría los que compró, que nos tome en cuenta porque nos gusta mucho los pajaritos [«Las Comadres». Diario de Comitán (Chiapas, México), 06-09-2005].

"We ask Don Límbano for a few small parrots, when the birds that he bought breed, he should take us into account because we love little birds"

b. El papá ... este ... le regaló unos centavos al niño pobre y la mamá le regaló unos sus centavos al niño rico. Agarraron camino ... Pero en eso el rico le dice: -Mirá, yo cargo bastante dinero. -Yo no tengo, contestó el pobre ... [C. A. Lara Figueroa, Cuentos populares de encantos y sortilegios en Guatemala, 1992, p. 67, in (Palacios Alcaine 2004)].

"The dad ... mm ... he gave some pennies to the poor kid and the mother gave a few cents to the rich kid. They started their way ... But the rich kid says: -Look, I carry enough money. -I do not have any, answered the poor kid ..."

\subsection{Discursive-Pragmatic Value}

The discursive pragmatic value of the construction is attested in narrations, tales and also in the opinion section (such as letters/messages from hearers or readers) of mass media. It marks special relevance and acts as discursive focus (Palacios Alcaine 2004). It presents important entities that have referential persistence throughout the narration (Company Company, Concepción 2005). It is attested with any kind of noun, and it has no semantic restrictions in Central America varieties (cf. $4 a-c$ Guatemala). The nuance of 'affectivity' may be maintained. The main problem with this value lies in how to differentiate the kind of context in which it appears, a key feature for the aim of 'un su amigo' exaptation. The referential persistence mentioned is also an important contextual feature (cf. 4c, nonliterary example).

(4) a. Ella que iba a preguntar a una casita que había allí con una su ventanita, cuando vio por la ventana, estaba el príncipe. Pero él le dijo que si ella no entraba por la ventana entonces no lo volvería a ver nunca, entonces ella saltó la ventana y allí agarró al príncipe y se abrazaron y vivieron felices [C. A. Lara Figueroa, Cuentos populares de encantos y sortilegios en Guatemala, 1992, p. 37, in (Palacios Alcaine 2004)].

"She was going to ask [something] in a little house that was over there, with its window, when she saw through the window that the prince was there. But he told her that if she did not come through the window then she would not see him ever again, so she jumped through the window and grabbed the prince and they hugged and they lived happily"

b. Eran muy pobres, tenían una su vaquita que ordeñaban ... m . . d'eso vivían, de su lechita [C. A. Lara Figueroa, Cuentos populares de encantos y sortilegios en Guatemala, 1992, p. 130, in (Palacios Alcaine 2004)].

"They were very poor, they had a cow that they milked ... m ... they made a living out of that, of its milk" 
c. No será, Don Estuardo, que usted lo que busca es un su puestecito en el gobierno, por eso habla mucho, por eso anda criticando todo, por eso critica a la misma 'cobardía chapina'. Tenga cuidado, no hable mucho, porque lo van a acusar de a saber ni qué, y usted está patojo. Si en Guatemala las cosas no van a cambiar, hombre [Estuardo Zapeta, «iViva la cobardía chapina!», La Hora (Guatemala), 21-04-2003].

"It would not be, Don Estuardo, that you are looking for a small position in the government, that's why you talk so much, why you criticize everything, why you criticize the 'Chapina cowardice'. Be careful, do not talk a lot, because they will accuse you of who knows why, and you are still a kiddy. Things are not going to change in Guatemala, man"

As we saw in previous examples, the structure acquires another nuance (a connotative nuance), far beyond its literal meaning. Such a new meaning depends on the actual context and triggers various pragmatic inferences, a discourse-pragmatic value. That is why previous knowledge of the situation is required to foster its discursive processing. Among the variables determining the environment of discourse the following have been singled out: text organization, source of information, attitudes of the speaker (subjectivity), speaker-hearer interactions (intersubjectivity), situation of discourse, and world knowledge (cf. for example Kaltenböck et al. 2011). A discussion which I reserve for future research cf. (Pato 2015).

\section{Final Considerations and Conclusions}

The construction under analysis can be explained thanks to grammaticalization theory. Opaque (and obsolete) grammatical material, which cannot be spontaneously understood, might be reused for new purposes in new varieties as phenomena of the narrative discourse (Van Dijk and Kintsch 1983). The possessive construction considered here is associated to structures of focus and topic-the construction marks also a discursive topic (Company Company, Concepción 2005; Pato 2015).

In refunctionalization processes, the speakers create a grammatical model where there was previously none. The construction gets to convey a (new) value (see examples in 4), different from the one it used to have in other stages of the evolution of the language (see examples in 1 to 3) (Harris and Campbell 1995; Willis 2010). The new values do not arise from the properties of the old ones: it is not a matter of acquisition and adaptation of the old system, rather, a new system is being created (Willis 2016).

Exaptation is not necessarily deemed to contribute to create a new function in the system-what is important is that there is a new function of the opaque (and obsolete) trait in the process of exaptation (Willis 2010, 2016).

On the other hand, polyfunctionality of contexts and constructionalization (Traugott and Trousdale 2014) also have a role in the process. The forms ('un $+\mathrm{su}^{\text {') }}$ maintain their basic meaning, although in certain cases the possessive may not be necessary; polysemy lies within the contexts (what is meant in specific contexts), so the locus of this grammatical change would be the context. That is to say, the value of the construction is inferred from the discursive context. Therefore, we are faced by a change triggered by specific contextual use.

Funding: This research received no external funding.

Conflicts of Interest: The author declares no conflicts of interest.

\section{References}

Brinton, Laura, and Dieter Stein. 1995. Functional renewal. In Historical Linguistics 1993: Selected Papers from the 11th International Conference on Historical Linguistics (= Current Issues in Linguistic Theory, 124). Edited by Henning Andersen. Amsterdam and Philadelphia: John Benjamins, pp. 33-47.

Carlson, Robert, and Doris Payne. 1989. Genitive Classifiers. In Proceedings of the Fourth Meeting of the Pacific Linguistic Conference (= Pacific Linguistics Conference, 4). Edited by Robert Carlson, Scott DeLancey, Spike Gildea, Doris Payne and Anju Saxena. Eugene: University of Oregon, pp. 87-119. 
Company Company, Concepción. 1995. Cantidad vs. cualidad en el contacto de lenguas. Una incursión metodológica en los posesivos 'redundantes' del español Americano. Nueva Revista de Filología Hispánica 43: 305-39.

Company Company, Concepción. 2005. Frecuencia de uso y contacto lingüístico en sintaxis. Artículo indefinido + posesivo en el español americano. Spanish in Context 2: 131-56.

Company Company, Concepción. 2009. Artículo + posesivo + sustantivo y estructuras afines. In Sintaxis histórica de la lengua española. Segunda Parte: La frase nominal. Edited by Company Company, Concepción. Mexico City: Fondo de Cultura Económica \& Universidad Nacional Autónoma de México, vol. I, pp. 759-880.

Croft, William. 2000. Explaining Language Change: An Evolutionary Approach. Harlow: Longman.

Elsig, Martin. 2015. La posesión atributiva en el español centroamericano: Variantes y funciones. Paper presented at the XX Congreso de la Asociación Alemana de Hispanistas 2015/20, Deutscher Hispanistentag, Heidelberg, Germany, March 18-22.

Fuller Medina, Nicté. 2016. Language Mixing in Northern and Western Belize: A Comparative Variationist Approach. Ph.D. Thesis, University of Ottawa, Ottawa, ON, Canada.

García Tesoro, Ana Isabel. 2002. El español en contacto con lenguas mayas: Guatemala. In El Indigenismo Americano III. Actas de las Terceras Jornadas sobre Indigenismo Americano. Edited by Azucena Palacios and Ana Isabel García. Valéncia: Universitat de Valéncia, pp. 31-58.

García Tesoro, Ana Isabel. 2011. Cada quien tiene un su nagual'. La construcción artículo indefinido + posesivo + nombre en el español de Guatemala. The Journal of the Faculty of Foreign Studies 43: 197-209.

Giacalone Ramat, Anna, and Paul J. Hopper. 1998. Introduction. In The Limits of Grammaticalization (= Typological Studies in Language, 37). Edited by Anna Giacalone Ramat and Paul J. Hopper. Amsterdam and Philadelphia: John Benjamins, pp. 1-11.

Greenberg, Joseph H. 1991. The last stages of grammatical elements: Contractive and expansive desemanticization. In Approaches to Grammaticalization (= Typological Studies in Language, 19.1). Edited by Elizabeth Closs Traugott and Bernd Heine. Amsterdam and Philadelphia: John Benjamins, vol. I, pp. 301-14.

Harris, Alice C., and Lyle Campbell. 1995. Historical Syntax in Cross-Linguistic Perspective. Cambridge: Cambridge University Press.

Heine, Bernd. 2003. On degrammaticalization. In Historical Linguistics 2001: Selected Papers from the 15th International Conference on Historical Linguistics (= Current Issues in Linguistic Theory, 237). Edited by Barry J. Blake and Kate Burridge. Amsterdam and Philadelphia: John Benjamins, pp. 163-79.

Kaltenböck, Gunther, Bernd Heine, and Tania Kuteva. 2011. On thetical grammar. Studies in Language 35: 852-97. [CrossRef]

Keniston, Hayward. 1937. The Syntax of Castilian Prose: The Sixteenth Century. Chicago: The University of Chicago Press.

Lass, Roger. 1990. How to do things with junk: Exaptation in language evolution. Journal of Linguistics 26: 79-102. [CrossRef]

Lass, Roger. 1997. Historical Linguistics and Language Change. Cambridge: Cambridge University Press.

Martin, Laura. 1985. Una mi tacita de café: The Indefinite Article in Guatemalan Spanish. Hispania 68: 383-87. [CrossRef]

Narrog, Heiko. 2007. Exaptation, Grammaticalization, and Reanalysis. California Linguistics Notes 32: 1-24.

Nieuwenhuijsen, Dorien. 2005. Diacronía y diatopía de las construcciones posesivas. Estudios de Lingüística del Español 22: 1-10.

Nieuwenhuijsen, Dorien. 2007. Un amigo suyo se enfrenta con un su amigo. El uso de dos construcciones posesivas en dos periódicos de Guatemala y México. Nueva Revista de Filología Hispánica 55: 321-50.

Norde, Muriel. 2002. The final stages of grammaticalization: Affixhood and beyond. In New reflections on grammaticalization (= Typological Studies in Language, 49). Edited by Ilse Wischer and Gabriele Diewald. Amsterdam and Philadelphia: John Benjamins, pp. 45-65.

Norde, Muriel. 2009. Degrammaticalization. Oxford: Oxford University Press.

Palacios Alcaine, Azucena. 2004. El valor discursivo en las construcciones de artículo indefinido + posesivo + nombre en el español de Centroamérica. Signo y Seña 13: 185-214.

Pato, Enrique. 1999. Sobre el artículo con posesivo en español medieval. Unpublished manuscript.

Pato, Enrique. 2002. La estructura posesiva una mi amiga en el español de Guatemala. In El Indigenismo Americano III. Actas de las Terceras Jornadas sobre Indigenismo Americano.. Edited by Azucena Palacios and Ana Isabel García. Valéncia: Universitat de Valéncia, pp. 121-54. 
Pato, Enrique. 2015. El posesivo (antepuesto) tónico en español: ¿fenómeno de foco y contraste? Dialectologia 14: $47-73$.

Pountain, Christopher J. 2000. Capitalization. In Historical Linguistics 1995, Volume 1: General Issues and non-Germanic Languages (= Current Issues in Linguistic Theory, 161). Edited by John Charles Smith and Delia Bentley. Amsterdam and Philadelphia: John Benjamins, vol. I, pp. 295-309.

Seiler, Hansjakob. 1983. Possession, as an Operational Dimension of Language. Tübingen: Narr Verlag.

Serradilla Castaño, Ana. 2007. Sobre la evolución del artículo + posesivo en el español peninsular: causas de su pervivencia y comparación con la situación del español americano. In Actes du XXIV Congrès International de Linguistique et Philologie Romanes. Edited by David Trotter. Tübingen: Max Niemeyer, vol. II, pp. 319-30.

Silva Ceceña, Rosaura. 2005. La construcción artículo indefinido + posesivo + sustantivo en el español antiguo. Estructura y diacronía. Bachelor's thesis, Universidad Nacional Autónoma de México, Ciudad de México, México. Smith, John C. 2011. Change and continuity in form-function relationships. In The Cambridge History of the Romance Languages, Volume 1, Structures. Edited by Martin Maiden, John Charles Smith and Adam Ledgeway. Cambridge: Cambrigde University Press, pp. 268-317.

Traugott, Elizabeth Closs. 2004. Exaptation and Grammaticalization. In Linguistic Studies Based on Corpora. Edited by Minoji Akimoto. Tokyo: Hituzi Syobo Publishing, pp. 133-56.

Traugott, Elizabeth Closs, and Graeme Trousdale. 2014. Constructionalization and Constructional Changes. Oxford: Oxford University Press.

Van Dijk, Teun A., and Walter Kintsch. 1983. Strategies of Discourse Comprehension. New York: Academic Press.

Vincent, Nigel. 1995. Exaptation and grammaticalization. In Historical Linguistics 1993: Selected Papers from the 11th International Conference on Historical Linguistics (= Current Issues in Linguistic Theory, 124). Edited by Henning Andersen. Amsterdam and Philadelphia: John Benjamins, pp. 433-45.

Willis, David. 2010. Degrammaticalization and obsolescent morphology: Evidence from Slavonic. In Grammaticalization: Current views and issues (= Studies in Language Companion Series, 119). Edited by Ekaterini Stathi, Elke Gehweiler and Ekkehard König. Amsterdam and Philadelphia: John Benjamins, pp. 151-78.

Willis, David. 2016. Exaptation and degrammaticalization within an acquisition-based model of abductive reanalysis. In Exaptation in Language Change (= Current Issues in Linguistic Theory, 336). Edited by Muriel Norde and Freek Van de Velde. Amsterdam and Philadelphia: John Benjamins, pp. 197-225.

(C) 2018 by the author. Licensee MDPI, Basel, Switzerland. This article is an open access article distributed under the terms and conditions of the Creative Commons Attribution (CC BY) license (http:/ / creativecommons.org/licenses/by/4.0/). 
Article

\title{
Refunctionalization and Usage Frequency: An Exploratory Questionnaire Study
}

\author{
Malte Rosemeye \\ Romanisches Seminar, Albert-Ludwigs-Universität Freiburg, 79085 Freiburg, Germany; \\ malte.rosemeyer@gmail.com
}

Received: 9 October 2018; Accepted: 19 October 2018; Published: 23 October 2018

\begin{abstract}
This paper explores the relationship between refunctionalization and usage frequency. In particular, it argues that (a) refunctionalization is more likely for low-frequency construction than high-frequency constructions, and that (b) high-frequency patterns are more likely candidates as models for refunctionalization processes than low-frequency patterns. It proposes that folk etymology processes be characterized as a type of refunctionalization process because in folk etymology, obsolescent and semantically void morphemes are replaced with morphemes that actually serve a function in language. This assumption allows for an empirical investigation of refunctionalization using an exploratory questionnaire study. The results indicate that usage frequency indeed plays a role in folk etymology processes, and consequently, refunctionalization. In particular, participants were more likely to accept false etymologies when the proposed etymon had a high usage frequency than when it had a low usage frequency. In summary, the present study proposes a way to study refunctionalization processes in synchrony.
\end{abstract}

Keywords: language change; historical linguistics; refunctionalization; frequency effects; folk etymology; Spanish

\section{Introduction}

Given that "refunctionalization", the process by which a linguistic construction obtains a discourse-pragmatic function other than its original function, is a concept from historical linguistics, studies of refunctionalization normally adopt a diachronic perspective. Such diachronic studies usually identify the original discourse-pragmatic function of the construction, compare this original function to the function of the construction in later stages of the language in question, and hypothesize as to the reasons for this specific refunctionalization process.

In this paper, I explore the possibility of studying refunctionalization and the speakers' motivation for such refunctionalization processes in synchrony. In particular, I investigate two hypotheses regarding refunctionalization derived from the standpoint of usage-based linguistics. First, it can be assumed that refunctionalization processes are more likely for low-frequency constructions than high-frequency constructions because in order for refunctionalization processes to become necessary, the construction in question has to become (near-)obsolescent. Second, when searching for models for the new function of the construction, speakers might rely to a greater degree on high-frequency patterns than on low-frequency patterns. I propose that folk etymology processes can be characterized as a type of refunctionalization process because in folk etymology, obsolescent and semantically void morphemes are replaced with morphemes that actually serve a function in language. This assumption allows for an empirical investigation of the motivation of refunctionalization processes using an exploratory questionnaire study. The questionnaire asked participants whether they would accept the assumption that a target word was derived from a proposed, false etymon. It therefore allowed analyzing the participants' decision to accept or reject the folk etymology dependent of the usage 
frequency of the target word and the proposed etymon, as well as other factors. The results from the questionnaire survey indicate that as in other refunctionalization processes, there is indeed a relationship between usage frequency and folk etymology, although not all of the assumptions are validated.

This paper is structured as follows. In Section 2, I discuss the relationship of usage frequency and refunctionalization processes, establishing the two hypotheses mentioned above. In Section 3 , in turn, the relationship between refunctionalization and folk etymology is discussed. I propose that folk etymology be viewed as an instance of a process of refunctionalization. Section 4 describes the questionnaire survey conducted in order to study usage-based determinants of folk etymology. The results from the questionnaire survey are discussed in Section 5. The paper closes with a critical assessment of the findings and the methodology in the concluding Section 6.

\section{Usage Frequency as a Determinant of Refunctionalization}

In this paper, I will take the term "refunctionalization" to refer to the historical process by which a linguistic construction-a word, collocation, or grammatical pattern—obtains a discourse-pragmatic function other than its original function. As an example, consider the historical trajectory of the Swedish plural suffix - on (Norde 2009, pp. 181-83). As summarized in Norde and Van de Velde (2016, pp. 9-10), -on originally served as the nominative and accusative plural of neuter an-stems. Probably due to the fact that fruits such as hiüpon "rosehips" and smultron "wild" were usually referred to in the plural, the -on-suffix obtained a new function over time. In Modern Swedish, -on serves as a derivational suffix that is used to form fruit names such as hallon "raspberry" or lingon "lingonberry". Note that such processes have been referred to using a multitude of terms (cf. Norde and Van de Velde 2016, pp. 10-11 for a summary). For instance, I could have easily used the related notion of "exaptation" (Lass 1990) in this paper in order to refer to this kind of historical mechanism.

The example of the Swedish -on suffix serves to illustrate the relevance of usage frequency for historical refunctionalization processes. First, there is an intrinsic connection between the usage frequency of the refunctionalized construction and the refunctionalization process. Norde and Van de Velde $(2016$, p. 10) note that Old Swedish -on is a relatively infrequent plural suffix, since most plurals were formed using a zero morpheme. In other words, refunctionalization appears to occur with obsolescent constructions, i.e., constructions that are being replaced by another construction in language change, a fact that has been frequently argued for in the literature (Lass 1990, pp. 81-82; Narrog 2016, pp. 98-99; Willis 2010, p. 151). In Rosemeyer (2014, p. 95), I argued that this effect is due to the nature of conserving effects in language change. It is well known that in processes of obsolescence in language change, instantiations of the replaced construction that are of relatively high usage frequency typically resist the change longer (Bybee 2006, 2010 et passim). As a result, obsolescing constructions are usually restricted to a very limited inventory of types. The low productivity of obsolescing constructions is necessarily correlated to the loss of their original grammatical function. For instance, consider the loss of subjunctive mood in Canadian French (Poplack 2001; Poplack et al. 2013). In comparison to European French, the subjunctive is used considerably less frequently in Canadian French. Especially in oral speech, the subjunctive is often replaced with the indicative (Poplack 2001, pp. 406-7). Poplack's analysis of the determinants of the use of subjunctive mood in Canadian French reveals the existence of frequency asymmetries due to conserving effects. Thus, although the token frequency of the standard subjunctive variant is elevated, virtually all its uses are concentrated among a handful of highly favored matrix verbs collocated with a small cohort of frequent and irregular embedded verbs. Outside of these few contexts, in which its use has become ritualized, selection of the subjunctive is very rare. (Poplack 2001, p. 414)

This state of affairs involves the subjunctive no longer being used in all of the contexts in which its use would have been necessary given its original discourse-pragmatic function (the irrealis, i.e., the expression of "imagined, projected, predicted or otherwise unreal situations or events", cf. Poplack 2001, p. 406). Given that there are cases in which the irrealis is expressed using the indicative 
mood, in a sense the Canadian French subjunctive no longer fulfills the function of expressing the irrealis. Indeed, in a newer study, Poplack et al. (2013, p. 188) find that "any apparent semantic effect [i.e., irrealis, MR] was an epiphenomenon of the overriding effect of the lexical identity of the matrix". It is this fracturing of the original discourse-pragmatic function that allows for refunctionalization; given the indecisiveness of speakers as to the semantics of obsolescing constructions, they might opt to assign these constructions a new function in discourse.

The relationship between usage frequency and refunctionalization processes described in the last paragraphs can be reformulated as Hypothesis 1 below.

Hypothesis 1. Refunctionalization is more probable for low-frequency constructions than for high-frequency constructions.

The usage frequency of the refunctionalized construction is not the only way in which frequency might affect the refunctionalization process. Rather, it seems plausible to assume that when speakers refunctionalize an obsolescing construction, they take grammatical patterns or functions of high usage frequency as models. As an example, consider auxiliary selection (he comido "I have eaten" vs. soy venido "I am come") in Old and Early Modern Spanish, as analyzed in Rosemeyer (2014). Following a number of previous studies such as Mackenzie (2006) and Rodríguez Molina (2006), I conducted a quantitative analysis of the alternation in Old Spanish. This analysis suggests that even though haber "to have" and ser "to be" occur in comparable syntactic contexts (i.e., in frequent collocation with the past participle), they often have a different function. Whereas haber + PtcP has the temporal function of an anterior, ser + PtcP usually has a resultative function; it expresses the resultant state of a finished event. However, after the beginning of the 15 th century ser $+\mathrm{PtcP}$ was gradually replaced by haber + $\mathrm{PtcP}$, leading to its eventual demise in the 18th century. This obsolescence process leads to interesting changes in the use of ser $+\mathrm{PtcP}$ that suggest the existence of a refunctionalization process. In particular, the functional opposition of haber $+\mathrm{PtcP}$ and ser $+\mathrm{PtcP}$ in terms of the distinction between anterior and resultative constructions was gradually dissolved, with ser $+\mathrm{PtcP}$ being increasingly used as an anterior construction. Crucially, this refunctionalization process is not random; rather, ser $+\mathrm{PtcP}$ copied the discourse-pragmatic function of anteriority from the haber + PtcP construction that was very frequent in comparable usage contexts. In other words, the refunctionalization of ser $+\mathrm{PtcP}$ was a result from the actualization or analogical spread of haber + PtcP (see De Smet 2012 for a comprehensive discussion of actualization in language change).

As a second example, consider the changes in the paradigm of Romance oblique first- and second-person singular pronouns described in Smith (2006). In Latin, the opposition between the pronouns ME and MIHI > MI was one of case; whereas ME expressed accusative case, MIHI expressed dative case. However, due to the overall loss of the Latin case system in Proto-Romance, the two pronoun forms lost this function, and in some languages (Spanish, Northern French, and Italian dialects), came to be refunctionalized. In Modern Spanish, for instance, it is possible to use pronouns of both types in one sentence with the same reference and the same case. In (1a) me and (a) mí refer to the same referent and are datives. The difference between the two pronouns resides in the fact that whereas $m e$ is unstressed, a mí is stressed. The function of $a$ mi is "disjunctive" in the sense that it serves as a focus expression; it eliminates all other possible candidates that might have been addressed. In this sense, strong personal pronouns such as a mi are no longer marked for case, as evident from the fact that whereas the use of a weak pronoun alone is acceptable $(1 \mathrm{~b})$, the use of a strong pronoun alone is considered to be ungrammatical in most cases (Real Academia Española 2010, pp. 319-20) (1c). 
(1)

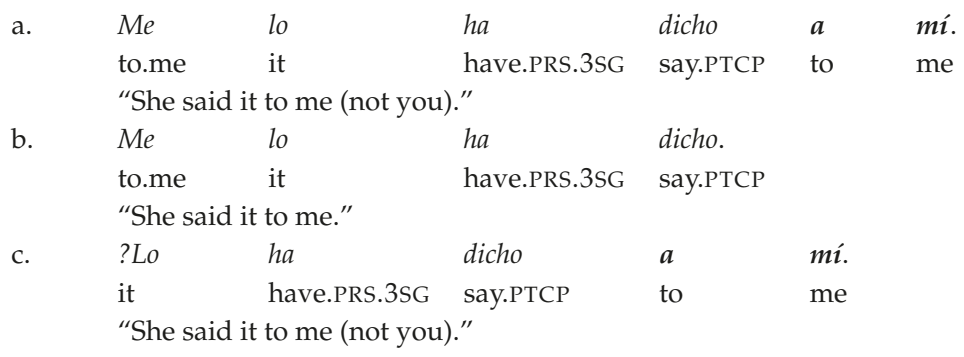

It is possible that not only the usage frequency of the refunctionalized forms, but also the usage frequency of the function they came to adapt had an influence on the realization of the refunctionalization process. As a basic information-structuring device, the use of focus is ubiquitous in Spanish (and many, if not all, other languages). In this sense, it might be possible to argue that there was a higher likelihood for speakers to use the distinction between focus and background as a model for the refunctionalization of the two types of personal pronouns than other, less frequent patterns in the language.

In line with these considerations, we can hypothesize that when an obsolescent construction is refunctionalized, the linguistic pattern that serves as a model for the new function occurs in a comparable usage context (i.e., there is some semantic similarity between the refunctionalized construction and the source pattern) and has a high usage frequency.

Hypothesis 2. When refunctionalizing a construction, speakers typically refer to patterns as models for the new function that (a) occur in comparable usage contexts and (b) have a high usage frequency.

\section{Folk Etymology as Refunctionalization}

As stated in the introduction, this paper aims at giving experimental proof for Hypotheses 1 and 2. In this section, I will argue that the process of folk etymology is an adequate testing ground for the study of the influence of usage frequency on refunctionalization. Blank (2001) defines folk etymology as

a type of reanalysis. Due to their formal phonetic similarity, speakers relate two words to each other. This reanalysis always contradicts the real etymology of the reanalyzed word. (Blank 2001, p. 91, transl. MR)

Olschansky (1996) gives a more detailed definition of folk etymology:

Folk etymology is a process in which a synchronically isolated and as such unmotivated word or word constituent is attributed to a word that is phonetically similar or (partially) identical [ ... ] in a way that is incorrect from an etymological and diachronic perspective. Consequently, the word or word constituent receives a new motivation and interpretation, and is de-isolated. (Olschansky 1996, p. 107, transl. MR)

The quote from Olschansky makes obvious that the type of reanalysis involved in refunctionalization is not syntactic but semantic reanalysis, i.e., a meaning change. To give an example, the German word Hebamme "midwife" derives from Old High German HEvianNA "old woman who lifts a child". Whereas the first part of the compound HEVI- remounts to the verb heben "lift," the origin and exact meaning of the second part of the compound -ANNA is unknown (Kluge 2003). In later times, the morpheme-ANNA was replaced with the German word Amme "nurse," leading to the creation of the Modern German word Hebamme "midwife".

The example illustrates that folk etymology is in the first place a formal change in that the phonetic substance of the target morpheme-ANNA is changed in accordance with the supposed etymon (Amme). 
Semantic factors are often irrelevant for this process as the meaning of the alleged etymon does not necessarily have to be compatible with the overall meaning of the target word, as shown by Maiden (2008, pp. 311-19). Consequently, "speakers are not seeking to 'explain' the meaning of a word, but to give it a familiar inner structure." (Maiden 2008, p. 315). In this way, folk etymology does not give a semantic motivation to (parts of) words. However, at least to some degree, folk etymology can be characterized as a refunctionalization process. Note that in our example, at least one of the morphemes forming the original no longer has a meaning in language and is in this sense devoid of a function. ${ }^{1}$ By substituting the morpheme with another morpheme, speakers arguably also confer the meaning of the alleged etymon to the resulting lexeme. As argued by Maiden (2008, p. 317), although the meaning of the morpheme butter is irrelevant for the meaning of the compound butterfly, upon hearing the compound butterfly, his "pre-theoretical native-speaker intuition about this compound is that the first element is the formative butter". The experimental studies in Libben and De Almeida (2002) and Jarema (2005, pp. 47-51) cited by Maiden confirm this intuition in that speakers appear to indeed parse formatives such as butter in butterfly as the word butter with its specific semantics. Returning to our example of German Hebamme, we can argue that the reanalysis of the original morpheme-ANNA did indeed lead to a refunctionalization of HEVIANNA in that it obtained a new semantics and consequently, function. It is in this sense that folk etymology serves the function of reincorporating "orphaned words" into the lexicon (Blank 2001, p. 92).

If folk etymology can be characterized as a kind of refunctionalization process, we can use it to test the two hypotheses on the influence of usage frequency on refunctionalization established in Section 2. Regarding the question of whether or not speakers will produce a folk etymology process, we can assume that the usage frequency of the reanalyzed element plays an important role. In many folk etymology processes, the reanalyzed element is no longer used independently in the language and its meaning is no longer identifiable. In other words, the element has been affected by an obsolescence process. In line with Hypothesis 1 established in Section 2, this makes the prediction that participants are more likely to accept the false etymology if the target word has a low usage frequency.

We can also try to make predictions regarding the elements that are used as models for the reanalyzed element in folk etymologies. As suggested by the studies cited above, speakers typically select false etymons that bear a phonological resemblance to the target morpheme. A second prediction is therefore that folk etymology processes become more likely if there are elements that are formally similar to the target morpheme. However, we can also assume an influence of usage frequency in that, in line with Hypothesis 2, speakers are more likely to establish a false etymology if the alleged etymon has a high usage frequency.

\section{Questionnaire Study}

In this section, I describe the exploratory questionnaire study ${ }^{2}$ conducted in order to test Hypotheses 1-2.

\subsection{Materials}

The questionnaire study aimed at establishing the influence of usage frequency on folk etymology processes, and consequently, refunctionalization processes, in Modern Spanish. Speakers were presented with a target word from Modern Spanish. They were then presented with an invented, false etymon for this target word and asked whether they thought it possible that the target word derived from the alleged etymon. ${ }^{3}$ They were given three possible answers: "Yes," "No," and "I don't know

\footnotetext{
Indeed, instances such as this one might be the closest to Lass' (1990) notion of junk morphology that can be found in a language.

2 All participants were informed about the aims of the study and the anonymity of their responses, and they provided their consent.

3 It would, of course, have been possible to also include factual etymologies as a control group, or even give the participants the choice between the false and the factual etymology. For the sake of simplicity of interpretation of the results, I did not consider this option in this experiment. However, I do believe that it would be viable in follow-up studies.
} 
the word(s)". In the case of the first answer, the participants thus accepted the folk etymology. In the case of the second answer, they rejected it. Cases in which the participants selected the third answer were eliminated from subsequent analysis.

I selected 30 Spanish target words on the basis of Dworkin (2012). The selection process was mostly guided by the possibility of finding a possible false etymon that was phonologically and semantically plausible for the participants of the experiment. An entire list of the materials can be found in the Appendix A (Table A1). I extracted the usage frequency (per million words) of each of the target words and the proposed etymons from the 20th century part of the Corpus del Español (Davies 2002, over 20 million words).

\subsection{Procedure}

I created a questionnaire on Google Docs that is available in its entirety in the Appendix A (Table A2). The questionnaire was structured in four parts. After a brief introduction (Part 1), in Part 2 the participants were given a number of background questions about their sex, age, native tongue, and education. In Part 3, the participants were presented with the 30 questions about the target words. The order of the questions was randomized in order to neutralize priming effects. The questionnaire closed with a brief confirmation text (Part 4).

The questionnaire was distributed via Facebook, several classes in the Humanities Departments at the Universitat de Barcelona, as well as classes organized by the Consejo Superior de Investigaciones Científicas (CSIC) in Madrid. Sixty-seven participants took part in the questionnaire study, of which 42 were female and 25 were male. The results from 11 participants that were not native speakers of Spanish were judged unreliable and therefore eliminated from subsequent analysis, leaving a total of 56 participants.

\subsection{Results}

When analyzing the results from the questionnaire study, I detected an unexpected and unwanted strong positive correlation between the usage frequencies of the target words and the usage frequencies of the proposed etymons $\left(\mathrm{r}=0.79, p<0.001^{* * *}\right)$. A closer look at the distribution of the two frequency measures shows that this correlation hinged on the target word mañana "tomorrow", for which the false etymon año "year" was given. While mañana has by far the highest usage frequency of all target words, año by far has the highest usage frequency of all of proposed etymons (see Figure 1). Mañana can therefore be characterized as an outlier.
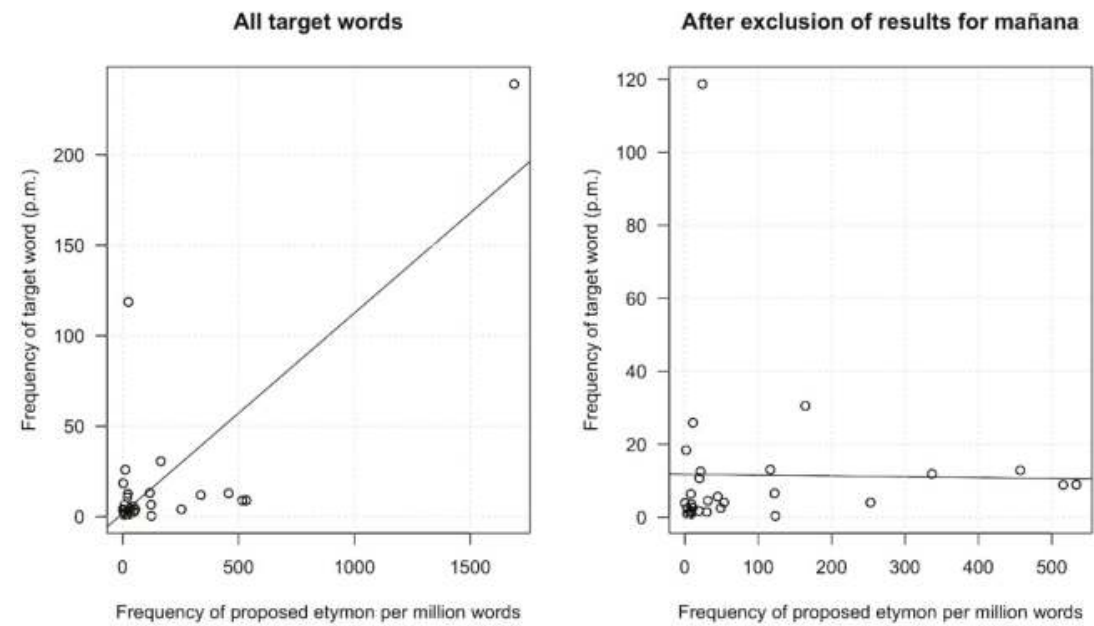

Figure 1. Correlation between the usage frequencies of the target words and the proposed etymons. 
Since (a) I aimed at including both usage frequency of target words and usage frequency of proposed etymon as predictor variables in a logistic regression analysis, and (b) it is a prerequisite for logistic regression analyses that the predictor variables be independent from each other, I eliminated the results for the target word mañana from the analysis. This procedure also eliminated the correlation between the two predictor variables in the data (see the right plot in Figure 1). I therefore did not eliminate the results for the target word prensa, which also has a high usage frequency (118.7 p.m.), from the data. See Figure A1 in the Appendix A for an overview of the frequencies of acceptance for each of the target words.

Mixed-effects regression models (Baayen 2008, chp. 7; Pinheiro et al. 2018) are an adequate tool for the analysis of data from experiments such as questionnaire studies. The quality of experimental data frequently suffers from the fact that the group of experiment participants is a random sample from the global population. Each of these participants may display idiosyncrasies regarding the variable investigated in the experiment. In the case of this questionnaire study, some participants were overall more likely to answer YES to the questions about the etymology posed to them than other participants, a fact that our predictor variables, such as usage frequency, cannot explain. Mixed-effects regression models address this problem by including both fixed effects (the traditional predictors, i.e., repeatable factors) and random effects (variables such as participant, which are not repeatable). In addition to calculating the coefficients for the predictor variables, a mixed-effects regression model will calculate a random intercept for each level of the random variables, thus greatly enhancing the statistical resolution and controlling for unwanted variation due to the fact that the participants were chosen randomly and might display individual preferences.

I calculated a logistic mixed-effects regression model in R ( $R$ Development Core Team 2015) over the responses of the participants to the questions regarding the etymology of the target words (variable REFUNCTION with the outcomes "yes" or "no"). The random variable was PARTICIPANT, allowing the model to control for interpersonal variation. Table 1 summarizes the predictor variables used in the model. I decided not to include a variable measuring the education of the participants because a large majority had university education. I did however include variables referring to the length of the target words and proposed etymons (TW.LETTERS and PE.LETTERS), as well as an interaction effect between the two variables as an approximant of the importance of formal similarity between target words and proposed etymons.

Table 1. Summary of predictor variables.

\begin{tabular}{ccc}
\hline Variable Name & Short Description & Levels \\
\hline AGE & Age of participant & $<20,20-30,>31$ \\
\hline SEX & Sex of participant & $\mathrm{f}, \mathrm{m}$ \\
\hline LINGUIST & $\begin{array}{c}\text { Whether or not the participant has } \\
\text { university education in linguistics }\end{array}$ & yes, no \\
\hline TW.LETTERS & Length of target word in letters & (numeric, z-standardized) \\
\hline TW.FREQUENCY & $\begin{array}{c}\text { Length of proposed etymon in } \\
\text { letters }\end{array}$ & $\begin{array}{c}\text { (numeric, } \mathrm{z} \text {-standardized) } \\
\text { million }\end{array}$ \\
\hline PE.FREQUENCY & $\begin{array}{c}\text { Frequency of proposed etymon } \\
\text { word per million }\end{array}$ & (numeric, z-standardized) \\
\hline
\end{tabular}

In the following description of the results from the regression model, I provide plots of the effects because these are easier to interpret for readers without knowledge of regression models. The full results from the regression model can be found in the Appendix A (Table A3). The effect plots were created using the package <effects $>$ in R. 
With a c index of concordance $=0.74$, the model reaches a rather moderate fit to the data that hints at the fact that important factors are missing from the analysis that explain the participants' decisions in the survey. ${ }^{4}$

\subsubsection{Social Indicators}

Of the social indicators, only the variable LINGUIST had a significant effect on the participants' choices. AGE and SEX appeared to be irrelevant. As illustrated in the effect plot (Figure 2), participants with a knowledge of linguistics were significantly more skeptical regarding the proposed etymologies.

\section{Linguist effect plot}

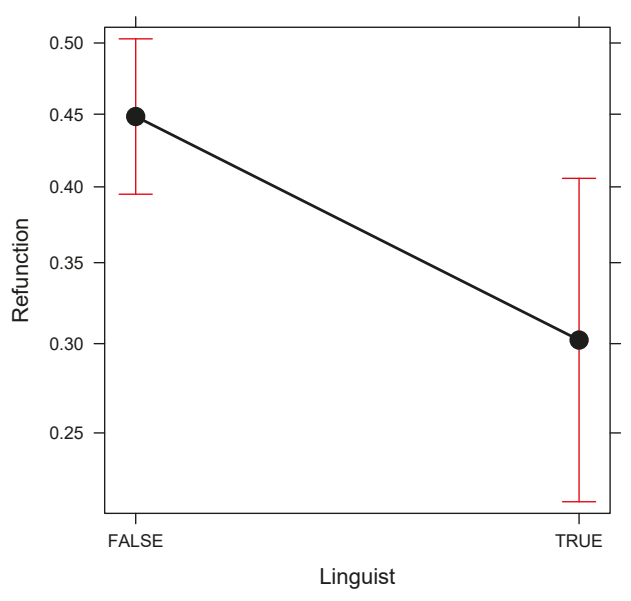

Figure 2. Effect plot for LINGUIST.

\subsubsection{Length of Target Word and Proposed Etymon}

Interestingly, both the length of the target word and the proposed etymon in letters had significant and differing effects on the participants' judgment on the proposed etymologies. Whereas participants were more likely to accept the false etymology when the target word was longer (Figure 3, left plot), for longer proposed etymons, they were less likely to accept the false etymology (Figure 3, right plot). ${ }^{5}$

4 See, for instance, Baayen (2008, p. 244), who claims that "a value above 0.8 indicates that model may have some real predictive capacity".

5 Recall that the values for all numerical variables in the analysis were $z$-standardized. The values on the $x$-axis in all of the graphs in Figures 3-5 refer to these normalized values and not the original numerical values. 
TW.Letters effect plot

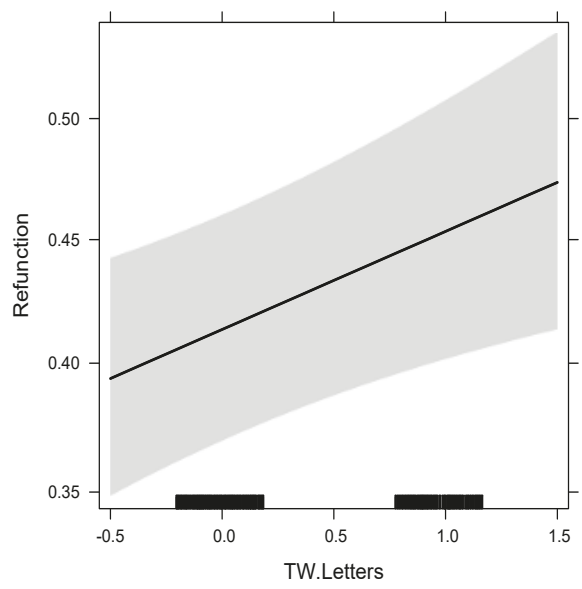

PE.Letters effect plot

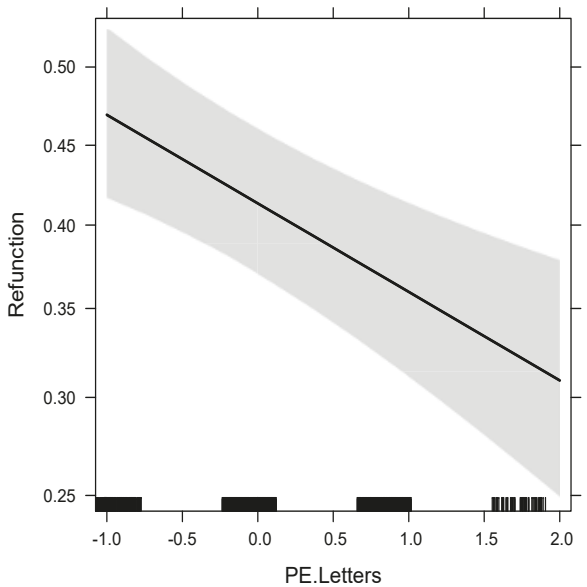

Figure 3. Effect plot for TW.LETTERS and PE.LETTERS.

Furthermore, the analysis demonstrated the existence of an interaction effect between the two word-length indicators. Figure 4 illustrates this moderating effect of TW.LETTERS on PE.LETTERS. The finding that shorter proposed etymons are judged to be better etymons was restricted to cases in which the target word was also short (the lines marked as -0.99 and -0.01 ). If the target word was long (the lines marked as 0.97 and 1.95), the effect was reversed; participants were more likely to accept longer proposed etymons than shorter proposed etymons.

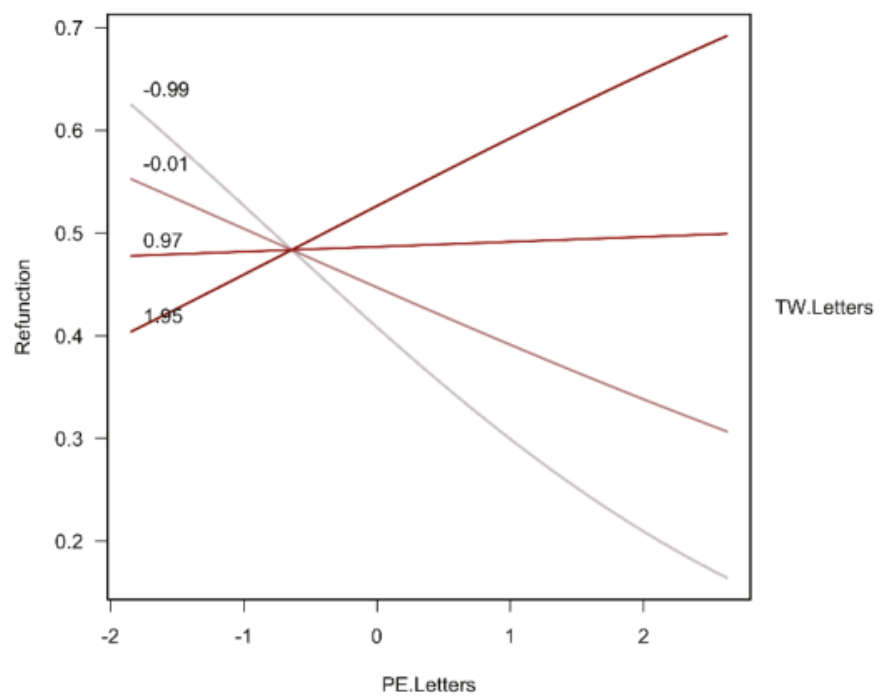

Figure 4. Effect plot for TW.LETTERS:PE.LETTERS (interaction effect). 


\subsubsection{Usage Frequency of Target Word and Proposed Etymon}

The regression did not find a significant effect for the usage frequency of the target word on the participants' judgments on the false etymology (see Figure 5, left plot). In contrast, there was a significant effect of the usage frequency of the proposed etymon (Figure 5, right plot). Thus, participants were significantly more likely to accept the false etymology for high-frequency false etymons than for low-frequency false etymons.
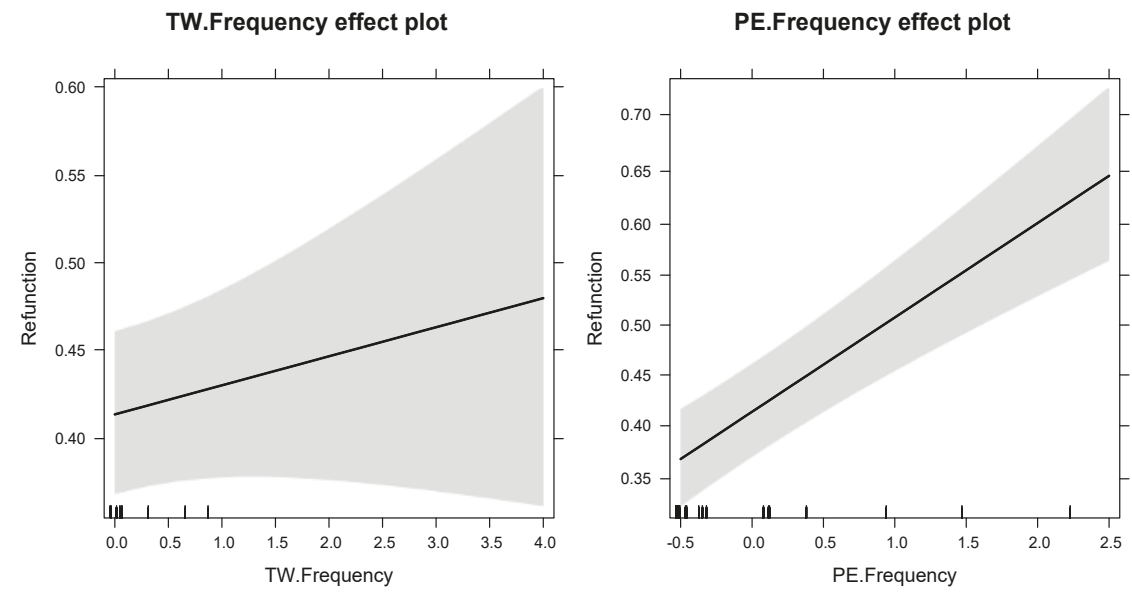

Figure 5. Effect plot for TW.FREQUENCY and PE.FREQUENCY.

\section{Discussion}

The results described in the last section confirm Hypothesis 2 in that participants were more likely to accept the false etymology when the proposed etymon was of high usage frequency than when it was of low frequency. This suggests that in processes of folk etymology, speakers will more frequently recur to high-frequency words than to low-frequency words as models. This observation is in line with usage-based approaches to language change; high-frequency words are more salient in a language than low-frequency words and therefore have a higher degree of cognitive accessibility than low-frequency words.

In contrast, Hypothesis 1-the assumption that refunctionalization and likewise, folk etymology processes, are more likely for low-frequency target forms than high-frequency target forms-was not confirmed in my analysis. This result can possibly be explained by the artificial experimental setup. Crucially, participants were only asked whether they accepted the false etymology for a target word. In real-life processes of folk etymology, speakers' motivations for folk etymology are very different. Given that the decision to produce a folk etymology process was, as it were, imposed on the participants, this might have influenced their decision processes regarding whether or not to accept the proposed etymology. In other words, the questionnaire rather measured which false etymons were judged to be better etymons than others than whether or not a folk etymology process should take place.

Additionally, the regression analysis suggested that folk etymology processes were more likely for shorter proposed etymon words and longer target words. It is well known that shorter words are typically more frequent and therefore have a higher degree of cognitive accessibility (Bybee 2010, pp. 20-21). Consequently, one could argue that the participants were more likely to accept shorter proposed etymons because of their higher degree of cognitive accessibility. However, given that the results for target words point in the opposite direction, it appears to me that it is incorrect to invoke cognitive accessibility as the relevant parameter. Rather, it appears that the participants have 
an understanding (either intuitive or due to their training as linguists) that due to derivation or composition processes, words that are historically derived from certain source words tend to be longer than these source words.

The interaction effect between the length of the target word and the length of the proposed etymon analysis appears to reveal that structural similarity also had an influence on the participants' decisions to accept a proposed etymology. Participants were more likely to accept a proposed etymology if (a) both the target word and the proposed etymon were short or (b) both the target word and the proposed etymon were long.

On a final note, the regression model was not able to explain much of the variance in the results, as indicated by the relatively low value of the $\mathrm{c}$ index of concordance. This lack of statistical resolution suggests that the analysis was lacking crucial parameters. In particular, there were no parameters measuring the degree of formal and semantic similarity between the target words and the proposed etymons. It seems likely that by including psycholinguistics measurements of the degree of similarity between these items it would be possible to greatly enhance the statistical resolution of the analysis and uncover more effects on the participants' behavior in the questionnaire survey.

\section{Conclusions}

In this paper, I hypothesized that usage frequency plays an important role in refunctionalization processes in that refunctionalization is more likely for low-frequency constructions than high-frequency constructions (Hypothesis 1), and that high-frequency constructions are better models for refunctionalization processes than low-frequency constructions (Hypothesis 2). I proposed that folk etymology can be regarded as a type of refunctionalization process and that it can therefore be used in order to empirically test these assumptions. The results from the questionnaire study on folk etymology supported some of the assumptions. In particular, participants were more likely to accept false etymons for the target words if the proposed etymons had a high usage frequency, confirming Hypothesis 2. The experiment was however not able to confirm Hypothesis 1. I also found an effect of the length of the target word, as well as the length of the proposed etymon. It was also found that participants with a background in linguistics fared significantly better in the survey than participants without knowledge of linguistics.

It must be noted that these findings are preliminary and should therefore be taken with caution. In particular, the low degree of variance explained by the regression analysis indicates that the study was missing crucial parameters that may relativize some of the results from the analysis. Further studies on the reasons for folk etymology processes should consider including psycholinguistic measurements of the degree of formal and semantic similarity between target words and proposed etymons. These measurements might also provide the experimenter with a more principled way of selecting the stimuli. Lastly, there might be experiment types that are better suited than questionnaire studies for such an analysis. One could, for instance, imagine an experiment in which the reaction of participants to false etymologies is measured using reading times or even fMRI. Longer reaction times should then indicate more problems with the acceptance of the false etymology. Such response types would serve to diminish the degree to which participants actively contemplate the likelihood of the proposed etymology, and consequently increase the reliability of the experimental results.

Funding: This research received no external funding.

Conflicts of Interest: The author declares no conflict of interest. 


\section{Appendix A}

Table A1. Target words and proposed etymons.

\begin{tabular}{|c|c|c|}
\hline Target Word & Etymology (Dworkin 2012; Real Academia Española 2014) & Proposed Etymon \\
\hline $\begin{array}{l}\text { Acechar } \\
\text { "to stalk" }\end{array}$ & lat. * ASSECTARE “attend to" (Dworkin 2012, p. 102) & $\begin{array}{l}\text { echar } \\
\text { "to throw" }\end{array}$ \\
\hline $\begin{array}{l}\text { achacar } \\
\text { "to blame" }\end{array}$ & arab. TASAKKA “blame” (Dworkin 2012, p. 102) & $\begin{array}{l}\text { atacar } \\
\text { "to attack" }\end{array}$ \\
\hline ademán "gesture" & arab. AD-DAMAN “legal guarantee” (Dworkin 2012, p. 46) & $\begin{array}{l}\text { Mano } \\
\text { "hand" }\end{array}$ \\
\hline $\begin{array}{l}\text { adorar } \\
\text { "to adore" }\end{array}$ & lat. AD-ORARE "towards-pray" (Dworkin 2012, p. 161) & $\begin{array}{l}\text { oro } \\
\text { "gold" }\end{array}$ \\
\hline albañil "bricklayer" & arab. AL-BANNA "the construer" (Dworkin 2012, p. 112) & $\begin{array}{c}\text { Baño } \\
\text { "bathroom" }\end{array}$ \\
\hline almirante "admiral" & arab. AMÎR "commander" (Dworkin 2012, p. 90) & $\begin{array}{c}\text { mirar } \\
\text { "to look" }\end{array}$ \\
\hline $\begin{array}{l}\text { alojar } \\
\text { "to lodge" }\end{array}$ & sp. LONJA “portico, porch" (Dworkin 2012, p. 146) & $\begin{array}{l}\text { lugar } \\
\text { "place" }\end{array}$ \\
\hline $\begin{array}{c}\text { amainar } \\
\text { "to weaken, flag" }\end{array}$ & goth. AF-MAGINON “lower the sails” (Dworkin 2012, p. 72) & marginal "marginal" \\
\hline $\begin{array}{l}\text { apagar } \\
\text { "to turn off" }\end{array}$ & lat. PACARE "pacify, quiet" (Dworkin 2012, p. 55) & $\begin{array}{l}\text { pagar } \\
\text { "to pay" }\end{array}$ \\
\hline azafata "stewardess" & arab. AL-SAFÁT “basket” (Dworkin 2012, p. 109) & $\begin{array}{l}\text { zarpar } \\
\text { "to set sails" }\end{array}$ \\
\hline bagaje "baggage" & fr. BAGAGE "baggage" (Dworkin 2012, p. 127) & $\begin{array}{l}\text { vagar } \\
\text { "to wander" }\end{array}$ \\
\hline $\begin{array}{l}\text { barrer } \\
\text { "to sweep" }\end{array}$ & lat. VERRERE "sweep" (Dworkin 2012, p. 46) & $\begin{array}{c}\text { barro } \\
\text { "mud" }\end{array}$ \\
\hline bigote "mustache" & ger. BEI GoTT “with god” or fr. BIGOT (Dworkin 2012, pp. 77-78) & $\begin{array}{l}\text { gota } \\
\text { "drop" }\end{array}$ \\
\hline bisoño "greenhorn" & it. BISOGNO “need" (Dworkin 2012, pp. 151-52) & $\begin{array}{c}\text { sueño } \\
\text { "dream" }\end{array}$ \\
\hline bochorno "extreme heat" & lat. VULTURNUS “south wind” (Dworkin 2012, p. 49) & $\begin{array}{l}\text { horno } \\
\text { "oven" }\end{array}$ \\
\hline borrasca "storm (at sea)" & probably it. BURRASCA "storm" (Dworkin 2012, p. 145) & $\begin{array}{l}\text { rascar } \\
\text { "to scratch" }\end{array}$ \\
\hline $\begin{array}{l}\text { bostezar } \\
\text { "to yawn" }\end{array}$ & lat. OSCITARE "open the mouth wide" (Dworkin 2012, p. 52) & $\begin{array}{l}v o z \\
\text { "voice" }\end{array}$ \\
\hline $\begin{array}{c}\text { carabela } \\
\text { "type of ship" }\end{array}$ & 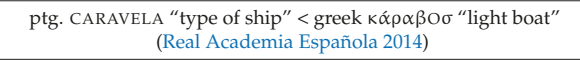 & $\begin{array}{l}\text { vela } \\
\text { "to sail" }\end{array}$ \\
\hline $\begin{array}{l}\text { cerveza } \\
\text { "beer" }\end{array}$ & celtic CERVISIA “beer” (Dworkin 2012, p. 28) & $\begin{array}{l}\text { hervir } \\
\text { "to boil" }\end{array}$ \\
\hline debilidad "weakness" & $\begin{array}{l}\text { fr. DEBILITÉ "weakness" (Dworkin 2012, p. 132) < PIE *BEL } \\
\text { "power, strength" }\end{array}$ & $\begin{array}{c}\text { bilis } \\
\text { "bile" }\end{array}$ \\
\hline despejado "cloudless" & ptg. DESPEJAR “pour" (Dworkin 2012, p. 188) & $\begin{array}{l}\text { espejo } \\
\text { "mirror" }\end{array}$ \\
\hline $\begin{array}{l}\text { enojar } \\
\text { "anger" }\end{array}$ & o.provenz. ENOJAR “anger” (Dworkin 2012, p. 125) & $\begin{array}{c}\text { ojo } \\
\text { "eye" }\end{array}$ \\
\hline escopeta "shotgun" & it. SCHIPETTO “firearm" (Dworkin 2012, p. 152) & $\begin{array}{l}\text { escupir } \\
\text { "to spit" }\end{array}$ \\
\hline $\begin{array}{c}\text { esgrimir } \\
\text { "to wield a weapon" }\end{array}$ & o.provenz. ESGREMIR “wield a weapon" (Dworkin 2012, p. 125) & $\begin{array}{l}\text { grima } \\
\text { "chills" }\end{array}$ \\
\hline $\begin{array}{c}\text { eslabón } \\
\text { "link (of a chain)" }\end{array}$ & goth. SNÔBÔ “link” (Dworkin 2012, p. 72) & $\begin{array}{c}\text { eslavo } \\
\text { "slave" }\end{array}$ \\
\hline $\begin{array}{l}\text { espuela } \\
\text { "spur" }\end{array}$ & goth. SPAÚRA "spur" (Dworkin 2012, p. 71) & $\begin{array}{c}\text { esposo } \\
\text { "husband" }\end{array}$ \\
\hline $\begin{array}{c}\text { iguana } \\
\text { "type of saurian" }\end{array}$ & taíno IGUANA "type of saurian" (Dworkin 2012, p. 200) & $\begin{array}{l}\text { guante } \\
\text { "glove" }\end{array}$ \\
\hline $\begin{array}{c}\text { jarabe } \\
\text { "syrup" }\end{array}$ & arab. SHARB "syrup" (Dworkin 2012, p. 84) & $\begin{array}{l}\text { jarro } \\
\text { "jug" }\end{array}$ \\
\hline mañana "morning" & v.lat. "MANEANA “morning" (Dworkin 2012, p. 56) & $\begin{array}{c}\text { año } \\
\text { "year" }\end{array}$ \\
\hline $\begin{array}{l}\text { prensa } \\
\text { "press" }\end{array}$ & cat. PREMER "press, squeeze" (Dworkin 2012, p. 194) & $\begin{array}{l}\text { prender } \\
\text { "to take" }\end{array}$ \\
\hline
\end{tabular}


Table A2. Questionnaire design.

\begin{tabular}{l} 
Original Text \\
\hline 1. Introduction \\
¡Hola! Muchas gracias por cooperar en nuestro \\
EtimoTest. Pretendemos examinar el conocimiento \\
que tienen de la etimología—el origen de las \\
palabras—los hablantes nativos del español. \\
A menudo, las nuevas palabras se basan en otras \\
palabras ya existentes en la lengua. Por ejemplo, el \\
adjetivo barato deriva del verbo baratar ("trocar, \\
comprar a bajo precio"). La palabra escarnimiento \\
(“desengaño") deriva del antiguo verbo escanir \\
(“hacer burla de alguien”). A veces tenemos una \\
intuición sobre la palabra que fue la base para una \\
nueva palabra; otras veces, en cambio, no la tenemos.
\end{tabular}

Para examinar tu nivel de conocimiento de la etimología de las palabras, te presentaremos 30 palabras españolas. Para cada de una de ellas, te ofrecemos una palabra base como solución. En algunos casos, esta palabra es la palabra base correcta; en otros casos, no. Te preguntaremos si es posible que la palabra derive de la palabra base, y te daremos tres opciones: SÍ, NO, y NO CONOZCO LA(S)

PALABRA(S). Por favor, selecciona esta última opción solo si no conoces una de las palabras. En total, el EtimoTest dura alrededor de 10 minutos.

Un aviso importante: por favor rellena el cuestionario sin utilizar recursos como diccionarios, google, etc. Así invalidarías los resultados de tu EtimoTest.

Antes de empezar, tenemos que hacerte unas breves preguntas sobre tu persona. Te garantizamos que tus respuestas van a ser tratadas con la máxima discreción.

\section{Background questions}

2.1 ¿Cuál es tu sexo?

Femenino

Masculino

2.2 ¿Cuál es tu edad?

Menos de 20 años

Entre 20 y 30 años

Más de 30 años

2.3 ¿Eres hablante nativo del español? Sí

No

2.4 ¿Cuál es tu nivel de educación?

Estudios Primarios

Educación Secundaria Obligatoria

Bachillerato

Educación secundaria post obligatoria

Estudios universitarios

(Grado/Máster/Posgrado/Doctorado)

2.5 Sí estás realizando/has realizado estudios universitarios, ¿cuál era la asignatura/las asignaturas?
English Translation

\section{Introduction}

Hi! Thank you very much for participating in our EtimoTest. We want to investigate the knowledge of etymology — the origin of words — of native speakers of Spanish.

Frequently, new words are based on other words that already exist in a language. For instance, the adjective barato "cheap" derives from the verb baratar "to bargain, buy at a cheap price". The words escarnimiento "punishment" derives from the old verb escanir "make fun of somebody". Sometimes we have an intuition about which word served as a basis for the new word, sometimes we do not.

In order to examine your level of knowledge of the etymology of words, we will present you with 30 Spanish words. For each one of these, we offer you an origin word as a solution. In some cases, this word is the correct origin word, in some cases it is not. We will ask you if it is possible that the word derives from the origin word, and we will give you three options: YES, NO, and I DO NOT KNOW THE WORD(S). Please select this last option only if you do not know one of the words. The EtimoTest will last around $10 \mathrm{~min}$.

One important point: please fill out the questionnaire without using dictionaries, Google, etc. In doing so, you would invalidate the results of your EtimoTest.

Before we begin, we have to ask you a few questions about yourself. We guarantee you that your answers will be treated with maximal discretion.

\section{Background questions}

2.1 What is your sex?

Feminine

Masculine

2.2 What is your age?

Less than 20 years

Between 20 and 30 years

More than 30 years

2.3 Are you a native speaker of Spanish?

Yes

No

2.4 What is your level of education?

Estudios Primarios

Educación Secundaria Obligatoria

Bachillerato

Educación secundaria post obligatoria

Estudios universitarios

(Grado/Máster/Posgrado/Doctorado)

2.5 If you are studying/have studied at a university, what was the study subject? 
Table A2. Cont.

\begin{tabular}{|c|c|}
\hline Original Text & English Translation \\
\hline 3. Test & 3. Test \\
\hline $\begin{array}{l}\text { ¿Es posible que la palabra [TARGET] derive de la } \\
\text { palabra [PROPOSED ETYMON]? }\end{array}$ & $\begin{array}{l}\text { Is it possible that the word [TARGET] derives from } \\
\text { the word [PROPOSED ETYMON]? }\end{array}$ \\
\hline Sí & Yes \\
\hline No & No \\
\hline No conozco la(s) palabra(s) & I do not know the word(s) \\
\hline [30 questions in total, randomized order] & [30 questions in total, randomized order] \\
\hline 4. Confirmation text & 4. Confirmation text \\
\hline $\begin{array}{l}\text { Esta ha sido la última pregunta. ¡Muchas gracias por } \\
\text { tu participación en el EtimoTest! }\end{array}$ & $\begin{array}{l}\text { This has been the last question. Thank you very much } \\
\text { for your participation in the EtimoTest! }\end{array}$ \\
\hline
\end{tabular}

Table A3. Full results from the logistic regression model.

\begin{tabular}{|c|c|c|c|c|c|c|c|}
\hline Variable & Level & Betas & Odds & SE & ZVAL & \multicolumn{2}{|c|}{$p$} \\
\hline \multicolumn{2}{|c|}{ (Intercept) } & 0.00 & 1.00 & 0.30 & 0.10 & 0.994 & \\
\hline \multirow{3}{*}{ AGE } & $<20$ & \multicolumn{5}{|c|}{ Reference level } & \\
\hline & $21-30$ & -0.18 & 0.84 & 0.31 & -0.58 & 0.562 & \\
\hline & $>31$ & -0.44 & 0.64 & 0.32 & -1.39 & 0.164 & \\
\hline \multirow{2}{*}{ SEX } & Feminine & \multicolumn{5}{|c|}{ Reference level } & \\
\hline & Masculine & 0.15 & 1.16 & 0.20 & 0.74 & 0.458 & \\
\hline \multirow{2}{*}{ LINGUIST } & FALSE & \multicolumn{5}{|c|}{ Reference level } & \multirow[b]{2}{*}{ * } \\
\hline & TRUE & -0.63 & 0.53 & 0.27 & -2.33 & 0.020 & \\
\hline \multicolumn{2}{|c|}{ TW.LETTERS } & 0.16 & 1.18 & 0.06 & 2.86 & 0.004 & $* *$ \\
\hline \multicolumn{2}{|c|}{ PE.LETTERS } & -0.23 & 0.80 & 0.06 & 3.77 & 0.000 & $* * *$ \\
\hline \multicolumn{2}{|c|}{ TW.FREQUENCY } & 0.07 & 1.07 & 0.06 & 1.17 & 0.243 & \\
\hline \multicolumn{2}{|c|}{ PE.FREQUENCY } & 0.38 & 1.46 & 0.06 & 6.35 & 0.000 & $* * *$ \\
\hline \multicolumn{2}{|c|}{$\begin{array}{l}\text { TW.LETTERS: } \\
\text { PE.LETTERS }\end{array}$} & 0.25 & 1.29 & 0.07 & 3.77 & 0.000 & $* * *$ \\
\hline \multirow{6}{*}{\multicolumn{2}{|c|}{ MODEL EVALUATION }} & \multicolumn{6}{|c|}{ Number of observations $=1629$} \\
\hline & & \multicolumn{6}{|c|}{$\mathrm{C}$ index of concordance $=0.74$} \\
\hline & & \multicolumn{6}{|c|}{ Somers' $\mathrm{dxy}=0.47$} \\
\hline & & \multicolumn{6}{|c|}{$\mathrm{AIC}=2082.2$} \\
\hline & & \multicolumn{6}{|c|}{$\mathrm{BIC}=2141.5$} \\
\hline & & \multicolumn{6}{|c|}{$p$ values: $^{*}=<0.05,{ }^{* *}=<0.01,{ }^{* * *}=<0.001$} \\
\hline
\end{tabular}

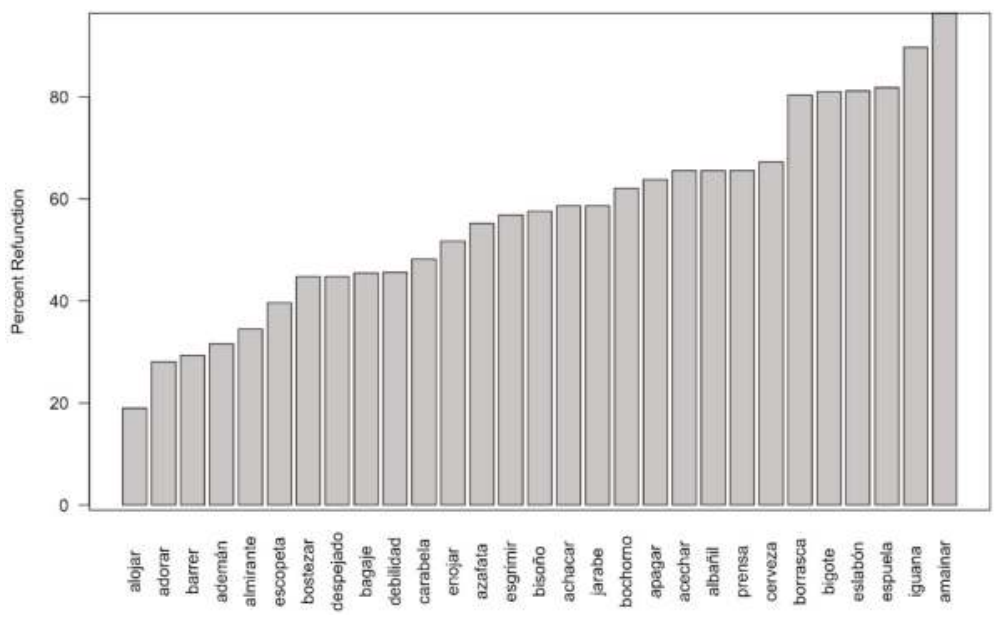

Figure A1. Proportion of accepted proposed etymologies by target words. 


\section{References}

Baayen, Harald. 2008. Analyzing Linguistic Data. A Practical Introduction to Statistics Using R. Cambridge: Cambridge University Press.

Blank, Andreas. 2001. Einführung in die lexikalische Semantik für Romanisten. Tübingen: Niemeyer.

Bybee, Joan L. 2006. From usage to grammar: The mind's response to repetition. Language 82: 711-33. [CrossRef]

Bybee, Joan L. 2010. Language, Usage, and Cognition. Cambridge: Cambridge University Press.

Davies, Mark. 2002. Corpus del Español (100 Million Words, 1200s-1900s). Available online: http://www. corpusdelespanol.org (accessed on 22 December 2015).

De Smet, Hendrik. 2012. The course of actualization. Language 88: 601-33. [CrossRef]

Dworkin, Steven N. 2012. A History of the Spanish Lexicon: A Linguistic Perspective. Oxford: Oxford University Press.

Jarema, Gonia. 2005. Compound representation and processing: A cross-language perspective. In Representation and Processing of Compound Words. Edited by Gary Libben and Gonia Jarema. Oxford: Oxford University Press, pp. 45-70.

Kluge, Friedrich. 2003. Etymologisches Wörterbuch der deutschen Sprache. Berlin: De Gruyter.

Lass, Roger. 1990. How to do things with junk: Exaptation in language evolution. Journal of Linguistics 1: 79-102. [CrossRef]

Libben, Gary, and Roberto G. De Almeida. 2002. Is there a morphological parser? In Morphology 2000. Edited by Sabrina Bendjaballah, Wolfgang U. Dressler, Oskar E. Pfeiffer and Maria D. Voeikova. Amsterdam and Philadelphia: John Benjamins, pp. 213-25.

Mackenzie, Ian. 2006. Unaccusative Verbs in Romance Languages. Basingstoke: Palgrave Macmillan.

Maiden, Martin. 2008. Lexical nonsense and morphological sense: On the real importance of 'folk etymology' and related phenomena for historical linguists. In Grammatical Change and Linguistic Theory: The Rosendal Papers. Edited by Thórhallur Eythórsson. Amsterdam and Philadelphia: John Benjamins, pp. 307-28.

Narrog, Heiko. 2016. Exaptation in Japanese and beyond. In Exaptation and Language Change. Edited by Muriel Norde and Freek Van de Velde. Amsterdam and Philadelphia: John Benjamins, pp. 93-120.

Norde, Muriel. 2009. Degrammaticalization. Oxford: Oxford University Press.

Norde, Muriel, and Freek Van de Velde, eds. 2016. Exaptation. Taking stock of a controversial notion in linguistics. In Exaptation and Language Change. Amsterdam and Philadelphia: John Benjamins, pp. 1-35.

Olschansky, Heike. 1996. Volksetymologie. Berlin: De Gruyter.

Pinheiro, Jose, Douglas Bates, Saikat DebRoy, Deepayan Sarkar, and the R Development Core Team. 2018. nlme: Linear and Nonlinear Mixed Effects Models, R Package Version 3.1-137; Available online: https:/ CRAN.Rproject.org $/$ package=nlme (accessed on 23 October 2018).

Poplack, Shana. 2001. Variability, frequency, and productivity in the irrealis domain of French. In Frequency and the Emergence of Linguistic Structure. Edited by Joan L. Bybee and Paul J. Hopper. Amsterdam and Philadelphia: John Benjamins, pp. 405-28.

Poplack, Shana, Allison Lealess, and Nathalie Dion. 2013. The evolving grammar of the French subjunctive. Probus 25: 139-95.

R Development Core Team. 2015. R: A Language and Environment for Statistical Computing. Vienna: R Foundation for Statistical Computing, Available online: http:/ / www.R-project.org (accessed on 26 December 2015).

Real Academia Española. 2010. Nueva gramática de la lengua española. Manual. Madrid: Escasa Libros.

Real Academia Española. 2014. Diccionario de la lengua española. Madrid: Real Academia Española.

Rodríguez Molina, Javier. 2006. Ser + participio en español antiguo: Perífrasis resultativa, no tiempo compuesto. In Actas del VI Congreso Internacional de Historia de la Lengua Española. Edited by José J. Bustos Tovar and José L. Girón Alchonchel. Madrid: Arco Libros, vol. II, pp. 1059-72.

Rosemeyer, Malte. 2014. Auxiliary Selection in Spanish. Gradience, Gradualness, and Conservation. Amsterdam and Philadelphia: John Benjamins.

Smith, John C. 2006. How to do things without junk. The refunctionalization of a pronominal subsystem between Latin and Romance. In New Perspectives on Romance Linguistics: Vol. II: Phonetics, Phonology and Dialectology. Selected Papers from the 35th Linguistic Symposium on Romance Languages (LSRL), Austin, Texas, February 2005. Edited by J. Montreuil. Amsterdam and Philadelphia: John Benjamins, pp. 183-205. 
Willis, David. 2010. Degrammaticalization and obsolescent morphology: Evidence from Slavonic. In Grammaticalization: Current Views and Issues. Edited by Ekatherini Stathi, Elke Gehweiler and Ekkehard König. Amsterdam and Philadelphia: John Benjamins, pp. 151-78.

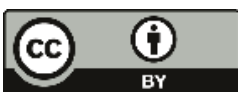

(C) 2018 by the author. Licensee MDPI, Basel, Switzerland. This article is an open access article distributed under the terms and conditions of the Creative Commons Attribution (CC BY) license (http:/ / creativecommons.org/licenses/by/4.0/). 
Article

\title{
Exaptation, Refunctionalization, Decapitalization-BE + Past Participle with Intransitive Verbs in Mediaeval and Early Modern Spanish
}

\begin{abstract}
Rolf Kailuweit
Department of Romance Philology, Heinrich-Heine University, 40225 Düsseldorf, Germany; kailuwei@hhu.de Received: 9 October 2018; Accepted: 1 November 2018; Published: 14 November 2018

Abstract: The chapter presents the current state of research concerning the development of the $\mathrm{BE}+$ past participle constructions from Latin to Spanish. Starting from the description in Rosemeyer (2014) and the theoretical background collated in Kailuweit and Rosemeyer (2015), it will be shown that the functional change does not follow traditional grammaticalization paths. Several concepts that deal with cases contradicting traditional grammaticalization theory will be discussed. 'Exaption' (Lass 1990, 1997), focusing on total defunctionalization does not account for the fact that the resultative value of the $\mathrm{BE}+$ past participle construction, marginal in Latin, becomes central in Mediaeval Spanish. 'Refunctionalization' Smith $(2008,2011)$ captures this aspect in a more appropriate way. However, the development of the construction could be also conceived as the opposite of what Pountain (2000) describes as 'capitalization': a process of 'decapitalization,' by which a feature is exploited, not for wider, but for more restricted purposes.
\end{abstract}

Keywords: past participle construction; auxiliaries; resultatives; exaptation; refunctionalization; capitalization

\section{Introduction}

The formation of compound tenses in Romance languages with the periphrasis HAVE + past participle has been considered a prototypical case of grammaticalization (Schwenter 1994; Squartini and Bertinetto 2000; Detges 2001), following a grammaticalization path that seems to be universal (Bybee et al. 1994). In line with Harris (1982), Detges (2001) pointed out that four stages have to be distinguished. At the first stage, the value of the construction is resultative, marking the present state resulting from past action. At the second stage, the construction marks a continuous or repeated series of events that started in the past. At the third stage, the construction refers to a past event with present relevance (anteriors in Bybee et al.'s 1994 terminology) and at the fourth stage, it attains an aorist function denoting a past event without present relevance. While in standard Spanish HABER + past participle has only reached the third stage, AVOIR + past participle in spoken French has gone further on to the fourth stage, taking over the function of the simple past that is excluded from oral registers.

As far as the development of BE + past participle from Latin to Romance languages is concerned, the situation is quite complex. At first glance, there is no change at all. The structure BE + past participle already exists in classical Latin, expressing perfect passive (amatus est) and the perfect of the so-called deponent verbs (locutus est, profectus est) (Vincent 1982, pp. 85-86). According to Vincent (ibid., p. 86), these verbs favored "the development of periphrastic expressions like *ven(u)tum est," because etymologically they go back to medio-passives in Indo-European and, therefore, do not assign the role of a prototypical agent to their subject. Many deponent verbs denote a change of state that the 
subject-argument undergoes (gradior 'I step', morior 'I die', nascor 'I am born', etc.). Hence, a more or less formal and functional continuity from Latin to Romance, as far as BE + past participle is concerned, has been claimed in the literature (Yllera 1980; Vincent 1982; Harris 1982; Aranovich 2003).

However, Jacob (1994, pp. 363-65) pointed out that passive construction with BE + past participle in Romance languages has a presence-orientated resultative function incompatible with the preterite value of the formally analogous Latin periphrastic passive. According to Jacob (ibid., p. 365) and Mackenzie (2006, pp. 132-35) the same holds for deponent verbs. Jacob (ibid., p. 363) highlighted the fact that a regression from preterite to resultative would contradict all common grammaticalization theories. ${ }^{1}$

The objective of this short chapter is basically theoretical. I will cast some new light on the development of BE + past participle from Latin to Early Modern Spanish. I will do so by discussing some data I extracted from the CORDE-corpus, ${ }^{2}$ but essentially on the basis of the studies of Rosemeyer $(2014,2015)$ and, regarding Latin and Proto-Romance data, Cennamo (1997, 2001, 2008). My central claim is to take up the main topic of the present volume. Given a particular counter-example to the unidirectionality of a grammaticalization path, I shall discuss conceptual alternatives of description, for example, exaptation (Lass 1990, 1997; Narrog 2007), refunctionalization (Smith 2011) and capitalization (Pountain 2000).

\section{BE + Past Participle-A Criterion for Unaccusativity?}

In the last few decades, the fact that many modern European languages exhibit an alternation between the auxiliaries HAVE and BE in compound tenses of intransitive verbs has become a central topic of linguistic research. Starting with Perlmutter (1978) Unaccusative Hypothesis, ${ }^{3}$ auxiliary selection has been discussed as the main criterion for the distinction of an unaccusative (verbs selecting BE) and an unergative class (verbs selecting HAVE) (Alexiadou et al. 2004; Aranovich 2007; Kailuweit and Rosemeyer 2015). Although BE-selection is not a necessary criterion for unaccusativity, it is deemed a sufficient one. If we consider, in line with Sorace (2000) and Legendre and Sorace (2003), that unaccusativity is gradient, ${ }^{4}$ it is possible that BE-selection situates an intransitive verb nearer to the unaccusative pole (see Table 1).

BE-selection characterizes unaccusative core verbs, not only in modern Italian and French, but presumably in all languages using the BE/HAVE opposition to mark split-intransitivity in compound tenses. Having lost the use of $\mathrm{BE}+$ past participle in their standard varieties, Ibero-Romance languages seem to reflect the distribution of ETTRE/AVOIR we find in contemporary standard French (Kailuweit 2011, 2015) at the mediaeval and early modern stage. The most prototypical verbs occurring with $\mathrm{BE}+$ past participle are verbs of change of location and verbs of change of state, while verbs of controlled processes select exclusively HAVE. ${ }^{5}$ The following examples from Medieval Spanish may illustrate this contrast:

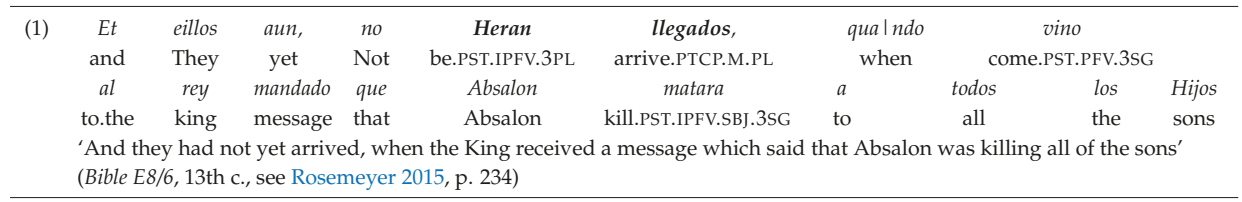

1 As Jacob (1994) pointed out, Herzog (1910, p. 136) has commented on the surprising fact that the use of the construction $\mathrm{BE}+$ past participle in the Mediaeval Romance languages seems to be a functional regression compared to its Latin origin.

2 Real Academia Española Corpus diacrónico del español. [http:/ / corpus.rae.es/cordenet.html].

3 This is not the place to give an exhaustive résumé of the discussion on 'unaccusativity'. See Levin and Hovav (1995); Alexiadou et al. (2004, eds.); Bentley and Eythórsson (2004); Mackenzie (2006).

4 This crucial insight from Sorace (2000) approach is taken up, for instance, in Bentley and Eythórsson (2004); Mateu (2009); Kailuweit (2011); and Rosemeyer (2014).

5 See Benzing (1931), Yllera (1980), Elvira (2001), Aranovich (2003) and Rosemeyer (2014) for Spanish, Cardoso and Pereira (2003) and Guilherme (2009) for Portuguese and Batlle (2002) and Mateu (2009) for Catalan. 


$\begin{array}{lccccccc}\text { (2) Quando } & \text { el } & \text { ouo } & \text { fablado } & \text { folgo } & \text { el } & \text { espiritu } & \text { Deillo } \\ \text { of.him }\end{array}$

The spread of HAVE in the history of Spanish seems to follow Sorace (2000) auxiliary selection hierarchy (Benzing 1931; Aranovich 2003; Mateu 2009; Rosemeyer 2014). However, the claim that earlier stages of Ibero-Romance languages code an opposition of unaccusativity and unergativity via auxiliary selection is based on the assumption that the BE + past participle and the HAVE + past participle construction with intransitive verbs are functionally equivalent, that is, instances of verbal perfect (anterior). As Mackenzie (2006) and Rosemeyer (2014) have shown, this assumption is by no means evident.

\section{ESSE + Past Participle $<$ SER + Past Participle}

In classical Latin, the periphrastic perfect of deponent verbs-as well as the perfect in general-has the main function of indicating the accomplished process, even if the result of this process is still given: ${ }^{6}$

Le perfectum [ ... ] correspond en gros à la valeur du parfait grec indiquant le résultat acquis d'un procès et à celle de l'aorist grec ; il recouvre à la fois l'un et l'autre, sans avoir la valeur propre de chacun des deux : son rôle est d'indiquer le procès accompli. (Meillet and Vendryes 1924, p. 248)

In (3) the absolute construction referring to advanced age indicates that the perfect mortua est denotes the process of dying and not the fact of being dead.

\begin{tabular}{cccc} 
Prouecta & aetate & mortua & est \\
move.forward.PTCP.F.SG.ABL & age.ABL & die.PTCP.F.SG & be.PRS.3SG \\
'Being aged, she died' (Cicero, Tusculanarum disputationum libri quinque) & \\
\hline
\end{tabular}

The same type of construction appears in Early Modern Spanish. In (4) the de-PP refers to the cause that operates in the process of dying ('to die from'). On the contrary, the por-PPs in the Mediaeval Spanish example (5) indicate the reasons for being dead ('to be dead because of').

\begin{tabular}{|c|c|c|c|c|c|c|c|c|}
\hline \multirow[t]{2}{*}{ (4) } & $\begin{array}{l}\text { Ella } \\
\text { She }\end{array}$ & $b$ & $\begin{array}{l}\text { es } \\
\text { RS.3S }\end{array}$ & $\begin{array}{c}\text { Muerta } \\
\text { die.PTCP.F.SG }\end{array}$ & $\begin{array}{c}\text { de } \\
\text { from }\end{array}$ & $\begin{array}{cc}\text { un } & \text { mal } \\
\mathrm{A} & \text { illness }\end{array}$ & $\begin{array}{l}\text { que } \\
\text { that }\end{array}$ & $\begin{array}{c}\text { tenía } \\
\text { have.PST.IPFV.3SG }\end{array}$ \\
\hline & \multicolumn{8}{|c|}{ 'She has died from an illness that she had' (CORDE, López de Tortajada 1646) } \\
\hline \multirow[t]{5}{*}{ (5) } & $L a$ & Bestia & no & es & muerta & por culpa & De & ningun \\
\hline & The & Beast & not & be.PRS.3s & die.PTCP.F.SG & because & of & no \\
\hline & \multicolumn{2}{|c|}{ omne } & mas & por & enfermedat & que & le & abino \\
\hline & \multicolumn{2}{|c|}{ man } & but & by & illness & that & him & come.to..PST.PFV.3SG \\
\hline & \multicolumn{8}{|c|}{$\begin{array}{l}\text { 'The beast is not dead because of a man but because of an illness that came to him' } \\
\text { (CORDE, Fuero de Teruel, c. 1300) }\end{array}$} \\
\hline
\end{tabular}

These examples may illustrate Mackenzie (2006) approach, worked out and proven through a large corpora analysis by Rosemeyer (2014). Mackenzie (2006, pp. 131-39) put forward the hypothesis

6 See Ramos Guerreira (2009) for a current overview of the functions of the Latin Perfect. The basic assumptions of Meillet and Vendryes (1924) are still valid.

7 Rosemeyer (2014) argues convincingly that early Modern Spanish begins around 1425 . Hence, the objection of an anonymous reviewer that example (4) may have been copied from an older version stemming from the 16 th century does not affect the argumentation. 
that, firstly, the perfect of Latin deponent verbs underwent "syntactic reanalysis"8 (ibid., p. 133) and that secondly, a "cyclical pattern of development" (ibid., p. 139) occurred that converted the copula + verbal adjective ${ }^{9}$ (again) into a perfect (see Table 2).

He justified his claim by arguing that in the Proto-Romance period, synthetic perfect forms were created (sequi, mori, nasci, etc.) even for those verbs which "exhibit a deponent-style E-perfect"10 (ibid., p. 133). ${ }^{11}$ This process led to a "generalization of the synthetic perfect" on the one hand and, on the other hand, a "reorganization of the membership of the class of intransitives that entered into the periphrastic construction" (ibid., pp. 133-34). Latin deponent verbs with an activity aktionsart, such as fabulari ('to speak'), were ruled out, and presumably prototypical unaccusatives such as venire ('to come') $)^{12}$ were included (ibid., p. 134). According to Mackenzie (2006), the maintenance of the periphrastic construction with a semantically more homogeneous group is due to a functional split. The synthetic perfect functions as an anterior while the periphrastic construction is reanalyzed as a copula + verbal adjective construction with a "resultant-state" type of meaning. Mackenzie (ibid., pp. 134-35) conceded that there are examples of BE + past participle from Mediaeval Romance languages that suggest an anterior reading. However, most occurrences should be analyzed as resultative constructions. According to Mackenzie (ibid., p. 136), the resultative reading is supported by the distribution of perfect and imperfect forms with an aspectual, rather than anterior, meaning due to the temporal context. Finally, the copular analysis explains the "otherwise surprising omission of the reflexive pronoun" (ibid., p. 137) in constructions such as es levantado that reads rather 'is on his feet' and not 'has got up'.

Some additional criteria should be taken into consideration. In their analysis of the decline of the BE-perfect construction in Canadian French, Sankoff and Thibault (1977, pp. 85-94) proposed a number of criteria to distinguish $\mathrm{BE}+$ past participle as an anterior and as a copula construction. Adverbials referring to the manner in which an event is realized are evidence against the copula + adjective interpretation. Adverbials expressing the motivation of a subject referent for an action favor an eventive interpretation. Finally, if the construction does not denote a resultant state that persists at reference time, it has to be interpreted as an anterior.

Mackenzie (2006) only illustrated his findings with a couple of examples. Hence, his claim that the "vast majority of the examples in the mediaeval corpus" exhibit a resultant-state type of meaning remains intuitive. Rosemeyer (2014) has applied the mentioned criteria systematically to vast corpora of Spanish data of the mediaeval and early modern period. Following Detges (2001), he asserts that there is a metonymic link between anteriors and resultatives (ibid., p. 49): a resultant state has been brought about by a previous event and a previous event may lead to a resultant state that persists at reference time. Therefore, the interpretation is ambiguous in the absence of any of the markers discussed in Sankoff and Thibault (1977) and Mackenzie (2006). Nonetheless, meticulous interpretation and statistical analysis led Rosemeyer $(2014$, p. 37) to the claim that, "in its prototypical use, Old Spanish ser + PtcP does not express anteriority."

8 We will understand 'reanalysis' as "a mechanism which changes the underlying structure of a syntactic pattern and which does not involve any immediate or intrinsic modification of its surface manifestation" (Harris and Campbell 1995, p. 61, the definition goes back to (Langacker 1977)).

9 We find the idea of a surprising development from a preterite function to a copular + verbal adjective construction as early as in Herzog (1910, pp. 135-41).

10 By "E-Perfect" Mackenzie (2006) refers to a BE + past participle construction. See also Legendre and Sorace (2003) use illustrated in Table 1.

11 The formulation is misleading. Mackenzie focusses on the form, not on the function. He refers to the existence of an ESSE + participle construction of these verbs in Mediaeval Romance that formally seem to continue the deponent-style analytic perfect without having this function (any more).

12 In line with Sorace (2000), Mackenzie (2006) considers change of location verbs as well as change of state verbs prototypical unaccusatives. 
Table 1. Auxiliary selection in French and Italian (adapted from Legendre and Sorace 2003, p. 227).

\begin{tabular}{|c|c|c|}
\hline Auxiliary & Selected & Verb Classes \\
\hline French & Italian & \\
\hline \multirow[t]{2}{*}{$\mathrm{E}^{13}$} & $\mathrm{E}$ & Change of location: arrivare/arriver, venire/venire and so forth. \\
\hline & & Change of state \\
\hline $\mathrm{E}$ & $\mathrm{E}$ & a. Change of condition: morire/mourir, etc. \\
\hline \multirow[t]{2}{*}{$E^{*}$} & $\mathrm{E}$ & b. Appearance: apparire/apparaître, etc. \\
\hline & & c. Indefinite change in a particular direction: \\
\hline$E^{*}$ & $\mathrm{E}$ & salire/monter, scendere/descendre \\
\hline A & $\mathrm{E}^{*}$ & appassire/faner, peggiorare/empirer, etc. \\
\hline A & $\mathrm{E}^{*}$ & Continuation of pre-existing state: durare/durer, etc. \\
\hline & & Existence of state: \\
\hline A & $\mathrm{E}$ & a. essere/être \\
\hline $\mathrm{A}$ & $E^{*}$ & b. esistere/exister, bastare/suffire à \\
\hline & & Uncontrolled processes \\
\hline A & $\mathrm{A}^{*}$ & a. Emission: risuonare/résonner, etc. \\
\hline A & A & b. Bodily functions: sudare/suer, etc. \\
\hline A & $\mathrm{A}^{*}$ & c. Involuntary actions: tremare, trembler, etc. \\
\hline A & $\mathrm{A}^{*}$ & Motional controlled processes: nuotare/nager, etc. \\
\hline $\mathrm{A}$ & $\mathrm{A}$ & Non-motional controlled processes: lavorare/travailler, etc. \\
\hline
\end{tabular}

Table 2. Development of ESSE + past participle from Latin to Romance (Mackenzie 2006, p. 139).

\begin{tabular}{ll}
\hline Phase 1 & Latin mortuus est (perfect) \\
\hline Phase 2 & Early Romance morz est, muetro es and so on (copula-adjective) \\
\hline Phase 3 & Modern Romance est mort, ha muerto and so on (perfect) \\
\hline
\end{tabular}

In addition, Rosemeyer proved that in Early Modern Spanish, the opposition between SER + past participle and HABER + past participle "was reanalyzed as an opposition between two auxiliaries for one and the same construction, the anterior" (ibid., p. 255). Due to the metonymic relation of anteriors and resultatives, the SER + past participle-construction underwent a functional change, probably supported by the spread of HABER + past participle to less prototypical verb classes in terms of Sorace (2000) Auxiliary Selection Hierarchy (see Table 1). The growing restriction of SER-selection to high frequency verbs of change of location (entrenchment) led to the formulation of a new rule: when confronted with the choice between SER + past participle and HABER + past participle, use SER + past participle if you wish to express a past change of location event (ibid., p. 234). In Kailuweit (2015), I claimed that an analogous process took place in French between the 17th and 19th century, leading to considerable loss of the ÊTRE + past participle construction with verbs of change of state and a fossilization of the ÊTRE + past participle construction with verbs of change of location. As in Early Modern Spanish, the remaining cases of $\mathrm{BE}+$ past participle are not restricted to resultative readings. ${ }^{14}$

In light of the theoretical questions discussed in this volume, the details of this second reanalysis may not be as pertinent as those of the first. While the second reanalysis follows the grammaticalization path for perfects observed in an extensive number of languages, the fact that the opposite process seems to have taken place from Latin to Romance is puzzling.

13 E refers to a BE + past participle construction, A to a HAVE + past participle construction.

14 It is interesting to note that Cennamo (2008, p. 132) suggests on the basis of Old Neapolitan data that change of location is rather a peripheral than a core category of unaccusativity. On the one hand, this confirms the findings of Mateu (2009) and Rosemeyer (2014) for Old Spanish, on the other hand in seems to indicate that in Old Neapolitan the reorganization of BE-selection we find in Early Modern Spanish and 17th to 19th Century French did not take place. 


\section{Discontinuity}

Being aware of the striking contradiction to established grammaticalization theories, Jacob (1994) denied any continuity from Latin deponent perfects to the Old Spanish SER + past participle construction. He pointed out that the resultative construction does not need any historical motivation since it consists of the combination of the copula BE and an adjectivized past participle (ibid., p. 363). ${ }^{15}$ However, it remains unclear why the association of the copular BE + past participle construction with the formally identical perfect construction of deponent verbs was lost.

In line with Jacob (1994), Cennamo (2008, p. 125) rejected the hypothesis of a formal and functional continuity between analytic perfects of Latin deponents and Romance BE + past participle constructions. Nonetheless, as Cennamo (ibid.) pointed out, the discontinuity is not an effect of the loss of deponents, as one might suggest, but, on the contrary, it is due to generalization of deponent perfect structure in Late Latin. ${ }^{16}$ According to Cennamo (ibid., p. 121), a central change took place in the transition from Latin to Romance as far as the encoding of transitivity, grammatical voice and relation was concerned. The data that Cennamo (2008) compiled show puzzling equivalences and interchangeability among voice forms. Hence, the active may be used in passive function and the passive may occur in active function. Therefore, the passive no longer consistently marked the undergoer ${ }^{17}$ argument and the active no longer marked the actor argument in subject function. A form, such as amatus sum in (6), could have four different interpretations out of context:

(6)

amatus sum
a. 'I was loved/I have been loved' (passive)
b. 'I loved/have loved' (active) (= amavi, active perfect)
c. 'I am beloved' (amatus = adjective; predicative construction)
d. 'I am (being) loved' (= amor)
(cf. Cennamo 2008, p. 121)

Hence, Jacob (1994, p. 363) hypothesis of an always-accessible copular interpretation of be falls short of a satisfactory description. As the data in Cennamo (2008) show, in contexts where BE + past participle continues to be associated with perfective readings, a copular analysis is excluded.

An additional problem came up with the loss of the case system. As long as case-marking the nominative could be distinguished from the accusative, speakers could easily identify the semantic roles of verbal arguments. Hence, the loss of the voice system illustrated in (6) did not substantially impair communication. Nonetheless, case-marking started to operate on an active-inactive basis (Cennamo 2008, p. 122). The accusative appeared in subject function, to mark the undergoer argument of intransitives, such as anticausatives and other verbs denoting change of state or location, passives and impersonals. Accusatives could be found inclusively with non-agentive activities and even mark the actor of transitive verbs, although the nominative form continued to be the canonical case for subjects. Hence, case-marking no longer helped to consistently identify the semantic roles of verbal arguments. A construction showing the prior form of the passive voice such as puellam amata $(m)$ est (7) out of context could be ambiguous between an active interpretation with puellam marking the actor (7a) or, with two arguments, the undergoer $(7 \mathrm{~b})$. It could also have a passive interpretation, with puellam marking the undergoer $(7 \mathrm{c}-\mathrm{d})$ :

15 We find this construction in Classical Latin as well as in Modern French, Italian, English or German. Modern Spanish, however, uses estar (<STARE) as a copula. See Pountain (2000) for an account of the process that led to the functional extension of ESTAR + past participle substituting SER + past participle as a resultative construction.

16 Flobert (1975, pp. 410-19) calls this process deponentization.

17 I refer to RRG macroroles (actor and undergoer) to indicate semantic functions (see Van Valin 2005). Cennamo (2008) uses the formalism common in typological studies $(\mathrm{O} / \mathrm{SO}$ and $\mathrm{A})$ in an equivalent way. 
puellam amata $(m)$ est
a. 'The girl has loved' (puellam = A)
b. 'She has loved the girl' (puellam = U)
c. 'The girl was / has been loved' (puellam = U)
d. 'The girl is (being) loved' (puellam = U)
(cf. Cennamo 2008, p. 123)

The interaction of the two phenomena (the loss of the voice opposition and case-marking indicating syntactic and semantic status), illustrated by puellam in (7), leads to significant changes taking place in the encoding of the argument structure of the clause in the transition from Latin to Romance: the generalization of the synthetic perfect, the grammaticalization of HABERE + past participle marking the Actor function of the subject with transitive and, in the long run, also intransitive constructions and, last but not least, the reanalysis of BE + past participle marking the undergoer argument of a resultative construction with intransitive verbs, especially those denoting change of state (Mackenzie 2006; Cennamo 2008; Rosemeyer 2014).

Note that the findings contradict not only the continuity of a perfect use of ESSE + past participle to SER + past participle but also the continuity of a copula function of esse in combination with the verbal adjective that formally continues the past participle. The well documented cases of active readings of forms of the amatus sum type (Cennamo 1997, 2001, 2008) ${ }^{18}$ seem to indicate that values attributed to ESSE + past participle in Classical Latin have become defunctionalized. ${ }^{19}$ Table 3 resumes the findings of the last two sections of this chapter:

Table 3. Development of SER + past participle < ESSE + past participle.

\begin{tabular}{cccc}
\hline Classical Latin & Late Latin & Mediaeval Spanish & Early Modern Spanish \\
\hline ESSE + PtcP & ESSE + PtcP & SER + PtcP & SER + PtcP \\
\hline (U-marking) & & U-Marking & U-Marking \\
(Resultative) & Defunctionalization? & $\begin{array}{c}\text { Resultative } \\
\text { (Anterior) }\end{array}$ & Anterior \\
Anterior & & & \\
Aorist & & & \\
\hline
\end{tabular}

\section{Exaptation, Refunctionalization, Decapitalization}

As we have seen, the development of Latin ESSE + past participle to Mediaeval Spanish SER + past participle contradicts the common assumption of a grammaticalization path from resultative constructions to aorist constructions. Actually, the development seems to be more or less the other way round. While the analytic perfect of Latin deponent verbs had an aorist and an anterior reading and appear to be only marginally ambiguous allowing a resultative reading, Mediaeval Spanish SER + past participle constructions are clearly not aoristic and have to be interpreted in most cases as resultative constructions. An anterior reading only marginally comes into play. However, this development does not seem to be a motivated reversal of the grammaticalization process but rather a reset after a period of defunctionalization.

In the following, I will briefly discuss three concepts brought up in the last years in the context of questioning the irreversibility und unidirectionality of grammaticalization paths: exaptation, refunctionalization and capitalization. My objective will be to show that the development of $\mathrm{BE}+$ past

18 An anonymous reviewer criticised that my argumentation depends too much on the works of Cennamo and the references she adduces. However, as Latinists confirmed to me, her references are valid and even more current studies of Latin Grammar, such as Baños Baños (2009), do not contradict her findings. Since my claim in this paper is primarily a theoretical one, this is not the place to add wider bibliographic and empirical support to confirm her findings. See Drinka (2017, pp. 139-40) for a recent affirmative summary of Cennamo (2008).

19 I use the term 'defunctionalization' in line with Smith (2011, p. 269) as "the loss of value or function of an opposition." 
participle from Latin to Spanish, sketched out in the last two sections of this chapter, is not an idiosyncratic case but a specific type of counter-example to grammaticalization theory that could be described with the help of the aforementioned concepts. I shall, however, invert the concept of capitalization introduced by Pountain (2000) and discuss a process that I call 'decapitalization'.

The concept of 'exaptation' was introduced by Lass $(1990,1997)$ as a limited alternative to grammaticalization in specific functional domains. Exaptation makes use of the general concept of reanalysis that I have already used in the contribution and will not discuss on its own. ${ }^{20}$ In Lass' terms, exaptation, adapted from biology where it "denote[s] the co-optation during evolution of structures originally developed for other purposes" 21 is "a kind of conceptual renovation, as it were, of material that is already there but either serving some other purpose, or serving no purpose" (Lass 1997, p. 316). As Narrog (2007) shows, Lass' examples for linguistic exaptation, the re-use of Indo-European ablaut inter alia, are not always convincing and even if they are, they could be easily considered isolated counter examples to the unidirectionality of grammaticalization. However, Narrog (2007) himself proves that causativization at several stages of Japanese as well as in a couple of unrelated languages occur in a systematic way that contradicts the claim of grammaticalization theory and could be better described in terms of exaptation.

In his 1990 paper, Lass highlighted the possibility that languages recycle morphological material that does not serve to code a functional distinction anymore and therefore could be considered 'junk'. According to Cennamo (2008) findings, this seems to be precisely the case for ESSE + past participle in Late Latin. Apparently, both functional values coded by this construction in Classical Latin were jettisoned; the passive function (amatus sum opposed to amavi) as well as the perfect function (amatus sum opposed to amor). But instead of being dropped, the form persisted and was recycled as a present tense passive marker for transitive $\mathrm{e}^{22}$ and a resultative marker for intransitive verbs.

Nonetheless, the concept of morphological junk has been criticized in the literature. ${ }^{23}$ As Narrog (2007, p. 7) pointed out: "it is rarely the case that linguistic structure is completely functionless or useless." Lass himself conceded in 1997, that "the most common kinds of exaptation [ . . ] are not based on co-optation of junk. 'Useful' [ . . ] features can be adapted too" (Lass 1997, p. 318).

In this line of thinking, we could account for the fact that the construction ESSE + past participle - even if it allows for an active transitive reading at some point in history-is not completely functionless. The conjugated form of esse still codes the categories of person and number. ${ }^{24}$ Presumably, speakers recognized these categories easier in the case of esse as an irregular verb than in the case of regular conjugated full verbs affected by phonetical abrasion on their endings.

In a more recent paper, Smith (2011) took up the discussion on exaptation on the bases of Lass (1997). He pointed out that there is a conceptually significant distinction between cases of exaptation including loss of the original function and others with a new function grafted onto the original one (Smith 2011, p. 305). Following Smith, the first case should be labelled refunctionalization, the second adfunctionalization. Since the main function of ESSE + past participle in Classical Latin, the perfect function including an aorist reading, is lost leading to defunctionalization, the recycled use of the forms in a resultative construction could be described as an instance of refunctionalization in Smith's terms.

However, according to Smith (2011), refunctionalization as the acquisition of a new value or function by a morphological opposition, does not recycle morphological 'junk' but equals a process

20 I will follow Narrog $(2007$, p. 3) who considers reanalysis a more powerful mechanism that include grammaticalization and other systematic processes of grammatical change.

21 A typical example are feathers, originally thermoregulatory devices of warm-blooded proto-birds, that only later were capitalised for flight (Lass 1990, p. 80).

22 Of course, passive constructions of transitive verbs could have a resultative meaning, too.

23 See references in Narrog (2007).

24 However, some forms were substituted by forms of sedere. 
that has been described in the history of art and architecture as "skeuomorphy" (ibid., pp. 275-76). A 'skeuomorph' is a "feature which starts off as functional, loses its functionality and becomes decorative-that is, in some sense, cultural (ibid., p. 277)." They still have content, that is, they are more in tune to people's expectations, so objects or buildings designed with skeuomorphs would be more aesthetically pleasing that those without skeuomorphs. Applied to the case of refunctionalization, skeuomorphy explains a vestigial continuity between the old and the new function:

Whilst the original functional distinctions disappear, the formal oppositions that used to express them seem to retain a vestige of abstract content-they become, in the terminology introduced earlier, skeuomorphy, not junk —and, where one of the items is discarded or the opposition assumes a new function, it is this vestigial content that seems to determine what developments take place. (Smith 2011, p. 314)

If we follow Smith's argumentation, our description of the development of ESSE + past participle in Late Latin has to be revisited. It is not an instance of total defunctionalization. It seems to be that the marginal resultative function of the Classical Latin ESSE + past participle construction is maintained as a vestige. I suppose that it is in line with the findings of Cennamo (2008) to say that 'resultativity' attains the more abstract value of affect or concern. After the loss of the perfect and the passive value of the structure, this abstract vestigial content explains its refunctionalization in a new organized system of argument marking, where ESSE + past perfect highlights the undergoer function of the argument in contexts of change of state and change of location.

Let me conclude this section by bringing one last concept into play: capitalization introduced by Pountain (2000) in order to describe processes of weak grammaticalization without phonetical reduction:

Use of the term 'capitalization' is an attempt to label the historical process by which a linguistic feature which already exists in a language comes to be substantially exploited for wider purposes, sometimes simply making overt distinctions which were previously covert but sometimes apparently creating new expressive possibilities. (Pountain 2000, p. 295)

I would like to raise the question of whether Pountain's considerations could be useful for describing a somehow inverted process that, consequently, has to be labeled 'decapitalization'. If we substitute 'wider purposes' with 'tighter purposes', the first part of Pountain's definition seems to fit well to our case. While in Classical Latin, ESSE + past perfect had a (dominant) perfect and aorist value and appeared only marginally as a resultative, in Mediaeval Spanish, SER + past participle is mainly a resultative construction. Hence, it has been decapitalized. The process of decapitalization turns overt distinctions into covert ones. The overt perfect value of ESSE + past participle in Classical Latin was (almost) covert in Mediaeval Spanish and appeared only marginally in the data. The apparently new expressive possibility of marking an undergoer argument became central. However, mutatis mutandis, the function of marking an undergoer continued the semantic properties not only of passives but also of deponent verbs, although in a more systematic way.

What would be the added value of a concept labeled 'decapitalization' in the theoretical field discussed in this volume? While 'capitalization' seems to operate in the same direction as grammaticalization, 'decapitalization' works counter-directional to grammaticalization. As we have seen, the fairly well-established concept of exaptation refers to a wide range of counter-directional processes. According to Smith (2011), at least two forms of exaptation have to be distinguished: refunctionalization and adfunctionalization. As far as refunctionalization in Smith's terms is concerned, the defining criterion is 'skeuomorphy', a highly technical concept of art history that, in my opinion, is not completely convincing in the field of linguistics. In art history, skeuomorphy refers to elements that are maintained as decorative elements, although having lost their original functions. Smith (2011, p. 277) himself conceded that 'decorative,' "is not a term usually associated with serious 
studies of language." 25 However, it seems to be more problematic to substitute, as Smith does, 'decorative values' in art history with 'a vestige of abstract content' in linguistics.

My claim is that we could better deal with this type of linguistic change if we consider the vestigial abstract value as a remnant of a process of decapitalization. Let me discuss this concept briefly. My considerations are, of course, inspired by Pountain's concept of capitalization. However, it seems to be fruitful to have a look at the use of 'decapitalization' in economics and social science. According to Padley (1986, p. 183), 'decapitalization' means "the loss of capital for accumulation" or as Van Brabant (1987, p. 388) puts it: "the stock of capital shrinks over time." In my opinion, it would be more enlightening to use this concept metaphorically in historical linguistics than the opaque term 'skeuomorphy', especially in cases of a decrease in structural distinctions. Other grammatical changes from Latin to Romance might be described as decapitalization, too; for example, the loss of the case system. The morphemes $-a(m),-u(m)$ and $-a s$, -os decapitalized their functional load. While denoting case, number and gender in Latin, they only refer to number and gender in Romance languages. But, of course, this is only speculative suggestion, which has to be discussed more in detail in an additional study.

\section{Conclusions}

In this chapter, I based my argument on the studies of Cennamo $(1997,2001,2008)$ and Rosemeyer (2014), in order to show that the development of BE + past participle from Classical Latin to Mediaeval and Early Modern Spanish neither exhibits functional continuity nor equals the development of HAVE + past participle. While HAVE + past participle embarks upon a grammaticalization path that is held universally, $\mathrm{BE}+$ past participle seems to take the opposite path at the first stage, regressing from an aoristic construction in Classical Latin to a resultative construction in Mediaeval Spanish. Since this development contradicts with common insights on grammaticalization, the continuity of the construction from Latin to Spanish has been denied. Exaptation theory (Lass 1990,1997) seems to be a theoretical framework that deals with processes of linguistic change that exhibit only continuity on the formal side, while on the functional side, it comes to total defunctionalization. The morphemes left-in our case the BE + past participle structure-appear to be morphological 'junk' that might be recycled in order to adopt new functions. However, functional discontinuity does not seem to be complete in many cases. As Smith (2008) pointed out, it is more probable that when functional opposition is jettisoned, a vestigial abstract content remains on the marked element. In our case, it is the resultative value, marginal for Classical Latin ESSE + past participle that is maintained, presumably as a more abstract feature of affect or concern. This abstract feature determined refunctionalization by paving the way to a new functional load for SER + past participle in Mediaeval Spanish: the marking of an undergoer subject. The fact that the perfect and aorist functions of ESSE + past participle are jettisoned while the marginal resultative value becomes central in Mediaeval Spanish, as well as in other Mediaeval Romance varieties, should be described as decapitalization. The concept of 'decapitalization,' with its connotations stemming from economics and social science, denotes that in a given situation of linguistic change, a feature could be exploited for tighter purposes. In the development from Latin to Proto-Romance, this seems to happen not only to ESSE + past participle but also to the nominal endings expressing gender, number and case. Further research will have to clarify to what extent the concept of 'decapitalization' is useful for describing processes of functional reduction in language change, not only in the special case of the development of Proto-Romance, but also for a wider set of unrelated languages.

Funding: This research received no external funding.

Conflicts of Interest: The author declares no conflict of interest.

25 In my opinion, this is not the core of the problem. Aesthetic aspects should not be neglected in language history. 


\section{References}

Alexiadou, Artemis, Elena Anagnostopoulou, and Martin Everaert, eds. 2004. The Unaccusativity Puzzle. Oxford: Oxford University Press.

Aranovich, Raúl, ed. 2007. Split Auxiliary Systems. A Cross-Linguistic Perspective. Amsterdam: John Benjamins.

Aranovich, Raúl. 2003. The Semantics of Auxiliary Selection in Old Spanish. Studies in Language 27: 1-37. [CrossRef]

Baños Baños, Jose Miguel, ed. 2009. Sintaxis del latín clásico. Madrid: Liceus.

Batlle, Mar. 2002. L'expressió dels temps compostos en la veu mitjana il la passiva pronominal. Barcelona: Publicacions de l'Abadia de Montserrat.

Bentley, Delia, and Thor Eythórsson. 2004. Auxiliary selection and the semantics of unaccusativity. Lingua 114: 447-71. [CrossRef]

Benzing, Joseph. 1931. Zur Geschichte von ser als Hilfszeitwort im Spanischen. Zeitschrift für romanische Philologie 51: 385-460. [CrossRef]

Bybee, Joan L., Revere D. Perkins, and William Pagliuca. 1994. The Evolution of Grammar. Tense, Aspect and Modality in the Languages of the World. Chicago: University of Chicago Press.

Cardoso, Adriana, and Sandra Pereira. 2003. Contributos para o estudo da emergência do tempo composto em Português. Revista da Associação Brasileira de Linguística 2: 159-81.

Cennamo, Michela. 1997. The loss of the voice dimension between Late Latin and Early Romance. In Historical Linguistics 1997, Selected Papers from the 13th International Conference on Historical Linguistics. Edited by Monika S. Schmid, Jennifer R. Austin and Dieter Stein. Amsterdam: John Benjamins, pp. 77-100.

Cennamo, Michela. 2001. L'extended accusative e le nozioni di voce e relazione grammaticale nel latino tardo e medievale. In Ricerche linguistiche tra antico e modern. Edited by Valeria Viparelli. Naples: Liguori, pp. 3-27.

Cennamo, Michela. 2008. The rise and development of analytic perfects in Italo-Romance. In Grammatical Change and Linguistic Theory: the Rosendal Papers. Edited by Thor Eythórsson. Amsterdam and Philadelphia: Benjamins, pp. 115-42.

Detges, Ulrich. 2001. Tiempo, retórica y cambio funcional: La evolución del perfecto compuesto español desde la Edad Media hasta el siglo XX. In Grammatikalisierung in den iberoromanischen Sprachen. Edited by Barbara Schäfer-Pries, Hildegard Klöden and Rolf Kailuweit. Wilhelmsfeld: Egert, pp. 77-112.

Drinka, Bridget. 2017. Language Contact in Europe: The Perfect Tense through History. Cambridge: Cambridge University Press.

Elvira, Javier. 2001. Intransitividad escindida en español: El uso auxiliar de ser en español medieval = Estudios de Lingüística 15. San Vicente del Raspeig: Universidad de Alicante.

Flobert, Pierre. 1975. Les Verbes Déponents Latins des Origines à Charlemagne. Paris: Les Belles Lettres.

Guilherme, Ana Rita. 2009. Era Chegado ho tempo. Um contributo para o estudo da construção Ser + Particípio Passado em Português Antigo. Master's thesis, Universidade de Lisboa, Lisboa, Portugal.

Harris, Alice C., and Lyle Campbell. 1995. Historical Syntax in Cross-Linguistic Perspective. Cambridge: Cambridge University Press.

Harris, Martin. 1982. The 'past simple' and the 'present perfect' in Romance. In Studies in the Romance verb. Essays Offered to Joe Cremona on the Occasion of His 60th Birthday. Edited by Martin Harris and Nigel Vincent. London: Croom Helm, pp. 42-70.

Herzog, Eugen. 1910. Das to-Partizip im Altromanischen. Ein Beitrag zur Lehre vom syntaktischen Wandel. In Prinzipienfragen der romanischen Sprachwissenschaft. Festschrift f. W. Meyer-Lübke zum 50. Geburtstag. Halle: Niemeyer, pp. 76-186.

Jacob, Daniel. 1994. Die Auxiliarisierung von habere. Freiburg im Breisgau: Albert-Ludwigs-Universität Freiburg, Habilitationsschrift.

Kailuweit, Rolf, and Malte Rosemeyer, eds. 2015. Auxiliary Selection Revisited: Gradience and Gradualness. Berlin and New York: De Gruyter.

Kailuweit, Rolf. 2011. Le choix de l'auxiliaire: Être ou avoir en français standard contemporain. In Peregrinatio in Romania: Artículos en homenaje a Eugeen Roegiest con motivo de su 65 cumpleaño. Edited by Renata Enghels, Machteld Meulleman and Clara Vanderschueren. Gent: Academia Press, pp. 397-420.

Kailuweit, Rolf. 2015. BE or HAVE in Contemporary Standard French-Residua of Semantic Motivation. Edited by Rolf Kailuweit and Malte Rosemeyer. Berlin: Walter de Gruyter GmbH, pp. 249-75. 
Langacker, Ronald W. 1977. Syntactic reanalysis. In Mechanisms of Syntactic Change. Edited by Charles N. Li. Austin: University of Texas Press, pp. 57-139.

Lass, Roger. 1990. How to do things with junk: exaptation in language evolution. Journal of Linguistics 26: 79-102. [CrossRef]

Lass, Roger. 1997. Historical Linguistics and Language Change. Cambridge: Cambridge University Press.

Legendre, Géraldine, and Antonella Sorace. 2003. Auxiliaires et intransitivité en français et dans les langues romanes. In Les langues romanes. Problèmes de la phrase simple. Edited by Danièle Godard. Paris: Editions du CNRS, pp. 185-234.

Levin, Beth, and Malka Rappaport Hovav. 1995. Unaccusativity. At the Syntax-Lexical Semantics Interface. Cambridge: MIT Press.

Mackenzie, Ian E. 2006. Unaccusative Verbs in Romance Languages. Basingstoke: Palgrave Macmillan.

Mateu, Jaume. 2009. Gradience and auxiliary selection in Old Catalan and Old Spanish. In Historical Syntax and Linguistic Theory. Edited by Paola Crisma and Giuseppe Longobardi. Oxford: Oxford University Press, pp. 176-93.

Meillet, Antoine, and Joseph Vendryes. 1924. Traité de grammaire comparée des langues classiques. Paris: Éd. Champion. Narrog, Heiko. 2007. Exaptation, Grammaticalization and Reanalysis. California Linguistic Notes 32: 1-26.

Padley, Rajendra. 1986. Sociology of Underdevelopment: Theories and Critiques. New Dehli: Mittal Publications.

Perlmutter, David M. 1978. Impersonal passives and the Unaccusative Hypothesis. In Proceedings of the 4th Annual Meeting of the Berkeley Linguistics Society. Edited by Jeri J. Jaeger, Christine Chiarello, Henry Thompson and Farrell Ackerman. Berkeley: UC Berkeley, pp. 157-89.

Pountain, Christopher J. 2000. Capitalization. In Historical Linguistics 1995, Volume 1: General Issues and Non-Germanic Languages. Edited by John Charles Smith and Delia Bentley. Amsterdam: Benjamins, pp. 295-309.

Ramos Guerreira, Agustín. 2009. Tiempo y Aspect. In Sintaxis del latín clásico. Edited by Jose Miguel Baños Baños. Madrid: Liceus, pp. 157-89.

Rosemeyer, Malte. 2014. Auxiliary Selection in Spanish. Gradience, Gradualness and Conservation. Amsterdam and Philadelphia: Benjamins.

Rosemeyer, Malte. 2015. Entrenchment and Discourse Traditions in Spanish Auxiliary Selection. In Auxiliary Selection Revisited: Gradience and Gradualness. Edited by Rolf Kailuweit and Malte Rosemeyer. Berlin and New York: De Gruyter, pp. 301-31.

Sankoff, Gillian, and Pierrette Thibault. 1977. Sankoff, Gillian, and Pierrette Thibault. 1977. L'alternance entre les auxiliaires avoir et être en français parlé à Montréal. Langue française 34: 81-108. [CrossRef]

Schwenter, Scott A. 1994. The Grammaticalization of an anterior in Progress: Evidence from a Peninsular Spanish dialect. Studies in Language 18: 71-111. [CrossRef]

Smith, John C. 2008. The refunctionalisation of first-person plural inflection in Tiwi. In Morphology and Language History. In Honour of Harold Koch. Edited by Claire Bowern, Bethwyn Evans and Luisa Miceli. Amsterdam and Philadelphia: Benjamins, pp. 341-48.

Smith, John C. 2011. Change and continuity in form-function relationships. In A Cambridge History of the Romance Languages, Vol. 1: Structures. Edited by Martin Maiden, John Charles Smith and Adam Ledgeway. Cambridge: CUP, pp. 268-316.

Sorace, Antonella. 2000. Gradients in auxiliary selection with intransitive verbs. Language 76: 859-90. [CrossRef]

Squartini, Mario, and Pier Marco Bertinetto. 2000. The simple and compound past in Romance languages. In Tense and Aspect in the Languages of Europe. Edited by Östen Dahl. Berlin: Mouton de Gruyter, pp. 403-39.

Van Valin, Robert D., Jr. 2005. Exploring the Syntax-Semantics Interface. Cambridge: Cambridge University Press.

Van Brabant, Josef M. 1987. Adjustment, Structural Change and Economic Efficiency: Aspects of Monetary Cooperation in Eastern Europe. Cambridge: Cambridge University Press.

Vincent, Nigel. 1982. The Development of the Auxiliaries HABERE and ESSE in Romance. In Studies in the Romance Verb. Essays Offered to Joe Cremona on the Occasion of His 60th Birthday. Edited by Nigel Vincent and Marin Harris. London: Croom Helm, pp. 71-97.

Yllera, Alicia. 1980. Sintaxis histórica del verbo español: Las perífrasis medievales. Zaragoza: Universidad de Zaragoza.

(C) 2018 by the author. Licensee MDPI, Basel, Switzerland. This article is an open access article distributed under the terms and conditions of the Creative Commons Attribution (CC BY) license (http:/ / creativecommons.org/licenses/by/4.0/). 


\title{
Article \\ Refunctionalization. First-Person Plural of the Verb Haber in the History of Spanish
}

\author{
Axel Hernández Díaz \\ Facultad de Filosofía y Letras, Universidad Nacional Autónoma de México, Mexico City 04510, Mexico; \\ hernandez.axel@gmail.com
}

Received: 10 October 2018; Accepted: 24 January 2019; Published: 31 January 2019

\begin{abstract}
In this paper, the first-person plural diachronic behaviour of the verb form habemos with an existential value is analysed to explore its recovery in current Spanish as a case of refunctionalization. The latter is understood as timely cooptation of a form, which begins with any of the form's characteristics. It is known that the cooptation's origin might be directly, indirectly or not at all related to the previous or original use of the form. Results shown here are based on the analysis of constructions in which the first-person plural verb form of haber is used with a possessive meaning, as an auxiliary, and as existential between the 13th and 21st century. While grammaticalization theory pays attention to processes that culminate with grammatical enrichment of words or constructions, the verb form habemos with an existential meaning does not show that behaviour. It is explained as a case of refunctionalization or, at least, specialization.
\end{abstract}

Keywords: refunctionalization; specialization; reanalysis; first-person plural of haber; existential verb form habemos

\section{Introduction}

It is well known that the verb haber has played a main role in several changes throughout the history of the Spanish language. From Latin to Spanish, it gradually changed from being a possessive transitive verb (1), used with that same meaning in Old Spanish (2a), to being an auxiliary (2b) and an existential verb (2c), until it finally was reduced to an auxiliary level and a plain verb within the existence domain.

(1)

\begin{tabular}{|c|c|}
\hline $\begin{array}{l}\text { HOSTI } \\
\text { enemy-NOM SG }\end{array}$ & $\begin{array}{l}\text { HABET } \\
\text { have-PRS 3SG }\end{array}$ \\
\hline (Virgilio, Eneida, I & \\
\hline "The enemy has & \\
\hline
\end{tabular}

(2) a

$\begin{array}{lll}\begin{array}{l}\text { enviar } \\ \text { to send-INF }\end{array} & \text { vos } & \text { quiero } \\ \text { do } & \begin{array}{l}\text { you-ACUS2P } \\ \text { avemos }\end{array} & \begin{array}{l}\text { want-PRS1S } \\ \text { heredades }\end{array} \\ \text { where } & \text { inheritances } \\ \text { (Cid, v. 1271) } & \\ \text { "I want to send you to Castilla where we have inheritances." }\end{array}$

b.

$\begin{array}{llll}\begin{array}{l}\text { rogo-l } \\ \text { beg.PST3S-DAT3SG }\end{array} & \begin{array}{l}\text { que } \\ \text { that }\end{array} & \begin{array}{l}\text { non } \\ \text { not }\end{array} & \begin{array}{l}\text { dixiesse } \\ \text { tell-PST.SBJC3SG }\end{array} \\ \begin{array}{lll}\text { que lo } \\ \text { that }\end{array} & \begin{array}{l}\text { auie } \\ \text { it-ACS3SG }\end{array} & \begin{array}{l}\text { acabado } \\ \text { AUX-IPFV3SG }\end{array} & \text { finished-PTCP }\end{array}$

MUROS

walls-ACS PL 


\begin{tabular}{|c|c|c|}
\hline fasta que & los otros & $\begin{array}{l}\text { ouiessen } \\
\text { AIX_IPFY SBIC } 3 P\end{array}$ \\
\hline cerca d-acabadas & sus & obras \\
\hline near of-finished-PТСР & POSS-3PL & works \\
\hline
\end{tabular}

$(C G, 12 \mathrm{a})$

"S/he begged her/him not to tell that s/he had finished until the others were about to finish their works."

$\begin{array}{lllll}\begin{array}{l}\text { Nos } \\ \text { we }\end{array} & \begin{array}{l}\text { habemos } \\ \text { AUX-PRES1P }\end{array} & \begin{array}{l}\text { mandado } \\ \text { ordered-PTCP }\end{array} & \begin{array}{l}\text { a } \\ \text { to-DAT }\end{array} \\ \begin{array}{l}\text { nuestro } \\ \text { POSS-1P }\end{array} & \begin{array}{l}\text { amado } \\ \text { beloved }\end{array} & \begin{array}{l}\text { clerigo } \\ \text { priest }\end{array} & \begin{array}{l}\text { Michelet de } \\ \text { Michelet from }\end{array} & \begin{array}{l}\text { Mares } \\ \text { Mares }\end{array} \\ \begin{array}{l}\text { que } \\ \text { that }\end{array} & \begin{array}{l}\text { ficiesse } \\ \text { make-PST.SBJC3S }\end{array} & \begin{array}{l}\text { adobar } \\ \text { to tan-INF }\end{array} & \begin{array}{l}\text { los dichos } \\ \text { the mentioned }\end{array} & \begin{array}{l}\text { altares } \\ \text { altars }\end{array}\end{array}$

(Gastos de la catedral de Pamplona, 1400, Spain, CORDE, s.v. habemos mandado)

"We have ordered our beloved priest Michelet of Mares to prepare the aforementioned altars."

\begin{tabular}{|c|c|c|c|c|}
\hline Conosciendo & esto & $e$ & sabiendo & que \\
\hline Knowing & this & and & realizing & that \\
\hline habemos & de & ir & a aquella & vida \\
\hline AUX-PRES1P & PREP & to go-INF & to that & life \\
\hline perdurable & [...] tenemos & por & derecho & de \\
\hline everlasting & AUX-PRES1P & by & law & PREP \\
\hline lo & emendar & $a$ & Dios & \\
\hline it-ACU3S & amend-INF & to & God & \\
\hline
\end{tabular}

(Real Monasterio de Santo Domingo, 1291, Spain, CORDE, s.v. habemos de)

"By knowing this and realising that we must go to that everlasting life [ ... ] we consider (that) we must redeem ourselves before God."

\begin{tabular}{|c|c|c|c|c|}
\hline $\begin{array}{l}\text { ssi } \\
\text { if }\end{array}$ & $\begin{array}{l}\text { en } \\
\text { in }\end{array}$ & $\begin{array}{l}\text { la } \\
\text { the }\end{array}$ & $\begin{array}{l}\text { iglesia } \\
\text { church }\end{array}$ & $\begin{array}{l}\text { mayor } \\
\text { main }\end{array}$ \\
\hline $\begin{array}{l}\text { ouyesse } \\
\text { there be- IPFV.SBJC3S }\end{array}$ & $\begin{array}{l}\text { obispo } \\
\text { bishop }\end{array}$ & $\begin{array}{l}\text { et } \\
\text { and }\end{array}$ & $\begin{array}{l}\text { el cabillo } \\
\text { the chapter }\end{array}$ & \\
\hline $\begin{array}{l}\text { della } \\
\text { of.ART }\end{array}$ & $\begin{array}{l}\text { rogase } \\
\text { beg-IPFV.SBJC3S }\end{array}$ & $\begin{array}{l}a \\
\text { to }\end{array}$ & $\begin{array}{l}\text { otro } \\
\text { someone else }\end{array}$ & \\
\hline $\begin{array}{l}q u e \\
\text { that }\end{array}$ & $\begin{array}{l}\text { por } \\
\text { by }\end{array}$ & $\begin{array}{l}y \\
\text { there }\end{array}$ & $\begin{array}{l}\text { pasasse } \\
\text { go by-IPFV.SBJC3S }\end{array}$ & $\begin{array}{l}\text { que } \\
\text { that }\end{array}$ \\
\hline $\begin{array}{l}\text { lo } \\
\text { it-ACUS3S }\end{array}$ & $\begin{array}{l}\text { ffiziesse } \\
\text { do-IPFV.SBJC3S }\end{array}$ & & & \\
\hline
\end{tabular}

(Setenario, 161.24)

"If in the main church there weren't a bishop and if the council of the church begged someone else to go there, let him do it." 
The replacement process from haber to tener has merited detailed studies in which the change has been explained using grammaticalization theory (Garachana Camarero 1994, 1997; Hernández Díaz 1999, 2006a, 2006b), which has also been used to explain the extension and generalization of haber as the prototype of existential verbs (Hernández Díaz 2007). It is well known that the change of haber from a transitive to an existential verb has reduced its paradigm to the third-person singular, since the rest of the grammatical paradigm turned out to be unnecessary because it was opposed to the new impersonal meaning of haber. Once the paradigm was reduced, haber was classified in grammar books as a third person verb (Bello 1997, §781-84; Gili Gaya 1943, §62; Seco 1989, §8.2.2; Real Academia Española 1973, §3.5.7.c y d; RAE/ASALE Real Academia Española \& Asociación de Academias de la Lengua Española, §41.6a, b).

Notwithstanding the new morphologic characterization of the verb, agreement between the noun phrase, designating what I call 'existing entity' and the verb, has consistently been rejected by grammarians (Bello 1997, §781-784; Gili Gaya 1943, §62; Seco 1989, §8.2.2 footnote; Real Academia Española 1973, §3.5.7.c, d; RAE/ASALE Real Academia Española \& Asociación de Academias de la Lengua Española, §41.6b, c, d, e). This rejection proves that the noun phrase has been reanalysed as the syntactical subject, because, even though existential sentences using haber are not classified as intransitive structures, they are closer to that classification than to that of transitive structures in speakers' minds. As we can see in example (3), agreement is a limited phenomenon in terms of frequency but it is a persistent phenomenon diachronically speaking.

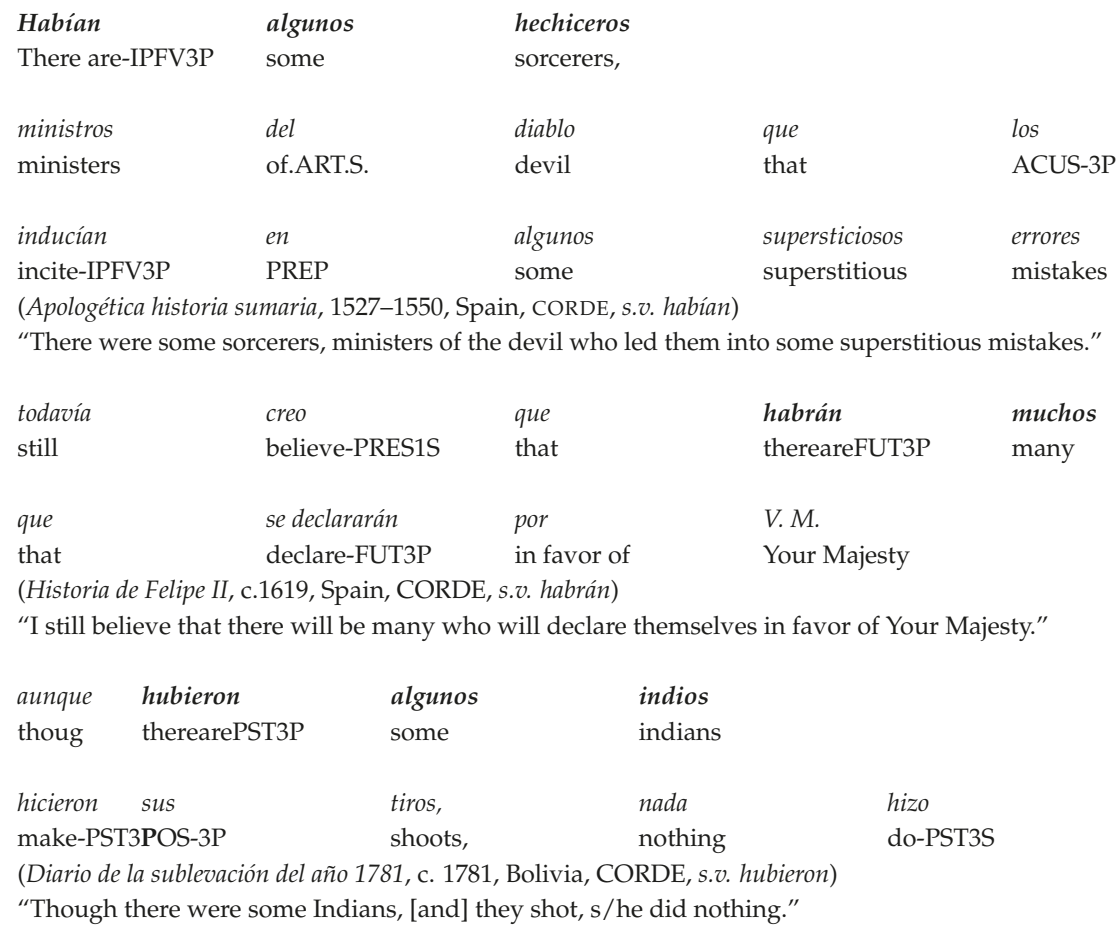

Apart from the agreement in example (3), there are cases in the first-person plural verb form of haber that use the presumably disappeared existential meaning of habemos. Some examples of these cases are displayed in (4), where reanalysis of the noun phrase as a subject is updated and there has been a refunctionalization, because the discussed verb form habemos experienced a change in function that goes beyond the syntactic description level. The phenomenon involves recovering an element 
from the brink of extinction in standard Spanish, which acquired a new semantic and pragmatic meaning, as I will show in this paper. ${ }^{1}$

(4) $\quad V$

$$
\text { esto }
$$

this

donde

Rionegro,

Rionegro

muchos blancos,

many whites indeed no

not

the es

be-PRES3S

\section{habemos}

there bePRES1P

cuatro costaos

four sides

(La marquesa de Yolombó, 1928, Colombia, CORDE, s.v. habemos muchos)

"Look: this is not Rionegro, where there are many of us whites indeed, entirely white."

\begin{tabular}{|c|c|c|c|c|}
\hline la organización & no & solicitó & los permisos & para \\
\hline the organisation & not & request-PST3S & the permissions & for \\
\hline $\begin{array}{l}\text { la venta de alcohol, } \\
\text { the sale of alcohol, }\end{array}$ & $\begin{array}{l}\text { por tanto } \\
\text { therefore }\end{array}$ & $\begin{array}{l}\text { hubimos } \\
\text { there be-PST1P }\end{array}$ & $\begin{array}{l}\text { varios } \\
\text { several }\end{array}$ & \\
\hline expositores & que & nos quedamos & con & el \\
\hline expositors & who & keep-PST1P & with & the \\
\hline
\end{tabular}

(Blog "Identidad y futuro," 2015, Chile)

"The organisation did not request the permissions for the sale of alcohol; therefore, there were many of us speakers who did not make the trip."

$\begin{array}{lllll}\text { ¿cómo } & \text { se } & \text { consigue } & \text { un experto? } & \text { Aqui en } \\ \text { How } & \text { IMPER } & \text { get-PRES3S } & \text { an expert } & \text { here in } \\ \text { nube docente } & \text { habremos } & \text { varios } & & \\ \text { cloud } & \text { teaching there } & \text { many } & \end{array}$

$\begin{array}{lll}\text { listos } & a & \text { apoyar-nos } \\ \text { ready } & \text { to } & \text { support.INF-ACUS1P }\end{array}$

(Webpage, 2015, México)

"How can someone get an expert? Here in the teaching cloud there will be many of us to support each other."

\section{Purpose}

The purpose of this paper is to analyse first-person plural diachronic behaviour of habemos, with an existential meaning, to show its resurgence in current Spanish language as a case of the refunctionalization and exaptation phenomena. I understand the latter as timely cooptation of a form, a process that begins with any of the form's characteristics, according to Lass (1990, p. 80). It is well

1 I know that the verb form habemos is used in some Spanish varieties. Castillo Lluch and Octavio de Toledo (2016) show that there exists documentation in recent oral corpuses from Spain and America where habemos is used not only as an existential but also as an auxiliary verb. However, its use and presence is marginal, especially as an auxiliary and it is considered as not typical in standard Spanish. Its presence as an existential has other syntactic and semantic implications. I believe that the different uses among varieties of Spanish show a different behavior; here, I am trying to show that its existential use entailed a different process from its grammaticalization as an auxiliary, which deserves an explanation based on refunctionalization and specialization-occurring recently-which are sociolinguistic nuances that deserve to be carefully studied. According to Bentivoglio and Sedano (1989), Blas Arroyo (2016), Castillo Lluch and Octavio de Toledo (2016), Claes $(2014,2016)$ Hernández Díaz $(2005,2006 b)$, Pato (2016) and Vaquero (1978), the concordance is related with sociolinguistic variation. Particularly, Claes (2014) suggests that the associations between the pluralization of haber and social groups vary more significantly depending on the respective speech communities. 
known that the cooptation's origin might be directly, indirectly or not at all related to the previous or original use of the form; in any case, it constitutes a conceptual innovation.

Exaptation changes, unlike any other changes, are characterized by renewing or recycling so called 'historic junk' in languages. Recycling starts with abandoned forms-at some linguistic analysis level-because they have lost their function (Lass 1990; Narrog 2007; Traugott 2004). Although it is true that morphological material rarely stops fulfilling its function, there are cases in which its function is partially lost or is kept only marginally. This, as we shall see in this paper, is the case for the verb form habemos in the history of the Spanish language.

\section{Corpus}

Results shown here are based on the analysis of 47,883 constructions in which the first-person plural of haber (habemos/avemos, hemos) is used with a possessive meaning, as an auxiliary and as an existential, in the period between the 13th and the 21st century (cf. Appendices A and B). However, as we know, possessive meaning was lost during the 16th century and, contrastingly, the verb form habemos is hardly registered as existential verb in writers preceding the 20th century. ${ }^{2}$ This difficulty is undoubtedly related to the generalized disapproval of haber concordance by normative grammar; it is also due to the textual typology represented in the linguistic corpus and the methodology used in the creation of the linguistic atlases (cf. Castillo Lluch and Octavio de Toledo 2016).

Cases were extracted from the Corpus Diacrónico del Español (CORDE) by the Real Academia Española (RAE). Additionally, cases corresponding to the 20th century were complemented with data from the Corpus de Referencia del Español Actual (CREA), also by the RAE. 21st century cases were gathered using Google and the webpage Socialmention.com (www.socialmention.com), which is used to perform real time searches in social networks and internet. The plurality in the corpus is caused by the difficulty faced in registering the habemos form/expression in standard Spanish, though the form/expression is highly productive in oral exchanges and in chats, which have a very similar format to that of a conversation and support it despite being in written form.

The data considered in this study are 6457 cases of habemos or avemos, as a possessive or as an auxiliary verb, 41,167 cases of hemos expressing the same meaning and 259 cases of the verb form habemos as an existential verb.

As I already have mentioned, not all of them correspond to an existential use of haber. For contrasting purposes, in order to prove what I have proposed, I also include possessive, auxiliary and what I have called 'prescriptive uses,' as well as 'other uses' that I will explain in detail later on. ${ }^{3}$ This study's scope is vast and heterogeneous in order to compare the diverse meanings of the verb form habemos from a diachronic perspective, for I believe that the wide variety of examples will play an important part in evidencing a contrast in quantitative terms. As we shall see, quantitative and qualitative differences in the meaning of the verb form habemos are crucial, for they help us understand why the existential use of this verb form is a case of refunctionalization and, in some way, a case of exaptation.

\section{Reanalysis, Refunctionalization and Subjectivization of the Verb Form Habemos}

As I have mentioned before, one of the changes experienced by haber was from being a transitive verb to an impersonal one. This change caused its paradigm to be reduced to the third-person

2 Some sporadic cases are recorded after the 16th century for different reasons: (1) because they are in fixed expressions (or idioms) as haber menester 'to be necessary', 'to need'; (2) because they are stylistic devices that writers use to reflect or to rebuild speech of another time; for example, several cases in the corpus are from Maladrón, a novel written by Miguel Ángel Asturias in the 20th century but set in 1600 .

3 The label 'other uses', as I will explain, groups prescriptive grammar recommendations of the verb form habemos. It is well known that different grammarians have discouraged the concordance in the habemos verbal form with existential meaning. The cases in which habemos is used to discourage the concordance have been brought together under this label. 
singular although, by participating in compound tenses and in verbal periphrases as an auxiliary verb, it managed to keep its whole paradigm identical to the one it used to have as a transitive verb.

Once habemos became an auxiliary verb, the first-person plural experienced a formal reduction. The change avemos cantado > hemos cantado (i.e., the phonetic reduction of the fourth person or the first-person plural of the perfect) has been carefully analysed in Bustos Gisbert and Bernal (1992) and, more recently, in Rodríguez Molina (2010, 2012). Rodríguez Molina (2012), based on Girón Alconchel (2004, p. 870), states that the alternation hemos/habemos (avemos) became less and less frequent once the transitive use of haber was lost. The shortened form was a more effective iconic manifestation of its use as an auxiliary. According to Rodríguez Molina, the reduction started at the beginning of the 16th century and by the 18th century habemos disappeared from the standard variant, although it has dialectal presence (cf. Rodríguez Molina 2012, p. 181) and the data on which this work is based are consistent with this. From the first quarter of the 16th century, the long forms are obsolete and appear mainly in legal texts, pastoral poetry and stigmatized dialects (Girón Alconchel 2004, p. 866).

The dialect variation is important in order to track the spread of change. Rodríguez Molina's data (Rodríguez Molina 2012, p. 207) suggest that the short form (hemos cantado) emerges in Aragon and spreads from there. According to this author, the causes of change can be grouped as: (1) phonetic reduction after the grammaticalization of compound verb tenses; (2) essentially phonetic factors (the bilabial occlusive voiced sound loss in the intervocalic position and the syncope of the low central vowel); (3) an analogy process to preserve the reduction in the verbal paradigm. ${ }^{4}$

According to our results, reduction must have happened around the 16 th century. The CORDE registers 98 cases of hemos used as an auxiliary verb in the 13th century, a number that increased in the following centuries and reached 4174 cases by the 16th century. Throughout this period, the frequency of habemos (avemos) and hemos as an auxiliary is similar but two centuries later, in the 18th century, the frequency of hemos is recorded at 2162 - and increases to 13,000 in the 19th century and 16,503 in the 20th century. On the other hand, the frequency of habemos decreases; there were 81 recorded cases in the 18th century, 68 cases in the 19th century and there was a small rebound in the 20th century, when there were 145 recorded cases. These results seem significant to us.

Based on the results of Table 1, we can state that habemos was kept in relation to the possessive meaning and, residually, as an auxiliary verb. On the other hand, hemos was generalized as the prototypical auxiliary verb (see the numbers in bold print in Table 1).

Table 1. Possessive meanings vs. habemos (avemos) and hemos as an auxiliary verb.

\begin{tabular}{ccccc}
\hline & \multicolumn{2}{c}{ Habemos/Avemos } & \multicolumn{2}{c}{ Hemos } \\
\cline { 2 - 5 } & Possessive & Auxiliary & Possessive & Auxiliary \\
\hline \multirow{2}{*}{ XIII } & $7 \%$ & $93 \%$ & $8 \%$ & $92 \%$ \\
& $(27 / 373)$ & $(346 / 373)$ & $(8 / 106)$ & $(98 / 106)$ \\
\hline \multirow{2}{*}{ XIV } & $10 \%$ & $90 \%$ & $6 \%$ & $94 \%$ \\
& $(13 / 124)$ & $(111 / 124)$ & $(12 / 197)$ & $(185 / 197)$ \\
\hline \multirow{2}{*}{ XV } & $21 \%$ & $79 \%$ & $1 \%$ & $99 \%$ \\
& $(106 / 496)$ & $(390 / 496)$ & $(2 / 459)$ & $(457 / 459)$ \\
\hline \multirow{2}{*}{ XVI } & $8 \%$ & $92 \%$ & $1 \%$ & $99 \%$ \\
& $(306 / 3715)$ & $(3409 / 3715)$ & $(29 / 4203)$ & $(4174 / 4203)$ \\
\hline \multirow{2}{*}{ XVII } & $10 \%$ & $90 \%$ & $2 \%$ & $98 \%$ \\
& $(135 / 1411)$ & $(1276 / 1411)$ & $(105 / 4512)$ & $(4407 / 4512)$ \\
\hline \multirow{2}{*}{ XVIII } & $2 \%$ & $98 \%$ & $7 \%$ & $93 \%$ \\
& $(2 / 83)$ & $(81 / 83)$ & $(13 / 2175)$ & $(\mathbf{2 1 6 2} / 2175)$ \\
\hline \multirow{2}{*}{ XIX } & $28 \%$ & $72 \%$ & $<0.5 \%$ & $99 \%$ \\
& $(29 / 97)$ & $(68 / 97)$ & $(7 / 13,007)$ & $(\mathbf{1 3 , 0 0 0 / 1 3 , 0 0 7 )}$ \\
\hline \multirow{2}{*}{ XX } & $8 \%$ & $92 \%$ & $<0.5 \%$ & $99 \%$ \\
& $(13 / 158)$ & $(145 / 158)$ & $(5 / 16,508)$ & $(\mathbf{1 6 , 5 0 3 / 1 6 , 5 0 8 )}$ \\
\hline
\end{tabular}

4 The reduction was habemos (avemos) $>$ hemos and also habedes (avedes) $>$ habéis. 
Table 1 shows very different use frequencies for habemos (avemos) vs. hemos as auxiliary verb forms in the 18th, 19th and 20th century. If one compares only the auxiliary meaning of these forms, as in Table 2, it appears that habemos (avemos) is marginally used as an auxiliary verb as compared to hemos.

Table 2. Habemos vs. hemos as auxiliary verbs.

\begin{tabular}{ccc}
\hline & $\begin{array}{c}\text { Habemos } \\
\text { Auxiliary }\end{array}$ & $\begin{array}{c}\text { Hemos } \\
\text { Auxiliary }\end{array}$ \\
\hline XVIII & $4 \%(81 / 2243)$ & $96 \%(2162 / 2243)$ \\
XIX & $<1 \%(68 / 13,068)$ & $99 \%(13,000 / 13,068)$ \\
XX & $<1 \%(145 / 16,648)$ & $99 \%(16,503 / 16,648)$ \\
\hline
\end{tabular}

Considering these results, it appears that habemos is also bound to disappear as an auxiliary verb form, especially during the 19th and 20th century, even if one considers its presence in some Spanish dialects. As a possessive verb, its situation is similar; during the 20th century it was used sporadically in fixed phrases like the ones in example (5a). It is clear that its use as an auxiliary or as a possessive verb form has no major relevance in terms of frequency. Habemos was registered in cases like the ones in example (5b), which, although recent, seem to be marginal.

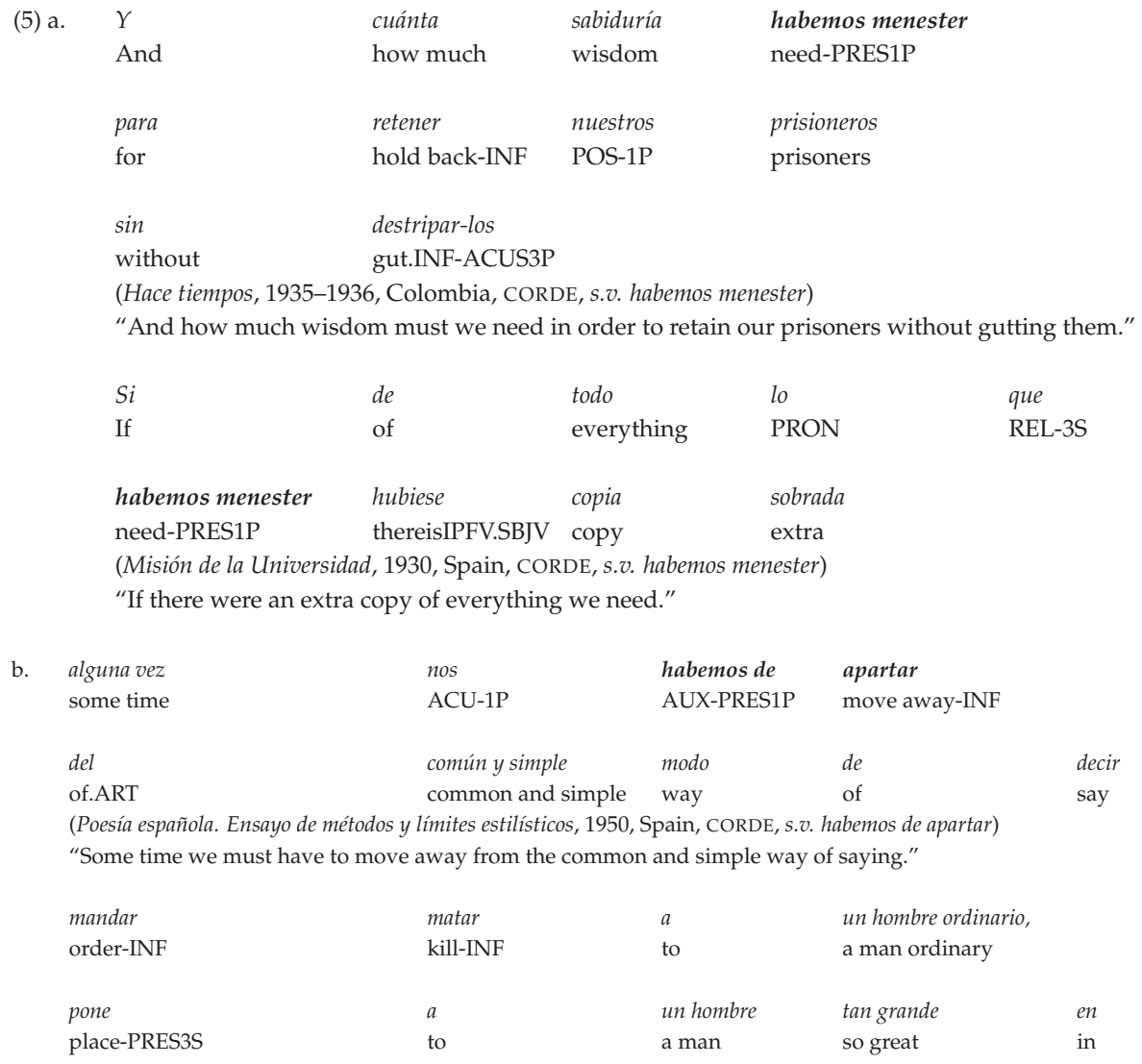




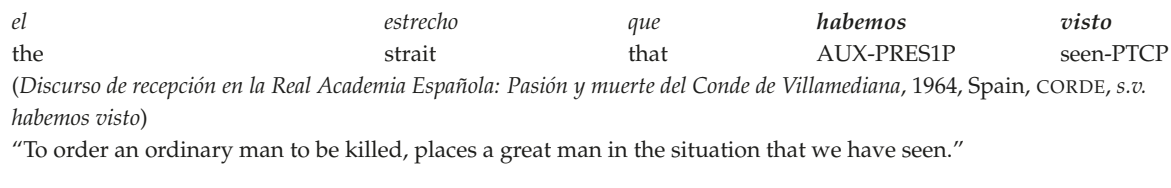

\begin{tabular}{|c|c|c|c|}
\hline $\begin{array}{l}y a \\
\text { already }\end{array}$ & $\begin{array}{l}\text { sabéis } \\
\text { know-PRES2P }\end{array}$ & $\begin{array}{l}\text { la } \\
\text { the }\end{array}$ & $\begin{array}{l}\text { voluntad } \\
\text { will }\end{array}$ \\
\hline $\begin{array}{l}\text { la Católica Reina mi Señora, } \\
\text { the My Lady the Catholic Queen }\end{array}$ & $\begin{array}{l}e ́ \\
\text { and }\end{array}$ & $\begin{array}{l}\text { yo } \\
\text { I }\end{array}$ & $\begin{array}{l}\text { habemos } \\
\text { AUX-PRES1P }\end{array}$ \\
\hline $\begin{array}{l}\text { tenido } \\
\text { had-PTP }\end{array}$ & $\begin{array}{l}e ́ \\
\text { and }\end{array}$ & $\begin{array}{l}\text { tenemos } \\
\text { have-PRES1P }\end{array}$ & $\begin{array}{l}\text { al } \\
\text { to.ART }\end{array}$ \\
\hline
\end{tabular}

Despite what we have previously said, the frequency of habemos grows in the 21st century, when the verb has an existential meaning, because, as is widely known, the agreement of haber in contemporary Spanish is a general and widely spread phenomenon, even though it is not always recorded in written form.

In my opinion, as stated in a previous study on haber's agreement (Hernández Díaz 2005), it is necessary to make a distinction between the creation of two different kinds of agreement, for they depend on different semantic, and, more importantly, pragmatic reasons. I am referring to the contrast in example (6).

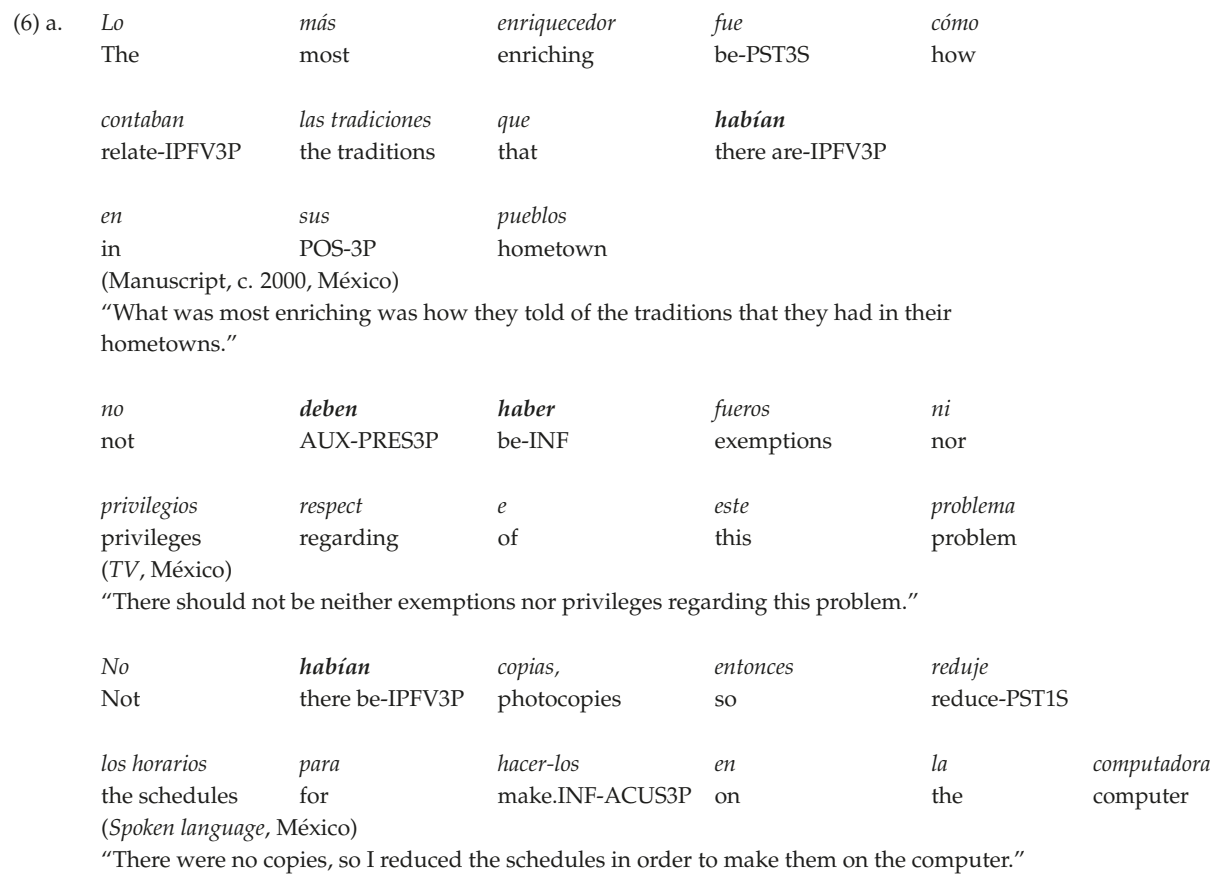




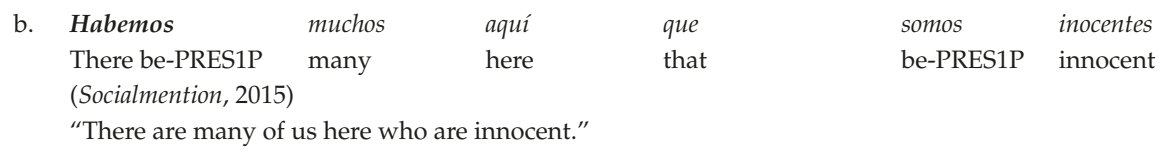

$\begin{array}{lllll}\text { yo } & \text { sé } & \text { que } & \text { habemos } & \\ \text { I } & \text { know-PRES1S } & \text { that } & \text { there be-PRES1P } & \\ \begin{array}{l}\text { muchos } \\ \text { many }\end{array} & \begin{array}{l}\text { que nos } \\ \text { who }\end{array} & \begin{array}{l}\text { sentimentos } \\ \text { feel-PRES1P }\end{array} & \begin{array}{l}\text { así } \\ \text { like this }\end{array} & \begin{array}{l}\text { y } \\ \text { and }\end{array} \\ \text { no } & \text { tiene } & \text { nada } & \text { de } & \text { malo } \\ \text { not } & \text { have-PRES3S } & \text { nothing } & \text { about } & \text { wrong }\end{array}$

(Socialmention, 2015)

"I know that there are many of us who feel this way and there is nothing wrong about it."

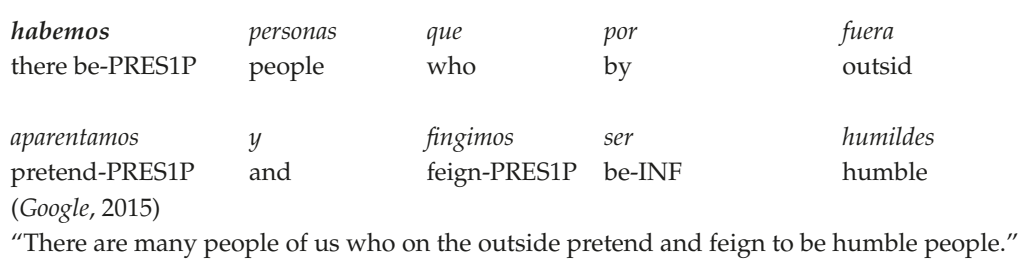

In both (6a) and (6b), the reanalysis of the element governed by the existential verb haber, as the subject of the sentence, is evident. This mechanism was defined as follows:

The change in the structure of an expression or kind of expression, which is not related to any immediate or essential modification in its superficial expression. (Langacker 1977, p. 58)

As different authors have stated (Company 2010; García 1990; Narrog 2007), a reanalysis might or might not have repercussions in formal expression but will definitely have repercussions on a conceptual level. Reanalysis is completed, in cases like example (6), because it has happened at an internal and external level of expression and because of the way in which it manifests itself or becomes updated in the agreement.

As we know, reanalysis is a major mechanism for grammaticalization and for linguistic change in general, mainly because it is a prerequisite for the implementation of change through analogy: a process that modifies shallow evidences and that spreads reanalysis' effects not only within the same linguistic system but also inside the speaking community. The analogy that caused the grammatical uses I am interested in was the intransitive mono-argument constructions' formal structure, because whenever a predicate has only one argument, it will prototypically be the subject of the sentence. The first example in (6a) shows a very evident analogy because the existential verb habian is coordinated with existian, which makes the two sentences look syntactically equal in the eyes of the speaker.

The development of agreement in habemos is a case of refunctionalization, except for the one exhibited in (6a), because it does not only imply the reanalysis of an existing entity as the sentence's subject but also the reuse of what is almost a junk form or a very marginal one in standard Spanish, as we have seen. Based on the results shown in Table 1, we can attest that the rotation of habemos and hemos seems to have been related, at some point, to the former's possessive value and that, once it lost this value, habemos was occasionally kept as an auxiliary verb. Keeping both forms, then, turned out to be unnecessary. Therefore, habemos became a morphological archaic case of hemos but in terms of system and frequency the former was practically considered to be 'junk.' According to Lass (1988, p. 36), there are only three outcomes for a residual expression: (1) complete loss; (2) remaining as waste without a specific function; or (3) remaining and being systematically used for another purpose, 
instead of being left aside. The third option is defined by Lass as exaptation and, according to the results in Table 3, that is precisely what happened to habemos.

Table 3. Recorded meaning of habemos (avemos).

\begin{tabular}{|c|c|c|c|c|c|c|}
\hline & & Possessive & Auxiliary & Existential & Prescriptive Use & Other Uses \\
\hline XIII & CORDE & $\begin{array}{c}7 \% \\
(27 / 373)\end{array}$ & $\begin{array}{c}93 \% \\
(346 / 373)\end{array}$ & - & - & - \\
\hline XIV & CORDE & $\begin{array}{c}10 \% \\
(13 / 124)\end{array}$ & $\begin{array}{c}90 \% \\
(111 / 124)\end{array}$ & - & - & - \\
\hline $\mathrm{XV}$ & CORDE & $\begin{array}{c}21 \% \\
(106 / 496)\end{array}$ & $\begin{array}{c}79 \% \\
(390 / 496)\end{array}$ & - & - & - \\
\hline XVI & CORDE & $\begin{array}{c}8 \% \\
(306 / 3715)\end{array}$ & $\begin{array}{c}92 \% \\
(3409 / 3715)\end{array}$ & - & - & - \\
\hline XVII & CORDE & $\begin{array}{c}10 \% \\
(135 / 1411)\end{array}$ & $\begin{array}{c}90 \% \\
(1276 / 1411)\end{array}$ & - & - & - \\
\hline XVIII & CORDE & $\begin{array}{c}2 \% \\
(2 / 83)\end{array}$ & $\begin{array}{c}98 \% \\
(81 / 83)\end{array}$ & - & - & - \\
\hline XIX & CORDE & $\begin{array}{c}28 \% \\
(29 / 105)\end{array}$ & $\begin{array}{c}59 \% \\
(62 / 105)\end{array}$ & - & - & $\begin{array}{c}13 \% \\
(14 / 105)\end{array}$ \\
\hline \multirow{2}{*}{$x x$} & CORDE & $\begin{array}{c}8 \% \\
(11 / 143)\end{array}$ & $\begin{array}{c}83 \% \\
(119 / 143)\end{array}$ & $\begin{array}{c}8 \% \\
(12 / 143)\end{array}$ & $\begin{array}{c}1 \% \\
(1 / 143)\end{array}$ & - \\
\hline & CREA & $\begin{array}{c}3 \% \\
(2 / 57)\end{array}$ & $\begin{array}{c}39 \% \\
(22 / 57)\end{array}$ & $\begin{array}{c}47 \% \\
(27 / 57)\end{array}$ & $\begin{array}{c}2 \% \\
(1 / 57)\end{array}$ & $\begin{array}{c}9 \% \\
(5 / 57)\end{array}$ \\
\hline \multirow{2}{*}{ XXI } & Google ${ }^{++}$ & - & $\begin{array}{c}2 \% \\
(4 / 160)\end{array}$ & $\begin{array}{c}63 \% \\
(100 / 160)\end{array}$ & $\begin{array}{c}34 \% \\
(55 / 160)\end{array}$ & $\begin{array}{c}1 \% \\
(1 / 160)\end{array}$ \\
\hline & SocialM & - & - & $\begin{array}{c}98 \% \\
(105 / 107)\end{array}$ & $\begin{array}{c}2 \% \\
(2 / 107)\end{array}$ & - \\
\hline
\end{tabular}

\footnotetext{
${ }^{\dagger}$ Eventhough CREA shows 58 results of habemos, one of these was left out because habernos was mistakenly typed as habemos (tú y yo podríamos habemos casado). ${ }^{+t}$ I took the first 100 existential cases of habemos: 55 correction cases, 4 cases used as auxiliary and one more corresponding to the explanation of the Latin expression habemus papam (VERB + ACCUSATIVE CASE).
}

Even though grammarians in the 19th century identify the use of habemos with the meaning 'existir' ('to exist') as a mistaken agreement, results show that during the 20th and 21st century exaptation was the solution for habemos. This verb form was marginally used as an auxiliary or with a possessive meaning during the 19th and 20th centuries. However, during the 20th century and during the first fourteen years of the 21st century, it regained strength not only to express existence-for habemos with existential meaning does not merely mean that algo está o existe en alguna parte ('something is or exists somewhere') - but also as the verb form that allows the speaker to include himself as member of a group or class. Such a group exhibits a clear set of characteristics and is located inside space and time coordinates_real and metaphorical —as is shown in example (7). Thus, the recovery of habemos involved its refunctionalization, through subjectivization, as well. Moreover, since habemos, unlike other impersonal existential verb forms, was reused as an existential verb with the option to indicate the grammatical person, in some way, it might be seen as an exaptation process. 


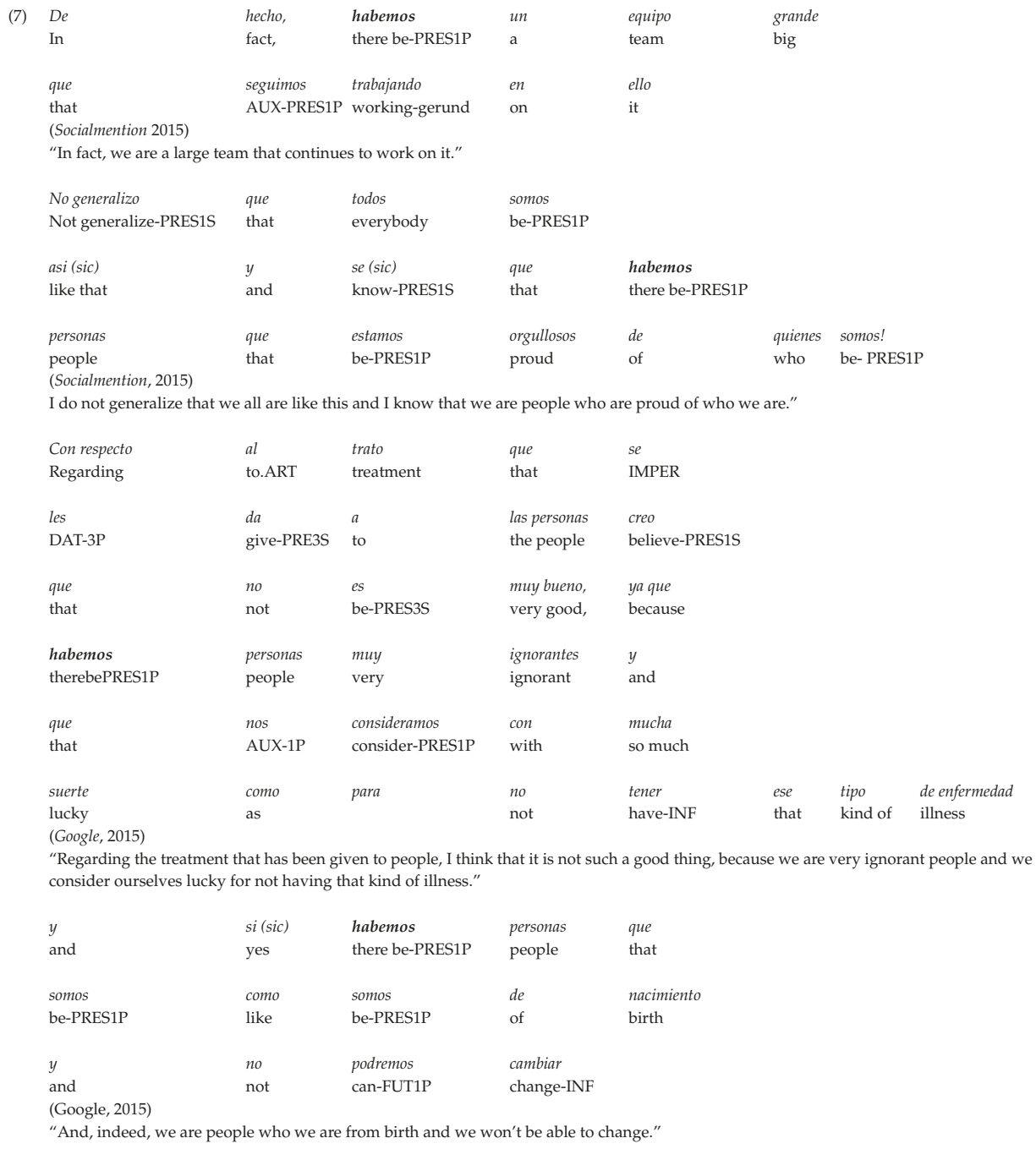

Going back to the results of Table 3, I deem it necessary to explain the two far right columns: 'prescriptive use' and 'other use.' The former attracts my interest because, in Google, these cases equal $34 \%$, that is, 55 of the 160 first reported examples. I decided to classify them as 'prescriptive use' because they are, in a sense, an expansion of suggestions by grammar books to avoid agreement between the verb haber and a mono-argument noun phrase. These results refer to articles, pages, blogs or chats that describe this agreement as incorrect and they censure it. This shows a genuine interest in the subject, as well as the frequency of the phenomenon, for we can assume that prescription occurs as often as there is a violation of a rule. Then, to the far right, the 'other use' column gathers fixed phrases where haber is used with possessive meaning but it does not make any sense to classify them as truly transitive uses. Taking this into account, the refunctionalization of the verb form habemos seems to be almost complete. Figure 1 shows the refunctionalization of habemos diachronically. 


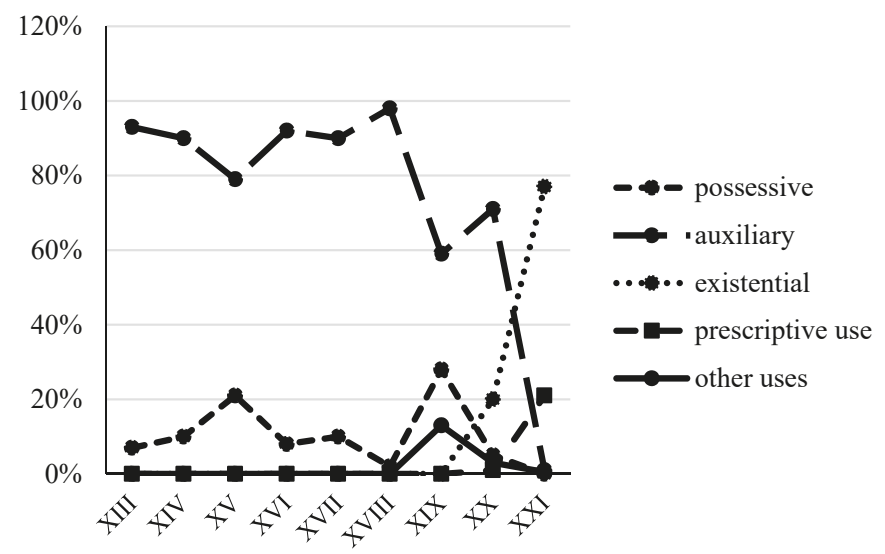

Figure 1. Meaning of habemos (avemos). Refunctionalization.

There is no doubt that the refunctionalization of habemos may be explained as a change through subjectivization, because grammatical alternatives, which are reduced to formal options dissociated from meaning in some theories, are studied in change theories as carriers of meaning. Such meaning is defined by different perception forms in a situation, rather than by different objective or fact conditions. Exposing the figurative condition of language allows us to approach rotation as part of the common pragmatic meaning of language, where we can see that change in shape also implies change in meaning.

Having observed an increasing tendency in correcting the agreement of habemos, we could ask ourselves why there is insistence on exaptation. The answer lies in the hypothesis 'change in shape implies change in meaning' because, subjectively, the advantage of habemos over hay or even over other verbs that can give constructions an existential sense, is that the speaker is able to include himself in the referred event as a directly affected member of the situation. It is worth mentioning that existential sentences with habemos in the corpus usually refer to events where the speaker, as part of the subject, plays the part of 'theme.' A theme that is somehow affected by the described situation, because sentences include theme as being part of a class with specific circumstances, frequently deemed negative (for example signs of vulnerability), as shown in italics in (8). 


\begin{tabular}{|c|c|c|c|}
\hline habemos & personas & que & le \\
\hline there be-PRES1P & people & who & DAT-3S \\
\hline damos & fiebre & a & la \\
\hline give-PRES1P & fever & to & the \\
\hline
\end{tabular}

(Doña Bárbara, 1929, Venezuela, CORDE, s.v. habemos personas)

"There are those of us who give fever to fever."

\begin{tabular}{|c|c|c|c|c|}
\hline $\begin{array}{l}\text { hay, } \\
\text { there be-PRES3S }\end{array}$ & $\begin{array}{l}\text { habemos } \\
\text { there } \\
\text { be-PRES1P }\end{array}$ & $\begin{array}{l}\text { todavía } \\
\text { still }\end{array}$ & & \\
\hline $\begin{array}{l}\text { militares } \\
\text { militaries }\end{array}$ & $\begin{array}{l}\text { pundonorosos, } \\
\text { honorable }\end{array}$ & $\begin{array}{l}\text { para } \\
\text { for }\end{array}$ & $\begin{array}{l}\text { defender } \\
\text { defend-INF }\end{array}$ & \\
\hline $\begin{array}{l}\text { los intereses } \\
\text { the interests }\end{array}$ & $\begin{array}{l}\text { del } \\
\text { of.ART }\end{array}$ & $\begin{array}{l}\text { pueblo } \\
\text { people }\end{array}$ & $\begin{array}{l}y \\
\text { and }\end{array}$ & $\begin{array}{l}\text { de la } \\
\text { of the }\end{array}$ \\
\hline
\end{tabular}

(El Papa verde, 1954, Guatemala, CORDE, s.v. habemos)

"There are still honorable men, including me, to defend the interests of the people and of the homeland."

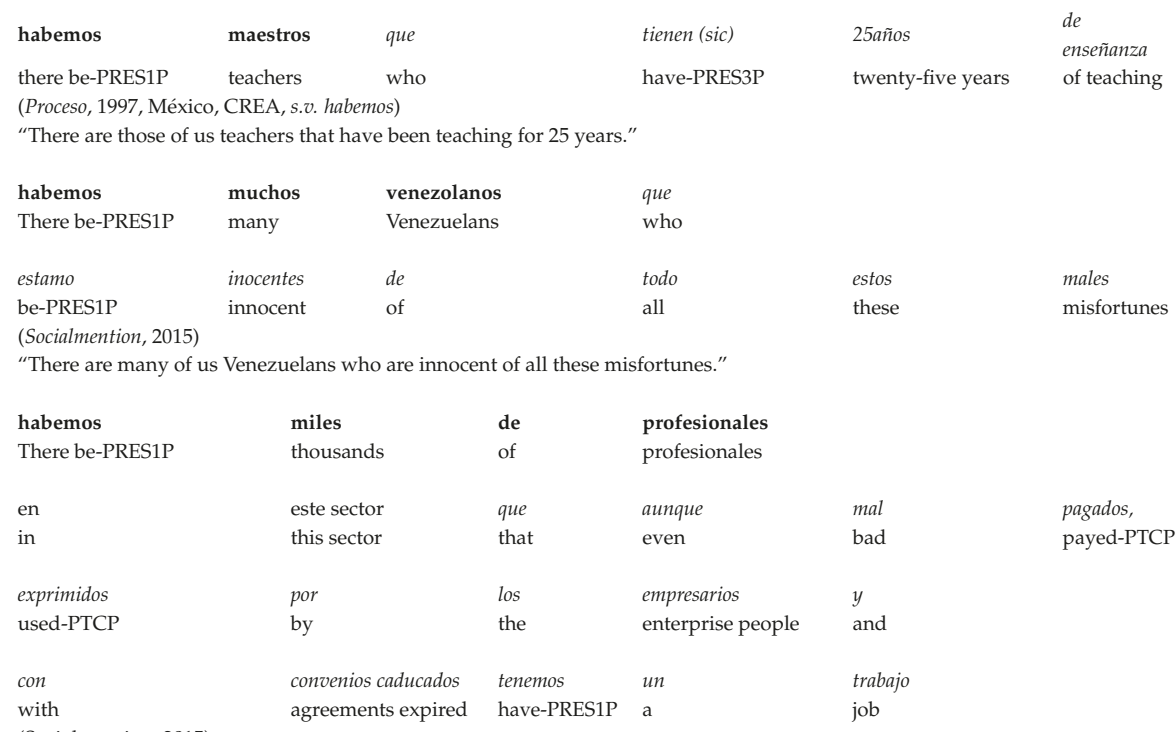

(Socialmention, 2015)

"There are thousands of us professionals in this sector that though poorly payed, exploited by the businessmen with bad contracts, we still have a job."

Thus, the refunctionalization of habemos is another way in which the Spanish expresses a change of mood within the syntactic subject. This is the reason why, even though the phenomenon is constantly condemned, its presence is a fact, due to the communicative advantages it has in pragmatics.

The cooptation of habemos to mean the 'existence of a class to which the speaker belongs or includes himself' is possible thanks to the personal inflectional morpheme. As we know, recycling of the form may be or may not directly related to its former or original use or can be used marginally. For habemos, we consider it is the second case because the marginal relationship lies in the personal form of the verb but it is not related to its previous possessive value. It is related to an existential value it rarely had in Latin and which increased in Old Spanish. The recycling and recovery of habemos to include the speaker as part of the subject is overwhelming, if we consider the most frequent combinations of habemos. In accordance with Google web browser results, in frequency order they are as follows: habemos personas que ... ('There are those of us people that ... ') (393,000 cases), habemos gente que ... ('There are those of us that ... ') $(389,000)$, habemos algunos que ... ('There are some of us 
people that ... ') $(305,000)$, habemos algunas que ... ('There are some of us women that ... ') $(229,000)$, habemos quienes ... ('There are those of us who ... ') (225,000 cases), habemos hombres que ... ("There are those of us that ... ') $(221,000)$, habemos mujeres que ... ('There are those of us women that ... ') $(219,000)$, habemos muchos que ... ('There are many of us that ... ') (174,000 cases).

In approaching the end of this analysis, I would like to make it clear that my approach to haber has been a many-angled diachronic one, inserted in grammaticalization and reanalysis theory. I would also like to add that I did not find those theories useful in explaining refunctionalization regarding the development of agreement or the special case of habemos, because we are not dealing with a gradual one-way phenomenon in Spanish language history. It is surprisingly odd, within these theories, to find a practically useless obsolete word regaining expressive strength. However, under light shed by refunctionalization and by subjectivization, as an exaptation case, the change turns out to be natural and transparent. Thus, I consider that the development of agreement in haber, specifically in habemos, can be partially explained from on the grounds of grammaticalization. I also consider that both grammaticalization and exaptation allow us to explain a sudden phenomenon that neither has a unidirectional behaviour, nor ends in a grammatical or more grammatical form than the one at the beginning. It is a phenomenon with a form that reinserts itself, inside the verbal paradigm by building a new paradigm, through reanalysis and refunctionalization, due to subjective and pragmatic value assessment.

\section{Conclusions}

We can conclude that it is possible to account for the diachrony of habemos, in the history of the Spanish language, as a refunctionalization case. Through this concept, we can explain changes that do not follow a unidirectional trajectory, are not gradual and do not end with the creation of more grammatical forms than the ones from previous stages.

In accordance with data gathered in this analysis, change - or rather the recycling of habemos - has been possible due to communicative advantages that other existential verbs do not have; particularly, the possibility to include the speaker in an existential sentence and as member of a group or a class with well-defined characteristics. Thus, in order to explain the whole diachrony of the verb haber, from possession to existential domain, we must acknowledge the relevant role played by processes such as refunctionalization, subjectivization and to some degree, exaptation.

Funding: This research received no external funding.

Acknowledgments: I would like to show my gratitude to Mar Garachana and Dorien Nieuwenhuijsen for their work during the preparation and the edition of this number, and I thank 2 "anonymous" reviewers for their suggestions and comments.

Conflicts of Interest: The author declares no conflict of interest.

\section{Appendix A}

Main corpus

CORDE $=$ Real Academia Española, Data base (CORDE) [Online]. Corpus Diacrónico del Español. $<$ http:/ / www.rae.es> [December 2014].

CREA = Real Academia Española, Data base (CREA) [Online]. Corpus de Referencia del Español Actual. <http://www.rae.es> [December 2014].

Google $=$ Internet search engine $<$ http: / / www.google.com.mx $>$ [January 2014].

Social $\mathrm{M}=$ Socialmention.com. Real-time social media search and analysis. <http://www. socialmention.com>. [January 2014]. 


\section{Appendix B}

Virgilio = Virgilio, Eneida, vol. 1, Madrid: CSIC, 2009.

Cid = Anonymous, Cantar de mio Cid. Texto gramática y vocabulario, vol. 3, Ramón Menéndez Pidal (ed.), Madrid: Espasa Calpe, 1944-1945.

Setenario = Alfonso X, Setenario, Kenneth H. Vanderford (ed.), Barcelona: Crítica, 1984.

$C G=$ Alfonso $\mathrm{X}$, Primera crónica general de España, Ramón Menéndez Pidal (ed.), Madrid:

Gredos, 1955.

\section{References}

Bello, Andrés. 1997. Gramática de la lengua castellana. Madrid: EDAF. First published 1847.

Bentivoglio, Paola, and Mercedes Sedano. 1989. Haber: ¿Un verbo impersonal? Un estudio sobre el español de Caracas. In Estudios sobre el español de América y lingüística afroamericana. Ponencias presentadas en el 45 Congreso internacional de americanistas. Edited by De Granda G. Bogotá: Instituto Caro y Cuervo, pp. 59-81.

Blas Arroyo, José L. 2016. Entre la estabilidad y la hipercorrección en un antiguo 'cambio desde abajo': Haber existencial en las comunidades de habla castellonenses. Lingüística Española Actual 38: 69-108.

Bustos Gisbert, Eugenio de, and Jesús Moreno Bernal. 1992. La asimetría 'hemos,' 'habéis'. In Actas del II Congreso Internacional de Historia de la Lengua Española. Edited by M. Ariza, R. Cano, J. M. Mendoza and A. Narbona. Madrid: Pabellón de España, vol. 1, pp. 307-21.

Castillo Lluch, Monica, and Álvaro S. Octavio de Toledo. 2016. Habemos muchos que hablamos español: distribución histórica de la concordancia existencial en primera persona de plural. In En torno a haber: Construcciones, usos y variación desde el latín hasta la actualidad. Edited by Carlota de Benito Moreno and Álvaro S. Octavio de Toledo y Huerta. Bern: Peter Lang, pp. 111-68.

Claes, Jeroen. 2014. Sociolingüística comparada y gramática de construcciones: Un acercamiento a la pluralización de haber en las capitales antillanas. Revista Española de Lingüística Aplicada 27: 338-64. [CrossRef]

Claes, Jeroen. 2016. Cognitive, Social and Individual Constraints on Linguistic Variation. A Case Study of Presentational 'Haber' Pluralization in Caribbean Spanish. Berlin: De Gruyter.

Company, Concepción. 2010. Reanálisis, ¿mecanismo necesario de la gramaticalización? Una propuesta desde la diacronía del objeto indirecto en español. Revista de Historia de la Lengua Española 5: 35-66.

Garachana Camarero, Mar. 1994. El proceso de sustitución de aver por tener en el siglo XV. Master's dissertation, Universidad de Barcelona, Barcelona, Spain.

Garachana Camarero, Mar. 1997. Acerca de los condicionamientos cognitivos y lingüísticos de la sustitución de 'aver' por 'tener'. Verba. Anuario galego de filoloxia 24: 203-35.

García, Erica C. 1990. Reanalysing actualization and actualizing reanalysis. In Historical Linguistics 1987. Edited by Henning Andersen and E. F. K. Koerner. Amsterdam: John Benjamins, pp. 141-60.

Gili Gaya, Samuel. 1943. Curso superior de sintaxis española. México: Ediciones Minerva.

Girón Alconchel, José L. 2004. Cambios gramaticales en los Siglos de Oro. In Historia de la lengua española. Edited by R. Cano. Barcelona: Ariel, pp. 859-93.

Hernández Díaz, Axel. 1999. La competencia de haber y tener como verbos de posesión en el español. Bachelor's thesis, Universidad Nacional Autónoma de México, Mexico City, Mexico.

Hernández Díaz, Axel. 2005. Habían preguntas de todas las áreas vs. habemos muchos que estamos en contra: dos casos distintos de generación de concordancia. Paper presented at the conference of XIV Congreso Internacional de la Asociación de Lingüística Filología de América Latina, Monterrey, Mexcio, October $19-23$.

Hernández Díaz, Axel. 2006a. Posesión y existencia. La competencia de haber y tener en la posesión y haber existencial. In Sintaxis histórica del español. Edited by Concepción Company Company. México: Universidad Nacional Autónoma de México \& Fondo de Cultura Económica, vol. 2, pp. 1053-60.

Hernández Díaz, Axel. 2006b. Gramaticalización y reanálisis. La concordancia del verbo haber existencial en la diacronía del español. In Actas del VI Congreso Internacional de Historia de la Lengua Española. Madrid: Arco Libros, vol. I, pp. 799-811.

Hernández Díaz, Axel. 2007. Las construcciones existenciales en el español. Estructura y diacronía. Ph.D. dissertation, Universidad Nacional Autónoma de México, Mexico City, Mexico. 
Langacker, Ronald W. 1977. Syntactic reanalysis. In Mechanisms of Syntactic Change. Edited by Charles N. Li. Austin: University of Texas Press, pp. 57-139.

Lass, Roger. 1988. How to do things with junk: Exaptation in language evolution. Stellenbosch Papers in Linguistics 17: 33-62. [CrossRef]

Lass, Roger. 1990. How to do things with junk: exaptation in language evolution. Journal of Linguistics 26: 79-102. [CrossRef]

Narrog, Heiko. 2007. Exaptation, grammaticalization and reanalysis. California Linguistic Notes 32: 1-26.

Pato, Enrique. 2016. La pluralización de haber en español peninsular. In En torno a haber: Construcciones, usos y variación desde el latín hasta la actualidad. Edited by Carlota de Benito Moreno and Álvaro S. Octavio de Toledo y Huerta. Bern: Peter Lang, pp. 357-91.

Real Academia Española. 1973. Esbozo de una nueva gramática de la lengua española. Madrid: Espasa Calpe.

RAE/ASALE (Real Academia Española \& Asociación de Academias de la Lengua Española). 2009. Nueva gramática de la lengua española. Madrid: Espasa Calpe.

Rodríguez Molina, Javier. 2010. La gramaticalización de los tiempos compuestos en español antiguo: Cinco cambios diacrónicos. Ph.D. dissertation, Universidad Autónoma de Madrid, Madrid, Spain.

Rodríguez Molina, Javier. 2012. La reducción fonética avemos cantado > hemos cantado en español antiguo: Nuevos datos y nuevas hipótesis. In Estudios de filología y lingüística españolas. Nuevas voces en la disciplina. Edited by Enrique Pato and Javier Rodríguez Molina. Bern: Peter Lang, pp. 167-233.

Seco, Manuel. 1989. Gramática esencial del español. Madrid: Espasa Calpe.

Traugott, Elizabeth Closs. 2004. Exaptation and grammaticalization. In Linguistic Studies Based on Corpora. Edited by M. Akimoto. Tokyo: Hituzi Syobo, pp. 133-56.

Vaquero, María T. 1978. Enseñar español, pero ¿qué español? Boletín de la Academia Puertorriqueña de la Lengua Española 6: 127-46.

(C) 2019 by the author. Licensee MDPI, Basel, Switzerland. This article is an open access article distributed under the terms and conditions of the Creative Commons Attribution (CC BY) license (http:/ / creativecommons.org/licenses/by/4.0/). 


\title{
Article \\ Grammatical Words and Spreading of Contexts: Evidence from the Spanish Preposition $a$
}

\author{
Concepción Company Company \\ Instituto de Investigaciones Filológicas, Universidad Nacional Autónoma de México,Circuito Mario de la Cueva, \\ s.n., Ciudad de la Investigación en Humanidades, Ciudad de México 04510, Mexico; \\ concepcion.company@gmail.com
}

Received: 2 January 2019; Accepted: 1 February 2019; Published: 15 February 2019

\begin{abstract}
The paper shows that when grammatical words are involved, context is then the unit of language change. Certain changes consist in an active spreading of a form to new contexts, without changing the category or grammatical status of the form; in these cases, context must be considered the unit of language change. The empirical evidence is the diachrony of the Spanish preposition $a$ 'to'. Throughout history, this preposition pervasively extended to new and different contexts, but the form $a$ never changed, remaining a grammatical preposition with a basic meaning of 'directive telicity towards a goal' (goal maybe locative, temporal, transitivity, finality, discursive, etc.). The paper labels this kind of change as 'context construction', and considers it an analogical extension induced by context. Finally, to test whether the diachrony of $a$ is grammaticalization or not, the paper reviews fourteen related theoretical concepts, checking them against the diachronic evidence of the preposition $a$.
\end{abstract}

Keywords: context; grammaticalization; exaptation; refunctionalization; analogical extension

\section{Introduction. The Theoretical Problem ${ }^{1}$}

The history of the Spanish preposition $a$ 'to' constitutes both a striking case in general syntactic diachrony and a challenge for several theoretical frameworks of language change. It especially presents a challenge for Grammaticalization, because the preposition underwent many syntactic changes without modifying its basic, general meaning throughout the history of Spanish, and without modifying its category status of grammatical preposition. The changes, as a whole, may be characterized as a very active spread of the preposition into new and different distributions and contexts, but the form a never changed, always being a grammatical preposition, and always having a basic meaning of 'directive telicity towards a goal', the goal may be locative, temporal, final, inmediate or mediate goal of transitivity, modal goal, discourse goal, the hearer as a goal, etc. It is a case of change of contexts and not a case of change of the status of the form. There is no polysemy of $a$, there is a great context polifuncionality, and there is also the creation of new constructions with $a$. I will label this kind of change as a 'pattern of pervasive spreading of contexts'.

Each new context is an extension of the previous one, via metonymic or metaphorical elaborations, and each new context has gradually moved away from the locative context encoded by the classical Latin preposition $a d$, which is the etymon of the Spanish $a$. The progress as regards to the context is, then, the expected one in diachronic syntax. However, the behavior of the preposition is not the expected one in diachronic syntax, because it maintained its grammatical status, and always coded

1 A preliminar version of this paper was read in Heidelberg, March 2015, at the 20th Deutscher Hispanistentag. I am indebted to Virginia Bertolotti, for a very careful and critical reading of a preliminary version of this paper. Her comments and dialogue improved the result. Also, my gratitude to Rosa Espinosa Elorza for her insights on some zones on this paper. I am indebted to two anonymous readers. Errors, obviously, are mine. 
'directive telicity towards a goal'; the goal being of different kinds, as I said above, locative, temporal, purposive, modal, imperative, discoursive, etc. (cf. $\$ 2$ below).

Table 1 (apud Company and Flores 2014, p. 1328) shows schematically the pervasive spreading of contexts undergone by the Spanish preposition $a$ in the history of Spanish. The growing line $a \rightarrow$ $\boldsymbol{a} \rightarrow \boldsymbol{a}$, with a bigger $a$ in each step, does not mean polysemy of $a$ nor changes in the preposition itself, it only means the gradual and constant diachronic spreading of the preposition to new contexts. The lines in the scheme reflect, to a certain degree, the diachronic stages of the advance of $a$ to new contexts, and also reflect the cumulative or stratified effect (Hopper 1991) produced by any syntactic change. For simplicity, the scheme represents only ten contexts, but there are many more; the historical depth of this change, still in progress, is also very old; it begun, at least, in Late Latin.

Table 1. Pervasive extension of preposition a 'to' into new contexts ${ }^{\dagger}$.

\begin{tabular}{|c|c|c|c|c|c|c|c|c|c|}
\hline$a$ & $\vec{a}$ & $\rightarrow a$ & $\rightarrow a$ & $\rightarrow \boldsymbol{a}$ & $\rightarrow a$ & $\rightarrow a$ & $\rightarrow \boldsymbol{a}$ & $\rightarrow \boldsymbol{a}$ & $\rightarrow a$ \\
\hline LOC & $\begin{array}{c}\text { LOC } \\
\text { IO }\end{array}$ & $\begin{array}{c}\text { LOC } \\
\text { IO } \\
\text { HDO }\end{array}$ & $\begin{array}{c}\text { LOC } \\
\text { IO } \\
\text { HDO } \\
\text { TEMP }\end{array}$ & $\begin{array}{c}\text { LOC } \\
\text { IO } \\
\text { HDO } \\
\text { TEMP } \\
\text { FUT }\end{array}$ & $\begin{array}{c}\text { LOC } \\
\text { IO } \\
\text { HDO } \\
\text { TEMP } \\
\text { FUT } \\
\text { PURP }\end{array}$ & $\begin{array}{c}\text { LOC } \\
\text { IO } \\
\text { HDO } \\
\text { TEMP } \\
\text { FUT } \\
\text { PURP } \\
\text { IDO }\end{array}$ & $\begin{array}{c}\text { LOC } \\
\text { IO } \\
\text { HDO } \\
\text { TEMP } \\
\text { FUT } \\
\text { PURP } \\
\text { IDO } \\
\text { MOD }\end{array}$ & $\begin{array}{c}\text { LOC } \\
\text { IO } \\
\text { HDO } \\
\text { TEMP } \\
\text { FUT } \\
\text { PURP } \\
\text { IDO } \\
\text { MOD } \\
\text { IMP }\end{array}$ & $\begin{array}{c}\text { LOC } \\
\text { IO } \\
\text { HDO } \\
\text { TEMP } \\
\text { FUT } \\
\text { PURP } \\
\text { IDO } \\
\text { MOD } \\
\text { IMP } \\
\text { DISC }\end{array}$ \\
\hline
\end{tabular}

${ }^{\dagger} \mathrm{LOC}=$ locative; $\mathrm{IO}=$ indirect object; $\mathrm{HDO}=$ human direct object; TEMP = circumstantial temporal complements; FUT $=$ temporal future in the periphrasis ir a + infinitive; PURP $=$ purpose; IDO = inanimate direct object; $\mathrm{MOD}=$ modal contexts; IMP = imperative; DISC = discursive contexts

Pervasive spreading into new and more varied contexts with no change in the category status of the form or construction involved in those contexts is not a type of change that is typically considered within the research framework of grammaticalization. In fact, the well-known classical definitions of grammaticalization in (1) posit that language change is characterized by a change in the grammatical status of a form or construction (e.g., a change from a lexical to a grammatical form, or a change from a grammatical form to a more grammatical one), and that these developments are driven by changes in contextual use, context being only the medium through which forms or constructions acquire a new grammatical status or a new grammatical category. The definitions in (2) do not mention context or take it into account at all. Probably, context is absent from many definitions because it is obvious that forms need context and actual use for changing; that is, context is taken for granted in grammaticalization, although all works point out the local nature of syntactic change, that is, they recognize that change always takes place within specific contexts (Diewald 2002; Heine 2002). In consequence, specialized theoretical literature does not bear in mind changes such as the one analyzed here.

(1) a. A process by which a lexical form or construction, in specific pragmatic and morphosyntactic contexts, assumes a grammatical function or by which an already-grammatical form or construction acquires an even more grammatical one (Kuryłowicz [1965] 1975, p. 69). ${ }^{2}$

b. Grammaticalization is the change whereby lexical items and constructions come in certain linguistic contexts to serve grammatical functions or grammatical items develop new grammatical functions (Traugott 2001).

2 This definition is present, almost literally, in many authors since (Meillet [1912] 1965). (Cf. Bybee et al. 1994, chp. 1; Company 2003; Heine et al. 1991, p. 2; Heine and Reh 1984, pp. 20-22; Hopper and Traugott 2003, chp. 1; Lehmann [1982] 1995) 
c. Grammaticalization refers to that part of the study of language change that is concerned with such questions as how lexical items and constructions come in certain linguistic contexts to serve grammatical functions or how grammatical items develop new grammatical functions [ ... ] grammaticalization refers most especially to the steps whereby items become more grammatical through time [ ... ] the change occurs only in a very local context (Hopper and Traugott 2003, pp. 1-2).

(2) a. Grammaticalization [...] by definition is a process of language change in which an expression moves away from the lexical pole and toward the grammatical pole (Geurts 2000, p. 781).

b. Lexical or less grammaticalized linguistic expressions are pressed into service for the expression of more grammaticalized functions (Heine 2003, p. 578).

Relating the above definitions to the Spanish preposition $a$, this word neither moved away from the lexical pole towards the grammatical pole, nor was it 'pressed into service' for more grammatical functions, because $a$ has always served grammatical functions. Even specialized literature considers it as an element that only establishes relations between two forms or constructions (Tullio 1997, pp. 41-42). Indeed, reference grammars often analyze this preposition as an empty form, lacking any meaning (Alcina and Blecua 1975, sct. 6.2.5). Obviously, the preposition $a$ increased its frequency across the history of Spanish, because it appears in many more contexts, but an increase in frequency is not, by itself, a signal of grammaticalization. At best, heightened frequency is a symptom that there may be certain changes in progress.

The theoretical problem of the definitions of grammaticalization above is twofold: first, how is it that a word, which is already very grammatical, becomes more grammaticalized? Second, is it possible to consider context change as a kind of grammaticalization? In this paper I address these questions by analyzing the role of context in language change. In doing so I hope to establish a dialogue between the different approaches and the types of grammaticalization and the Spanish diachronic data of $a$ while determining the extent to which context is responsible for developing the pattern of $a \rightarrow \boldsymbol{a} \rightarrow \boldsymbol{a}$.

This paper contains three proposals. The first is that context may be, in some cases, the 'unit of change', besides being simply a 'locus of change'. Context is understood here neither in a restricted grammatical sense, nor in the traditional meaning of narrative blocks. Instead, context is defined as a form or construction + a specific distribution where the form or construction enters into + optionally, other syntagmatic and/or prosodic units co-occurring with those forms or constructions. This definition, basically, fits with the 'construction grammar' framework analysis (Trousdale 2012; Hoffmann and Trousdale 2013; Traugott and Trousdale 2013). The second proposal of this paper is that it is necessary to leave the word level for some types of changes, and take into account both construction and context in order to fully understand some diachronic syntactic processes. Finally, this paper proposes that forms maintain their basic, general meaning for centuries. Forms enter into new contexts but these contexts are always more or less compatible with their general meaning. This stability guarantees that the progression of language change is neither haphazard nor chaotic.

This paper is organized in four sections besides this Introduction. In Section 2, the diachronic data related to preposition $a$ are presented, focusing on the new contexts and constructions in which the preposition appeared, and classifying the types of change corresponding to the new contexts with $a$. In Section 3, I summarize the various current research frameworks on grammaticalization, and specifically focus on the conceptual theoretical labels that relate to the Spanish diachronic data of preposition $a$. That is, in this section I try to establish a dialogue between theory and diachronic data in order to inform the diverse views on grammaticalization. In Section 4, I make a specific theoretical proposal for the kind of change consisting in pervasive spreading of contexts. Brief conclusions are in Section 5.

\section{Diachronic Data on Preposition $a$}

The basic meaning 'directive telicity towards a goal', which is inherent to preposition $a$ 'to', is maintained, as I said before, in all contexts, but the 'goal', which formally is the term of the 
preposition, may be of different types, displaying diverse semantic and grammatical nuances, forming different syntactic constructions which enter in very different contexts.

The goal, exemplified in (3-23), may be-among many other constructions-a locative complement (3), taken literally (3a) or metaphorically (3b), a temporal complement (4), a future time (5), a future time without specifying tense nor mood (6), a final purpose (7), an accomplished trajectory (8), a person which is the final locus of movement (9), a personal direct object (DO) (10), an inanimate DO (11)—DO is always the immediate goal of transitivity-, a recipient indirect object (IO) (12), which functions as the remote or ultimate goal of transitivity, an autonomous imperative event (13), a nominal construction with modal meaning (14), a nominal modality in construction with a verb (15), an adjective modality in construction with a verb (16), an adverbial modality with adverbs in -as (17), a future event in subordinate relative clause (18), a member acting as the goal of a comparison (19), an interrogative clause (20), a predicative construction close to a discourse marker (21), a fixed expression, an idiom, inherited from Latin (22), which should lack preposition in learned writing, because the Latin idiom is in ablative case, which internally already has a kind of preposition. The example (22) is a conclusive proof of the structural pervasive spreading of $a$ to new contexts, even the most reluctant ones, such as idioms. And the goal may be also a pragmatic one, an abstract location implying abstract movement (23). There are more types of context coding the goal, but (3)- (23) are enough examples to show the diversity of constructions, of contexts, and the diachronic stability of the preposition $a$. Only ( $3 a$ ) shows the original etymological context coming from Latin. ${ }^{3}$ The large and great variety of goals displayed in (3b-23) is the consequence of the diachronic spreading of $a$ to more varied contexts along the history of Spanish. ${ }^{4}$ In the examples, the verb and/or the noun and the prepositional phrase (PP) are in bold type to facilitate the identification of the construction and the context.

(3) a. hallé que abia enbiado a España con çiertas personas çinquenta y çinco mill y seysçientos y ochenta y seys pesos de oro (Letter, 1525, Mexico, CORDIAM) "I found that [he] had sent to Spain via certain people fifty-five thousand marcs."

b. me mandó a la mierda; y me dixo que no quería venir (Legal document, 1816, Mexico, CORDIAM)

"He sent me to hell and he told me he did not want to come"

(4) que fue el dicho dia que los mataron a la noche (Chronicle, 1598, United States, CORDIAM) "that day they killed them in [lit. to] the night"

(5) la condenada asma va a darme qué hacer (Emilia Pardo Bazán, Un viaje de novios, 1881, Spain, CORDE)

"this horrible asthma is going to give me problems."

(6) y con ello no tendrá pleyto ni gastos, cino que al comer gastará una gallina, al senar un pollo (Huamán Poma, Crónica, 1615, Peru, CORDIAM)

"doing it in that way, he'll never have problems nor spending, on the contrary, for lunch [lit. to the eat], he'll spend a poultry only, and for dinner [lit. to the have supper], a chicken only"

(7) el portador desta que es Diego Farias va a ese pueblo a un pleito de unos yndios (Letter, 1583, Colombia, CORDIAM)

"the person who carries this letter is Diego Farias, who goes to that village to a civil action about some Indians"

3 For a detailed analysis of the diachronic spreading of contexts, the chronological data, and a state of the art on the preposition $a$, cf. Company and Flores (2014, 2017).

4 For the metaphorical extensions and relationships linking all types of goals, cf. Company and Flores (2014). 
(8) Y llega el rey a por su novia y ve a la negra y le dice... (Anónimo, Cuentos populares españoles, ca. 1920, Spain, CORDE)

"and here is the king coming for [lit. to for] his fiancée and sees the black woman, and then he tells her..."

(9) Et lleguemosnos a él et gradescamosle su bien fazer (Anonymous, Calila, 1250, CORDE) "and we must come to him and thank him for his well done actions."

(10) Y llega el rey a por su novia y ve a la negra y le dice ... (Anónimo, Cuentos populares españoles, ca. 1920, Spain, CORDE)

"and here is the king coming for his fiancée and sees the black woman [lit. sees to the black woman], and then he tells her ..."

(11) los ácidos minerales destruyen al barniz que reviste al hueso del diente (Gazeta de México, 1787, apud Company and Flores 2014)

"mineral acids destroy the varnish [lit. to the varnish] of the teeth."

(12) Yo no puedo entender por qué dejó v.s. de enviar luego mi recaudo a el maestro Ávila (Santa Teresa, Cartas, 1560-1580, apud Company 2006)

"I cannot understand why you did not send my news to the master Avila"

(13) ¡Niña, a callar! (Alfonso Zurro, Farsas Maravillosas, 1987, España, CREA)

"baby, shut up [lit. to shut up]!"

(14) ¡Con lo fácil que era, pensaba, hacer una tortilla a la francesa! (Camilo José Cela, Esas nubes que pasan, 1945, Spain, CORDE)

"it is very easy, I thought, to make a plain omelette [lit. an omelette to the French way]."

(15) Unos jóvenes, andan a cangrejos, metidos en un riachuelo saltarín que brilla en la hondonada (Iñaki Linasazoro, La otra Guipúzcoa, 1969, CORDE)

"Some young men, seeking crabs [lit. walk to crabs], are into the jumping river."

(16) el aire olía mal, a cerrado, a podrido, a miseria (Almudena Grandes, Corazón helado, 2007, apud Company and Flores 2014)

"the air smells bad, closed, rotten, misery [lit. to closed, to rotten, to misery]."

(17) Cada quien toma veneno a sabiendas, de vez en cuando (José María Arguedas, El zorro de arriba y el zorro de abajo, 1969, Peru, CORDE)

"everyone takes poison knowingly [lit. to knowingly], from time to time."

(18) La categorización de los motivos ... constituye también un punto a señalar (José Luis Pinillos, Principios de psicología, 1975, España, CREA, apud Company and Flores 2014)

"the analysis of causes is a point that must be considered [lit. a point to consider]."

(19) Y como a listo (astuto diría yo) nadie le gana ... (Jenny E. Hayen, Por la calle de los anhelos, 1993, México, CREA, apud Company and Flores 2014)

"as to clever, nobody beats him."

(20) Por allí por la Alcarria no veis estas cosas, ¿a que no? (Sánchez Ferlosio, El Jarama, 1956, España, CORDE, apud Company and Flores 2014)

"there, in the Alcarria, you don't see those things, that's right? [lit. to which not?]."

(21) A ver si vamos haciendo lo que nos corresponde (Spontaneous speech, general Spanish)

"come on [lit. to see], we must do the correct things."

(22) La conductancia de un tubo es a grosso modo proporcional al cuadrado del potencial a que están los electrodos (Enrique Mata, La televisión. Fototelegrafía, 1929, Spain, CORDE) 
"Conductivity of the tube is, broadly speaking [lit. to broad mode], proportional to ... "

(23) Si no les pasa, pues bájense y ja la chingada! (Gerardo María, Fábrica de conciencias descompuestas, 1980, México, CREA)

"If you don't like it, get down and fuck you [lit. to the chingada]."

As examples (3-23) show, the term-goal of the preposition $a$ may be almost any category, lexical or syntactic: a nominal, noun or pronoun, an adjective, an adverb, a non-inflected verb, a prepositional phrase, a sentence, or a complete autonomous discourse event. Constructions formed with the preposition $a$ may be both argumental and non-argumental; they may be part both of nominal constructions and of verb constructions, may be both a dependent constituent and an autonomous discourse constituent, may appear both in free expressions and in lexicalized ones. That is, the preposition $a$ forms the most diverse constructions and it is, probably, along with preposition de (Rougiest 1980), the most productive preposition in Spanish given the very different syntactic expressions that it forms.

Besides the high variety of goals that may constitute the term of a prepositional phrase with $a$, PP- $a$, almost any category may be also the governing constituent of a PP- $a$ : a noun (example 24), an adjective (example 25), an adverb (example 26), a verb (example 27), another preposition (example 28), forming a prepositional sequence or a kind of composed preposition with $a$. The governing constituent and the preposition are in italics and in bold in the examples.

(24) Iglesias apuntó a las economías asiáticas como un ejemplo a seguir y elogió la forma muy rápida en que salieron de la crisis (El País, 5 Novembre 2002, Uruguay, CREA)

"Iglesias pointed out the Asian economies as an example to follow, and he praised ... "

(25) Lo esencial es invisible a los ojos (ABC, 16 February1996, Spain, CREA)

"The essential things are invisible to eyes"

(26) han recibido alguna o varias dosis de tratamiento antibiótico previamente a la obtención de las muestras (Revista Medicina General, 2003, Spain, CREA)

"The patients have taken various doses of antibiotic previously to obtaining the samples"

(27) el fenómeno mundial del fútbol miró a los reporteros gráficos, sonrió (El Tiempo, 12 June 1997, Colombia, CREA)

"The football star looked at the journalists [lit. looked to to the journalists] and smiled."

(28) produce ciento veinte y nueve mil, y doscientas cuarenta combinaciones de a dos sílabas (Ramón Campos, El don de la palabra en orden a las lenguas, 1804, Spain, CORDE)

"[chinese language] produces two forty hundred combinations with two syllables [lit. of to two syllables]."

In sum, the preposition $a$ goes through all Spanish grammar and goes through all lexical and syntactic categories. The reason, as I said, is that $a$ progressively entered new contexts diachronically, causing an exponential growth of contexts. With no doubt, two causes might have been working to motivate such spreading to new contexts and such constructional flexibility. On the one hand, the phonological lightness of this preposition, on the other hand, its locative basic meaning, because space, as it is well-known, is a fundamental cognitive grammatical area, prone to be reworked to encode new grammatical domains, such as time, modality, quality, result, etc.

The structural pattern of pervasive spreading of contexts of the preposition $a$ displays six manners of change, some of them exhibiting internal subtypes, but none of these changes affected the grammatical category of the preposition, as I said before. The etymological Latin context remains in Modern Spanish, as I said, because grammatical change is cumulative or stratified (Hopper 1991) that is, old and new distributions and contexts live together for centuries. 


\subsection{No Preposition $>$ Preposition a 'to': $\varnothing>a$}

This first type of change has two manifestations: a nominal one and a verbal one. The argumental functions DO and IO exemplify this first type of change well. In this case, the same function existed in the mother tongue, but the construction had the form of a noun phrase (NP) not of a PP, which is the structure which that function has in contemporary Spanish. Examples (29a) and (30a) show that DO and IO, respectively, had in Latin the form of an NP. The examples (29b) and (30b) exemplify the same argumental functions in Spanish, with an obligatory preposition $a$.

(29) a. Iudaeos ACC-DO-jewishs

"I have not harmed Jewishs."

b. No he perjudicado a los judíos

"I have not harmed Jewishs [lit. to the Jewish]"

(30) a.
a. Nuntiabant
hoc
idem
PAST-announce DO-this itself
(Allen and Greenough 1979, p. 229)
"they announced this fact to Curio."
b. Anunciaron esto mismo a Curio
"they announced this fact to Curio"

Curioni

The verbal manifestation of $\varnothing>a$ is related to periphrastic temporal constructions. In Old Spanish there was a two-verb construction, lacking any preposition linking them, as (31a) shows. From the 14th century onwards, this kind of periphrastic formation obligatorily takes the preposition $a$, introducing the second verb, as (31b) shows.

(31) a. Los christianos [ ... ] esforçaron se et fueron ferir en los turcos (Anonymous, Gran conquista de Ultramar, 1293, CORDE)

"Christians tried harder and went to destroy [lit. went destroy] Turkishs."

b. y éstos dejando quemar sus cosas, [ . . ] ], fueron a herir con gran velocidad en los del Clavero (Alonso de Maldonado, Hechos del maestre de Alcántara, ca. 1492, CORDE)

"and that people, allowing to burn their things, went to destroy the Clavero's people quickly."

\subsection{PP Headed by a Preposition Different from a 'to' > PP Headed by a 'to'}

This change is as follows: in Old Spanish, the construction had a PP form, but the introductory preposition was another than $a$, and over the time this last preposition ousted the oldest one. There are both verbal and non-verbal expressions where the preposition $a$ ousted other prepositions. The preposition ousted by $a$ is usually the preposition de 'of, from', but other prepositions were ousted too. Examples (32), (33), (34) and (35) display this second type of change.

In (32), the inchoative-verb construction took de 'of' in Old Spanish (32a), but from the 15th century onwards, $a$ ousted $d e$. Nowadays, inchoative verbs subcategorize PP- $a$ in Spanish (32b). Example (33) shows that the preposition $a$ also ousted the preposition de even with non-inchoative verbs; (33) is an unusual context for $a$, because the rule in Spanish is that despedir 'to say goodbye' subcategorizes a PP headed by de; however, (33) is a very classic example, although somewhat rare, from the first Spanish text totally written in Castilian, Cantar de mio Cid. ${ }^{5}$

5 Very probably, this $a$ comes from the Latin ablative preposition $a b$ 'from', which lost the final consonant, and merged with the Latin accusative preposition $a d$ ' to', which also lost the final consonant. Such Latin merger could have reinforced the invasive spreading of the Spanish preposition $a$. 
(32) a. Quando ellos se vieron fuera, en saluo comenzaron de fablar (Anónimo, Mocedades de Rodri-go, ca. 1400, CORDE)

"when they were outside, they began to talk [lit. began of talk]"

b. Libado el trago de la amistad, comenzaron a hablar (Gonzalo Zaldumbide, Égloga trágica, 1910, Ecuador, CORDE)

"Once drunk the glass of friendship, they began to talk"

(33) Espidiénsse al rey, con esto tornados son (Cid, v. 1914)

"they said goodbye to the king, and came back."

Non-verbal constructions displayed the same pattern of change, with $a$ ousting other prepositions. For instance, some temporal and locative complements with diverse prepositions in general Spanish, (34a) and (35a), introduced $a$ in the Argentinian dialect of Buenos Aires, and occasionally in some other American dialects, eliminating the old prepositions, as (34b) and (35b) show.

(34) a. nos vemos por la noche/nos vemos en la noche

"we'll see you in the night [lit. for/in the night]"

b. nos vemos a la noche

"we'll see you in the night [lit. to the night]"

(35) a. vivo en el 1300 de la avenida Insurgentes

"I live in Insurgentes avenue at 1300 [lit. in the 1300]"

b. vivo al 1300 de Corrientes

"I live in Corrientes avenue at $\mathbf{1 3 0 0}$ [lit. to the 1300]"

Some set phrases heading a PP also changed the original preposition by $a$, such as the following cases: de acuerdo con 'according with' > de acuerdo a 'according to'; con base en 'with basis in' > en base $a$ 'in basis to'; en honor de 'in honor of' > en honor $a$ 'in honor to'. Other constructions, lexicalized to some degree, but not so fixed as set phrases, displayed the same pattern in the history of Spanish: amor de la patria 'love of nation' > amor a la patria 'love to nation'; agua del tiempo 'water not cold' > agua al tiempo 'water not cold'. Examples in (36) show non-verbal constructions in which $a$ won the function; (36a) shows the oldest construction, (36b) the newest one, although the first attestations of $a$ are relatively old in these set phrases, as (36c) shows, an example from the year 1561. In many cases, both prepositions continue coexisting to encode the same construction, as in (37), showing the property of cumulative stratification of most syntactic changes.

(36) a. El dia 4 de acuerdo con algunos traidores, inventaron plaza en San Pedro (Legal document, 1781, Bolivia, CORDIAM)

"the fourth, according to [lit. according with] some traitors, they put a market in the main square."

b. en cada signo figuran las características generales de su hijo, de acuerdo a la fecha de nacimiento, que le darán pistas para saber cómo tratarlos (Expreso, 1 October 1991, Peru, CREA) "every star sign displays the traits of your son, according to his/her birthday date, giving you ..."

c. tenyendo en si de acuerdo a la calidad de su persona

(Administrative document, 1561, Peru, cordiam)

"having these things according to his qualities as person."

(37) Cada estado practica el contraterrorismo de acuerdo con las circunstancias del propio estado y de acuerdo a sus leyes (Cambio 16, 21 May 1990, Spain, CREA)

"every government exerts counter terrorism according to [lit. according with] its actual circumstances and according to the laws." 


\subsection{Subordinate Clause Headed by Conjunction que > Subordinate Clause Headed by a 'to'}

A subordinate relative clause, whose nominal antecedent is an abstract noun, meaning 'meeting', 'time', 'event', 'fact', 'conference', etc., may begin the predication with the preposition $a$ when the accomplishment of the event will take place in an immediate future time, such as in (38). Until the 20th century these predicative adjective constructions only took que (38a), but from the 20th century onwards, the preposition $a$ began competing with que as the introductory nexus of the subordinate clause (38b). This pattern is somewhat similar to the change of type 2.2 above, because the preposition $a$ again ousted another grammatical particle, but this time it was a conjunction not a preposition.

(38) a. El evento, que se hará en el auditorio del Archivo General de la Nación, está dirigido a autoridades universitarias (El Tiempo, 15 September 1996, Colombia, CREA)

"The meeting, which will take place at the National General

Archive, is addressed for University authorities."

b. Unisys de Venezuela ha organizado para esta tarde a partir de las seis un evento a realizase en el salón Naiguatá del Hotel Tamanaco

(El Universal, 21 April 1993, Venezuela, CREA)

"Unisys from Venezuela has organized for this afternoon a meeting which will take place [lit. an event to take place] at the Tamanaco hotel."

\subsection{Genuine Spanish Creations with the Preposition a 'to' from the Beginning}

Many predicative and non-predicative constructions are genuine Spanish formations, displaying $a$ from the very beginnings of the language. Examples above, such as (3b), me mandó $\boldsymbol{a}$ la mierda 'he sent me to hell'; (6), al comer gastará una gallina 'for lunch [lit. to the eat] he'll spend a poultry'; (7), va a ese pueblo $\boldsymbol{a}$ un pleito 'he goes to that village to a civil action'; (13), niña, ; $\boldsymbol{a}$ callar! 'baby, shut up [lit. to shut up]'; (14), una tortilla a la francesa 'an omelette to the French way'; (15), andan a cangrejos 'seeking crabs [lit. walk to crabs]'; (16), olía mal, a podrido, a cerrado, a miseria 'the air smells bad, closed, rotten, misery [lit. to closed, to rotten, to misery]'; (17), toma veneno a sabiendas 'he takes poison knowingly [lit. to knowingly]', and (23), y ia la chingada! 'fuck you [lit. to the chingada]' are good examples of this fourth type of change.

\subsection{Recodification of Prepositional Constructions via Insertion of the Preposition a 'to'}

Constructions with movement verbs + preposition por 'for' introduced the preposition $a$, forming a prepositional sequence $a$ por 'to for' in co-occurrence with movement verbs, both with directive ones, such as ir 'go' or venir 'come', and with non-directive ones, such as pasar 'pass through' (Company and Flores 2018).

This change took place in Peninsular Spanish only, never in American Spanish, but it is another proof of the invasion of $a$. Example (39a) exhibits the oldest and more generalized construction, (39b) shows the new construction with the insertion of $a$. The last sentences in the two examples of (39), y lo trujeron en unas andas 'and they brought the dead body in a stretcher' in (39a), and $Y$ fueron y llegaron al chozo 'and they went and arrived to the hut' in (39b), confirm the meaning of the accomplished goal which these expressions have.

(39) a. Y que sabiendo los naturales dél de la muerte de dicho cazique, fueron por el cuerpo difunto y lo truxeron en unas andas (Administrative document, 1694, Mexico, CORDIAM)

"the people knowing the cacique's death, went for dead body and brought it on a stretcher."

b. Y dijeron: Pos vamos a por lo nuestro. Y fueron y llegaron al chozo (Marciano Curiel Merchán, Cuentos extremeños, 1944, Spain, CORDE)

"and they said: go for [lit. go to for] our properties, and they went and arrived at the hut." 


\subsection{Insertion of a 'to' in Learned Idioms which Must go with no Preposition}

That is the case of example (22) above: grosso modo > a grosso modo 'broadly speaking [lit. to broad mode]'.

Summing up, the examples and types of changes show a systematic pattern of spreading to new and more varied contexts with four basic mechanisms: (a) the preposition $a$ invaded Latin non-prepositional functions; $(b)$ the preposition appeared ex novo in genuine Romance constructions; $(c)$ the preposition ousted other prepositions in certain constructions, and $(d)$ the preposition joined other prepositions, forming a prepositional sequence or a composed preposition. And summing up again, via this pervasive spreading, the preposition $a$ won eighteen new contexts, as compared to its presence in Latin.

As far as I know, the preposition $a$ only lost one context, exemplified in (40). The compulsory future modal periphrasis with haber 'to have' plus an infinitive took $a$ in Medieval Spanish, as (40a) shows, but from very early times the preposition $d e$ 'of, from' ousted $a$ in this construction, as (40b) shows.

(40) a. toda obra que por mano de omne se aya a fazer (Alfonso X, General estoria. Primera parte, apud Company and Flores 2014)

"every deed of good men which they must have to do."

b. por los serbiçios que nos a fecho en las dichas yslas y esperamos que ha de fazer (Letter, Dominican Republic, 1499, CORDIAM)

"for the services that he has done us in the mentioned islands and we hope he will do [lit. has of do] in the future."

Theoretically, the changes themselves and the six types of pattern listed above are heterogeneous. Some extensions of $a$ involved reanalysis of the preposition when it appears in new contexts, and, as it is well known, reanalysis is the basic mechanism of grammaticalization. ${ }^{6}$ Such are the cases of the encoding of DO and IO functions, because the preposition took on dative and accusative case-marking. In this case, it might be said that it was a case of tradicional grammaticalization because a case-marking is arguably more grammaticalized than a grammatical preposition. Other changes did not involve reanalysis at all, seeming more such as analogical extensions via a metonymic or metaphorical basis: physical space $>$ metaphoric space $>$ time $>$ attitude $>$ quality $>$ result, etc., or also nominal goal $>$ event goal $>$ discourse goal, the preposition preserving its status of a very grammatical preposition. In some other extensions, the preposition is subcategorized by the verb, and there is no choice between $a$ and other preposition, but in other cases, $a$ forms an oblique complement, having certain syntactic freedom. Thus, it might be said that a subcategorized preposition is somewhat more grammaticalized than a preposition heading a non-argumental complement. And yet in some other extensions, the context progress is completely gradual following the expected channel from more favorable contexts $>$ less favorable ones, as it is the case for IO and DO. In other cases, the change seems to be so abrupt, or so sudden, that it is difficult to establish gradual phases, as it is the case of voy por agua > voy a por agua 'I go for some water' > 'I go to for some water', whose first attestation, diffusion and standardization took place in less than one hundred years (Company and Flores 2017).

In sum, from a theoretical point of view, internal heterogeneity is the main feature of the pervasive spreading of $a$ to new contexts, but, with no doubt, there is a salient feature of homogeneity in all changes, which together construe a whole unique pattern: a pervasive spreading to new and different contexts-even, a systematic invasion in many cases-and the creation of new constructions with $a$.

6 Haspelmath (1998) rejects the basicness and need of reanalysis in grammaticalization, although, in my opinion, the author does not demonstrate the point. On the contrary, for Mendivil Giró (2015), reanalysis is the general mechanism of any morphosyntactic change. 


\section{Theory and Data in Dialogue}

In this section I will briefly revise both classical and recent definitions of grammaticalization and related theoretical concepts of language change. I frame the review as a check list, discussing whether or not the spreading of contexts and creation of new constructions without modifying the category status of the form fit with each theoretical definition and framework.

\subsection{Traditional Grammaticalization $\rightarrow$ NO/YES}

The classical definition, in (1) above, of change from a lexical form to a grammatical form or from a grammatical form to a more grammatical one (Hopper and Traugott 2003, p. 2, and many other authors) does not fit with the spreading of $a$ to new and more varied contexts, because this word did not move away from the lexical pole to the grammatical pole, and it was not pressed into service for more grammatical functions.

However, if we look at categories as not internally homogeneous, even the most grammatical ones, as in the case of a grammatical preposition, it would be possible to say that $a$ underwent some kind of grammaticalization in passing from a preposition to a dative and accusative case-marking. Elaborating on the possibility that the preposition would have undergone grammaticalization, it is convenient to consider the following fact: It is not by chance that in formal frameworks, $a$ (along with $d e$ 'of, from') is the grammatical preposition that can most easily govern its term without specifying a thematic role, although in some cases the preposition $a$ can also behave as a true preposition assigning a thematic role. In sum, the formal analysis of the preposition would seem to mean that $a$ is more grammaticalized in Spanish than in Latin.

\subsection{Grammaticalization as "Emergent Grammar" $\rightarrow$ YES}

If "there is no grammar but grammaticalization" (Hopper 1987, 1998), any grammatical change, including analogy, is obviously grammaticalization. Hopper's position is epistemologically very interesting because all changes are a recreation of previous lexical or grammatical material. Nevertheless, definitions such as this are so vague and so broad that they lack any operative specificity to work with.

\subsection{Grammaticalization as "the Emergence of Grammatical Systems" $\rightarrow$ YES}

This definition (Frajzyngier 2010; Hurford 2012, chp. 7) has the same problem as the preceding one: it lacks operative specificity.

\subsection{Grammaticalization as "the Emergence of Language" $\rightarrow$ YES}

This definition (Hurford 2012, chp. 7; Smith 2011, p. 144) has the same problem as the two preceding ones, and is worse because it refers to the evolution of human language and not to the diachrony of specific grammatical systems or specific grammatical items.

\subsection{Secondary Grammaticalization $\rightarrow$ YES/NO}

This subtype of grammaticalization is defined in three ways: (a) "Cases of grammaticalization affecting elements that already have grammatical function and proceed to develop a new grammatical function" (Breban and Kranich 2014); (b) "later stage processes in grammaticalization" (Breban and Kranich 2014), and (c) "The reanalysis of markers of one syntactic category into another one" (Givón 1991). None of these definitions cover the pervasive spreading of a grammatical word to new and more diverse contexts. On the one hand, definitions of secondary grammaticalization do not differ, essentially, from the second section of the definition of traditional grammaticalization: a grammatical form developing more grammatical functions; in that sense, the path preposition > case-marking could also be a secondary grammaticalization. On the other hand, the diachrony of $a$ does not correspond necessarily to "later stage processes in grammaticalization", because many context extensions are very old, and because the spreading is not a case of grammaticalization. Finally, most extensions of the 
preposition $a$, even in cases where they involve new constructions, do not involve reanalysis. Thus, the changes described in Section 2 are incompatible with Givón's definitions (1991).

\subsection{Connecting Grammaticalization $\rightarrow$ YES/NO}

Grammaticalization: chains of grammations, regrammations [transition from one grammatical status to another] and degrammations are seen as one connected process: change A is a precondition for B which again is a precondition for C and D (Nørgård-Sørensen et al. 2011, p. 5).

The pervasive spreading of a grammatical word to new and more diverse contexts is not strictly covered by this definition. However, this definition says that everything in a language system is connected, and in that sense, some contexts of the preposition $a$ are a conditioning step for advancing to a new context. Nevertheless, the changes presented in Section 2 above are not as linear as this definition postulates, because there is a strong overlap in creating new constructions via the progression of $a$ to new contexts (Company and Flores 2014). In addition, this definition lacks explanatory force, in my opinion, because almost any change would be a connecting grammaticalization, following the Saussurean principle of language as "a système où tout se tient" (Saussure 1916).

\subsection{Exaptation $1 \rightarrow \mathrm{NO}$}

Lass (1990) considers exaptation a specific type of language change, not necessarily related to grammaticalization, although this proposal implies reanalysis: "Junk or garbage morphemes acquire a new function". The pervasive spreading of $a$ to new contexts never implied the unemployment of the preposition; that is, a never was a junk particle. All changes happened without previous existence of phonetic or grammatical garbage. Actually, no change undergone by $a$ emerged from prepositional residue.

\subsection{Exaptation $2 \rightarrow$ YES}

"Conceptual invention, [ . . . ] the model itself is what's new" (Lass 1997, 318 ss.). The pervasive spreading of $a$ to new contexts fits in with this second definition of exaptation. It creates a new model of changing, having context as the protagonist and the locus of change. ${ }^{7}$ However, one must be careful, because exaptation seems to be a fairly polysemous concept, losing its descriptive force.

\subsection{Exaptation $3 \rightarrow \mathrm{NO}$}

Morphemes may end up encoding a meaning that is unrelated, or distantly related to what they used to express. Such a functional leap of an existing form can be referred to as linguistic exaptation (Van de Velde and Norde 2016, p. 9).

Every expression with $a$ preserves the basic abstract meaning of 'directive telicity towards a goal'. There never was a functional leap in the diachrony of $a$.

\subsection{Functional Renewal $\rightarrow \mathrm{NO}$}

An old form reappears in the grammar with a new meaning (Brinton and Stein 1995). That was never the case of $a$. This preposition has maintained the same basic abstract meaning for centuries, as described above, winning new distributions and entering to new contexts. The constructional and distributional outcomes of $a$ are, in fact, new, the contexts where the PP- $a$ appears are new also, but the category status of $a$ never changed.

7 Traugott (2004) says that the distinction between exaptation and grammaticalization is false. I am not so sure, I think that the (in)distinction depends, to a large extent, on which definition of grammaticalization is chosen. 


\subsection{Regrammaticalization $\rightarrow$ NO}

The preposition $a$ is not "a desemanticized item found only in a few lexical forms [ . . ] reinterpreted in a new function" (Greenberg 1991). Actually, as I said before, $a$ is probably the most productive preposition in Spanish. It was already very productive in Latin (Baños 2009; Glare 2012, s.v. ad), and it became more productive.

\subsection{Capitalization $\rightarrow$ YES/NO}

The historical process by which a linguistic feature which already exists in a language comes to be substantially exploited for wider purposes (Pountain 1997).

This definition fits in well with the increase of constructions in new contexts of $a$. However, there are two problems with the concept of capitalization. Firstly, it does not imply a pattern of progressive spreading, which is the main trait of the diachrony of $a$. Secondly, Pountain's main example for capitalization, the Spanish auxiliary verb estar 'to be, to stand' that grows at the expense of the verb ser 'to be, to exist', implies category weakening of this last verb, which is not the case with the preposition $a$ nor with the prepositions ousted by $a$. All of them continued to be prepositions in Spanish.

\subsection{Refunctionalization $\rightarrow$ NO}

"A process whereby a form loses its original function and takes on a new function" (Smith 2006). The preposition $a$ never lost its etymological function of introducing a locative complement, and never lost its original relating prepositional function.

\subsection{Adfunctionalization $\rightarrow \mathrm{NO}$}

"A process in which a form assumes a new function alongside or in addition to its original function" (Smith 2006). The preposition $a$ has always been a grammatical preposition, it never changed its category.

Some gaps and some problems are present in the definitions above. First of all, the role of context has been ignored in grammaticalization and in the related frameworks. In consequence, changes consisting in a pervasive spreading of a grammatical form to new contexts without modifying the grammatical status of the form have not been taken into account. Moreover, many definitions overlap with one another and thus lose their explanatory value and descriptive usefulness. For instance, exaptation, secondary grammaticalization, refunctionalization, functional renewal, regrammaticalization, and, in some cases, grammaticalization, are very similar to one another, and similarly, adfunctionalization and capitalization also share many common characteristics. Likewise, some concepts are polysemous, thus losing their descriptive force, although all proposals and types of changes enhance our understanding of language change, with no doubt. In sum, the concept of grammaticalization, which has so powerfully explained many changes and has connected apparently unrelated diachronic processes, "risks to become the victim of its own success", as Breban et al. (2012, p. 2) have noted.

\section{A Theoretical Proposal}

It seems to be necessary to give its own theoretical status to changes such as $a \rightarrow \boldsymbol{a} \rightarrow \boldsymbol{a}$, as it does not readily conform to previously described frameworks. It is not 'traditional grammaticalization'; it only partially conforms to 'capitalization' or 'connecting grammaticalization'; and it fits with 'exaptation', but only in its revised second definition. Obviously, it is 'emergent grammar' and it is characteristic of emergence in grammatical systems, because any language change implies recreation of distribution and recreation of encoding. In a general sense, every language change exists in emergent grammar and in emergent language, as variation, change and malleability are inherent to the everyday language functioning. 
In sum, it is not clear that $a \rightarrow \boldsymbol{a} \rightarrow \boldsymbol{a}$ would be a completely different change from the ones revised in the preceding section. On the one hand, the PP- $a$ shifted to new functions, in a similar way as predicted by most of the definitions above, but it always preserved its category status (except for the reanalysis as a case-marking) and the change was a pervasive extension to new contexts, two facts not considered by the concepts revised in the previous section.

The main difference and the novelty of changes regarding $a$ analyzed in this paper consist, then, in the argument that context, not the form itself, is the protagonist of linguistic change, where context acts in specific distributions and specific constructions. Logically, context goes hand in hand with 'constructionalization', in the sense of 'construction grammar' (Trousdale 2012, pp. 171-72; Traugott and Trousdale 2013, chp. 1), as a lexeme plus morphosyntactic properties plus semantic properties. Syntagmaticity is inherent to human language. This paper adds to the literature by providing a framework for change that can be applied and extended analogically to other contexts.

In sum, the spreading of a form to new contexts with no changes in the category status of the form lacked a term until now. My proposal is that changes such as $\boldsymbol{a} \rightarrow \boldsymbol{a} \rightarrow \boldsymbol{a}$ are 'analogical extensions induced by context', where context is both the unit of change and the locus where the change takes place. The analogical model is not a proportional equation, as traditional analogy is, but an extension motivated by the preceding context and by the stability of the general basic abstract meaning of linguistic forms. Certain contexts emerge because they are motivated or induced by other syntactically and semantically close contexts. The change thus can be described as context addition.

Other changes in Spanish involving grammatical words, such as clitics and particles, follow the same diachronic pattern. That is the case of $l e$ 'him' 'her', se '-self', or of some prepositions, but to a lesser extent than the preposition $a$. They continue to have the same category and the same form, and only new contexts appear (Company 2006; Company and Sobrevilla 2014).

My proposal is also that, in many cases, it is necessary to leave the word level in diachrony and consider context as the unit of change. The type of change analyzed here must be included both in general grammatical change and in constructionalization. It would be labeled as 'context construction', a type of construction not listed in the inventory of Hoffman \& Trousdale in their handbook on Construction grammar (Hoffmann and Trousdale 2013, p. 2).

\section{Conclusions}

This paper has shown five theoretical points: first, that, under certain conditions, context is the unit of language change, when some grammatical words are at work. Context, in addition, is always the locus of change. Second, that certain changes consist in a very active spreading of a form to new contexts, without changing the category status of that form. Third, that in certain cases of language change, it is necessary to leave the word level. Fourth, that the spreading to new contexts is an analogical extension. Finally, that this type of change may be termed as spreading of context, a type of construction not included in 'construction grammar' nor in 'constructionalization' works.

The paper has also shown that spreading of context is not grammaticalization, demonstrating that grammaticalization has neglected the essential role of context in language change, at least in changes involving various grammatical words.

The empirical evidence to make the five proposals above has been the history of the Spanish preposition $a$, characterized by a very active diachrony, but, at the same time, by a high stability, both in category status and in meaning.

Finally, we have linked theory and diachronic data reviewing fourteen theoretical concepts related to grammaticalization, and checking them against the diachronic evidence of the preposition $a$.

Funding: This research received no external funding.

Conflicts of Interest: The author declares no conflict of interest. 


\section{References}

Alcina, Juan, and José M. Blecua. 1975. Gramática española. Barcelona: Ariel.

Allen, Joseph H., and James B. Greenough. 1979. New Latin Grammar for Schools and Colleges: Founded on Comparative Grammar. New Rochelle: Caratzas Bros.

Baños, José Miguel. 2009. Dativo. In Sintaxis del latín clásico. Edited by J. M. Baños Baños. Madrid: Liceus, pp. 185-208.

Breban, Tine, and Svenja Kranich. 2014. Secondary grammaticalization and other later stage processes in grammaticalization. Paper presented at the Workshop Secondary Grammaticalization, 21st International Conference on Historical Linguistics, Oslo, Norway, August 5.

Breban, Tine, Jerven Vanderbiesen, Kristin Davidse, Liesolette Brems, and Tanja Mortelmans. 2012. Introduction. New reflections on the sources, outcomes, defining features and motivations of grammaticalization. In Grammaticalization and Language Change. New Reflections. Edited by Kristin Davidse, Tine Breban, Jerven Vanderbiesen, Liesolette Brems and Tanja Mortelmans. Amsterdam and Philadelphia: John Benjamins, pp. 1-35.

Brinton, Laurel, and Dieter Stein. 1995. Functional renewal. In Historical Linguistics 1993. Selected Papers from the 11th International Conference on Historical Linguistics. Edited by Hennig Andersen. Amsterdam and Philadelphia: John Benjamins, pp. 33-47.

Bybee, Joan L., Revere Perkins, and William Pagliuca. 1994. The Evolution of Grammar. Tense, Aspect, and Modality in the Languages of the World. Chicago: The University of Chicago Press.

Company, Concepción. 2003. La gramaticalización en la historia del español. In Gramaticalización y cambio sintáctico en la historia del español. Edited by Concepción Company. México: Universidad Nacional Autónoma de México, pp. 1-62.

Company, Concepción. 2006. El objeto indirecto. In Sintaxis histórica de la lengua española. Primera parte: La frase verbal. Edited by Concepción Company. México: Fondo de Cultura Económica \& Universidad Nacional Autónoma de México, vol. 1, pp. 479-574.

Company, Concepción, and Rodrigo Flores Dávila. 2014. La preposición a. In Sintaxis histórica de la lengua española. Tercera parte: Adverbios, preposiciones y conjunciones. Relaciones interoracionales. Edited by Concepción Company. México: Fondo de Cultura Económica \& Universidad Nacional Autónoma de México, vol. 2, pp. 1195-340.

Company, Concepción, and Rodrigo Flores Dávila. 2017. Género textual, diacronía y valoración de un cambio sintáctico. A por con verbos de movimiento. Boletín de la Real Academia Española 79: 203-39.

Company, Concepción, and Rodrigo Flores Dávila. 2018. El contraste a por vs. por con verbos de movimiento. Gramática y diacronía. Revista de Filología Española 98: 281-318. [CrossRef]

Company, Concepción, and Zazil Sobrevilla Moreno. 2014. Las preposiciones de, des y desde. In Sintaxis histórica de la lengua española. Tercera parte: Adverbios, preposiciones y conjunciones. Relaciones interoracionales. Edited by Concepción Company. México: Fondo de Cultura Económica \& Universidad Nacional Autónoma de México, vol. 3, pp. 1341-477.

Diewald, Gabriele. 2002. A model for relevant types of contexts in grammaticalization. In New Reflections on Grammaticalization. Edited by Ilse Wisher and Gabriele Diewald. Amsterdam: John Benjamins, pp. 103-20.

Frajzyngier, Zygmunt. 2010. Grammaticalization within and outside of a domain. In Formal Evidence in Grammaticalization Research. Edited by An Van Linden, Jean-Cristophe Verstraete and Kristin Davidse. Amsterdam and Philadelphia: John Benjamins, pp. 43-62.

Geurts, Bart. 2000. Explaining grammaticalization (the standard way). Linguistics 38: 781-88. [CrossRef]

Givón, Talmy. 1991. The evolution of dependent clause morpho-syntax in Biblical Hebrew. In Approaches to Grammaticalization, vol. II: Types of Grammatical Markers. Edited by Elizabeth Closs Traugott and Bernd Heine. Amsterdam and Philadelphia: John Benjamins, pp. 257-310.

Glare, Peter G. W. 2012. Oxford Latin Dictionary. Oxford: Oxford University Press.

Greenberg, Joseph H. 1991. The last stages of grammatical elements: Contrative an expansive desemanticization. In Approaches to Grammaticalization. Volume I: Theoretical and Methodological Issues.. Edited by Elizabeth Closs Traugott and Bernd Heine. Amsterdam and Philadelphia: John Benjamins, pp. 301-14.

Haspelmath, Martin. 1998. Does grammaticalization need reanalysis? Studies in Language 22: 315-51. [CrossRef]

Heine, Bernd. 2002. On the role of context in grammaticalization. In New reflections on grammaticalization. Edited by Ilse Wisher and Gabriele Diewald. Amsterdam: John Benjamins, pp. 83-101. 
Heine, Bernd. 2003. On degrammaticalization. In Historical Linguistics 2001. Edited by Barry J. Blake and

Kate Burridge. Amsterdam \& Philadelphia: John Benjamins, pp. 163-80.

Heine, Bernd, and Mechthild Reh. 1984. Grammaticalization and Reanalysis in African Languages. Hamburg: Helmut Buske.

Heine, Bernd, Ulrike Claudi, and Friedericke Hünnemeyer. 1991. Grammaticalization. A Conceptual Framework. Chicago: The University of Chicago Press.

Hoffmann, Thomas, and Graeme Trousdale. 2013. Construction grammar. Introduction. In The Oxford Handbook of Construction Grammar. Edited by Thomas Hoffman and Graeme Trousdale. Oxford: Oxford University Press, pp. 1-14.

Hopper, Paul. 1987. Emergent grammar. Berkeley Linguistics Conference 13: 139-57. [CrossRef]

Hopper, Paul. 1991. On some principles on grammaticization. In Approaches to Grammaticalization. Edited by Elizabeth Closs Traugott and Bernd Heine. Amsterdam: John Benjamins, pp. 17-36.

Hopper, Paul. 1998. Emergent grammar. In The New Psychology of Language. Cognitive and Functional Approaches to Language Structure. Edited by Michael Tomasello. New Jersey: LEA, pp. 155-75.

Hopper, Paul J., and Elizabeth Closs Traugott. 2003. Grammaticalization. Cambridge: Cambridge University Press. Hurford, James R. 2012. The Origins of Grammar. Oxford: Oxford University Press.

Kuryłowicz, Jerzy. 1975. The evolution of grammatical categories. In Esquisses linguisique II. Munich: Wilhelm Fink. First published 1965.

Lass, Roger. 1990. How to do things with junk: Exaptation in language evolution. Journal of Linguistics 26: 79-102. [CrossRef]

Lass, Roger. 1997. Historical Linguistics and Language Change. Cambridge: Cambridge University Press.

Lehmann, Christian. 1995. Thoughts on Grammaticalization. Munich: LINCOM. First published 1982.

Meillet, Antoine. 1965. L'evolution des formes grammaticales. In Linguistique historique et linguistique générale. Paris: Edouard Champion, vol. 1, pp. 130-49. First published 1912.

Mendívil Giró, José Luis. 2015. El cambio lingüístico. Sus causas, mecanismos y consecuencias. Madrid: Síntesis.

Nørgård-Sørensen, Jens, Lars Heltoft, and Lene Schøsler. 2011. Connecting Grammaticalisation. Amsterdam and Philadelphia: John Benjamins.

Pountain, Christopher J. 1997. Capitalization. In Historical Linguistics 1995, vol. I: General issues and non-Germanic Languages. Edited by John Charles Smith and Delia Bentley. Amsterdam and Philadelphia: John Benjamins, pp. 295-309.

Rougiest, Eugeen. 1980. Les prepositions "a" et "de" en espagnol contemporain. Gent: Rejksuniversiteit Gent.

Saussure, Ferdinand de. 1916. Cours de Linguistique Générale. Paris: Payot.

Smith, John C. 2006. How to do things without junk. The refunctionalization of a pronominal subsystem between Latin and Romance. In New Perspectives on Romance Linguistics, vol. II: Phonetics, Phonology and Dialectology. Edited by Chiyo Nishida and Jean-Pierre Montreuil. Amsterdam and Philadelphia: John Benjamins, pp. 183-205.

Smith, Andrew D. M. 2011. Grammaticalization and language evolution. In The Oxford Handbook of Grammaticalization. Edited by Heiko Narrog and Bernd Heine. New York: Oxford, pp. 142-52.

Traugott, Elizabeth Closs. 2001. Legitimate counterexamples to unidirectionality. Paper presented at Freiburg University. October 17. Available online: www.stanford.edu/traugott (accessed on 1 February).

Traugott, Elizabeth Closs. 2004. Exaptation and grammaticalization. In Linguistic Studies Based on Corpora. Edited by Minoji Akimoto. Tokyo: Hitsuji Shobo, pp. 133-52.

Traugott, Elizabeth Closs, and Graeme Trousdale. 2013. Constructionalization and Constructional Changes. Oxford: Oxford University Press.

Trousdale, Graeme. 2012. Grammaticalization, constructions and the grammaticalization of constructions. In Grammaticalization and Language Change. Edited by Kristin Davidse, Tine Breban, Lieselotte Brems and Tanja Mortelmans. Amsterdam \& Philadelphia: John Benjamins, pp. 167-98.

Tullio, Ángela di. 1997. Manual de gramática del español. Desarrollos teóricos, ejercicios, soluciones. Buenos Aires: Edicial. Van de Velde, Freek, and Muriel Norde. 2016. Exaptation. Taking stock of a controversial notion in linguistics. In Exaptation and Language Change. Edited by Muriel Norde and Freek van de Velde. Amsterdam and Philadelphia: John Benjamins, pp. 1-35.

(C) 2019 by the author. Licensee MDPI, Basel, Switzerland. This article is an open access article distributed under the terms and conditions of the Creative Commons Attribution (CC BY) license (http:/ / creativecommons.org/licenses/by/4.0/). 
Article

\title{
On the Latin Origins of Spanish mediante
}

\author{
Esther Artigas \\ Departament de Filologia Clàssica, Romànica i Semítica, Universitat de Barcelona, 08007 Barcelona, Spain; \\ eartigas@ub.edu
}

Received: 4 February 2019; Accepted: 20 February 2019; Published: 28 February 2019

\begin{abstract}
This paper aims to contribute to the clarification of the linguistic and extra-linguistic circumstances that accompany the emergence and behavior of mediante in the first centuries of Spanish. To this end, the origin of the Latin participle medians, mediantis is examined and the evidence of its ablative form mediante in various contexts is also analysed and discussed. We conclude from our study that (1) the appearance of mediante in Latin takes place at a relatively late stage of Latin, it having entered the language as a grammatical calque from Greek; (2) in Latin, prepositional values of mediante, which do not necessarily originate from Latin absolute ablative clauses, are already detected; and finally, (3) discursive traditions and historical-cultural factors, in particular those developed in Patristic and Scholastic Literature, are fundamental for the understanding, not only of the evolution of mediante in Latin, but also of its introduccion into Spanish.
\end{abstract}

Keywords: Latin mediante; grammatical calque; participle clause; prepositional value; discursive tradition

\section{Introduction}

There is no dispute that mediante - a so-called improper, or imperfect, Spanish preposition-is derived from the Latin present participle medians, -ntis in absolute constructions. As it entered Spanish, it must have undergone a process of grammaticalization that led to the transcategorization from participle to preposition. ${ }^{1}$

Beyond these claims, the Latin origins of mediante have not been well defined, nor has their development in this language been sufficiently described and explained. This suggests not only a gap in the history of Latin which deserves consideration, but also deprives us of relevant data and the arguments necessary to explain the particular process of the incorporation of mediante into Spanish.

In this paper, therefore, we propose not so much a detailed history of mediante in Latin on the basis of an analysis and discussion of Latin examples and usage, but a contribution to the clarification of the linguistic and extra-linguistic circumstances that accompany the emergence and behavior of mediante in the first centuries of Spanish.

To be clear, we aim to show that on the one hand, mediare is not a truly Latin verb. It appeared in Late Latin, having entered the language via a grammatical calque from Greek, specifically from the Bible. Nor does it seem that we should rule out the change represented by the calque in favor of one which involves a process of grammaticalization (cf. Garachana in this volume).

On the other hand, analyzing the meanings of mediante in its first appearances in Latin texts produces interesting and useful results which may be compared with those in the first centuries of Spanish: temporal value, when nouns denoting time are selected, and instrumental value and usages which derive from the instrumental in the remaining cases. At this point, the absolute character of the constructions in which mediante appears should be discussed, since, as is well known, a participle in

1 The statement is commonplace in all Spanish grammars; see Sánchez López (2014). On the grammaticalization process, see, among others, Sánchez Lancis (2001-2002) and Castro Zapata (2012). 
the ablative is not synonymous with an ablative absolute. We will see that the evolution of mediante in the direction of prepositional values does not originate in Latin absolute ablatives, but in other participial constructions, with a greater degree of integration in predication. ${ }^{2}$

Thirdly, we will show that already in Latin there are signs of the prepositional values of mediante, the consolidation of which, nevertheless, are indissociable from the growth of this form within Scholasticism. This finding should also serve as a basis with which to reexamine the explanation of the process of change by grammaticalization that is suggested for Spanish.

Finally, this paper aims to stress the importance of discursive traditions and historical-cultural factors in the evolution of linguistic units. The trajectory of Latin mediante allows us to distinguish two key moments on which we will focus: its appearance in the Patristic Period (between the 2nd century $\mathrm{AD}$ and the year 753), and the period represented by Scholasticism, (especially High Scholasticism, of the 13th and 14th centuries). By way of the Church Fathers, mediante entered Latin through a grammatical calque through contact with Greek. But the extension of mediante no doubt corresponds to the Scholastic period, when the syntactic reanalysis of this form occurred, as well as its establishment as a grammatical instrument for, among other things, the expression of cause. The repeated and intentional use of mediante in Scholasticism reveals once again the close link between linguistic change and discursive traditions (cf. Company 2008; Kabatek 2005; Llopis Cardona 2015). Thus, it seems appropriate for the explanation of the grammatical change not to limit oneself to strictly linguistic explanations, but to take into account historical and socio-cultural factors.

The singular history of mediante in Latin, from its appearance in Late Latin to its emergence within a very specific discursive tradition, has led us to organize this work chronologically and to center it in the periods and domains already mentioned. In part one (Section 2), we will document the late origins of the verb mediare and track its route into Latin. Then, in part two (Section 3), we will deal with its use and meaning across the Patristic Period. Part three (Section 4) is dedicated to the development and extension undergone by mediante in the High Scholastic period, especially the appearance of clear prepositional meanings. Finally, part four (Section 5) contains the author's conclusions.

\section{Late Origins: First Evidence of mediare}

An initial important point in the history of mediante is that the Latin verb mediare, to which the present participle medians, mediantis must be related, is not documented in the Latin of the ancient period; that is, neither in the Early nor in the Classical or Postclassical periods of the history of the language. In fact, the first examples we have are from Late Latin ${ }^{3}$.

A starting point in the trajectory of this verb is a passage from the Vetus version of the Bible which, as is well known, is the first Latin translation of the biblical text, which began on African soil not before the second half of the second century AD. The passage is from the Gospel of John (7:14), where it relates that Jesus, on his way through the lands of Galilee, went secretly to the Jewish Feast of Tabernacles; see example (1).

(1) Iam die festo mediante ascendit Iesus in templum et docebat

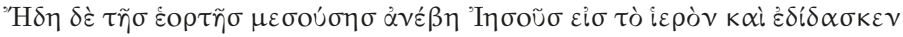

"Then in the middle of the feast Jesus went up to the temple and began to teach"

With the extreme formalism that characterizes the Vetus Latina, the text translates the corresponding Greek passage of the Septuagint entirely literally. It is not only a lexical calque, but also a strict parallelism of the syntactic structure. In both cases, the statement is headed by an equivalent participle

2 Kortmann (1992, pp. 436-37) already showed that unrelated free adjuncts or dangling participles are also an important source of departicipial prepositions.

3 Latin examples adduced in this paper are extracted and quoted according to the corpus of Brepolis (CDL (n.d.): Cross Database Searchtool, Brepolis Library of Latin Texts Series A-B, Turnhout, Brepols) and the THLL (1900-present): Thesaurus Linguae Latinae, Teubner, Stuttgart \& Leipzig. 


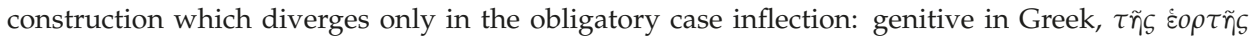
$\mu \varepsilon \sigma o u ́ \sigma \eta \zeta$, and ablative in Latin, die festo mediante. ${ }^{4}$

A second piece of evidence, more or less immediate in chronology, is that of Irenaeus (ca. 130-202 AD), bishop of Lyon. The original Greek of his treatise Against Heresies has come to us in very fragmentary form, but we still have the Latin translation that followed the appearance of the Greek version. In it can be found the passage in example (2):

(2) Omnes autem hi, multo posterius, mediantibus iam ecclesiae temporibus, insurrexerunt in suam apostasiam (Irenaeus Lugdunensis, Aduersus haereses 3, 4, 3)

"All these, much later, in the middle ages of the Church, rose up in their apostasy"

The example, like the previous one, includes an incidental participial construction with the peculiarity that the agreement of the participle and its subject is made in the plural. Since its function is to explain multo posterius, it is clear that the value inferred is temporal: long after the institution of the church, having already exceeded half of its trajectory, in an already advanced stage.

This late appearance of mediare at the beginning of the Patristic Period, as well as its later diffusion in the same area, leads us to conclude that the verb mediare must have been introduced into Latin as a neologism from Greek as a lexical calque. It is true that in Latin, the existence of an adjective medius, of the corresponding adverb medie and even of the abstract medietas, could make the incorporation of this verb as a denominative not totally alien, but we can still assume that there may have been some difficulties of integration. On the one hand, as we shall see, the evidence at our disposal for the period between $200 \mathrm{AD}$ and 753 is scarce. And to this we may perhaps add some indications of what might be considered problems of inadequacy. For example, in the passage Hebrews (6:17), where God is said to guarantee by oath the fulfillment of his purposes, the Vulgate version of St. Jerome regularized and corrected the predicate mediavit iurationem to interposuit iurisiurandum-quite clear, but less truly

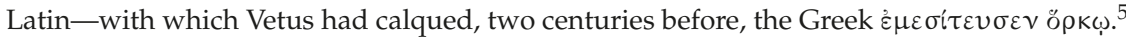

If we are right in thinking that we are dealing with the incorporation of a lexical item through a calque which was somewhat favored in Latin by the existence of closely related forms, it is not improbable also to attribute to that particular way of entry the predominant use of mediare in its participial form, which was fixed in the ablative as a faithful transfer, as we have seen in (1), of the corresponding genitive in Greek. ${ }^{6}$ In other words, Latin, also protected by a very specific discursive tradition, would have derived from Greek not only the lexical item, but also the type of construction in which it is most often represented.

\section{The Long Patristic Period}

A brief search in the Brepols corpus for the Patristic Period allows us to verify that the forms of the present participle of mediare are much more frequent than the finite forms of this same verb or those corresponding to the perfect participle. Likewise, we can observe the preponderance of the singular ablative mediante, followed at a considerable distance by the plural ablative mediantibus in greater numbers than other grammatical cases; see Table 1.

4 Throughout this paper, we argue that in Latin, these structures constitute not so much absolute ablatives as locative ablatives of temporal location. This is not a problem for the translation of the Greek construction, especially because this language also allows the use of the genitive for the expression of time, as well. See Crespo et al. (2003, pp. 138-39).

5 We find a quite similar situation in the psalter of Monte Cassino, 54, 24: viri sanouinum et fraudis non mediabunt (Gr. $\dot{n} \mu \iota \varepsilon \dot{\sigma} \sigma \omega \sigma \iota v)$ dies suos "men [guilty] of bloods and deceit will not reach half their days." The Vulgate version corrects mediabunt to dimidiabunt.

6 Regarding the comparison and behavior of absolute constructions, cf. Coleman (1989, p. 364). Reproduction of Greek patterns in late Latin can be explored in Moreno Hernández (1996, p. 472). 
Table 1. Occurrences of mediare in the Patristic Period.

\begin{tabular}{ccc}
\hline Forms of mediare & \# of Occurrences & Frequency per Million Words \\
\hline Present participle in sg. ablative (mediante) & 52 & 1.70 \\
Present participle in pl. ablative (mediantibus) & 4 & 0.13 \\
Present participle, sg. and pl., in other cases & 2 & 0.06 \\
Perfect participle (mediatus, $-a,-u m$ ) & 14 & 0.45 \\
Finite forms & 7 & 0.22 \\
\hline
\end{tabular}

On the other hand, the data suggest that as mediante emerged, we have a fairly fixed construction in Latin and, moreover, one linked to a language with a markedly biblical and hermeneutic character, which had developed in response to pragmatic discursive needs within a particular discursive tradition.?

\subsection{Senses and Meanings}

For analysis of the conditions that triggered the prepositional value of mediante, in all likelihood in Latin itself, it is fundamental to note the meanings with which the verb mediare was incorporated from Greek into Latin.

As recorded in the corresponding entry in Thesaurus Linguae Latinae, the examples that attest to the use of mediare in Latin show that this verb corresponds to at least two Greek verbs: $\mu \varepsilon \sigma o ́ \omega$ and $(\dot{\varepsilon}) \mu \varepsilon \sigma \iota \tau \dot{\varepsilon} v \omega{ }^{8}$ The first is based on the adjective $\mu \varepsilon \dot{\varepsilon} \sigma 0 \sigma$ "midway between" and means "in the midst of." The second, on the other hand, is based on the agentive noun $\mu \varepsilon \sigma i \tau \eta \sigma$ "intermediary, mediator" (a noun which Latin imported in the form of mediator at the same time as the verb mediare) and which means, consequently, "to be in the middle, mediate, interpose" and, by extension, "intercede" and even "guarantee". Thus, in Latin, two basic meanings are distinguished for mediare: one, exemplified in example (3), corresponds to the value of "being in the middle" and selects, as in Greek with the verb $\mu \varepsilon \sigma o ́ \omega$, nouns that designate units or periods of time and events associated with such units or periods. The second value, which we find in example (4), translates Greek $\mu \varepsilon \sigma \iota \tau \varepsilon v \omega$ and draws on the sense of "being in the middle, to mediate". Unlike the first, it presents practically no restrictions in the selection of its subject.

(3) Pisces scorpiones rapulatos. Coquis in liquamen et oleo et cum mediaverit coctura, tolles. (Apicius, Breuis ciborum 7, 89, 21)

"Scorpion fish with turnips. You cook the scorpions in garum and oil, and halfway through the cooking, you take them out."

(4) haec enim deitas inhabitans operabatur, haec inhabitans mediabat utrique eorum (Collectio Avellana: Epistulae 263, 1)

"For this divine nature worked by dwelling within; dwelling within, it mediated between both thing (the soul and body of Christ)"

\subsubsection{The Expression of Time}

As for the occurrences of this verb in the participial form mediante, which is the most common and the one that interests us the most, we see an identical distribution of values. In the first place, the form mediante participates, in participial constructions that select as subjects temporal nouns or nominalized events associated with temporal units, as can be seen in examples (5)-(7).

7 For the concept of discursive tradition and the relevance of discursive traditions in the emergence and expansion of linguistic change, cf. Kabatek (2005). A good review of the issue is in Llopis Cardona (2015), particularly interesting in our case because, differences notwithstanding, the analysis of in hoc sensu runs along a route which is, in many respects, similar to that of mediante, highlighting the importance of Scholasticism in the emergence and consolidation of this grammatical particle.

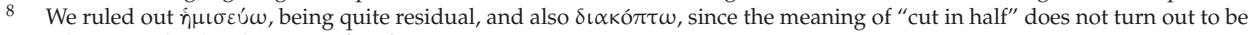
relevant in the development of mediare in Latin. 
(5) inoculari ficus locis siccis Aprili, umidis Iulio mediante poterit, Octobri mense locis tepidis (Palladius Rutilius Taurus Aemilianus, Opus agriculturae 4, 10, 32)

"The fig tree can be grafted in April in dry places, in mid-July in humid (places), in the month of October in temperate (places)"

(6) et agatur nona temperius mediante octaua hora, et iterum quod faciendum est operentur usque ad uesperam (Benedictus de Nursia, Regula 48, 6)

"The None must be done earlier, at half past eight/in the middle of the eighth hour, and then go back to work on what has to be done by vespers"

(7) Iam enim mediante epulo rex locutus est sacerdotibus qui aderant (Gregorius Turonensis, Historiarum libri $X, 8,1$ )

"So, halfway through the banquet, the king spoke to the priests who were present"

It is, however, a rather minor use. Of the 52 examples of mediante obtained in this period, only on 11 occasions is a subject expressing time selected, of which, in addition, six correspond to evidence derived or related to the biblical text die festo mediante, which we have illustrated in (1). For its part, the ablative plural form mediantibus, documented on a total of four occasions, only appears with a temporal noun in the example previously cited in (2).

However, additionally, instances of the temporal value are also scarce in the later development of the prepositional value. Perhaps we can already anticipate some reasons for this.

In this type of syntagm, the temporal noun with which mediante agrees is encoded by an ablative of temporal location or 'time at or during which'. The syntagm functions as an adjunct located on the periphery of the sentence, whose degree of integration with respect to the nuclear predication is uneven. Thus, in example (5), we have in Iulio mediante an ablative of temporal location which is fully comparable to the temporal complements Aprili and Octobri mense in the same sentence, which, syntactically, function as adjuncts subcategorized by inoculari "graft". In contrast, in (1) and (7) the scope of the ablative syntagma, as a free constituent, is extended to encompass the entire sentence. In fact, in (1) and (7) mediante is inserted on a distinct syntactic level, since it is not a complement of the verbal predicate directly, but of the whole of the predication for which it provides temporal coordinates. It is no coincidence that the temporal ablative appears at the beginning of the sentence, as is often the case in Latin with the expression of the concomitant circumstances (for example, in absolute ablative clauses or in subordinates of the historical cum sentences). In our opinion, the possibility of left-dislocation of these temporal complements may well have slowed down the evolution of mediante toward prepositional uses, as the syntactic level on which it is situated does not favor the creation of the points of integration which are necessary for such meanings to surface.

With specific regard to the participle, we should note that, with nouns denoting time, it is lexicalized as an adjective, functioning at the level of the noun phrase, not the level of the sentence. As an adjective, it indicates that the noun has the characteristic of "being in the middle" of the space that the noun represents. In this sense, the behavior of mediante is totally comparable in Latin to that of the adjective medius, an adjective which, as we have pointed out above, would have already formally favored the entry of the participle into the Latin language. Recall that the adjective medius, along with other locative adjectives (imus, summus, ultimus, etc.), can refer in Latin to the noun in its entirety or affect only a part of it. Thus, medius mons can mean "the middle mountain" or, with the partitive meaning, "the mountain in its middle," that is, "the middle of the mountain". This second sense of medius, which is partitive in nature, is shared with the meaning mediante has as an adjective of temporal location. We can exemplify what we are saying with these two passages of Gregory of Tours, see (8) and (9), where medio and mediante refer to half of the month to which they modify:

(8) Nam medio mense XI. adveniens, ( . . ) Pelagium papam perculit et sine mora extinxit. (Gregorius Turonensis, Historiarum libri X, 10, 1)

"And when the middle of the eleventh month came, ... he struck Pope Pelagius and killed him without delay" 
(9) Sol eclypsin pertulit mense VIII. mediante (Gregorius Turonensis, Historiarum libri X, 10, 23) "The sun suffered an eclipse in the middle the eighth month"

Finally, the fact that mediante does not develop verbal functions and behaves as a mere adjective prevents the noun with which it combines from having an active value. Therefore, in this type of clause, the syntactic and semantic behavior of mediante is equivalent to that of the mediopassive participle mediato. This is also related to the fact that in Late Latin, the present participle served to express not only a temporal relation of simultaneity, but also of an anteriority which in our examples (1) and (7) is marked, additionally, by the adverb iam. ${ }^{9}$ In addition to the translation into Latin of the Greek aorist participle, this possibility compensated for the deficiency in Latin of an active perfect participle. ${ }^{10}$

To exemplify this, it is very significant how St. Augustine gathers and glosses, in three almost consecutive paragraphs of his Treatises on the Gospel of St. John, the sequence die festo mediante in our example (1), in order to clarify that the feast does not refer to a single celebration but to a succession of them, namely eight: ${ }^{11}$

(10) a. docebunt sic eum adscendisse mediato die festo, id est mediatis illis diebus (Augustinus Hipponensis, In Iohannis euangelium tractatus 28, 8)

"So shall they teach that he went up in the midst of the feast, that is, in the midst of those days" b. adscendit autem postea, ut euangelium loquitur: mediato die festo, id est, cum iam illius diei festi tot dies praeteriissent quot remansissent (Augustinus Hipponensis, In Iohannis euangelium tractatus 28, 10)

"Then he went up, as the gospel explains, mid-feast, that is, when the feast had gone for as many days as still remained"

c. adscendit ergo postea dominus ad diem festum, mediante die festo, et docebat (Augustinus Hipponensis, In Iohannis euangelium tractatus 29, 1)

"Then the Lord went up to the feast days, in the middle of the feast days, and began to teach"

\subsubsection{From Instrument to Means, Mediation, Agent and Cause}

The second sense which we have noted for mediante, namely that of interposition, which was brought into Latin from the Greek $\mu \varepsilon \sigma \iota \tau \varepsilon$ vw 'to be in the middle, to mediate, to interpose', can be documented somewhat more widely throughout the Patristic Period, and also has a greater influence in the development of prepositional uses. The most general sense we get from the examples considered is, as we say, that of mere "interposition", that is, the "situation in the middle" of the noun agreeing with mediante, which can be both inanimate (tangible or intangible) or animate (generally human).

(11) In inferiore uero parte urbis, ubi templum in uicinia muri ab oriente locatum ipsique urbi transitu peruio ponte mediante fuerat coniunctum (Beda Venerabilis, De locis sanctis 2, 53)

"In the lower part of the city, where the temple had been placed in the vicinity of the wall to the east and had been attached to the city itself with an accessible passage, with a bridge that was in the middle/by means of a bridge"

(12) Non mirandum est, si uel de deo uel de homine probe non sentiant, qui utrumque a se odio mediante longinquant (Claudianus Mamertus, De statu animae 1, 1)

"It is not surprising if those who distance themselves from one another as a result of the hatred between them/because of hatred, do not think well either of God or of man"

9 For the usage of iam as method for positioning a time interval on the timeline of the speaker, cf. Torrego (2010, pp. 14-15).

10 Cf. Lorenzo (1998, pp. 43-44). Moreover, Coleman (1989, p. 371, n. 29) recalls that with deponent verbs, postclassical Latin often used the present participle (ingrediens) where a perfect active participle (ingressus) was available. In this regard, and with respect to mediare, it is worth recalling that the grammarian Charisius cites, in an exhaustive list of deponent verbs, a verb medior whose meaning is explained as in medio esse (Flauius Sosipater Charisius, Artis grammaticae libri V p. 479, 1. 22).

11 Anselmus Laudunensis, Glosae super Iohannem 7, 14: iam die festo mediante (quia per octonos dies agebatur hæc solempnitas) ascendit Iesus in templum et docebat. 
(13) Unde mediante uiro inlustri Lupone duce per iussionem supra fati gloriosi principis Childerici haec omnia, que superius abentur inserta, in omnibus conseruari conuenit. (Concilia Galliae 511-695: Concilium Modogarnomense a. 662-675, SL 148A, p. 313)

"Thus, by means/throught the offices of the illustrious Duke Lupo by order of the glorious prince Childeric above mentioned, it is agreed to observe completely all these things stated above"

Although it may be thought that formally we are dealing with absolute participial clauses, consideration of these examples soon reveals the limited independence of constructions from the main phrase in which they are inserted. ${ }^{12}$ It becomes clear that in (11) and (12), the nouns ponte and odio, on which the quality mediante is predicated, appear closely linked to the predicates "be attached" and "distance themselves" from their respective sentences, in respect of which they act as sociative-instrumental ablatives, as is typical of the argument structure of verbs that express notions of union or conciliation and their opposites. Thus, unlike the temporal values to which we have just referred, where the possible dislocation of the construction makes it more easily identifiable, here the connection established by the sociative-instrumental ablative (and its derived uses, especially the causal) with the predicate of the sentence undoubtedly constitutes a factor which favors the interpretation of mediante as a preposition:

to attach with a bridge in the middle $\rightarrow$ to attach by means of a bridge

(Material value, of means, with tangible things)

distance by the hatred interposed $\rightarrow$ distance because of hatred

(Figurative value, of cause, with abstract concepts)

The scope of mediante in these constructions is reduced to a noun: pons in (11), odium in (12) and uir in (13). That is to say, mediante in these cases is a constituent of the sentence; hence, it can express various semantic relationships between the construction in which it is inserted and the main sentence, and functions similarly to a preposition. Apart from the meaning, different syntactic behavior marks the difference between the temporal mediante and the mediante of means, since the former does not require the same integration in the sentence as the latter. When we say, returning to example (5), in mid-July, that is to say, when July is halfway through, the references we use to establish this notion of half do not exceed the limits of the temporal noun: we are speaking of half of the space between the 1st and 31st of July. Therefore, mediante or "in the middle" is related only to the temporal noun and not to the syntactic context of the sentence of which it is part. In a very different way, in (11), with ponte mediante, we are not referring to the middle of the bridge, but indicating that its position is more or less equidistant between the external references to it: the temple and the city, so that mediante or "in the middle of" establishes a syntactic and also semantic relationship with the predicate of the sentence, just as a prepositional phrase would do.

Again, the behavior of mediante with instrumental ablatives refers to the use of the adjective medius, this time when it affects the noun in its entirety: medius mons does not mean in these cases "the middle of the mountain" but "the mountain in the middle." In fact, it is a question not so much of a different meaning of the adjective as a of different designation of the noun: the concept "mountain" is here designated as a class of entities and the adjective medius selects the one having the "middle" quality (Tarriño Ruiz 2009, p. 267).

Deserving of separate consideration are the cases in which mediante appears with a noun that refers to people and also to human qualities or attributes. These are usually in a hybrid context in which mediante allows for a reading with the basic meaning of "being in the middle", as well as a reading that implies the extension of that sense to the notion of "intervention or intercession". This

12 We cannot ignore the difficulty, which has been abundantly demonstrated, in drawing precise boundaries between the constructions known as absolutes and those participles in concordance with distinct types of the ablative, especially those of concomitant circumstances. Cf., for example, Serbat (1979, pp. 353-54). 
depends, in fact, on the noun which refers to the animated entity being seen either simply as the vehicle through which the predicate of the sentence acts or as the effective agent of mediation.

In the first of these possibilities, we are dealing with constructions whose syntactic and semantic characteristics are identical to those indicated above for examples (11) and (12). Thus, in the example (13), even though we have an animated feature [+ human], Duke Lupo's agentive ability is not verified, since it is not his function to observe the things prescribed by Childerico but to serve as a channel or vehicle for them to be observed. Likewise, in (14), Moses fulfills the role not of active mediator but of intermediary. Nor in (15) can the human attribute anima be considered an agent.

(14) Quod nimirum ueritas semper esse suum ut nobis, utcumque infunderet Moyse mediante insinuat dicens: ego sum qui sum (Gregorius Magnus, Moralia in Iob 4, 32)

"Undoubtedly, the truth reveals that this is always his nature, whatever may be the way in which it has been imparted to us through Moses, whan he said: I am who I am"

(15) miror autem tibi uideri sonitum uocis illius, qua dictum est: tu es filius meus, non mediante anima sed diuino nutu sola corporali natura sic fieri potuisse (Augustinus Hipponensis, Epistulae $169,44,3)$

"I am surprised that you think that the sound of that voice with which it was said: You are my Son, could not had been be produced by the soul but by divine will under a purely corporeal nature"

In contrast, on other occasions, the agentive reading is imposed quite clearly; that is, the effective agentivity of the name that accompanies mediante is verified. Correspondingly, in these cases, mediante usually demonstrates a verbal behavior. Far from the merely adjectival function of the previous examples, it can be seen in (16) and (17) respectively that mediante develops the complements cum possesoribus and inter carnem deumque.

(16) aut eorum carpenta itinere longiore quassantur aut animalia attrita languescunt, te custode atque mediante cum possessoribus sine aliqua oppressione mutentur (Cassiodorus, Variarum libri duodecim 5, 10, 15)

"If the carriages are broken because of a road that is too long, or if the animals languish, through tiredness, with you acting as a guardian and mediating with the owners, they can be replaced without any pressure"

(17) Et filius ergo dei nascitur ex uirgine non principaliter soli carni sociatus, sed anima inter carnem deumque mediante generatus. (Rufinus, Expositio symboli 11)

"Thus, the Son of God is born of the Virgin not united directly to the flesh, but generated with the soul mediating between the flesh and God."

In spite of what has been discussed so far, in the Patristic Period, we also find cases of absolute constructions with mediante, but these correspond in their entirety to lexicalized expressions that select God as the subject: Deo mediante, Domino mediante, Christo mediante, and are quite unproductive in Latin.

\subsection{In Search of Other Values}

The differentiation of senses and meanings of mediante that we have been discussing from the Patristic Period does not seem to be bound to a particular order of the constituents of the construction. Examples are distributed 50-50 between SV and VS orders, and many highlight the irrelevance of order, be they temporal senses, as in (18), or sociative-instrumental ones, as the frequent occurrences of anima in (19) show.

(18) a. Iam die festo, ait, mediante ascendit dominus in templum (Petrus Chrysologus, Collectio sermonum 85 , line 9 )

b. Sic die festo mediante ascendit dominus in templum (ibid. line 15)

c. quia Iesus [ ... ] mediante die festo [ ... ] ambulauit (ibid. 85bis) 
(19) a. uerbum autem incommutabile [...] particeps carnis effectum est rationali anima mediante (Augustinus Hipponensis, Epistulae 140, 44, 4)

b. tu es filius meus, non mediante anima sed diuino nutu (ibid. 169, 44, 3)

c. Propterea namque deus corpori anima mediante commixtus est (Dionysius Exiguus, Exempla sanctorum patrum 88)

d. et qui immensus est, capitur mediante anima deo et carni (ibid. 90)

e. qui mediante anima, in eius utero fieri dignatus est per humanitatem corpus. (Gregorius Magnus, Moralia in Iob 18, 20)

f. Carnem quippe diuinitas anima mediante suscepit (ibid. 31, 23)

g. cum unigenitus dei filius in seipso intra uterum uirginis mediante anima, humanum sibi corpus creauit (ibid. 33, 16)

h. filius enim, inquit, dei nascitur ex uirgine, anima inter carnem deumque mediante generatus (Iohannes Cassianus, De incarnatione Domini contra Nestorium 7, 27)

i. qui inmensus est, capitur, mediante anima deo et carni (ibid. 7,28$)$

It has proved to be impossible to document syntactically-possible prepositional values of mediante for this period of Latin, since there are no cases of non-agreement or of constituent order, which would be critical for their detection. Although some semantic contexts may suggest the incipient development of the preposition, it seems clear that these do not correspond with either those which select temporal nouns or even with nouns of effective agentivity, given the limited possibilities which these nouns have of being interpreted and reanalyzed as 'means'. These points aside, prepositional values seem to appear quite clearly with nouns that have both the typical and derived functions of the instrumental ablative. This is perfectly logical because, semantically, the original values of mediante as an ablative are very close to its new prepositional functions.

\section{Scholastica mediante}

During the centuries of the so called Carolingian Renaissance, and even in the following two centuries, the presence and use of mediante in Latin underwent no substantial change: perhaps the number of occurrences increases somewhat (68 cases between the 8 th and 11th centuries), but it still does not have a significant frequency and, moreover, the differentiation of meanings does not depart fundamentally from those which we have pointed out. We do not think it necessary to dwell on this here, but by way of example, Table 2 gives the data collected for the 22 instances recorded for the 9th century:

Table 2. Distribution of uses of mediante, 9th century.

\begin{tabular}{|c|c|c|c|}
\hline Lexical Feature & \# of Occurrence & noun & Constituent Order \\
\hline [+ temporal] & 8 & $\begin{array}{l}\text { festus dies (6) } \\
\text { octaua hora } \\
\text { regnum }\end{array}$ & $\begin{array}{c}\text { VS (4)/SV (2) } \\
\text { VS } \\
\text { SV }\end{array}$ \\
\hline $\begin{array}{c}{[- \text { temporal }]} \\
{[ \pm \text { concrete }]}\end{array}$ & 14 & $\begin{array}{l}\text { anima (5) } \\
\text { conciliator } \\
\text { delectatio } \\
\text { Dominus } \\
\text { intercapedo } \\
\text { pietas } \\
\text { scientia } \\
\text { sensus (2) } \\
\text { uirtus }\end{array}$ & $\begin{array}{c}\text { VS (4)/SV (1) } \\
\text { SV } \\
\text { SV } \\
\text { SV } \\
\text { VS } \\
\text { VS } \\
\text { SV } \\
\text { VS } \\
\text { VS }\end{array}$ \\
\hline
\end{tabular}

As we can see, the use of mediante with a temporal value is quantitatively less than its use in the sense of mediation, especially if we consider that 6 of the 8 occurrences revolve around dies festus of the biblical text. Meanwhile, among the nouns that do not relate to time, those related to human 
entities predominate. As to the order of the constituents, this is quite free and does not seem to provide relevant information about the syntactic behavior of mediante.

In contrast (albeit slight) to this still very modest use of mediante, from the 12th century onward and mostly throughout the 13th and 14th centuries, the increasing presence of constructions in which mediante appears is striking, to the point that it becomes quite difficult to explain it away as a link in an evolutionary development that occurs uninterruptedly from the first Patristic examples.

To our knowledge, the arrival on the scene of Scholasticism-from the Early Scholasticism of the 11th and 12th centuries, but especially the High Scholasticism from the 13th century to the end of the Middle Ages_-played a decisive role in this matter. As is well known, Scholasticism—as a dominant theological-philosophical doctrine in medieval thought-is characterized by continuity with respect to ancient Patristics, but, unlike the latter's style of theology, it is marked by exegesis and biblical glosses, and is guided primarily by the criterion of authority. Scholasticism shifts to a more speculative theology, demonstrating its theses with reasoning and applying dialectic methods (Llopis Cardona 2015, p. 199). On the other hand, it is also important to bear in mind that Scholasticism expands its scope of work to other discursive contexts, largely due to the integration of Aristotelian philosophy in its theological doctrine. In this sense, we must not forget that much of the work of the scholastics and schools of translators during the 12th and 14th centuries is marked by translations into Latin of almost all the works of Aristotle and the numerous commentaries on these.

This is not our aim here, nor can we attempt to go into the detail of this very complex activity and its extremely varied results. We put forth this proposal because we believe it is possible to establish in the history of Latin a second entry point for constructions with mediante, transferred from Patristicism, but in much greater volume and with fairly fixed uses, which could well explain the common pattern with which the construction comes into Italian, French, Catalan and Spanish (cf. Garachana in this volume).

The Scholastics, imbued whith patristic literature, but also concerned with reasoned arguments, found in the incorporation of mediante into Latin a particularly transparent and suitable linguistic element for the more explicit, or graphic, expression of means and cause. Since there was a guarantee of semantic proximity, existing construction with mediante could be reanalyzed and serve, along with other prepositional phrases, to make up for the progressive loss of the use of the ablative without preposition in medieval Latin. ${ }^{13}$

\subsection{Development and Extension of Mediante}

The hypothesis of the influence of Scholasticism in the development of the prepositional values of mediante is supported by the data. Indeed, quantitatively, they are quite striking: for example, in the number of uses of mediante in the works of each of the main representatives of High Scholasticism, which surpasses in each case the total of 52 uses we found across the earlier period; see Table 3. A comparison of the total figures for both periods is also overwhelming.

Broadening the focus somewhat over the centuries when Scholasticism flourished, we can see that as against 52 cases of mediante registered for the Patristic Period (understood to be, as we have said, between the 2nd century AD and 753), we find in the Brepols corpus 4545 occurrences for the entire Middle Ages, between the year 736 and 1500. Certainly, these figures should be considered in proportion to the number of words in the corpus for each period: 30,578,827 in the Patristic Period and $103,889,649$ in the Middle Ages. Nonetheless, as percentages, the ratio is 1.70 occurrences per million words in the first period to 4.37 occurrences per million words in the second; see Table 4.

13 See Bastardas Parera (1953, pp. 50-51). 
Table 3. Occurrences of mediante in the High Scholasticism.

\begin{tabular}{ccc}
\hline Representatives of High Scholasticism & $\begin{array}{c}\text { \# of Occurrences in High } \\
\text { Scholastic Period }\end{array}$ & $\begin{array}{c}\text { \# of Occurrences in } \\
\text { Patristic Period }\end{array}$ \\
\hline Albertus Magnus (c. 1193-1280) & 59 \\
\hline Bonauentura (1217/1218-1274) & 364 \\
\hline Rogerus Bacon (c. 1219-c. 1292) & 61 \\
\hline Thomas Aquinas (1224/1225-1274) & 651 \\
\hline Iohannes Duns Scotus (1265/66-1308) & 131 \\
\hline Guillelmus of Ockham (c. 1290/1300-c. 1349/50) & 412 \\
\hline Total & 1678 \\
\hline
\end{tabular}

Table 4. Frequency per million words of medians, -ntis in the Patristic Period and the Middle Ages.

\begin{tabular}{ccc}
\hline & Patristic Period & Medieval Writers \\
\hline nom. sg. m. f. n.-ac. n. & 0.03 & 0.48 \\
medians & $1 / 30,578,827$ & $50 / 103,889,649$ \\
\hline $\begin{array}{c}\text { ac. sg. m. f. } \\
\text { mediantem }\end{array}$ & 0.0 & 0.19 \\
\hline $\begin{array}{c}\text { gen. sg. m. f. n. } \\
\text { mediantis }\end{array}$ & $0 / 30,578,827$ & $20 / 103,889,649$ \\
\hline dat. sg. m. f. n. & 0.03 & 0.11 \\
medianti & 0.0 & $12 / 103,889,649$ \\
\hline abl. sg. m. f. n. & $0 / 30,578,827$ & 0.01 \\
mediante & 1.7 & $2 / 103,889,649$ \\
\hline nom.-ac. pl. m. f. & $52 / 30,578,827$ & 4.37 \\
mediantes & 0.0 & $4545 / 103,889,649$ \\
\hline nom.-ac. pl. $\mathrm{n}$. & $0 / 30,578,827$ & 0.08 \\
mediantia & 0.0 & $9 / 103,889,649$ \\
\hline gen. pl. m. f. n. & $0 / 30,578,827$ & 0.009 \\
mediantium & 0.0 & $1 / 103,889,649$ \\
\hline dat.-abl. pl. m. f. n. & $0 / 30,578,827$ & 0.009 \\
mediantibus & 0.13 & $1 / 103,889,649$ \\
\hline
\end{tabular}

We must say that this surprising sudden increase does not only have to do with occurrences of mediante. Unlike what we observed with respect to the first appearances of mediare in Latin, we now find that the participial form no longer exists only in the ablative case, but that there is also a slight extension to other cases in the paradigm. This is perfectly explicable and consistent with the extension undergone by the medieval Latin present participle. ${ }^{14}$

Along with the participle, in medieval usage there are also substantial increases, reaching hundreds of appearances, in instances of the finite forms of the verb, especially the present indicative, totaling 92 occurrences or 0.88 per million words compared to 0.22 or the 7 examples found in the Patristic Period. At this point, one could envisage a possible reformulation or at least a revitalization of the verb mediare as a denominative of medius, now encouraged by the extension of the present participle. In any case, the expansion and diversification of forms produces formally different utterances that are structurally and semantically similar, as illustrated in (20)-(22).

14 This extension of usage is illustrated in the study by Mesa Sanz (2004) based on the difficulties of translating the Latin present participle in Romance languages. 
(20) semper inter sphaericum et planum mediat aer (Iohannes Buridanus, Quaestiones in Aristotelis De anima lib. 1, quaest. 6)

"There is always air in the middle, between the spherical and the plane"

(21) Tertia opinio est adhuc medians inter istas duas opiniones (Franciscus de Marchia, Quaestiones super Aristotelis Metaphysicam lib. 1, quaest. 14)

"There is still a third opinion which is in the middle/mediates between these two opinions"

(22) Utrumque autem istorum modorum accidit semper uno minus esse intervalla (quae sunt propositiones) quam terminos: semper enim assumptum medium est inter extrema conjungibilia per medium: et talis conjungibilitas non potest esse nisi termini in uno (mediante inter duo) superent propositiones (Albertus Magnus, Analytica priora siue De syllogismo simpliciter (Commentarium in Aristotelis Analytica priora) lib. 1, tract. 5, cap. 5)

"With regard to both modes [of syllogism], it is always the case that the intervals (which are propositions) are one less in number than the terms: for indeed, the middle [term] is always taken as lying between the extremes which are related through this middle term: and such a relationship cannot occur unless the number of terms exceeds the number of propositions by one (that is, the one which mediates between them)"

\subsection{Prepositional Values}

The meanings of mediante in Medieval Latin did not differ significantly from those stated above, but the frequency of data allows us to specify some points and expand on others. Thus, first, we have the temporal sense, with the meaning "in mid-". It is a rare, almost vestigial sense. In a constructional context, it appears with a noun designating a period of time for which mediante indicates an approximately halfway stage. Predominant by far are the names of the months, but other types of periodization and nominalization of events are not excluded.

(23) Celebratum est autem hoc concilium Compostelle consilio regis et regine mediante quadragesima in era IC.LX-a. VIII Idus Marcii (Historia Compostellana 2, 52)

"This council was held in Compostela by advice of the king and queen in mid-Lent in the era 1160 on 8th of March"

(24) et novembrio mense mediante (Theoctistus) ad hibernandum cum exercitu Saxoniam intravit (Ademarus Cabanensis, Chronicon 2, 13)

"And in mid-November (Teoctist) entered Saxony with his army to spend the winter"

The lexical features of the temporal terms naturally prevent them from functioning normally in non-temporal contexts, so it is not easy for the prepositional sense of mediante as we know it to be generated. However, if we consider the order of the constituents of the phrase as a way of detecting possible prepositional meanings (König and Kortmann 1991, pp. 114-15), we must say that in this period we observe certain alternations between SV and VS, which seem to depend on the greater or lesser degree of integration of the temporal complement into the predication and which, moreover, may guide later developments. Thus, in example (23) "mid-Lent" works directly as an adjunct of the verbal predicate "was held". The VS order of the syntagm seems to demonstrate the strict relationship between mediante and the verb, and therefore, suggests a route to a prepositional use that would not succeed. However, in "mid-November" from example (24), the item in the topic position affects the entire sentence by setting the time frame in which the entry of Teoctist in Saxony occurs. Here, the different syntactic level of insertion of the adjunct appears to involve maintaining the Classical order of the constituents, and at the same time, poses serious difficulties for prepositional development. We will return to this when we consider the other meanings of mediante.

When mediante occurs in reference to ablative nouns whose function is not spatial-temporal, the syntagm in which it appears has principally either sociative-instrumental meanings, or causative and circumstantial ones. Because they all share common characteristics, these functions are often difficult to distinguish because they really depend on the lexical features and restrictions imposed by 
the predicates and by the context itself. Thus, for example, in (25) and (26), we have the two nouns "glass" and "mirror," with the feature [+concrete], which are easily interpretable as observational instruments. But while in (25) the predicate selects glass essentially as an instrument or medium through which a body is seen, in (26), the mirror appears as an object causing partial vision. Meanwhile, what differentiates mediante Ioanne, in example (29) from those immediately preceding it, mediante interpositione (27) or mediante scientia (28), is the feature [+ human]. This allows a controlled predication that is inconvenient for the abstract nouns (27) and (28), which are usually interpreted as modal or circumstantial complements.

(25) Sed quando corpus album videtur mediante vitro viridi, sensus apprehendit aliter quam sit, quia apprehendit illud ut viride, et ita iudicat (Tomasso d'Aquino, Quaestiones disputatae de ueritate, quaest. 1, art. 11, contra 3)

"But when a white body is seen through a green glass, the sense apprehends it in a way which is different from what it actually is, since it apprehends it as green, and so it considers it to be"

(26) Item, notandum quod speculum est causa partialis visionis quae causatur mediante speculo (Gulielmus Occamus, Quaestiones in librum tertium Sententiarum (reportatio), quaest. 4, p. 146)

"In the same way, it should be noted that the mirror is the cause of the partial vision that is caused by the mirror"

(27) set multa bona in istis [particularibus] accidunt mediante interpositione mali (Rogerus Bacon, Questiones supra libros prime philosophie Aristotelis (Metaphysica I, II, V-X) lib. 9, p. 316)

"But many good things come to these particulars through the interposition of evil"

(28) prudentia quae [...] ascendit per intellectum ad sapientiam descendit autem in artem mediante scientia (Bonauentura, Collationes in Hexaemeron, Visio prima, coll. 2, par. 13)

"Prudence, which [...] ascends through the intellect to wisdom, descends instead to art by means of science"

(29) Petrus vero mediante Ioanne instruitur a Christo (Tomasso d'Aquino, Super Euangelium Iohannis reportatio, cap. 13 , lect. 4 , num. 1806, lin. 20)

"Peter is instructed by Christ through John"

The same difficulty in drawing precise boundaries between these phrases explains why, generally, all may be susceptible to reanalysis as the object of a preposition mediante, insofar as their respective semantic functions refer more or less metaphorically to the medium through which something occurs. In fact, as we are able to show, there are hardly any restrictions in these cases on the selection of the noun that agrees with mediante, with the single exception of temporal nouns.

Similarly, it is also interesting to see that an extension of categorial selection takes place in medieval Latin - unlike the previous period-since we find mediante agreeing not only with nouns, but also with pronouns, both personal as well as demonstrative and indefinite, and beyond that -in what undoubtedly represents an advance along the path toward prepositional senses-with relative pronouns (30) and (31), and even with interrogative pronouns that introduce completive clauses, that is to say, in indirect questions. ${ }^{15}$

15 We may add that when mediante appears in agreement with a relative pronoun, mediante usually precedes it. Among the Scholastic writers, we have only observed a clear reluctance to such anteposition in Thomas Aquinas.

\begin{tabular}{|c|c|c|}
\hline & quo/qua mediante & mediante quo/qua \\
\hline Albert the Great & 0 & 7 \\
\hline Bonaventure & 19 & 15 \\
\hline Roger Bacon & 1 & 10 \\
\hline Thomas Aquinas & 34 & 0 \\
\hline Duns Scotus & 3 & 2 \\
\hline William of Ockham & 2 & 17 \\
\hline
\end{tabular}


(30) Percussio balistae in sagittam generat actionem in sagitta, mediante qua sagitta uolat per aerem mouens se ipsam (Raimundus Lullus, Excusatio Raimundi (op. 141), quaest. 2, lin. 229)

"The blow of the crossbow on the arrow generates in the arrow an action by means of which the arrow flies by the air moving itself"

(31) nam, quamvis species coloris sit illud mediante quo color videtur, tamen non oportet quod illa species videatur (Iohannes Buridanus, Quaestiones in Aristotelis De anima, lib. 3, quaest. 11)

"For although the appearance of color is the means by which color is seen, it is not necessary that this appearance be seen"

(32) sed non erit invenire mediante quo insit aeri: ergo inest per se (Albertus Magnus, Commentarii in secundum librum Sententiarum, dist. 13 C, art. 2)

"But it will not be found through what (light) is present in the air; then it is present by itself"

The above examples (30)-(32) highlight an extension of the scope of mediante that allows for the emergence of clearly prepositional senses. Moreover, it should be stressed that the subcategorisation of a relative pronoun by mediante stresses the coreferentiality of the phrase with the main predication, and is therefore far removed from the absolute construction. ${ }^{16}$

As a further demonstration of categorical expansion, we can add examples in which mediante subcategorizes a nominalized infinitive (33) and (34), or even grammatical words (35) and (36):

(33) potest causare tristitiam vel delectationem in voluntate sine omni actu libere elicito, sed solum mediante velle naturali qui non est actus elicitus (Gulielmus Occamus, Quaestiones uariae: Notabilia, dubitationes et determinationes, quaest. 6, art. 9)

"It can cause sadness or delight in the will without a voluntarily unlawful act, but only through natural will, which is not an unlawful act"

(34) Fundamentum autem filiationis est essentia mediante actu passivo originis, scilicet mediante generari, sicut est fundamentum paternitatis mediante generare active (Gulielmus Occamus, Scriptum in librum primum Sententiarum (ordinatio), vol. 3, dist. 5, quaest. 2)

"The foundation of filiation is essentially through a passive act of origin, that is to say through being generated, just as the foundation of paternity is through actively generating"

(35) In secunda autem solutione primo attribuebat accidenti quod quid est, [...] et mediante quod quid est attribuebat ei definitionem (Sigerus de Brabantia, Quaestiones in Metaphysicam lib. VII, 10) "In the second solution he attributed to the accident the quod quid est [...] and by means of the quod quid est he attributed the definition"

(36) Quandoque significat differentiam et tunc construitur cum accusatiuo mediante inter (Folchinus de Borfonibus, Cremonina (Grammatica, orthographia et prosodia), pars 3, cap. 4, lin. 1191)

"And when (the verb interest) means a difference, then it is constructed in the accusative with inter"

Another factor that is useful in confirming the reanalysis of these constructions as prepositional phrases is the invariability of the case and number of mediante and the consequent lack of agreement between noun and participle. Although it is not always possible to find examples in the same Patristic context, the example in (37) is illustrative, in which number agreement is broken, and further in example (38), where the lack of case agreement paves the way for a phrase in which mediante governs an accusative as the object of the preposition. ${ }^{17}$

16 It is perhaps worth remembering that the ablative absolute of the Classical period has a syntactic limitation, in the sense that there can be no overlap between the subject and a nominal element of the main predicate. If there is such co-reference, a participial construction is employed, but not an absolute. However, it is also known that already in Low Latin and especially in Medieval Latin this prohibition is quite lax and there are numerous documented cases in which the subject of the absolute ablative may reappear in the main clause (Bassols de Climent 1945, vol. I, pp. 459-61).

17 The same sequence vobis mediante in example (37) we find also in a letter from Berengaria of Navarre to the Bishop of Winchester, which asks him to mediate with his brother (https://epistolae.ccnmtl.columbia.edu/letter/765.html). But we 
(37) episcopalem dignitatem ordinis a Deo uobis mediante recipiam (Historia Compostellana 3, 34) "That I may receive from God through you the episcopal dignity of the order"

(38) Hilarius non intendit hic dicere quoniam sit distinctio personis suppositis secundum veritatem in hoc verbo Faciamus, sed mediante falsum et verum secundum oppositionem haereticorum, qui destruebant pluralitatem personarum (Alexander Halensis et al.ii, Glossa in quattuor libros Sententiarum: glossa in librum primum, dist. 23, num. 17, p. 231)

"Here Hilary does not mean to say that in this verb faciamus there is a distinction between the supposed persons in accordance with the truth, but through a false [God] and a true [God] according to the opposing stance of the heretics, who denied the plurality of persons"

Finally, we must turn to the order of constituents. Although it is commonly accepted, somewhat simplistically, that medieval Latin had already consolidated the Romance verb inversion in sentences, it is important that in this paper we consider the extent to which not only syntactic context but also semantic conditions favor or not the positioning of the noun before the participle.

The truth is that the data is overwhelmingly in favor of the preposing of the participle; see Table 5. To prove this, we return again to the selection of the most representative authors of Patristic Period.

Table 5. Order of constituents of mediante in constructions in the Scholastic Period.

\begin{tabular}{cccc}
\hline & \# of Occurrences & $\mathbf{N}+$ mediante & mediante $+\mathbf{N}$ \\
\hline Albertus Magnus & 59 & 4 & 55 \\
\hline Bonauentura & 364 & 30 & 334 \\
\hline Rogerus Bacon & 61 & 2 & 59 \\
\hline Thomas Aquinas & 651 & 138 & 513 \\
\hline Iohannes Duns Scotus & 131 & 6 & 125 \\
\hline Guillelmus of Ockham & 412 & 2 & 410 \\
\hline
\end{tabular}

On the one hand, we must accept the validity of the observations made above regarding the constituent order of phrases containing temporal nouns, in the sense that the placing of mediante before the noun is in keeping with the greater dependence of the phrase on the verbal predicate. We will focus on example (39), where the first appearance of the phrase anima mediante sees its constituent order reversed immediately afterwards. Apart from the metric clauses that could be invoked for this kind of prose, it seems clear that the verb plays an important role in the encoding of these complements. First we have a transitive verb, assumpsit, with a direct object, corpus, and a syntagma anima mediante functioning as a peripheral adjunct expressing the circumstances involved in becoming the flesh of Christ. Meanwhile, pervenit, besides being an intransitive verb, is a motion verb, so that it is naturally completed by the argument ad corpus, but at the same time, their semantic characteristics clearly favor adding mediante anima to the verbal predicate as an adjunct with a prosecutive function, that is, as an expression of the means by which the spirit reaches the body.

(39) [Christus] corpus assumpsit anima mediante: tum etiam ratione spiritualis influentiae, quae pervenit ad corpus mediante anima (Tomasso d'Aquino, In III Sententiarum, dist. 13, quaest. 2, art. 2)

"[Christ] assumed a body through the soul: and also because of the spiritual influence that reaches the body through the soul"

should recall that already in archaic Latin there is documentation of lack of number agreement with the participles of other verbs and first and second person plural pronouns. Thus, the grammarian Nonius Marcellus denounces the lack of agreement in Plautus, Amphitryon 400, praesente nobis, and fragment 6 of the comedy Auctio by Afranius, absente nobis. 
Moreover, we may add that in the cases analyzed we have observed that the phrase comprising mediante + $\mathrm{N}$ usually occurs within affirmative statements or those framed positively. For example, there are syntactical contexts with adversative correlations such as non ... sed, non ... nisi, where mediante appears as the second term, that is, where it not marked by negation. Interestingly, when that happens mediante precedes the noun. However, when mediante appears as the first term along with a negative element, especially the indefinite nullus, or in a context marked by negation, the order is invariably $\mathrm{N}+$ mediante. Example (40) is a good demonstration of this.

(40) Ad tertium dicendum, quod esse naturale per creationem Deus facit in nobis nulla causa agente mediante, sed tamen mediante aliqua causa formali: forma enim naturalis principium est esse naturalis (Tomasso d'Aquino, Quaestiones disputatae de ueritate, quaest. 27, art. 1, resp. ad arg. 3) "Thirdly, it must be said that God, through creation, does not make us the natural being by means of any agentive cause, but rather by some formal cause"

In our opinion, underlying this double order is the different semantic relation established with the predicate as a result of the different meaning which mediante acquires. When the ability to mediate is predicated on a noun representing an entity that is suspended by negation, it is difficult to reanalyze that entity as an instrument, a means, a cause, etc. The reasons are no different, for example, from those which make obstante a discourse marker in Spanish which appears mostly in the negative no obstante, where the suspension of the obstacle allows for its reanalysis as an inefficient cause. On the other hand, this is one of the few occasions where the suspension or exclusion of the noun with which mediante agrees allows the functional alignment of the phrase with authentic ablative absolutes, as happens, for example, in exceptive contexts. ${ }^{18}$ This would justify in these cases the SV order and suggest that the verbal properties of the postposed participle have been preserved (Giacalone Ramat 1994, p. 890).

\section{Recapitulation}

Mediante enters Latin in the Late Latin (2nd century AD). It does so as a grammatical calque from Greek, but its addition is certainly favored by the existence in Latin of the adjective medius, which is widely documented. In the ablative case, medio/media and mediante share meanings and behavior. Both can refer to a noun designating it fully or in part. Just as medio monte can mean "mountain in the middle" or "halfway up, in the middle of the mountain," it is possible to interpret ponte mediante as "on the bridge in the middle, which mediates" or "halfway along, in the middle the bridge."

The partitive designation is given only to nouns which have the feature [+ spatiotemporal]. Specifically, mediante selects temporal or similar nouns, for example, Iulio mediante "in the middle, mid-July". In all other cases, which are the vast majority, mediante pairs with ablative nouns with a sociative-instrumental value in its various meanings, especially that of a medium or cause: Deo mediante "through/with the mediation of God" odio mediante "through/because of hatred."

Thus, the origin of the prepositional senses of mediante lies in a participial construction in the ablative case, but not, as is often claimed and as occurred with other deverbal prepositions, in an ablative absolute construction. The latter, given its syntactic level of integration into the nuclear predication, can hardly provide the integration points needed for such prepositional senses to emerge. Usually, the ablative which goes with mediante constitutes a complement subcategorized directly by the verbal predicate, suitable for reanalysis as a prepositional phrase. Meanwhile, in most cases, mediante is deverbalized and shows a purely adjectival behavior.

In the few cases found in Latin from the Patristic Period, prepositional values of mediante emerge in a literature organized around the biblical text and embodied in glosses, exegeses and commentaries. Centuries later, Scholasticism adopts limited use of mediante in the Patristic Period and generously adapts it to its argumentative way of doing theology. It is employed in the techniques and discursive

18 See, for example, Giacalone Ramat (1994), and the case of excepto in Molinelli (2001). 
turns of Scholasticism, especially causal or justifying turns, which are at the basis of reasoning and the dialectic method. This discursive practice strongly promotes the use of mediante as the clear head of prepositional phrases, which is also worthy of note in explaining the emergence of mediante in Spanish and in approaching of grammatical mechanisms involved in its introduction. ${ }^{19}$

Beyond its morphological and lexical status, the semantic transparency of mediante is essential to its transcategorization. Its characteristic meaning (or rather, that of the whole of its semantic domain) allows it to function with ablatives of an instrumental nature, especially those of means and cause. In this way, its evolution undergoes a process of change along the lines of those that explain Latin prepositional uses of the nouns causa or gratia in the ablative singular (Fruyt 2011, p. 690), in which there is no semantic change and restructuring of meaning, but only a syntactic reinterpretation of the item in question. Thus, even though its Latin and deverbal origin has frequently led it to being lumped in with the others, mediante shares rather little with other Spanish prepositions, be they improper or imperfect, such as durante.

Funding: This research received no external funding.

Conflicts of Interest: The author declares no conflict of interest.

\section{References}

Bassols de Climent, Mariano. 1945. Sintaxis Histórica de la Lengua Latina. Barcelona: CSIC, vol. I-II.

Bastardas Parera, Joan. 1953. Particularidades Sintácticas del Latín Medieval. Barcelona: Escuela de Filología.

Castro Zapata, Isabel M. 2012. Del participio a la preposición. In Procesos de Gramaticalización de Durante y Mediante. Paper presented at Actas del VIII Congreso Internacional de Historia de la Lengua Española, Santiago de Compostela, Spain, 14-18 September 2009. Edited by Emilio Montero Cartelle and Carmen Manzano Rovira. Santiago de Compostela: Meubook, vol. I, pp. 721-33.

CDL. n.d. CDL: Cross Database Searchtool, Brepolis Library of Latin Texts Series A-B, Turnhout, Brepols. n.d. Available online: http:/ / www.brepolis.net (accessed on 31 December 2018).

Coleman, Robert. 1989. The Rise and Fall of Absolute Constructions: A Latin Case History. In Subordination and Other Topics in Latin. Proceedings of the Third Colloquium on Latin Linguistics, Bologna, Italy, 1-5 April 1985. Edited by Gualtiero Calboli. Amsterdam and Philadelphia: John Benjamins, pp. 353-74.

Company, Concepción. 2008. Gramaticalización, género discursivo y otras variables en la difusión del cambio sintáctico. In Sintaxis Histórica del Español y Cambio Lingüístico: Nuevas Perspectivas Desde las Tradiciones Discursivas. Edited by Johannes Kabatek. Madrid and Frankfurt am Main: Iberoamericana \& Vervuert, pp. 17-52.

Crespo, Emilio, Luz Conti, and Helena Maquieira. 2003. Sintaxis del Griego Clásico. Madrid: Gredos.

Fruyt, Michèle. 2011. Grammaticalization in Latin. In New Perspectives on Historical Latin Syntax. Edited by Philip Baldi and Pierluigi Cuzzolin. Berlin: De Gruyter, vol. IV, pp. 661-864.

Giacalone Ramat, Anna. 1994. Fonti di grammaticalizzazione. Sulla ricategorizzazione di verbi e nomi come preposizioni. In Miscellanea di Studi Linguistici in Onore di Walter Belardi. Edited by Palmira Cipriano, Paolo Di Giovine and Marco Mancini. Rome: Il Calamo, pp. 877-96.

Kabatek, Johannes. 2005. Tradiciones discursivas y cambio lingüístico. Lexis 29: 151-77.

König, Ekkehard, and Bernd Kortmann. 1991. On the Reanalysis of Verbs as Prepositions. In Approaches to Prepositions. Edited by Gisa Rauh. Tübingen: Narr Francke Attempto, pp. 109-25.

19 One aspect that we cannot address, but which, in our opinion, deserves study in some detail is the extent to which the causal relationship, which promotes, in our opinion, the development of mediante among the Scholastics, maintains only a connection with a certain discursive mechanism, or if it drives to the heart of fundamental doctrinal matters. Above we recalled how the Scholastics, and especially Thomas Aquinas, wove into their doctrine the major Aristotelian principles. On the principle of causality, formalized in the theory of four causes (matter, form, agent and end) is the source of all knowledge of the world and, specifically, the notion of efficient cause is essential in demonstrating the existence of God. Thus, it might not be unreasonable to think that the need for integration of these theoretical principles would have led Scholastics to use their own more elaborate channels and formulations for expressing cause. 
Kortmann, Bernd. 1992. Reanalysis completed and in progress: participles as source of prepositions and conjunctions. In Diachrony with-in Synchrony. Language History and Cognition. Edited by Günter Kellermann and Michael D. Morrissey. Frankfurt am Main: Lang, pp. 429-53.

Llopis Cardona, Ana. 2015. Tradiciones discursivas medievales e innovaciones: el caso de in hoc sensu. In Diskurstraditionelles und Einzelsprachliches im Sprachwandel/Tradicionalidad Discursiva e Idiomaticidad en los Procesos de Cambio Lingüístico. Edited by Esme Winter-Froemel, Araceli López Serena, Álvaro Octavio de Toledo y Huerta and Barbara Frank-Job. Tübingen: Narr Francke Attempto, pp. 183-207.

Lorenzo, Juan Lorenzo. 1998. El participio de presente latino: Auge y ocaso de una forma verbal. Cuadernos de Filología Clásica. Estudios Latinos 15: 37-58.

Mesa Sanz, Juan F. 2004. Participio de presente latino tardío y medieval. Entre norma y habla. ELUA, Estudios de lingüística: El verbo, 363-79. [CrossRef]

Molinelli, Piera. 2001. Absolute structures in late Latin. In De Lingua Latina, Novae Quaestiones. Paper presented at Actes du Xè Colloque International de linguistique Latine, Paris-Sèvres, France, 19-23 April 1999. Edited by Claude Moussy, Michèle Fruyt, Jacqueline Dangel, Lyliane Sznajder and Léon Nadjo. Leuven and Paris: Peeters, pp. 473-84.

Moreno Hernández, Antonio. 1996. The ablative absolute in Late Latin. In Aspects of Latin. Paper presented at Seventh International Colloquium on Latin Linguistics, Jerusalem, Israel, 19-23 April 1993. Edited by Hannah Rosén. pp. 471-82.

Sánchez Lancis, Carlos E. 2001-2002. La gramaticalización de los participios latinos de presente durante y mediante a través de las gramáticas y los diccionarios del español. Anuari de Filologia 11-12: 95-109.

Sánchez López, Cristina. 2014. Preposiciones, conjunciones y adverbios derivados de participios. In Sintaxis Histórica de la Lengua Española. Edited by Concepción Company. Mexico: Fondo de Cultura Económica-Universidad Nacional Autónoma de México, vol. 3, pp. 2055-180.

Serbat, Guy. 1979. L'ablatif absolu. Revue des Études Latines 57: 340-54.

Tarriño Ruiz, Eusebia. 2009. El adjetivo. In Sintaxis del Latín Clásico. Edited by José Miguel Baños. Madrid: Liceus, pp. 251-72.

THLL. 1900-present. Thesaurus Linguae Latinae. Electronic Resource CD. Teubner, Stuttgart \& Leipzig: K.G. Saur \& Walter de Gruyter.

Torrego, M. Esperanza. 2010. Les ablatifs de temps en latin. Facteurs pour leur interprétation. Revue de Linguistique latine du Centre Ernout. De lingua Latina 4: 1-16.

(C) 2019 by the author. Licensee MDPI, Basel, Switzerland. This article is an open access article distributed under the terms and conditions of the Creative Commons Attribution (CC BY) license (http:/ / creativecommons.org/licenses/by/4.0/). 


\title{
Article \\ The History of the Spanish Preposition Mediante. Beyond the Theory of Grammaticalization
}

\author{
Mar Garachana \\ Department of Hispanic Studies, Literary Theory and Communication, University of Barcelona, \\ 08007 Barcelona, Spain; margarachana@ub.edu
}

Received: 4 February 2019; Accepted: 12 April 2019; Published: 25 April 2019

\begin{abstract}
The most generally accepted diachrony of mediante assumes a grammaticalization path that started in an absolute clause, which first evolved into a preposition, and later into conjunction. However, data reveals that its development is not connected to an evolution in terms of grammaticalization. Indeed, mediante was introduced in Spanish in the fourteenth century as a consequence of syntactic borrowing from Medieval Latin. More specifically, this borrowing entered Old Spanish through Aragonese and Catalan (languages spoken in the east of the Iberian Peninsula). Since its first examples, mediante has acted as a preposition, and its form, connected to present participles, would give texts a cultured and Latinising air that was well-suited to the rhetorical guidelines of the European Renaissance and pre-Renaissance. Thus, this paper shows that the writer and rhetorical rules have become a key factor in the evolution of grammar.
\end{abstract}

Keywords: grammaticalization; absolute clause; Old Spanish; syntactic borrowing; Latinisms

\section{Introduction}

The rise of the preposition mediante 'with, through, by means of, via, with the help of' in Old Spanish has been explained in literature on grammatical change as a consequence of a process of grammaticalization that began in absolute constructions of the present participle (Castro Zapata 2010, 2012; Sánchez Lancis 2001; Sánchez López 2014, 2016). Whereas mediante is certainly connected with absolute constructions in Latin (cf. Bello 1988, p. 699), its evolution in Old Spanish is more complex than simply a process of grammaticalization, since the development of prepositional values of mediante was already completed in the Latin period. In fact, grammaticalization is not an explanatory hypothesis even for the emergence of mediante in the Latin period. Artigas (in this volume) convincingly demonstrates that the Scholastic authors syntactically reinterpreted an ablative construction that had been used sparingly in the Patristic period for the expression of means or cause. Therefore, the conceptual reinterpretation that characterizes the processes of grammaticalization is not observed in Latin either. If prepositional uses of mediante are already documented in Latin, it is not surprising that constructions in which mediante appears in Old Spanish are clearly prepositional except on rare occasions. ${ }^{1}$

The aim of this work is to analyze the origins of the use of mediante in Old Spanish in order to demonstrate that its emergence is the result of a grammatical borrowing. ${ }^{2}$ This borrowing would

1 As pointed out in Sánchez López (Sánchez López 2014, p. 2088). This has even been accepted by authors who argue for a grammaticalization process to explain the existence of mediante (see Castro Zapata 2012, pp. 722, 724).

2 As discussed in Sánchez López (2014), who, however, sometimes seems to exclude mediante from this process of copying from Latin:

Las preposiciones impropias durante, mediante, no obstante y no embargante derivan todas ellas de participios de presente: las dos primeras se utilizaban ya en latín dentro de cláusulas absolutas temporales o instrumentales; las otras dos corresponden al latín tardío o medieval, donde también aparecen especializadas para cláusulas 
have reached Old Spanish through the intense socio-cultural relations that Renaissance intellectuals maintained both in the Iberian Peninsula and elsewhere in Europe. In this context, the influence of Italy was key. This influence was introduced in the Iberian Peninsula by the intellectuals of the Crown of Aragon, who also maintained close relations with the most prominent Spanish authors of the period (cf. Pons Rodríguez 2015; Pascual 2016; Octavio de Toledo y Huerta 2017a, 2017b). Thus, we aim to demonstrate that the presence of mediante as a preposition in Old Spanish is closely related to socio-cultural factors that go beyond the narrow evolutionary margins proposed within the theory of grammaticalization $^{3}$ The intense cultural relations that were present in Western Europe during the fourteenth and fifteenth centuries led to grammatical borrowings that provided syntactic patterns shared among European languages - to the extent that some of these traits belong to what has come to be called Standard Average European. ${ }^{4}$

The hypothesis that mediante is the result of a borrowing from Latin into medieval Spanish, which was introduced from Aragonese and Catalan, seems more in line with the historical trajectory that the data show. Indeed, even uses of mediante that would be described as absolute clauses are, in fact, the result of rhetorical guidelines of the pre-Renaissance and the Renaissance. Therefore, our proposal implies broadening the analysis of grammatical changes and emphasizing the importance of history and culture in the evolution of languages. In other words, we believe that a rapprochement between historical linguistics and philology is essential to any research on grammatical change. ${ }^{5}$

This work is structured as follows. After this introduction (Section 1), I have devoted a brief section to the description of the corpus used and the methodology followed in this study (Section 2). Next, in Section 3, I have considered the evolution of prepositions in a typological context and reflected on the historical importance of the absolute clauses of present participles as a source of prepositions and conjunctions. In Section 4, I have described the grammatical values of the structures in which mediante appears in its first documented uses in Old Spanish in order to demonstrate its character as a grammatical borrowing. In Section 5, I have reflected on the importance of external factors as triggers of grammatical change. Next (Section 6), I have briefly discussed the emergence of the conjunction mediante que in Spanish. Finally, in Section 7, I have summarized the conclusions I have reached.

\section{The Corpus}

The data for this research are taken from the CORDE database, which is the most extensive historical corpus currently available in Spanish. ${ }^{6}$ In this way, I aim to ensure that the conclusions I obtain are the most representative of the language, in general, and do not reflect the rhetorical guidelines of a textual genre or the style of a writer or a group of writers.

absolutas en ablativo. Su cronología es muy similar: salvo no obstante que entra en el español como calco del latín medieval un poco más tardíamente, las otras tres se documentan desde los orígenes del español.

(Sánchez López 2014, pp. 2099-100)

"The improper prepositions durante, mediante, no obstante, and no embargante are all derived from present participles: the first two were already used in Latin within absolute temporal or instrumental clauses; the other two correspond to late or medieval Latin, where they also appear to have specialized as absolute ablative clauses. Their chronology is very similar: except for no obstante, which enters Spanish a little later as a calque from medieval Latin, the other three are documented from the origins of Spanish."

[my translation]

3 In other words, the humanist influence does not imply a re-latinization of the construction involving mediante, but rather it is the trigger for its introduction into the language (for a contrary opinion, cf. Sánchez López 2014, pp. 2084, 2088, 2100).

4 See Heine and Kuteva (2006) and Haspelmath (2001) on the Standard Average European concept. The work of Cornillie and Cornillie and Octavio de Toledo y Huerta (2015) is particularly relevant for Spanish. The most recent study on the syntactic influence of Latin on European languages is that of Cornillie and Drinka (forthcoming).

5 For more data on the importance of sociocultural factors on the evolution of Spanish, see Garachana Camarero (2018).

6 CORDE consists of 250 million words and texts of a variety of types from the time of the language's beginning up to 1974. 
However, I have excluded some texts from our analysis according to the textual criticism guidelines set out in Rodríguez Molina and Huerta (2017). For the study of the rise of mediante, it is especially important to handle original editions or copies made within 50 years of their composition. Since the fifteenth century — which was characterized by a clear desire to Latinize syntax-led to the incorporation of constructions in which mediante would appear to resemble a present participle, using copies from the fifteenth century to exemplify linguistic use in the fourteenth century could distort our results. Indeed, as we shall see, our research evidences that the use of mediante in the fourteenth century is not too far removed from that found in the modern language. In addition to data from CORDE, in specific places, I have resorted to the GRADIA corpus to supplement CORDE searches.

In this paper, I have adopted a usage-based approach to linguistic change. Therefore, I have analyzed the values of mediante in constructions documented in the corpora, as well as the characteristics of the texts in which they appear. ${ }^{7}$

\section{The Evolution of Prepositions in a Typological Context}

The evolution of deverbal prepositions deserves particular attention in the literature on grammatical change (cf. among others, the works of (Giacalone Ramat 1994; König and Kortmann 1991; Kortmann 1992); for Spanish see (Bosque 1989, pp. 197-99)). ${ }^{8}$ In European languages, the high number of prepositions originating from participles and gerunds has elicited this attention (cf. Kortmann 1992, pp. 431-32). The recurrence of this type of change can be explained by at least two factors. First of all, it should be noted that verbs, like prepositions, select complements. Thus, from a strictly formal point of view, they correspond to a similar construction: an element governing + an element governed. Secondly, participles are hardly prototypical verbal forms: in Spanish, they lack a morphology that expresses typical verbal values, such as person or mode and, unlike full verbs, they cannot constitute the nucleus of a predicate. In Spanish, this last aspect creates a point of contact with prepositions, which cannot form a phrase on their own but which always need to govern some element.

In addition, Kortmann (1992) points out that participial or gerundial absolute clauses share certain features with prepositional constructions, namely that they both can function as adjuncts with adverbial values and can complement a noun (see $1 \mathrm{a}$ and $1 \mathrm{~b}$, on the one hand, and $1 \mathrm{c}$ and $1 \mathrm{~d}$, on the other). This second property, in the case of Spanish, is rejected for the gerund by the educated norm (see $2 a$ and $2 b$ ). The RAE-ASALE (RAE-ASALE 2009, p. 2045) explicitly argues that adjectival uses are only possible with the gerunds of the verbs hervir 'to boil', arder 'to burn', and, with restrictions, colgar 'to hang up'. However, this adjectival use was admitted into the language of past eras for present participles, which, moreover, tend to evolve as adjectives (see $2 \mathrm{c}$ and $2 \mathrm{~d}$ ).

(1) a. Considering his family background, he is a most unusual man (Kortmann 1992, p. 436)

b. In many respects, he is a most unusual man (Kortmann 1992, p. 436)

7 The searches have taken into account the different spelling variants with which mediante has been documented in the history of Spanish, namely, mediante, medjante, and medyante.

8 In fact, synchronic studies have pointed out the importance of this type of research. In this sense, this affirmation in Bosque (1989, p. 199) is especially interesting:

La segunda pregunta afecta a la recategorización propiamente dicha: “¿por qué obtenemos unas veces preposiciones de los participios pasivos (excepto) y otras veces obtenemos adverbios (incluso)?". Es cierto que tanto esta pregunta como la anterior pertenecen al ámbito de la sintaxis histórica, pero las respuestas serían de enorme interés para los que trabajan en la teoría de las categorías gramaticales.

The second question concerns re-categorization proper: "Why do we sometimes get prepositions from passive participles (excepto 'except') and other times we get adverbs (incluso 'even')? It is true that both this question and the previous one belong to the field of historical syntax, but the answers would be of enormous interest to those who work on the theory of grammatical categories."

[my translation] 
c. Leave the box containing the dumbbells to me (Kortmann 1992, p. 436)

d. Leave the box with the green lid (Kortmann 1992, p. 436)

(2) a. *Caja conteniendo botellas de lejía

"Box containing bottles of bleach"

b. *El agua entrando en la pecera es la de la fuente (RAE-ASALE 2009, p. 2045)

"The water entering the fish tank is from the fountain"

c. Varones batallantes (Octavio de Toledo y Huerta 2017a, p. 73)

"Battling men"

d. De día parece un padre amante que a su adorada hija contempla ( ... ) (Benito Pérez Galdós, Los Ayacuchos, 1900, CORDE)

"By day he seems like a loving father who admires his beloved daughter"

The process that leads from participial (or gerundial) constructions to prepositions has been explained as a type of evolution that leads from lexical to grammatical categories. This would, therefore, be a change due to grammaticalization. Such a route of change has favored a theoretical apriorism that has led to the characterization of the evolution of mediante as a case of grammaticalization, even though its role was ALREADY that of a preposition from the time of its first use in the language (as has been said, the first examples of mediante are considered prepositions in (Sánchez López 2014; Castro Zapata 2012)). Moreover, as I pointed out above, examples can already be found in Latin in which the syntactic function of mediante is far removed from proper verbal values and can be characterized as prepositional values (cf. Artigas in this volume). ${ }^{9}$

Moreover, following Kortmann (1992, p. 438), prepositions and conjunctions deriving from participles are marginal members of their category, since they usually show features that differentiate them from the core group of prepositions. Namely:

- They usually have a low frequency of use, as a consequence of their stylistic markedness.

- They show greater morphological complexity: they have two or three syllables.

- $\quad$ Sometimes, in addition, they have recurrent internal constituents (Octavio de Toledo p.c. 28.5.17).

- If compared to more semantically bleached prepositions and conjunctions, they have a specific and quite complex meaning.

- They recall the structures from which they derive since the complement of the deverbal preposition can often still be interpreted as their direct object or subject.

In the case of mediante, it is used less frequently than other prepositions. For example, a quick search in CORPES XXI shows that, while 34,617 cases of mediante are documented, other prepositions are found to a greater extent (for example, desde 'from' is found 263,506 times and hasta 'to' 234,578 times). ${ }^{10}$ Mediante has three syllables, while the prototypical Spanish prepositions consist of one or two syllables ( $a$ 'to', ante 'before', bajo 'beneath', cabe 'next to', con 'with', contra 'against', de 'from', desde 'from, since', en 'in', entre 'between, among', hacia 'towards', hasta 'to, until', para 'to, for', por 'for, by', según 'according to', sin 'without', so 'under', sobre 'on, about, upon', tras 'after, behind'). ${ }^{11}$ Moreover, mediante, despite the fact that it is unstressed (Moliner 1966, s.v. mediante; RAE-ASALE 2009, p. 2230), is still described as having occasional uses as a present participle (RAE-ASALE 2009, p. 2230). Besides, mediante, together

9 Possibly, this fact could be related to the decline of the verbal values of the present participle in Vulgar Latin (in archaic Latin these had also been the exception, (cf. Campos Souto 2001, pp. 372-73)).

10 CORPES XXI is a corpus made by the Real Academia Española (RAE) that contains oral and written texts from the Americas, Spain, the Philippines, and Equatorial Guinea. The texts cover a period from 2001 to 2012. I have taken this corpus to test the low frequency of use of mediante as compared to other prepositions also in the contemporary language.

11 The prepositions cabe and so are infrequent forms in modern Spanish. 
with durante 'during', excepto 'except', salvo 'except', según 'according to', menos 'but, except', incluso 'even'12, forms a subclass among prepositions, that has been called "improper" (Bello 1988, pp. 738-40) or "imperfect" (Pavón Lucero 1999, p. 587). ${ }^{13}$ These non-prototypical prepositions do not assign the oblique case to their complements: *mediante mílti 'through me/you' (Bello 1988, p. 740; Bosque 1989, p. 198). For Bello, the fact that these prepositions do not assign oblique case harks back to their origin seems to prevent their full integration into the class of prepositions. Likewise, mediante does not assign nominative case either (Bello 1988, p. 740; Pavón Lucero 1999, p. 589).

Furthermore, these imperfect prepositions cannot govern infinitives, prepositional phrases, or sentences. However, at this point it should be remembered that prepositions, which express exclusively locative values, cannot govern sentences either: hacia 'towards', sobre 'on, about, upon', tras 'after, behind', bajo 'beneath', and ante 'before' do not form subordinate locative clauses (Pavón Lucero 1999, p. 571; 2010; Sánchez López 2016). However, it must be remembered that already since the Middle Ages mediante can govern a relative clause (example 3) and that from the sixteenth to the nineteenth century it could appear before an infinitive (example 4). It should also be noted that during the same period, mediante que 'because' existed as causal conjunction, typically with explanatory values (example 5). At present, however, only residual conjunctive uses are found in certain American varieties (example 6) ${ }^{14}$ If the conjunctive uses of mediante que do not persist in Spanish, it could be because this conjunction was competing with other synonymous conjunctions which were more firmly anchored in the language, such as dado que 'given that', visto que 'seeing that', como 'as', puesto que 'since'. Thus, the fact that mediante does not govern clauses in contemporary Spanish seems more to do with stylistic preferences than any real restriction on the preposition. All things considered, it cannot be denied that mediante holds a marginal position among prepositions, perhaps due to its having entered the language more recently. ${ }^{15}$

(3) Pero dexo al onbre sano \& franco. el libre aluedrio mediante el qual pudiese mereçer \& desmereçer allegarse o apartarse ala semejança \& nobleza de su fazedor que era y es dios (Fernando Mejía, Libro intitulado Nobiliario Vero, 1477-1485, CORDE)

"But to humans, sound and free, He left free will, through which they could deserve or not deserve to approach or to stray from the likeness and nobility of their creator who was and is God."

(4) a. Enterada S.M. la Reina Gobernadora del oficio de V.E. de 29 de diciembre último ha tenido a bien resolver que mediante haber cesado el riesgo que ofrecía la carretera de Aragón a Barcelona, y no ser tampoco grande el que presenta la que va desde aquella ciudad a Valencia, se despache la correspondencia pública de Barcelona por ambas carreras (Real Orden de 8 de enero, citada en Mariano José de Larra, "Buenas noches. Segunda carta de Fígaro a su corresponsal en París, acerca de la disolución de las Cortes, y de otras varias cosas del dia", siglo XIX, GRADIA)

"Her Majesty the Queen Governor being informed of Your Excellency's letter of December 29th last, she has seen fit to resolve that, since the risk posed by the road from Aragon to Barcelona has ceased, and that neither is the risk presented by the road going from that city to Valencia great, the public mail from Barcelona will be despatched by both routes."

12 No obstante, no contrastante, and no embargante were also members of this subclass of prepositions. However, the first has remained fixed as a discourse marker, and the second and third have disappeared from the spoken language (cf. Garachana Camarero 2018).

13 Giacalone Ramat (1994, p. 893) points out, following Kortmann (1992), that deverbal prepositions are not prototypical prepositions, but peripheral ones.

14 According to Sánchez López (2014, p. 419), the conjunction mediante que had particular vitality in the Spanish of the Americas, declining in the 18th century and remaining as a minority usage in the speech of some varieties of the Spanish of the Americas. For example, it is found in Paraguay, where de Granda (1979, p. 281) pointed out a possible grammatical calque from Guarani.

15 For Kortmann (1992, p. 438), the behavior furthest from the core of the category characteristic of improper prepositions is a reflection of a lesser degree of evolution. Generally speaking, this argument is also found in Company and Concepción (1997, p. 149). 
b. Que mediante no tener esa enunciada Vniversidad, Carcel, ni el Colegio avitacion alguna que pueda servir, para ella, sera mui util el que se conceda facultad para hacerla en el Suelo, del proprio Colegio (Anónimo, Real cédula, España, 1764, CORDE, Sánchez López 2016)

"That since the said University has no prison, nor any room in the college, which can serve for this purpose, it will be very useful to grant permission to construct one in the grounds of the College itself."

(5) Con la prevención que, mediante que en la mayor parte de Andalucía se gasta jabón blando, ( ... ) en lo que toca a dicho jabón blando no se haga novedad (Bernardo de Ulloa, Restablecimiento de las fábricas y comercio español, 1740-1746, CORDE)

"With the precaution that, since in most of Andalusia soft soap is used, [ ... ] no change shall be made with regard to the said soft soap."

(6) (... ) son mamás que quieran trabajar y no tengan dónde dejar sus hijos, para esas madres es la guardería, y que están utilizando bien, ¿verdad?, porque mediante que dejan acá, ellos (sic) van a trabajar (Encuesta 11, Asunción Servim de Eduardo, Paraguay; CREA, Sánchez López 2016)

“ $(\ldots$ ) they are mothers who want to work and don't have anywhere to leave their kids, that's who the nursery is for, and they're using it well, right?, because through leaving [them] there, they can go to work."

\section{The Evolution of Mediante}

\subsection{The State of the Art}

As pointed out in the introduction, the study of the evolution of mediante has been shrouded in theoretical and conceptual assumptions that have greatly distorted any explanation of its history. First, the emergence of mediante has been explained as a result of a need to increase the prepositional system due to the loss of the Latin case system (cf. Castro Zapata 2010, p. 1; 2012, p. 722). However, this explanation does not seem likely if we apply it to Spanish, where mediante is first documented at the end of the fourteenth century. Moreover, it should not be forgotten that, as Artigas (this volume) points out, the use of mediante in Latin seems to respond to an initial borrowing from Greek that only gained strength in twelfth-century Latin. In that century, mediante was mostly employed in a written variety of the language where its existence could have more to do with a desire for stylistic variation than with the loss of declensions, which affected the spoken language and which occurred before the Middle Ages. In addition to the chronological argument, it should be noted that the low frequency of examples of mediante in the Middle Ages makes it difficult to consider it as the result of grammaticalization meant to fill the gap left by the loss of Latin case.

Secondly, it has also been asserted that the introduction of mediante into Spanish was the result of an attempt to solve problems when translating into Spanish (Castro Zapata 2010, p. 3). However, this second possibility may be excluded on the basis of the studies by Pons Rodríguez (2015) and Azofra Sierra (2006). These scholars demonstrate that Spanish authors tended to avoid translating Latin present participles and usually opted for constructions more typical of Spanish syntax. Thus, Pons Rodríguez (2015) stresses the following:

el participio de presente falta o está muy aislado en la mayoría de los escritos del periodo, no figura en buena parte de los tratados despojados (Amicicia, Arboleda, Defensa de virtuosas mugeres ... ) y tampoco es común en las traducciones. (Pons Rodríguez 2015, p. 405)

"The present participle is missing or is infrequent in most writings from the period, it is absent in many of the treatises analyzed (Amicicia, Arboleda, Defensa de virtuosas mujeres ... ) and is not common in translations" [my translation]

In turn, Azofra Sierra (2006) points out in relation to the translations of Juan de Mena: 
En el caso de la traducción de la estructura que estudiamos, el latinismo más crudo, lo más ajeno al castellano, es la traducción por un falso participio de presente, es decir, una palabra terminada en-nte, formada sobre un lexema verbal y a la que se añaden los complementos verbales. Esto, como veremos, es lo menos frecuente: frente a esta traducción que violenta las reglas morfosintácticas del español, Mena se muestra prudente y prefiere adaptar los participios de otra manera. Hemos encontrado varias soluciones: traducción por un adjetivo en-nte, traducción por otro tipo de adjetivos, traducción por una subordinada con valor adjetivo (de relativo, de gerundio o subordinada sustantiva en función de complemento predicativo), y traducción por una oración independiente. (Azofra Sierra 2006, p. 69)

"In the case of the translation of the structure we are studying, the crudest Latinism and most alien to Spanish is a translation by a false present participle, that is, a word ending in -nte, formed on a verbal lexeme and to which verbal complements are added. This, as we shall see, is a less frequent phenomenon: when faced with such translation, which violates the morphosyntactic rules of Spanish, Mena is cautious and prefers to adapt participles in another way. We have found several solutions: translation by an adjective in -nte, translation by another type of adjective, translation by a subordinate clause with adjectival value (relative clause, gerund clause or subordinate noun clause functioning as a predicative complement), and translation by an independent sentence." [my translation]

Sin renunciar a ensayar nuevos moldes (léxicos y sintácticos) para la expresión culta y literaria, tomando como modelo la lengua latina, se decide [Juan de Mena] en la mayoría de las ocasiones por no forzar la sintaxis del romance y adapta los participios de presente con estructuras oracionales que respetan los valores de la forma originaria sin violentar los patrones sintácticos del romance. (Azofra Sierra 2006, p. 78)

"Without giving up trying new patterns (lexical and syntactic) for cultured and literary expression, taking the Latin language as a model, [Juan de Mena] decides in most cases not to force Spanish syntax and adapts present participles with clausal structures that respect the values of the original form without violating Romance syntactic patterns." [my translation]

In a recent study, Octavio de Toledo y Huerta $(2017 \mathrm{a}$, pp. 72,80$)$ confirms the conclusions of Azofra Sierra (2006) regarding the scant use of -nte forms with verbal value in Juan de Mena's Omero romançado.

In the specific case of mediante, it can be seen that, in translations from Latin texts, it often appears in passages without having been present in the original Latin. Thus, when Enrique de Villena uses mediante in his translation of the Aeneid, he always uses it in the glosses or in the preface and not in the translation itself. Ferrer Sayol uses mediante in the translation of Latin texts that do not contain this form.

Thirdly, studies that defend a change via grammaticalization to explain the prepositional value of mediante in Spanish ignore the fact that in the fourteenth and fifteenth centuries, the verbal use of present participles is not a patrimonial use, but a grammatical borrowing from Latin. This rhetorical artifice ended up being lost from the wider language, and its verbal values were assumed by the gerund (Bassols de Climent 1992, pp. 234-35 (Bassols de Climent); Muñío Valverde 1995). ${ }^{16}$ aquél en latín."

"( . . ) in the transition to the Romance languages, [the present participle] succumbs to an ablative gerund which will assume a good part of the functions it had carried out in Latin."

[my translation]

16 Campos Souto makes the same point (Campos Souto 2001, p. 373), explicitly stating that: “( ... ) en el paso a las lenguas románicas, [el participio de presente] sucumbe ante un ablativo de gerundio que asumirá buena parte de las funciones desempeñadas por 
The learnèd nature of the verbal uses of the present participle invalidates the grammaticalization hypothesis for Spanish, especially if we bear in mind that, in the case of mediante, these verbal uses are very vestigial. Moreover, the verbal uses of present participles have been described as a stylistic artifice, which attempted to mimic Latin syntax (Azofra Sierra 2006; Muñío Valverde 1995; Campos Souto 2001; Pons Rodríguez 2015) or, in the case of some biblical translations, Hebrew (see Pueyo and Enrique-Arias 2015). This rhetorical artifice, lost in the common language, left only a few traces in Spanish in the form of nouns or adjectives (amante 'lover', triunfante 'victorious', etc.) or in grammatical forms that already existed in Latin (mediante 'with, through, by means of, via, with the help of', no obstante 'in spite of, however') or which were created on this model (no contrastante 'in spite of, although', no embargante 'in spite of, although, however'). ${ }^{17}$

As a consequence of what has been explained, the presence of mediante in Spanish is neither the result of the need to compensate for the loss of Latin declension, nor the result of a change due to grammaticalization. It is, therefore, necessary to find another explanation for its introduction into Spanish.

\subsection{Not Every Grammatical Change Is Grammaticalization}

As I have argued, the fact that some of the uses of mediante in the medieval period are reminiscent of Latin absolute clauses has favored the explanation of evolution in terms of grammaticalization. Such uses are shown in examples like (7), in which the nominal phrase sana consideraçión 'proper judgement' functions as the subject of mediante. As such, the ensemble sana consideraçión mediante can be literally interpreted as "with a proper judgement mediating". According to the authors who defend this theoretical position, mediante must have followed an evolutionary line, such as the one outlined in (8). According to (8), the evolution of mediante must have come about from an absolute clause whose verbal nucleus would be mediante, which would be accompanied by a noun phrase in the ablative case acting as its subject. This construction would be reinterpreted as a prepositional phrase, which, in some contexts, could come to have a conjunctive function at the point that mediante extends its scope to include an entire sentence.

(7) si alguno mira a otro que le bien paresca o lo alaba de fermoso o de donoso, luego paresca daño en él de ojo, siquier de fasçinaçión. E aquí deven entender, sana consideraçión mediante, que la cabsa d'esto es que aquel que alaba la cosa mirada, pues se d'ella paga, paresçe en esa ora que mira más fuerte, firme e atentamente que otra, (Enrique de Villena, Tratado de fascinación o de aojamiento, 1422-1425, CORDE)

"If one person looks at another person in such a way that that person looks pleasing to him, or if he praises him as being handsome or graceful, then he will suffer damage to his eye, or "fascination". And by this must be understood, with a proper judgement mediating, that the cause of this is that since the person who praises the object of his gaze is pleased by it, it seems at that moment that he is looking more strongly, more firmly and more attentively at that than at anything else".

(8) [absolute clause [subject NP in ablative case] [VF present participle (mediante)] $>$ [pp [prep. mediante] $[\mathrm{NP}]]>$ [Causal SEnTEnce [Causal conjunction mediante que] [sentence]]

However, as we shall see, a careful analysis of the first documentation of mediante in Spanish shows that it was already behaving like a preposition in the fourteenth century, which is the time of its introduction into the language. The examples documented prior to this century are found in works preserved in later editions in which the presence of mediante may be due to the intervention of

17 See Garachana Camarero (2018) for the analogical influence of no obstante in the creation of no embargante and no contrastante. 
the copyist. There is, therefore, no need to propose the existence of two stages of the introduction of mediante into Spanish, one medieval and one Renaissance. ${ }^{18}$

As for the examples reminiscent of absolute ablatives, such as (7), they were rare, and their documentation is concentrated in the fifteenth century when the Latinizing influence is evident. Moreover, the cases of plural concordance between mediante and the accompanying nominal element are also concentrated mainly in the fifteenth century (see example 9).

(9) le fuemos rrebeldes; \& non obedeçimos el dicho del señor nuestro dios para andar en sus leyes que nos dio mediantes sus sieruos los profetas (Anónimo, Biblia romanceada, c.1400, CORDE)

"we were rebellious to God and did not obey his command to follow the laws that he gave us through his servants the prophets."

This plural agreement has been considered an argument in favor of the verbal value of mediante and has been proposed as an indication of the existence of a process of grammaticalization. However, the fact that mediantes appears far less than the singular mediante has been overlooked. Although it could be argued that this is because the accompanying nominal elements appear more frequently in the singular, we cannot dismiss the frequent cases of non-agreement in which the singular mediante accompanies a plural nominal element (10). Above all, we cannot ignore the desire to Latinize that permeates the rhetoric of the fifteenth century in Europe, which would have favored hybrid constructions, such as that of (15), in which mediante presents plural morphology and characteristics of a participle, but has a prepositional function. Thus, if the cases that could be cataloged as absolute clauses are Latinisms characteristic of the Spanish of the fifteenth century, and if the majority of the examples in which mediante appears in plural form can be considered hybrid structures in which mediante has the morphology of a participle, but the function of a preposition, the hypothesis of a grammaticalization process loses validity-at least if we want to conceive of it as a change that took place in Old Spanish.

(10) Segúnd avemos recontado, el rey que estaua en la çibdat, de Granada, después que mediante los fauores que ovo del Rey e de la Reyna fué reçebido por rey en aquella çibdat (Hernando del Pulgar, Crónica de los Reyes Católicos, 1480-1484, CORDE)

"As we have recounted, the [Moorish] king who was in the city of Granada, after he was received as king in that city as a result of the favors he obtained from the King and Queen [ ... ]

\subsection{The Introduction of Mediante in Old Spanish}

The first documentation of mediante in Old Spanish dates back to the fourteenth century (see Table 1). In this century, I have documented mediante on 13 occasions-having eliminated the cases found in works that did not meet the criteria for textual reliability set out in Rodríguez Molina and Huerta (2017). Of these 13 cases, 10 correspond to textual fragments in which mediante reproduces the temporal meaning of the Latin participle medians, -tis, used as an adjective and whose meaning 'to be halfway' is the result of translating the Greek verb $\mu \varepsilon \sigma o ́ \omega$ (cf. Artigas in this volume). This can be seen in examples (11) to (13), where mediante means 'in the middle of'.

18 For a different opinion, cf. Sánchez López (Sánchez López 2014, pp. 2157-58). She argues that, in the fifteenth century, there was a re-introduction of the construction with mediante, used as a participle and not as a preposition. The data, however, show that most of the examples in the fifteenth century are hybrid constructions in which mediante appears in a plural form, but has a prepositional function. In fact, in the fourteenth century, this usage already existed (see example 15). The examples from both the fourteenth and fifteenth centuries are the same grammatical calque, which imitated a Latin construction in which agreeing and non-agreeing forms alternated (cf. Artigas in this volume). The difference, if anything, has to do with the greater use of mediante in the fifteenth century, as this is the period of its embedding in the language, and the consequent greater presence of structures in which mediante offered a form that could suggest a present participle. However, this is not a sufficient reason to propose two different historical moments for the introduction of mediante in Spanish, especially when the first fourteenth-century documentations are found in the work of authors whose admiration for Latinisms is well known, namely, Juan Fernández de Heredia and Ferrer Sayol. 
(11) E aquesto deue hombre fazer quando ay echa la simjente. Si el jnujerno sera temprado. E que non sea pluujoso. deues sembrar la çeuada glatich que es blanca \& de grant peso. faza mediante enero en los lugares temprados. (Ferrer Sayol, Libro de Palladio, CORDE)

"And this must be done when the seed is sown there. If the winter is going to be mild and not rainy, you should sow lattic barley, which is white and heavy, until mid-January in temperate places."

(12) E quasi mediante febrero tu la sembraras en vn foyo. (Ferrer Sayol, Libro de Palladio, condE) "and around mid-February, you will plant it in a hole."

(13) E deuen se trasplantar de mediante agosto fasta a mediante setiembre con mucho estiercol. (Anónimo, Memoria de las labranzas. BNM 10211, 1385, coRDE)

"And they should be transplanted from mid-August to mid-September with a lot of manure."

Table 1. Distribution of the uses of mediante in the XIV-Xv centuries.

\begin{tabular}{cccccccc}
\hline Century & Preposition & $\begin{array}{c}\text { 'In the } \\
\text { Middle of' }\end{array}$ & Noun & Adjective & $\begin{array}{c}\text { Dios Mediante } \\
\text { and Other } \\
\text { Expressions }\end{array}$ & $\begin{array}{c}\text { Conjunction } \\
\text { Absolute } \\
\text { Clause }\end{array}$ \\
\hline XIV & $15.38 \%(2 / 13)$ & $\begin{array}{c}76.9 \% \\
(10 / 13)\end{array}$ & - & - & $7.6 \%(1 / 13)$ & - \\
\hline XV & $\begin{array}{c}85.5 \% \\
(213 / 249)\end{array}$ & - & $\begin{array}{c}4 \% \\
(10 / 249)\end{array}$ & $\begin{array}{c}0.40 \% \\
(1 / 249)\end{array}$ & $2.8 \%(7 / 249)$ & $\begin{array}{c}0.40 \% \\
(1 / 249)\end{array}$ \\
\hline
\end{tabular}

In the fourteenth century, I also find two cases that can already be described as prepositions: neither the syntax of the construction nor the meaning of mediante allows for an interpretation as an absolute clause. One of the examples documented in the fourteenth century shows an absence of agreement between the participle and its object (14): mediante has a clear instrumental grammatical use, characteristic of the modern language, where mediante can alternate with other prepositions or prepositional phrases, such as con 'with', gracias a 'thanks to', a través de 'through'. In fact, mediante las cañas can be glossed as 'with the canes, by way of the canes, through the canes'. Another clear indication of the prepositional value of mediante is the fact that it is introduced by the verb ligar 'tie'. I will discuss this example later.

(14) Otra manera ay de fazer vjñyas es a saber que hombre ha muchas cañyas al derredor de la parra o de la çepa. E ata hombre los sarmjentos a cada vna cañya al entorno. E los vnos sarmjentos se ligan con los otros mediante las cañyas. (Ferrer Sayol, Libro de Palladio, 1380-85, corde)

"There is another way of making vines, namely that you put many canes around the vine or the stock. And you must tie the shoots around each canes. And some shoots are linked with the others through the canes."

The other prepositional example of mediante in the fourteenth century, although showing concordance between mediante and the accompanying nominal phrase, is actually a hybrid construction: mediante shows present participle morphology, but a prepositional function. In fact, in (15), the participle appears in plural form, but the nominal complement that accompanies it is placed after it-as is characteristic of prepositional phrases-and the semantic value of mediante is close to the one in (14): mediantes las pregarias de los fieles can be glossed as 'by way of/thanks to the prayers of the faithful'. The only example that would allow us to venture an interpretation as an absolute clause would be (16); however, it is a construction close to the idiom Dios mediante 'with the help of God', which already functioned in Latin as an idiomatic expression (cf. Artigas, this volume).

(15) Et mayorment aquesto era en aquel tiempo quando haun por todo el mundo non auia alguna yglesia que, mediantes las pregarias de los fieles christianos, temprasse et amansasse las penas del 
mundo. (Juan Fernández de Heredia, Traducción de la Historia contra paganos de Orosio, 1376-1396, CORDE)

"And this happened mainly in the time when in the world there was not yet a church that thanks to the prayers of the Christian faithful, tempered, and calmed the pains of the world."

(16) \& enuio los en sçiçia a predicar la palaura de dios. la qual cosa los sobre dichos sanctos uarones la gracia de dios mediante con senyales \& uirtudes cumplieron. (Juan Fernández de Heredia, Gran crónica de España, I. Ms. 10133 BNM, 1385, CORDE)

"and sent them to Scythia to preach the word of God, which the above-mentioned holy men, through the grace of God, achieved with signs and virtues."

The situation described for the fourteenth century is modified in the century following. Thus, as shown in Table 1, the temporal values of mediante disappeared, overshadowed by the use of mediado 'in the middle of', with which mediante had been in competition since the time of Latin (cf. Artigas in this volume; Sánchez López 2014, p. 411). By contrast, in the fifteenth century, mediante begins to be documented as an adjective with the meaning of 'that which is in the middle' (17) and as a noun with the meaning of 'mediator, envoy, messenger' (18).

(17) Dize las treguas ser paz sequestra adora como a tiempo \& mediante o puesta en medio entre la guerra passada \& la guerra a venidera. (Alonso de Palencia, Universal vocabulario en latín y en romance, 1490, CORDE)

"He says that truces are an intermediate peace, a time that lies between, that is to say, between the past war and the future one."

(18) a. Mucho mejor puede alabar qualquier mediante al que ama e recontar sus virtudes que él mesmo; demás con menos suspeçión se puede fablar con el mediante que con el que ama. (Juan de Mena, Tratado de amor, c1444, CORDE)

"Any mediator can praise the one he loves and explain his virtues much better than he himself can, and with less suspicion, we can talk to the mediator than to the one that loves."

b. Interpres. tis. ( ... ). es nombre simple. ( ... no esta en vso. quiere dezir interprete. mediante: \& mensaiero: y el que traslada algo de vna lengua en otra. (Alonso de Palencia, Universal vocabulario en latín y en romance, 1490, CORDE)

"Interpres, -tis () is a simple name. ( . . ) it is not in use; it means interpreter, mediator, and messenger, and someone who translates something from one language to another."

c. Internuncius. es mediante: o mensaiero entre ambas partes. (Alonso de Palencia, Universal vocabulario en latín y en romance, 1490 , CORDE)

"Internuncius. Is a mediator or messenger between both parties."

Otherwise, most of the examples of mediante found in the fifteenth century can be described as prepositions. The order of the elements was the same as that in the prepositional phrases: mediante came before the nominal element governed by it. Furthermore, mediante also appeared in the singular as a fixed form, even if it was accompanied by a plural nominal phrase (19).

(19) La reyna doña ysabel, que tenía vn singular desseo de proueer en las yglesias de sus reynos de personas notables, suplicó al papa que proueyesse a este claro varón del obispado de córdoua, el qual fue proueýdo de aquella yglesia \&, mediante los ruegos y exortaciones que de parte de la reyna le fueron fechas, aceptó la prouisión que el papa le fizo de aquella dignidad. (Hernando del Pulgar, Crónica de los Reyes Católicos, 1486, CORDE)

"Queen Isabella, who had a singular desire to have notable people in the churches of her kingdom, begged the Pope to give the bishopric of Cordoba to this distinguished man, who was granted that 
church and, thanks to the pleading and exhortation of the Queen, accepted the Pope's granting him that dignity."

Moreover, even when the present participle shows plural agreement with the following nominal complement, its reading is usually that of a preposition with the above-mentioned values of 'with, by way of, thanks to'. Also, the syntax of the construction is mostly that of a preposition and not that of an absolute clause: the nominal element accompanying mediante is postposed in most cases. In fact, of the total of 37 cases with plural agreement documented in the fifteenth century, only eight have the noun phrase before mediante. Indeed, these are always fixed constructions in which the noun phrase in front of mediante is a personal pronoun or a demonstrative (ellos mediantes, aquellas mediantes 'because of them, thanks to them'). The remaining examples show the syntax typical of prepositional government and characteristic prepositional meaning. We are, therefore, dealing with hybrid constructions imitating rhetorical patterns which aspire to make Old Spanish more similar to Latin.

Example (20) shows this hybrid character of mediante when used in the plural: "la boz humana se faze mediantes ix. ofiçios" can be interpreted as 'the human voice is produced via/by way of/thanks to nine actions'. This gloss would be confirmed by the fact that mediantes ix ofiçios is a parallel structure to mediante agua $\mathcal{E}$ aire 'through water and air', which appears a little earlier in (20). In this case, the plural variant mediantes is not used, despite the plural nature of agua $\mathcal{E}$ aire 'water and air'. ${ }^{19}$ Moreover, in both cases, mediante is governed by the verb se faze 'it is made' on which it depends directly, which makes it difficult to attribute a verbal value to mediante and reinforces the hypothesis that it has prepositional value in (20). In the same vein, the [-animated] character of the noun phrase that accompanies mediante-mediantes prevents a mediation reading and favors their interpretation as prepositions denoting the instrument or means by or with which an action is achieved or accomplished. In other words, when the noun governed by mediante is a [-human, -animated, -agentive] noun, the event being talked about does not occur 'with the help or intervention of someone', but rather, since there is no entity that can perform any action, the interpretation of mediante with the sense of 'by way of, by means of' is triggered. When in the construction there is no agent controlling the action, an instrumental interpretation is activated. The noun that appears next to mediante no longer 'intervenes or helps' but becomes the means or instrument through which an action is carried out or a state is reached.

(20) Musam. desta causa dixeron algunos llamada de moys: por quel son dela musica mayor mente \& qual quier sonable boz se faze mediante agua \& ayre \& que por ende fingeron ser .ix. musas: por que la boz humana se faze mediantes .ix. ofiçios (Alonso de Palencia, Universal vocabulario en latin y en romance, 1490 , CORDE)

"Muse. Some called this the call of the muses, because the sound of the music and any voice that sounds is mainly done through water and air. Therefore, they pretended that there were nine muses since the human voice is produced through nine actions."

Examples in which mediante has a plural form (mediantes) often appear in constructions in which the noun phrase governed by mediante refers to people. This personal reference could favor an interpretation in terms of an absolute clause: the character [+animate, +human] of the noun that accompanies mediante can confer a predicative character on the construction in which mediante has both an adjectival and a participial value.

However, it is often the case, even when the nominal element that appears next to mediante refers to an animate entity, that we are far from the reading of an absolute clause, since the animate entity usually has the role of a means through which something is done or achieved and not of an agent that

19 Certainly, it could be argued that until the eighteenth century, with phrases formed by the coordination of two singular nouns, the verb could agree in both singular and plural. That said, it would seem that the presence of mediante that appears later could have tipped the balance in favor of the plural agreement. However, this does not appear to be the case. 
performs the action (Sánchez López 2014, p. 413). This is the case in example (21), in which even the personal pronoun ellos 'they' appears before mediante. This order and the agreement between mediantes and the personal pronoun in the third person could lead to a reading of 'with them intervening'. However, the reading of the whole passage favors an instrumental interpretation in terms of 'by way of them, thanks to them', which does not necessarily imply an active intervention of the children mentioned in the example. Rather, children are the means through which the father gains friends. Therefore, this use of mediante in (21) is closer to the semantics associated with the preposition, since the reading of this passage does not seem to confer any kind of agentive role on the referent of the animated noun phrase, but rather, as pointed out earlier, this prepositional phrase seems to denote an instrument through which an action is carried out or an event takes place. Thus, a Latinizing construction was being used for the expression of prepositional values. That is, to say, a Romance construction is hiding under a Latin guise.

(21) E si tanto el padre bive que los fijos a senio lleguen, exemplos buenos e menospreçio del mundo d'ellos como expertos confirmantes, speçializantes lo que él ha visto e cognosçido. Allende d'esto, en estas hedades las amistades que ellos mediantes ganan escusan de costas ganançiosas, acarreadas por ellos (Enrique de Villena, Tratado de la consolación, 1424, CORDE)

"And if a father lives so long that his children grow old, [they will become] good examples and will despise their world as experts who can confirm and detail what their father has seen and known. Beyond this, the friendships which [old people] gain at that age through [their children] compensate for what they have cost them."

The non-agentive character of the referent of the noun phrase [+animated, +human] that appears next to mediante (ellos mediantes) is further highlighted in examples, such as (22). In fact, in this case, it does not seem that the early prophets could be considered mediators, but rather the instruments through which the law was spread.

(22) fizieron pedernal en non oyr la ley que mando el señor delas huestes con su espíritu mediantes los prophetas primeros (Anónimo, Biblia romanceada. Real Academia de la Historia, p. 87, c1400, CORDE)

"they insisted on not hearing the law that the Lord of Hosts sent with his spirit through the early prophets."

Examples like (21) and (22) allow mediante to be considered a preposition that, on occasion, lends itself to rhetorical license, which was very much to medieval taste. In this sense, it is significant that the first example of plural mediante (mediantes) agreeing with a preceding noun phrase is not found in texts until 1424. Up to that point, the post-positioning of the nominal phrase was the rule, even when mediante appeared in plural form. This fact reinforces the hypothesis that the pre-position of the nominal complement and the plural agreement—otherwise a minority-appear to be more of a Latinizing trend with a syntactic structure closer to that of the mother tongue that could be achieved rather than effective use of an absolute clause in the Romance language. Significantly, the first examples with a nominal element positioned before mediante that have been retrieved in the work of Villena (an author known for his Latinizing syntax). ${ }^{20}$

Another indication that points to the possibility that the plural use of mediante was the result of a Latinizing trend is found in examples, such as (23), where the plural of mediante is used despite the fact that the nominal element governed by it appears in the singular. ${ }^{21}$

20 Sánchez López (2014, p. 416) also commented on the limited functionality of the Latinate constructions.

21 It could be argued, however, that the nominalizations with neuter lo can have a collective meaning which justifies the plural agreement. 
(23) "La santa santorum del tabernáculo enseñava el çielo emperial, que es asignado a la santa Trinidat et a los sus ángeles; et el santuario del tabernáculo, que era en doble mayor, enseñava e demostrava la tierra e la mar; por cuanto era común a los saçerdotes; la çaga del tabernáculo blanca enseñava el çielo christalino; las pieles, mediantes lo bermejo, enseñavan el çielo estrelloso del firmamento (Enrique de Villena, Tratado de Astrología, 1428, CORDE)

"The sanctum sanctorum of the tabernacle showed the imperial heaven, which is assigned to the Holy Trinity and their angels, and the sanctuary of the tabernacle, which was twice as large, showed the land and the sea since it was common to the priests. The rear of the tabernacle, which was white showed the crystalline sky; the hides, by means of the red, showed the starry sky of the firmament."

The syntactic and semantic behavior of constructions with mediante from their introduction into the language in the fourteenth century contributes to the idea that from this moment onwards we have to do with an instrumental or causal preposition. The constructions close to absolute clauses are the result of rhetorical artifice. In fact, the process of consolidation of mediante in Old Spanish is so advanced in the fifteenth century that there are documented examples in which mediante is followed by the preposition de (24). A century later, the preposition $a$ will be added (25). However, none of them will take hold. ${ }^{22}$

(24) a. Y quando fallare onbre ley y encomendanças tales que se alcançe mediante de sus çiençias y obras este grado angelical, ( . . ) ella sin dubda es la Ley, con la qual será seguro que permanesçerá su alma en el ligamiento de las vidas después de la muerte del cuerpo." (Anónimo, Traducción castellana del Libro de El Kuzari de Yehudah Halev, c1450, conde)

"And when a man finds such a law and such commendations that he can achieve this angelic degree through his knowledge and works, this is no doubt the law with which, he may be sure, his soul will remain in the union of lives after the death of the body."

b. La segunda rrazon es por que procurar saber las cosas aduenjderas mediante de los spiritus malignos es graue pecado. (Lope de Barrientos, Tratado de adivinar y magia, 1445, CORDE)

"The second reason is that it is a serious sin to try to know the things that will come through the evil spirits."

(25) Amigo di de buen grado que mediante a mi gran dios yo satisfare a los dos lo que me aueys demanda(n)do (Micael de Carvajal, Tragedia Josephina, a1540, condE)

"Friend, kindly say that through my great God, I will satisfy both of you in what you have asked of me."

The presence of these prepositions next to mediante has been explained as an example of the re-categorization of the present participle as a preposition (Espinosa Elorza 2010, p. 245). However, given that we already have clear examples of the prepositional value of mediante since the fourteenth century, it seems that the presence of $a$ 'to' and de 'of' (which have no semantic value in the constructions

22 However, they come to have sufficient significance for the conjunctive variants mediante de que and mediante a que to be developed.

(i) la cual mejora en cuanto a la dicha D.a Jusepa me pertenece, mediante de que como está dicho, yo pagué su dote de entrada en el convento y gasto. (Juan de Ayala, Testamento, 1658, CordE) "This improvement, in reference to the aforementioned Dona Jusepa, belongs to me since as has been said, I paid for her dowry to enter the convent and the associated expenses."

(ii) No puede estimarse por excesiva esta suma mediante a que en ella se incluye el valor del chile (José María Quirós, Memoria de Instituto, 1817, siglo XIX, CORDE) "This sum of money cannot be considered excessive as it includes the price of chili." 
mediante a or mediante de) was due to the strangeness of mediante as a preposition. When these prepositions were added to mediante, its inclusion in the paradigm of the prepositions was validated, conferring on the structures mediante $a$ and mediante de, the form of a prepositional expression. ${ }^{23}$ Something similar happened to no obstante de, no embargante de, and no contrastante de 'in spite of' (cf. Garachana Camarero 2018). Sánchez López (2016), following Berg (1998, p. 173), explains this type of change by analogical paradigmatic pressure, which particularly affects meaning-bearing words. ${ }^{24}$ Later on, Fisher (2011, p. 35) points to the formal or semantic similarity of new constructions with others belonging to a well-consolidated paradigm in the language as a decisive element in the consolidation of new forms in the language (Sánchez López 2016).

Another argument in defense of the grammatical status of mediante as a preposition is its early use in coordinated prepositional phrases, such as those of (26) and (27). These examples show that the prepositional phrase headed by mediante is coordinated with another one introduced by a synonymous preposition, with an instrumental (27) or causal (28) meaning, por 'with, through, by'.

(26) No biuos estantes. O no firmes. De quales naturas. De como se deuen dar o por quien: \& mediante quien. (Fernando Mejía, Libro intitulado Nobiliario vero, 1477-85, CORDE)

"Not being alive, or not [being] firm. Of what nature. On how they should be given or by whom: and through whom."

(27) y que por eso acostumbran los cristianos derramar con devoción agua bendita sobre las sepulturas, porque, mediante aquella santa agua y por la devoción con que allí se derrama, huyen los demonios de los monumentos [Talavera, Impugnación, 1478, CORDE]

"And that because of that Christians are accustomed to spilling holy water with devotion on the graves, because, through that holy water and through the devotion that is spilled there, the demons of monuments flee."

Further proof of the consolidation of mediante in the Spanish grammatical system can be found in the examples in which mediante governs a relative clause (28), an indirect question (29), or a completive clause (30).

(28) y ouo el grado singular espiritual mediante el qual se juntó al Nuestro Señor y a las ynteligençias separadas (Anónimo, Traducción castellana del Libro de El Kuzari de Yehudah Halevi, c1450, CORDE)

"and he had reached the singular spiritual level through which Our Lord and these different kinds of intelligence were joined."

(29) Los círculos, cuadrángulos y cuadrados que en él se consideran, las líneas diametrales, colaterales, verticales ( ... ) diagonales, orizontales y de la contingencia, y las demás, mediante con qué y por dónde ha de obrar (Luis Pacheco de Narváez, Advertencias para la enseñanza de la filosofía y destreza de las armas, 1642, CORDE)

"The circles, quadrangles, and squares which are included in it, the diametrical, collateral, vertical, [ ... ], diagonal, horizontal, and tangential lines, etcetera, with which and along which it will act."

(30) en lo que toca a cardoso el es moço muy onrad y visto su buen tino he hecho con el lo que me pidio mediante que me dixo queria muncho a vm. (Fernández Alcaide 2009)

23 I refer to the expanded paradigm of prepositions since in these cases mediante a/mediante de function as prepositional phrases and not as stand-alone prepositions.

24 In Sánchez López (2014, pp. 415-16), a cross with por medio de is proposed as a possible explanation for the existence of mediante de. 
"As far as Cardoso is concerned, he is a very honest young man and, given his good sense, I have done with him what he asked me since he told me that he loved Your Worship very much."

But maybe the most conclusive proof of the prepositional nature of mediante from its very first documentation is found in the example of the translation of De re rustica, also known as Opus agriculturae, by Ferrer Sayol, quoted earlier. The example is repeated below (14'). It is signifiant that this early example of Ferrer Sayol translates the Latin preposition per 'by, with' by mediante (see 31 for the Latin example). That is to say, Ferrer Sayol resorts to mediante as an alternative to per, whose prepositional value in Latin is beyond doubt and whose parallelism with Spanish por 'by' could have favored the use of this preposition instead of the innovative mediante.

$\left(14^{\prime}\right)$ Otra manera ay de fazer vjñyas es a saber que hombre ha muchas cañyas al derredor de la parra o de la çepa. E ata hombre los sarmjentos a cada vna cañya al entorno. E los vnos sarmjentos se ligan con los otros mediante las cañyas. (Ferrer Sayol, Libro de Palladio, 1380-1385, CORDE)

"There is another way of making vines, namely that you put many canes around the vine or the stock. And you must tie the shoots around each cane. And some shoots are linked with the others through the canes."

(31) aliud genus est in quo cannis pluribus circa dispositis ipsa uitis per cannas sarmentis ligatis in orbiculos flectitur se sequentes. (Palladius Rutilius Taurus Aemilianus, Opus agriculturae (LLA 603)_LLT-B lib.: 3, cap.: 11, pag.: 78, linea: 2, Brepolis.

"There is another procedure in which the vine itself, with several canes places around it, and with the shoots intertwined by means of the canes, twist in successive circles."

In view of the above, it does not seem possible to defend the idea of an evolutionary path for mediante leading from a present participle used in an absolute clause to a preposition. The data we have available reflect its clearly grammatical use from its beginnings. The few examples that could fall under the rubric of an absolute ablative structure can be understood as the result of a Latinizing trend, which was in decline from the end of the fifteenth century. In this way, in the sixteenth century, constructions in which a nominal element is placed before mediante are practically reduced to the lexicalized expression Dios mediante 'with the help of God', which already alternates with the alternative mediante Dios (32). In this century, the use of the plural of mediante diminishes drastically. In fact, although the possibility of a plural agreement persists until the twentieth century, it is a stereotypical formulation which is not really productive in the language. Thus, the most recent examples in our corpora appear under the lexicalized expressions mediantes las oraciones 'through the prayers' (33) and Dios y la justicia mediantes 'with the help of God and justice' (34). In both cases, mediante has a prepositional value.

(32) e mediante Dios llegarés en buena disposición (Fernando de la Torre, Libro de las veynte cartas e quistiones, c1449, CORDE)

"And you will arrive in good in good order."

(33) Andamos padre mio en esta machina de negoçio tan grande en sy y en los muchos negocios que dependen del; alumbre su divyna Magestad al Rey nuestro Señor y a sus ministros para que en todo se acierte a hacer su santa voluntad, como lo confio en su misericordia mediantes las oraçiones de Vuestra R. (Pascual Boronat \& Barrachina, Los moriscos españoles y su expulsión, 1901, CORDE)

"We are engaged, Father, in this business which is so great in itself, and in the many matters which depend on it; may His Divine Majesty enlighten our Lord the king and his ministers so that in everything His holy will may be done, as I trust in His mercy, through the prayers of Your Reverence." 
(34) Dios y la justicia mediantes han de coger a los bandidos, (Tomás Carrasquilla, La marquesa de Yolombó, 1928, CORDE)

"With the help of God and justice, they will catch the bandits."

\section{The Influence of Culture on the Evolution of Languages. Grammatical Borrowings}

At this point, it is important to return to the hypothesis of the grammatical calque that I have focused on in this work as a possible explanation for the existence of mediante in Spanish. In fact, the first documentation of mediante in Old Spanish in the fourteenth century are from the work of the Aragonese Juan Fernández de Heredia and the Catalan Ferrer Sayol, as well as from two other texts, also written in the Kingdom of Aragon, namely, Memoria de las labranzas and the Gestas del rey don Jayme de Aragón. Therefore, the recourse to mediante may have to do with the influence of the author's mother tongue and culture (Catalan and Aragonese). Indeed, when commenting on Villena's profuse use of the present participle in this work, Pons Rodríguez (2015) points out the following:

Como elemento impulsor de esta característica de su usus scribendi, además del peso del latín, no se puede descartar el que este rasgo fuera propio de la lengua aragonesa, que tan afín le resultaba. (Pons Rodríguez 2015, p. 406)

"As a driving force of this characteristic of his usus scribendi, in addition to the weight of Latin, it cannot be ruled out that this trait was characteristic of the Aragonese language, which was so similar to it". [my translation]

This influence of the linguistic varieties of the eastern part of the Peninsula on medieval and Renaissance Spanish has been observed in other areas of its grammar; for example, the extension of the lack of number and gender inflection in the participle of the compound tenses (Fernández-Ordóñez 2011; Rodríguez Molina 2010), in the evolution of certain locative expressions, and of particular prepositions and conjunctions (Octavio de Toledo y Huerta 2016; Ridruejo 1984), as well as the use of the indicative future in counterfactual subordinate clauses (Ridruejo 1984).

However, it should not be forgotten that the presence of the present participle in Catalan and Aragonese could also be the result of a learned borrowing introduced at the end of the Middle Ages. Indeed, Campos Souto (2001, p. 373) and Mesa Sanz (2004) point out that present participles in the vernacular language do not constitute patrimonial forms. Specifically, Mesa Sanz (2004, p. 371) considers the existence of the present participle in Romance languages to be the result of the rhetorical artifice of the medieval language so that no Romance language inherits it directly from Latin. ${ }^{25}$ However, whatever the origin of the use of present participles in the linguistic varieties of the eastern part of the Peninsula, the imprint of Catalan and Aragonese on the Spanish language cannot be ignored, either as importers of linguistic novelties or as the origin of innovations ${ }^{26}$ (Fernández-Ordóñez 2011; Octavio de Toledo y Huerta 2017a; Pons Rodríguez 2015; Ridruejo 1984; Rodríguez Molina 2010). In the specific case of mediante, Aragonese or Catalan authors are the first to use this grammatical form in

25 According to Bassols de Climent (1992, p. 234):

Si bien en el período clásico tiene [el participio de presente] un significado acusadamente verbal en cuanto expresaba acciones (como los verbos) y no cualidades (como los adjetivos), no obstante ya en el latín arcaico y popular va ganando terreno su valor nominal sobre el verbal. Triunfa esta tendencia en romance (...).

While in the classical period, [the present participle] has a markedly verbal meaning insofar as it expressed actions (like verbs) and not qualities (like adjectives), in archaic and popular Latin, its nominal value steadily gains ground over the verb. This trend prevails in Romance ( . . . )'.

[my translation]

26 An identical influence is observed in the emergence of no obstante, no embargante, and no contrastante (cf. Garachana Camarero 2018). And the same can be said of the preposition durante. 
their works written in Spanish, so it is safe to assume that Aragonese and Catalan would have served as catalysts for the introduction of a Latinizing structure in Spanish that would not triumph, in general, but would leave its mark on the preposition mediante. ${ }^{27}$

In dealing with the influences of eastern linguistic varieties on the introduction of learned (Latin) linguistic traits in Old Spanish, Octavio de Toledo y Huerta (2017a, p. 82) points out that key authors from the fourteenth century were trained in Italy or in Catalonia and Aragon: Villena, Mena, Santillana, Martínez de Toledo, or Alfonso de la Torre, among others. It is also important to point out, following Octavio de Toledo y Huerta (2017a), that the Latinisms introduced in the Romance languages at this time arrived via translations of legal, administrative, or technical texts so that there is no diglossic situation that might have inhibited their extension into the vernacular language. On the contrary, they are what Barra Jover (2010, p. 64) called "unmarked Latinisms", which, since they were not introduced into the language through prestigious variants, but through everyday communicative situations among speakers, can be consolidated more easily into the language.

Present participle constructions re-analyzed as prepositions constituted a rhetorical fashion on the rise at this point in Western European history. This is evidenced by the fact that similar structures exist in other Western European languages. In the specific case of mediante, there are synonymous forms in Catalan mediant (35), French moyennant (36), or Italian mediante (37), whose first documentations are close in time to those of Spanish (all seem to be concentrated in the fourteenth century).

(35) speram en Nostre Senyor Déu, mediant lo seu divinal auxili, partir de ací lo terç jorn de festes de Nadal (Lletres reials a la ciutat de Girona, 1293, II-6, Carta 627, linia: 18, CICA)

"we hope in our Lord God, through his divine help, to leave from here the third day of the Christmas festival."

(36) ... moiennant les prieres de l'eglise (JEAN GOLEIN, Rational B.D., c.1370-1372, p. 679). [Traité du sacre, DMF]

"thanks to the prayers of the church."

(37) E mediante la grazia di Dio tutti gli altri guarirono (Simone Sigoli, Viaggio al monte Sinai, TLIo)

"And by the grace of God, all the others will be healed."

In addition to mediante (and durante), Spanish, Catalan, Aragonese, French, and Italian also employ no obstante and no contrastante 'although'. Moreover, Spanish and Aragonese also used no embargante 'in spite of, although, however', which, like no obstante, was used as a preposition, a conjunction and a counter-argumentative discourse marker (cf. Garachana Camarero 2018; Pérez Saldanya and Salvador 2014). All of these forms are Latinisms, which were disseminated in European languages from the fourteenth century. Consequently, attention should be drawn to the importance of not misidentifying grammatical change as grammaticalization. In fact, the data provided by the texts do allow us to explain the introduction of mediante into Spanish as a result of a grammatical calque that, coming from the east of the Peninsula, triumphed in Spanish, while it was lost in Catalan. What was the origin of the misunderstanding? It seems to be the wide explanatory power of the Theory of Grammaticalization, which can sometimes make it possible to explain on the basis of this approach processes of change that respond to other evolutionary mechanisms, such as the grammatical calque (for this question cf.

27 An identical influence is observed in the emergence of no obstante, no embargante, and no contrastante (cf. Removed for peer review.). The same can be said for the preposition durante.

This idea, applied to the present participle, in general, is already found in Ridruejo (1984). On the other hand, Lapesa (1986) and Meilán García (1991) point out a possible influence of French for the use of present participles, in general, in Old Spanish. 
Harris and Campbell 1995). It is, therefore, necessary to pay attention to the data and not to ignore the socio-cultural factors in which the language is set and which, therefore, can be decisive in its history.

\section{And after the Calque ... Grammaticalization?}

In the previous pages, I have argued that the existence of mediante in Spanish is not the result of a grammaticalization process. Nonetheless, from the preposition mediante, the conjunction mediante que 'because' was later developed, the existence of which could perhaps be explained as a case of secondary grammaticalization. ${ }^{28}$ However, the concept of secondary grammaticalization itself is not well outlined in grammatical theory and is entangled in a theoretical discussion which is yet to be resolved. If we add to this the fact that the existence of mediante que can be argued to be the result of the broadening of the scope of the preposition mediante by coming to encompass a whole clause, we can explain the emergence of mediante que as an analogical expansion which was favored by the re-analysis of mediante. Consequently, it is also possible to explain the existence of mediante que without resorting to the theory of grammaticalization. ${ }^{29}$ As I will demonstrate in the following paragraphs, the process follows paths of change in which analogy is key.

The consolidation of mediante in Spanish, which, as was stated, became evident in the attempt to adapt it paradigmatically to the language through combinations with other prepositions that would turn it into a prepositional locution, also led to further enlargement of its scope. Thus, from the sixteenth century onwards, we begin to find instances of mediante governing verbal infinitives and complement clauses. This is the beginning of the process of formation of the conjunction mediante que. As shown in (38), the prepositional use of mediante before nominal elements allowed its analogical extension in contexts in which this nominal element was an infinitive, which at times, in spite of being preceded by an article, had a verbal value (see examples in 39, and especially Sánchez López 2016). From these constructions, an additional analogical extension of mediante emerged when it started to be employed before complement clauses headed by que. From here, there was a re-analysis of mediante and que as causal conjunction. At this point, as pointed out by Sánchez López (2016), mediante loses its traits of semantic selection, as it goes from governing terms that denote entities that can be interpreted as instruments to governing sentences (40).

(38) $[\mathrm{pP}[$ prep Mediante $[\mathrm{NP}]]>[\mathrm{pP}[\mathrm{prep}$ Mediante $[\mathrm{INF}]]>[\mathrm{pP}[\mathrm{prep}$ Mediante $[\mathrm{QuE}+$ CLAUSE $]]>$ [Causal sentence [causal conj. Mediante que [Clause]]

(39) a. Todos estos indios destas prouinçias referidas ( . . ) es gente que vsan y acostumbran poner en las flechas hierba ponzoñosa y pestilençial, con que matan la gente ( . . ) y mediante el vsar desta hierua pestilençial para su defensa, se conseruan y an defendido siempre de los españoles, y nunca an sido enteramente subiectos, ni domados dellos. (Fray Pedro de Aguado, Historia de Santa Marta y Nuevo Reino de Granada, 1573-1581, CORDE)

"All these Indians of the aforementioned provinces are people who usually put on the arrows a poisonous and pestilent herb with which they kill people, and, through using this stinking herb for their defense, they keep and have always defended themselves from the Spaniards, and they have never been completely subdued or controlled by them."

b. paresciole a Yamque Yupangue que su padre era ya de gran edad y que mediante andar ellos en la guerra sería posible morir y no hallarse ellos a su muerte (Juan de Betanzos, Suma y narración de los incas, 1551, CORDE)

28 The concept of secondary grammaticalization was coined by Givón (1991) to refer to the second type of change that Kuryłowicz (1965) proposed in his definition of grammaticalization, namely, a change that leads from grammatical elements to more grammatical ones. Later, Traugott (2002) created the notion of primary grammaticalization to allude to the evolutive steps that lead from the lexical to the grammatical. For a review of the concept of secondary grammaticalization, cf. Winter-Froemel (2014).

29 The most detailed study on the creation of mediante que is that of Sánchez López (2016). 
"It seemed to Yamque Yupangue that his father was very old and that, since they were at war, he could die and they would no be present when he died."

(40) Los papeles periodicos no dan a sus autores menos derecho; pues el producir sus noticias en esta forma no es efecto de corta literatura, sino de haver imaginado, que combenia propagar asi las noticias, mediante que se facilita la lectura de mayor numero de personas. (Juan Antonio Llorente, Discursos sobre el orden de procesar en los tribunales de Inquisición, 1797, CORDE)

"Periodical publications do not give their authors less right; for producing their news in this way is not the consequence of bad literature, but of their having imagined that it was appropriate to publish news in this way since it made it easier for a greater number of people to read it."

The causal meaning of mediante que is explained by the fact that this sense was already one of its prepositional values. That is, the sense of mediation and of a means by which an action is carried out or a state is reached evolve into causation: carrying out an action by way of someone or something allows for the inference that such thing is done thanks to it, that is, because of it. In the prepositional uses, the sense of causation must be understood as a positive cause. In the conjunctive uses, this causal sense was established in the expression of the explanatory or justifying cause, which, as Sánchez López (2016) points out, is the characteristic value of the sentences headed by mediante que.

\section{Conclusions}

In this paper, I have reflected on the introduction of the preposition mediante in Spanish. Traditionally, its emergence in the language has been described as a process of grammaticalization. However, a detailed analysis of the data shows us, from its very first documentation, examples in which mediante appears well established as a preposition (in fact, it already existed in Latin). The constructions in which mediante has a verbal value in Old Spanish are the result of the Latinizing trends of the (pre)Renaissance, which, in spite of the positive appraisal of vernacular languages, exalted Latin to the extent of generating syntactic structures that violated the grammar of these languages. Hybrid constructions in which mediante appeared with plural morphology-impossible for Spanish prepositions, which are never inflected-can not be considered in most cases as verbal uses of mediante. In fact, in almost all cases, despite its plural form, mediante is a grammatical particle with a prepositional function.

Considering the difficulty of explaining the existence of mediante as the result of a process of grammaticalization, an alternative explanation is preferred based on the detailed analysis of the examples obtained from CORDE and the GRADIA corpora. This study has shown that the first examples of mediante are documented in texts written by Aragonese and Catalan authors. Something similar happens with other prepositions, conjunctions, and discourse markers originating in early present participles, namely, durante 'during', no obstante, no embargante 'in spite of, although, however', and no contrastante 'in spite of, although'. Moreover, these constructions have been documented in the languages of Western Europe since the fourteenth century with similar values. Consequently, the hypothesis can be ventured that they consist of a grammatical borrowing from Latin that spread through the European languages and reached Old Spanish through the Crown of Aragon, or, more specifically, through Aragonese and Catalan.

The triumph of mediante as a preposition probably has much to do with the exceptional character of present participles in Spanish, which would have favored the primacy of prepositional values, which did not violate the syntactic rules of Spanish where the present participle is not a grammatical class. However, as has already been pointed out, the prepositions coming from participles have a form and meaning that are not particularly consistent with a class of words characterized by their low semantic load and limited phonetic length. Quite possibly, for this reason, examples soon began to be documented in which de was placed after the preposition, and more rarely, $a$, in clear parallelism with what happened with no embargante de, no obstante de, and no contrastante de 'in spite 
of $^{\prime}{ }^{30}$ The postposing of a preposition constitutes a grammatical redundancy, given that mediante, durante, no embargante, no obstante, and no contrastante were already prepositions. Then, how does one explain this redundancy? The answer is that the use of the prepositions $a$ and de following mediante, durante, no obstante, no embargante, and no contrastante was an attempt to formally integrate these forms derived from a participle into the paradigm of prepositions. This highlights the importance of analogy in speakers' linguistic behavior, as they often try to standardize grammatical paradigms on the basis of the functional or semantic resemblance they perceive between linguistic forms.

Finally, once the prepositional form was established in the language, the causal conjunction mediante que was created, which was used in Spanish from the sixteenth to the nineteenth century. The formation of the conjunction mediante que from the preposition mediante suggests its re-analysis in contexts in which mediante does not govern a phrase, but rather a sentence. Mediante que is an extension of the prepositional use of mediante motivated by the analogical extension of the type of complement it appears next to. In the same way that por or para can be followed by a nominal element, an infinitive verb, or a sentence, mediante started out governing nominal phrases and ended up governing clauses as well. The process would have been facilitated by the use of mediante before infinitives. This functional change was accompanied by the consolidation of explanatory or justifiable causal meanings of mediante $q u e$, which did not become established in the language.

\section{Main Corpus}

BrePolis $=$ Brepolis Library of Latin Texts Series A-B, Turnhout, Brepols (apps.brepolis.net). CICA $=$ Corpus informatitzat del català antic (http://www.cica.cat).

CORDE $=$ Real Academia Española, Banco de datos (CORDE) [en línea]. Corpus diacrónico del español . $<$ http://www.rae.es> [Enero de 2015].

CORPES XXI = Real Academia Española, Banco de datos CORPES XXI [en línea]. Corpus del Español del Siglo XXI, <http://web.frl.es/CORPES/view/inicioExterno.view> [consulta junio 2016].

DMF $=$ Centre National de la Recherche Scientifique/Université de Lorraine (2015): Dictionnaire du Moyen Français [online], <http://www.atilf.fr/dmf>.

GRADIA $=$ Corpus de Gramática y diacronía (gradiadiacronia.wix.com/gradia).

TLIO $=$ Corpus testuale dell'Italiano antico (http://www.ovi.cnr.it/).

Funding: This research received no external funding.

Acknowledgments: I would like to thank Esther Artigas for her help with the Latin basis of this research; I would also like to thank Álvaro Octavio de Toledo for his attentive reading of this work and the many suggestions he made. I also express my thanks for the comments of anonymous reviewers. Finally, I must thank Christopher Pountain for his invaluable help with the English translation. Errors and inaccuracies are, however, entirely my responsibility.

Conflicts of Interest: The author declares no conflict of interest.

\section{References}

Azofra Sierra, Elena. 2006. Problemas de sintaxis y traducción: El caso del participio de presente en español. Epos 22: 67-80. [CrossRef]

Barra Jover, Mario. 2010. Cómo vive una Lengua "muerta": El peso del Latín Medieval en la evolución romance. In Modelos Latinos en la Castilla Medieval. Edited by Mónica Castillo Lluch and Marta López Izquierdo. Madrid and Frankfurt am Main: Iberoamericana \& Vervuert, pp. 63-79.

30 Cuervo, in his note 143 on Bello's Gramática, points out the use of prepositions durante, mediante, obstante, embargante, excepto followed by $a$ or de, as a result of the analogy with synonymous locutions, such as a pesar de, sin embargo de. For Cuervo, these are objectionable constructions which he qualifies as carelessness that "deben evitarse a todo trance" ('should be avoided at all costs', Cuervo note 143 in Bello 1988, pp. 969-70. My translation). 
Bassols de Climent, Mariano. 1992. Sintaxis de la Lengua Latina. Madrid: Consejo Superior de Investigaciones Científicas.

Bello, Andrés. 1988. Gramática Castellana Destinada al uso de Los Americanos. Madrid: Arco Libros. First published 1847.

Berg, Thomas. 1998. Linguistic Structure and Change: An Explanation from Language Processing. Oxford: Clarendon Press.

Bosque, Ignacio. 1989. Las Categorías Gramaticales: Relaciones y Diferencias. Madrid: Síntesis.

Campos Souto, Mar. 2001. So la sonbra de los Árvoles Fazientes Verano: El participio de presente en una traducción castellana cuatrocentista. Moenia 7: 371-91.

Castro Zapata, Isabel M. 2010. El camino hacia la preposición. Los procesos de gramaticalización de durante y mediante. Interlingüística 20: 1-11.

Castro Zapata, Isabel M. 2012. Del participio a la preposición. Procesos de gramaticalización de 'durante' y 'mediante'. Paper presented at Actas del VIII Congreso Internacional de Historia de la Lengua Española, Santiago de Compostela, Spain, 14-18 September 2009; Edited by Emilio Montero Cartelle and Carmen Manzano Rovira. Santiago de Compostela: Meubook, vol. 1, pp. 721-33.

Company, Company, and Concepción, eds. 1997. Prototipos y el origen marginal de los cambios lingüísticos. El caso de las categorías del español. In Cambios Diacrónicos en el Español. Mexico: Universidad Nacional Autónoma de México, pp. 143-68.

Cornillie, Bert, and Bridget Drinka. forthcoming. Latin Influence on the Syntax of the Languages of Europe. Belgian Journal of Linguistics.

Cornillie, Bert, and Álvaro S. Octavio de Toledo y Huerta. 2015. The Diachrony of Subjective Amenazar 'threaten'. In New Directions in Grammaticalization Research. Edited by Andrew D. M. Smith, Graeme Trousdale and Richard Waltereit. Amsterdam and Philadelphia: John Benjamins, pp. 187-208.

de Granda, Germán. 1979. Calcos sintácticos del guaraní en el español del Paraguay. Nueva Revista de Filología Hispánica 28: 267-87. [CrossRef]

Espinosa Elorza, Rosa M. 2010. Procesos de Formación y Cambio en las Llamadas "Palabras Gramaticales". San Millán de la Cogolla: Cilengua.

Fernández Alcaide, Marta. 2009. Cartas Privadas de Españoles en el Nuevo Mundo (S. XVI). Madrid and Frankfurt: Iberoamericana \& Vervuert.

Fernández-Ordóñez, Inés. 2011. La Lengua de Castilla y la Formación del Español. Madrid: Real Academia Española.

Fisher, Olga. 2011. Grammaticalization as Analogically Driven Change? In The Oxford Handbook of Grammaticalization. Edited by Heiko Narrog and Bernd Heine. Oxford: Oxford University Press, pp. 31-42.

Garachana Camarero, Mar. 2018. New Challenges in Theory of Grammaticalization. Evidences from the Rise of Spanish Counterargumentative Markers No Obstante, No Contrastante and No Embargante. In Beyond Grammaticalization and Discourse Markers. New Issues in the Study of Language Change. Edited by Salvador Pons Bordería and Óscar Loureda Lamas. Leiden: Brill, pp. 198-230.

Giacalone Ramat, Anna. 1994. Fonti Di Grammaticalizzazione. Sulla Ricategorizzazione Di Verbi E Nomi Come Preposizioni. In Miscellanea di Studi Linguistici in Onore di Walter Belardi. Edited by Walter Belardi, Palmira Cipriano, Paolo Di Giovine and Marco Mancini. Roma: Il Calamo, pp. 877-96.

Givón, Talmy. 1991. The Evolution of Dependent Clause Morpho-Syntax in Biblical Hebrew. In Approaches to Grammaticalization: Types of Grammatical Markers. Edited by Elizabeth Closs Traugott and Bernd Heine. Amsterdam and Philadelphia: John Benjamins, vol. 2, pp. 257-310.

Harris, Alice C., and Lyle Campbell. 1995. Historical Syntax in Cross-Linguistic Perspective. Cambridge: Cambridge University Press.

Haspelmath, Martin. 2001. The European Linguistic Area: Standard Average European. In Language Typology and Change. Edited by Martin Haspelmath, Ekkehard König, Wulf Oesterreicher and Wolfgang Raible. Berlin: Walter de Gruyter, pp. 1492-510.

Heine, Bernd, and Tania Kuteva. 2006. The Changing Languages of Europe. Oxford: Oxford Europe Press.

König, Ekkehard, and Bernd Kortmann. 1991. On the Reanalysis of Verbs as Prepositions. In Approaches to Prepositions. Edited by Gisa Rauh. Tübingen: Narr, pp. 109-25.

Kortmann, Bernd. 1992. Reanalysis Completed and in Progress: Participles as Source of Prepositions and Conjunctions. In Diachrony within Synchrony. Language History and Cognition. Edited by Günter Kellermann and Michael D. Morrissey. Frankfurt am Main: Lang, pp. 429-53. 
Kuryłowicz, Jerzy. 1965. The Evolution of Grammatical Categories. Diogenes 55: 55-71. [CrossRef]

Lapesa, Rafael. 1986. Historia de La Lengua Española. Madrid: Gredos.

Meilán García, Antonio José. 1991. El comportamiento funcional del 'participio de Presente' en el castellano medieval y renacentista. Revista de Filología de la Universidad de La Laguna 10: 281-98.

Mesa Sanz, Juan Francisco. 2004. Participio de presente latino tardío y medieval: entre norma y habla. ELUA: Estudios de Lingüística. Anexo 2: 363-79. [CrossRef]

Moliner, María. 1966. Diccionario de uso del Español. Madrid: Gredos.

Muñío Valverde, José L. 1995. Pervivencia del participio de presente activo en el español antiguo. Romanistisches Jahrbuch 46: 231-50. [CrossRef]

Octavio de Toledo y Huerta, Álvaro S. 2016. Los Relacionantes Locativos en la Historia del Español. Berlin: Mouton de Gruyter.

Octavio de Toledo y Huerta, Álvaro S. 2017a. Juan de Mena como traductor: Aspectos lingüísticos del Omero Romançado. In Romanische Sprachgeschichte und Übersetzung. Edited by Heidi Aschenberg and Sarah Dessì Schmid. Heidelberg: Winter, pp. 53-113.

Octavio de Toledo y Huerta, Álvaro S. 2017b. El pretérito perfecto de subjuntivo en la Edad Media: Distribución dialectal, entornos sintácticos y tradicionalidad discursiva. Moenia 23: 317-66.

Pascual, José Ignacio. 2016. La Filología en vago y en vilo entre los datos. In Grandes y Pequeños de la Literatura Medieval y Renacentista. Edited by Medieval Y. Blanco. Salamanca: Seminario de Estudios Medievales y Renacentistas, pp. 55-84.

Pavón Lucero, María V. 1999. Clases de partículas: Preposición, conjunción y adverbio. In Gramática Descriptiva de la Lengua Española. Edited by Ignacio Bosque and Violeta Demonte. Madrid: Espasa Calpe, pp. 565-655.

Pavón Lucero, María V. 2010. Why Are There No Locative Conjunctions in Spanish? Catalan Working Papers in Linguistics 9: 103-23. [CrossRef]

Pérez Saldanya, Manuel, and Vicent Salvador. 2014. Oraciones concesivas. In Sintaxis Histórica de la Lengua Española. Tercera Parte: Adverbios, Preposiciones y Conjunciones. Relaciones Interoracionales. Edited by Company Company and Concepción. Mexico: Fondo de Cultura Económica \& Universidad Nacional Autónoma de México, vol. 3, pp. 3697-839.

Pons Rodríguez, Lola. 2015. La Lengua Del Cuatrocientos Más Allá de Las Trescientas. In Actas del IX Congreso Internacional de Historia de la Lengua Española. Edited by José María García Martín, Teresa Bastardín Candón and Manuel Rivas Zancarrón. Madrid and Frankfurt am Main: Iberoamericana \& Vervuert, vol. 1, pp. 393-430.

Pueyo, F. Javier, and Andrés Enrique-Arias. 2015. Innovación y tradición en el léxico de las traducciones bíblicas castellanas medievales: El uso de cultismos y voces patrimoniales en las versiones del siglo XV. Anuario de Estudios Medievales 45: 357-92. [CrossRef]

RAE-ASAle. 2009. Nueva Gramática de La Lengua Española. Madrid: Espasa.

Ridruejo, Emilio. 1984. Tres catalanismos (y aragonesismos) sintácticos en Los Doze Trabajos de Hércules del Marqués de Villena. Archivo de Filología Aragonesa 34-35: 273-90.

Rodríguez Molina, Javier. 2010. La Gramaticalización de los Tiempos Compuestos en Español Antiguo: Cinco Cambios Diacrónicos. Madrid: Universidad Autónoma de Madrid.

Rodríguez Molina, Javier, and Álvaro S. Octavio de Toledo y Huerta. 2017. La imprescindible distinción ente texto y testimonio: El CORDE y los criterios de fiabilidad lingüística. Scriptum Digital 6: 5-68.

Sánchez Lancis, Carlos. 2001. La Gramaticalización de los participios latinos de presente 'durante' y 'mediante' a través de las gramáticas y los diccionarios del español. Anuari de Filologia. Secció F, Estudios de Lengua y Literatura Españolas 11-12: 95-110.

Sánchez López, Cristina. 2014. Preposiciones, conjunciones y adverbios derivados de participios. In Sintaxis Histórica de la Lengua Española. Tercera Parte: Adverbios, Preposiciones y Conjunciones. Relaciones Interoracionales. Edited by Company Company. Mexico: Fondo de Cultura Económica \& Universidad Nacional Autónoma de México, vol. 3, pp. 2055-177.

Sánchez López, Cristina. 2016. Cuando la gramaticalización se detiene: El caso de durante que y mediante que. In Las Relaciones Interoracionales en Español. Categorías LingüÍsticas y Subordinación Adverbial. Edited by María Victoria Pavón Lucero. Berlin: De Gruyter, pp. 123-60. 
Traugott, Elizabeth Closs. 2002. From Etymology to Historical Pragmatics. In Studies in the History of the English Language. Edited by Minkova Donka and Robert Stockwell. Berlin: Mouton de Gruyter, pp. 19-49.

Winter-Froemel, Esme. 2014. Re(de) Ning Grammaticalization from a Usage-Based Perspective Discursive Ambiguity in Innovation Scenarios. Folia Linguistica 48: 503-56. [CrossRef]

(c) (1)

(C) 2019 by the author. Licensee MDPI, Basel, Switzerland. This article is an open access article distributed under the terms and conditions of the Creative Commons Attribution (CC BY) license (http://creativecommons.org/licenses/by/4.0/). 
Article

\title{
The Role of Elision in Evolutionary Processes
}

\author{
María Elena Azofra Sierra \\ Departamento de Lengua Española y Lingüística General, Facultad de Filología, Universidad Nacional de \\ Educación a Distancia (UNED), E-28040 Madrid, Spain; eazofra@flog.uned.es
}

Received: 21 December 2018; Accepted: 11 February 2019; Published: 17 February 2019

\begin{abstract}
Changes by elision-as well as those due to processes of adfunctionalization or refunctionalization-must be taken into account as explanatory mechanisms of linguistic change. In this paper, we study the role of elision in the theoretical overview of explanatory theories of language change by focusing on the evolutionary process of the Spanish adverb aparte. We analyze the consequences of the elision of an initial construction for the development of new functions as an exceptive or additive adverb, and as an additive connector with a specific meaning, conditioned by the evolution of the entire construction. We find that, in this case, the ellipsis of a verbal element has led to important modifications of the preserved item (aparte), not only at the semantic-pragmatic and functional levels but also in its category membership.
\end{abstract}

Keywords: elision; connector; construction; evolutionary process

\section{Objective and Hypothesis}

The objective of this paper is to analyze the role played by elision in processes of grammatical evolution on the basis of the data provided by the changes undergone by of the particle aparte in the course of its history. ${ }^{1}$ The cases analyzed in texts from the 15th century onwards indicate that the functions that aparte acquired from the 16th century, first as an exceptive particle, and later on as an 'adlative' additive connector, have their origin in the integration of the adverb in certain absolute constructions which were widespread in the 16th century (dejando aparte, dejado aparte ... ), and which underwent the elision of the verb dejar 'to leave'. Thus, the adverb aparte was pragmatically loaded with the meaning of the entire construction and experienced a major functional change when reanalyzed as an exceptive particle.

In other words, the history of aparte allows us to analyze to what extent a verbal elision constitutes the point of departure for a process of change that cannot be entirely explained by the Theory of Grammaticalization, and that has as its main consequence the semantic and functional complexity of aparte. As we will see, in current Spanish aparte works not only as an adverb of place-directional or locative (1a, 1b) —or as an adverb of manner (1c), but also as a noun (1d), as an adjective (1e), as an exceptive adverb (1f), as an additive adverb (1g), and as additive connector of specific meaning, which we have labeled an 'adlative additive' (Azofra Sierra 2014) (1h). ${ }^{2}$ As an exceptive and an additive, it admits prepositional or conjunctive extension (aparte de/[de] que).

(1) a. Llevaron aparte ('a otro lugar') al detenido. "The person under arrest was taken aside." b. Enterraron el cuerpo aparte ('en otro lugar'). "The body was buried apart." c. Las invasiones se organizaron aparte ('separadamente, de forma independiente'). "Invasions were organised

1 I would like to express my gratitude to the anonymous reviewers for their helpful comments on an earlier version of this paper. Oversights, omissions, and errors in the final version of the paper are entirely my own.

2 According to the RAE and ASALE $(2009,1.9 \mathrm{z})$, connectors or markers are a "discursive class" that can be formed by adverbs, prepositions, conjunctions or more complex constructions. 
separately." d. La relación de los personajes se descubrió en un aparte ('una conversación privada, que no oyen otras personas'). "Relationships between the characters were unveiled in an aside." e. Cervantes es un escritor aparte ('diferente'). "Cervantes is a writer apart" f. \{Aparte del precio / El precio aparte\} ('excepto el precio'), es una compra estupenda. "Its price apart, it's an excellent buy." g. Aparte de guapa ('además de guapa'), es muy buena persona. "Apart from being beautiful, she's a good person." h. No tiene ningún motivo para lamentarse: aparte de que ('además de que') tiene una familia estupenda, su trabajo es interesante y le permite disfrutar de una buena renta. "She has no reason to complain. Besides having a wonderful family, her job is interesting and allows her to enjoy a good income."

From the theoretical point of view, the explanatory scope of the Theory of Grammaticalization, especially in the case of the evolution of discourse markers, has been long questioned (cf. Company 2004; Garachana Camarero 2015; Pons Rodríguez 2010, for more in-depth analysis). In fact, not all changes can be explained by grammaticalization; that is to say:

[T] he change whereby lexical items and constructions come in certain linguistic contexts to serve grammatical functions, and, once grammaticalized, continue to develop new grammatical functions. (Hopper and Traugott [1993] 2003, p. 18)

We believe that the evolutionary process of the particle aparte will allow us to analyze where to set elision within the theoretical overview of explanatory theories of language change. Finally, it is important to underline the fact that context as a locus of change comes to have changes by elision: Forms do not change in isolation, but they acquire new functions depending on their context and are-as we will see in this case-integrated into a given construction. It is, therefore, necessary to emphasize the importance of constructionalization (Traugott and Trousdale 2013). The result is a particle that acquires new functions in the course of its history while not losing the initial meanings linked to the locative adverbial category, in a process that could be defined as 'adfunctionalization' according to Smith (2011, p. 305): "The process in which a form assumes a new function alongside or in addition to its original function."

\section{The History of the Particle Aparte}

\subsection{Grammaticalization}

Originally, aparte comes from a locative prepositional phrase that has been grammaticalized as an adverb, a \{una/otra/su\} parte > aparte (for a detailed analysis of the history of the particle aparte, cf. Azofra Sierra 2011). The original phrase, of which we have examples in (2), inherits a Latin construction with the preposition AD, whose meaning can be directional ('hacia, a') or situational ('junto a') depending on the context. From a theoretical point of view, the process that gives rise to the adverb of place can be explained in terms of grammaticalization: The original noun fails to admit determiners or complement phrases (2); it loses the possibility of number inflection, and the construction is blended as one single item, fixed as early as the medieval times: Invariable, and characteristically adverbial, either locative 'a/en otro lugar', 'a distancia' (3) or modal 'separadamente' (4).

(2) que se tiró a una parte por le dar el viento (c. 1300-1325, Cuento muy famoso de Otas de Roma). "he stepped aside to avoid the gale" b. que los freyres posauan a su parte (1293, Gran Conquista de Ultramar). "that the friars put at their side" c. e el uno, echado a otra parte medio vivo, mostraba razón de la muerte (a 1280, Alfonso X, General Estoria). "and one, lying aside half alive, showed signs of death"

(3) a. Essora salién aparte ifantes de Carrión (c. 1140, Poema de Mio Cid). "Then the princes of Carrión stood aside" b. E de los çient cavalleros, llamó los veynte a parte delos mejores (c 1300-1325, Cuento muy fermoso de Otas de Roma). "And from the one hundred knights, he called aside twenty of the best" 
(4) Et si el bozero o el duenno del pleito quisiere aver consejo, que lo aya a parte; (1252, Documentos notariales). "And if the lawyer or the litigant should wish to deliberate, let them do so apart;"

In these examples, the original function-both of the prepositional construction $a\{u n a /$ la $/$ otra/su\} parte and the adverb aparte - is an adjunct of the verb, indicating a locative circumstance. As indicated by RAE and ASALE (2009, 30.2n), most adverbs in Spanish are adjuncts, that is, unselected modifiers. However, on the other hand, we find instances of the adverb aparte as a noun complement from the earliest texts on-probably after verbal ellipsis-constructions of the capitulo aparte type, which were frequent in legal texts. ${ }^{3}$ From the 15 th century on, this construction increases and spreads to other contexts, until it generalizes in a variety of genres in the 17 th century (reino aparte, conversación aparte...), see example (5):

(5) Él fundó a Roma en el monte Aventino e fizo regno aparte para sí (1427-1428, E. de Villena, Traducción y glosas de la Eneida) "He founded Rome on the Mount Aventine and made a separate kingdom for himself"

Very much to the Latinizing taste of the age, an absolute construction became frequent in the 15th century, in which aparte was combined with the gerund or past participle of the verbs dejar or poner, with the meaning 'to omit' or 'to ignore', as illustrated in (6), (7) and (8):

(6) Atreviéndose, todo temor aparte puesto, contra las defensiones legales (1427-1428, E. de Villena, Traducción y glosas de la Eneida). "all fears set aside, he dared to oppose legal impediments"

(7) no queda otro remedio sino que, dexando aparte los muertos, los bivos que quedan pongan (1482-1492, Garci Rodríguez de Montalvo, Amadís de Gaula). "there is no choice but, leaving the dead aside, for those still living to remedy"

(8) Por tanto, dexadas lágrimas aparte, dezidme quién sois (1516, F. Bernal, Floriseo). “So, leaving tears aside, tell me who you are"

These absolute clauses spread very quickly in the 16th century, as we can see in the table below, which shows the frequency of the absolute construction dejado/a/os/as aparte $+\mathrm{NC}$ or its equivalent from the 15th-19th century. We can observe how this construction becomes fixed in the 16th century and begins to become less frequent after the 17th century when ellipsis occurs (see Table 1).

Table 1. Absolute construction frequencies over the centuries.

\begin{tabular}{cccccc}
\hline 12th-14th c. & 15th c. & 16th c. & 17th c. & 18th c. & 19th c. \\
\hline & 18 & 146 & 64 & 2 & 3 \\
\hline
\end{tabular}

The establishment of this construction made the two constant elements-the verb and adverb-begin to act like a semantic unit, favoring the start of a new process of grammaticalization. Although an increase in frequency alone is no proof that there is a process of grammaticalization (Octavio de Toledo y Huerta 2014), other formal changes confirm this point: Agreement between the past participle and its subject is lost (masculine dejado vs. feminine la cámara), the verbal form is exclusively masculine singular, and in many cases the adverb moves to the position immediately after the participle, as we can see in example (9): ${ }^{4}$

3 Both in Latin and Spanish the verbal ellipsis of ESSE or ser/estar occurs frequently, which in this case enables the adverb to situate the noun in space: "Un capítulo [que está] aparte" ("a chapter [that is] apart"). It could also be interpreted as a change in the construction of the locative complement: "Aparte del capítulo" > "en capítulo aparte" ("apart from the chapter" > "in a separate chapter" (see this example: Et ne huiusmodi donatio a me facta et obligatio a parte capituli repremissa possint in dubium revocari, 1269, Documentos notariales)). In any case, the possible ellipsis in these examples are not related to the process we will describe below, the verbal ellipsis of dejar o poner in absolute clauses.

4 Compare the constructions in examples (7) and (8): Dexadas lágrimas aparte vs. dejado aparte la cámara. 
(9) Y lo bueno que es que, dejado aparte la cámara a donde duermen y el estrado ... (1550, P. de Luján, Coloquios matrimoniales). "And the good thing is that, leaving aside the chamber where they sleep and the platform ..."

Semantic evolution of the overall meaning of the construction also takes place: 'Dejar a un lado' comes to be used in the sense of 'to ignore, to exempt' now; and 'poner a un lado' has the meaning of 'to add'. As an absolute clause, aparte usually has an exceptive meaning (10), though there is no shortage of examples with additive meaning (11):

(10) Éste será también mi gusto, porque, aparte nuestras peleas, don Benito es un amigo de corazón (1898, Á. Ganivet, Los trabajos del infatigable creador Pio Cid). "That will also be my pleasure, because, our quarrels aside, don Benito is a dear friend"

(11) y bien portado, casi daba gusto de socorrerle, aparte la obra de caridad (1898, Á. Ganivet, Los trabajos del infatigable creador Pío Cid). "and so well-behaved, that, quite apart from it being a charitable work, it was almost a pleasure to help him"

\subsection{Ellipsis and the Introduction of the Exceptive Particle}

The high frequency of the construction starts to erode the lexical meaning of the verbal element as it loses its specific semantic content and alternates—without an appreciable difference-with other verbal elements like poner or sacar:

(12) Romper con grandísima destreza, poniendo géneros aparte, (1599, M. Alemán, Primera parte de Guzmán de Alfarache). "breaking with extreme dexterity, putting goods aside,"

Over time, such unitary meaning would have made unnecessary the monotonous repetition of the less accurate meaning element (in this case, the verbal one: Dejar, poner, etc.) and would have favored ellipsis. The overall meaning of the expression would then fall on the element that remained, the adverb aparte, which initially expressed a circumstance of the verbal action and was reanalyzed as an exceptive modal adverb, meaning 'omitted', 'not being considered' as in (13).

(13) Pues sepan -replicó Sancho-, burlas aparte, que no solamente me toca a mí uno de los nombres que cada uno de vuessas mercedes tiene [ . . ] , sino [ . . ] (1614, A. Fernández de Avellaneda, Don Quijote de la Mancha). "“May you know” replied Sancho, "that, jokes apart, it's not just one of the names which each of Your Worships has that belong to me [ . . ], [but] ...'

\subsection{From Exceptive Particle to Adlative Additive Connector}

The origin of aparte as an additive connector is closely associated with these uses since in many of the cases in which it has an exceptive meaning, aparte is linked to what is properly argumentative: Reasons, fears, opinions, etc. are ignored or left aside. This contextual meaning favors the semantic-pragmatic change that leads aparte to become an element of additive connection within the argumentative discourse. The existence of ambiguous contexts confirms this, as we can see in (14), where aparte can mean either 'outside (in addition to)' or 'apart from':

(14) Para que los cobren y empleen en lo que aparte de este testamento dejare ordenado (1681, P. Calderón de la Barca, Testamento). "so that they collect and use them in what I shall order in addition to/apart from this will ..."

The close connection between the verbal ellipsis and the introduction of the connector is also evident in some examples where the elimination of the verbal element ([dejado]) results in the use of aparte as an additive marker, as in examples (15) and (16):

(15) Sol.-En llegando a Valladolid, me habéis de dar un traslado desta loa, porque, [dejado] aparte que es de mucho gusto, me quiero aprovechar de algún remedio para limpiarme los dientes, aunque los tengo tan malos que me parece imposible que yo venga a tener en mi vida buena 
dentadura (1603, A. de Rojas Villadrando, El viaje entretenido). "Sol.-When we arrive in Valladolid, you must give me a version of this prologue, because, quite apart from the fact that it is very pleasing, I want to use some remedy to clean my teeth, although they are in such a bad state that I think it is impossible that I will ever have a good set of teeth in my life"

(16) Ellos nacieron con libertad de hombres, y ellas con recato de mujeres. Y así, por lo que deben ser más culpadas, [dexando] aparte que son más desgraciadas, es que como son las que pierden más, luce en ellas más el delito. Y por esto, como los hombres se juzgan los más ofendidos, quéxanse y condénanlas en todo, y así están hoy más abatidas que nunca, porque deben de ser los excesos mayores. Demás de esto, (1647-1649, María de Zayas y Sotomayor, Desengaños amorosos). "Men are born with the freedom which is characteristic of men, and women are born with the modesty which is characteristic of women. And so it is that women must get blamed more, setting aside the fact that they are more unfortunate, because since they have more to lose, their misdeeds are more apparent. And on that account, since men judge themselves to be more greatly offended, they complain and condemn women in everything, and so women are now more oppressed than ever, because their excesses must be greater. Besides this ..."

We can observe the new functions developed by aparte after the 16th century in the following examples: Exceptive 'except for' (17) and additive 'in addition to' (18).

(17) ¿Y lo demás? Nada. Allí no hay sexo. Aparte del orden, parece el cuarto de un estudiante (1885-85, Clarín, La Regenta). "And the rest? Nothing. There is no sex. Except for its tidiness, it looks like a student's room"

(18) Carmen se confesaba en aquel instante a sí misma que toda la noche había pensado en el subteniente, que le era muy simpático, aparte de ser buen mozo; (1886, Clarín, Pipá). "At that moment, Carmen was admitting to herself that she had been thinking of the lieutenant all night long, and that she found him very agreeable as well as handsome;"

In modern Spanish, obviously, we are no longer dealing with cases of ellipsis: In (17) and (18), aparte is already used as a connector. We postulate that the verbal elision in absolute constructions with dejar and poner led to aparte being endowed with new meanings, exceptive and additive, as a connector, without the need to resort to more complex construction.

\section{The Specific Meaning of Aparte within the Additive Connection}

The pragmatic meaning of aparte as an additive connector shows the persistence of its etymological meaning, which is why we have called such an additive connector 'adlative' (Azofra Sierra 2014). It thus differs from cases where the addition is 'cumulative' or 'summative', for which connectors such as encima or además are used (Espinosa Elorza 2010, pp. 157-58).

As we can see in example (18), it is clear that aparte is a particle that has a very peculiar procedural additive meaning. It coincides with además - a prototypical connector of the set of additives-in that the argument it shows has the same orientation as the previous one: It is co-orientated. On the other hand, it differs from además in that the argument headed by the connector aparte is unnecessary to reach the conclusion - by contrast with the one introduced by además, which is deemed necessary. In this respect, aparte behaves like encima, a connector that also introduces an unnecessary argument. However, since the argument introduced by the connector is presented as following a different line from the preceding argument, the fact that it can have less argumentative force does not contradict the expectations of the speaker-something that can happen with the connector encima-and this is precisely the origin of its use as a counter-argumentative connector (Garachana Camarero 2008). Aparte 
also differs from encima in that its argument does not carry an excessive, cumulative load, nor does it carry a subjective nuance. ${ }^{5}$

As we can see in example (19), this is the peculiarity of aparte in its procedural meaning as additive connector (vs. other additives):

(19) Tal vez por ahí puedas tú encontrar la solución -le sugirió Julio García a Antonio Casal-. Dirigiendo uno de esos organismos. Aparte de que el tipo de labor, humanitaria, es de las que a ti te gustan, resolverías tu vida. (1961, J. María Gironella, Un millón de muertos). "Perhaps you can find the solution there: Managing one of those agencies," suggested Julio García to Antonio Casal. "Apart from the fact that this is the kind of humanitarian work you like, it would sort your life out."

Conclusion: to manage one of those agencies is the solution [to your problems]:

Argument 1: You would sort your life out;

Argument 2: You would do the type of job you like.

These are co-orientated arguments along different lines; the second is not necessary and it does not have greater argumentative force, nor does it have an excessive or evaluative nature (as opposed to encima). Being arguments of different types, they do not "add" anything to the reaching of a conclusion: They will not contradict the listener's expectations. We observe that it may even happen, as in this example, that the argument introduced by aparte acts as a reinforcement of the main argument, despite actually being a much weaker argument. At any rate, it is evident that the argumentation follows two separate paths since two different types of reason are presented.

In the evolution of aparte there is a semantic-pragmatic change which conventionalizes its meaning of omission, or voluntary relegation outside the central point of attention, which developed from the original locative meaning of the adverb, and this process is the basis of its use as an additive connector. Exception and addition can be seen as contextual readings of the same evaluative attitude from the speaker, who introduces something that is not essential (and may not even be important) to the argumentative sequence and must be considered as lateral or secondary to the particle aparte. The context will clarify to the listener whether he needs to add this as additional information ('poniéndolo al lado [del resto de la argumentación]') or dispense with it ('dejándolo a un lado').

However, the use of aparte as an exceptive particle is not entirely comparable to that of the most prototypical exceptive particles in Spanish (excepto and salvo): Unlike these, aparte is usually not interpreted as relating to a universal quantified expression: "Vinieron todos \{excepto/salvo/*aparte de\} ella" ["They all came except for her"]. This behavior may explain why aparte has developed an additive value that is not possible with the more univocal exceptive particles.

In other cases of grammaticalization, ellipsis also occurs in one of the elements of the original expression (cf. Garachana Camarero 1998, regarding the marker no obstante; Elvira 2009, regarding some expressions with concessive function; and Pérez Saldanya and Salvador 2014, regarding concessive constructions such as no obstante (esto), sin embargo (de que ... )). In our case, similarly, the contextual meaning of the expression has become conventionalized; in addition, ellipsis occurs because one of the elements, now semantically eroded, becomes dispensable.

\section{Aparte in Lexicographical Works}

Since the categorization of this particle is problematic, we consider it also necessary to carry out a specific study of the lexicographical treatment it has received, as in many cases this is very illustrative

5 Even though this is a matter that would require more specific attention, we cannot overlook the fact that the arguments linked by aparte may be inverted without affecting the meaning; something that does not happen with encima: (18) Dirigiendo uno de esos organismos, harías un trabajo que te gusta y aparte resolverías tu vida. 
of the changes undergone by the adverb and its resistance to an analysis which covers the whole complexity of its evolution. We provide some examples of interest in the final Appendix A: Diccionario de autoridades, Diccionario histórico de la lengua española, Diccionario de uso del español, Diccionario del español actual, Diccionario de la lengua española, Diccionario panhispánico de dudas.

Successive editions of the Real Academia Española (RAE)'s Diccionario de la lengua española - henceforth DRAE—have collected these changing meanings and have thus shown the difficulty in assigning a grammatical category to some of these new functions. We can observe how in DRAE 1803 the phrase dexar aparte ('to omit') is no longer present. Aparte maintains its categorization as an adverb of manner ('apart from, drawing a distinction') in its first meaning entry. In 1899, the adverb of manner is divided into two meanings: 'separadamente, con omisión' ('apart from, drawing a distinction') and 'con omisión, con preterición' ('omitting'). For the first time, we find the meaning as an adverb of place, in its purely locative meaning: 'en otro lugar' ('elsewhere'). In DRAE 1914, the adverbial uses of place split into two meanings: 'en otro lugar' ('elsewhere') and 'a distancia, desde lejos' ('at a distance, away'); there are no changes in its uses as adverb of manner. In 1970, the adjectival meaning is added, 'diferente, distinto, singular' ('different, peculiar)', with an example which is maintained until 2001: "Góngora es un autor APARTE en la poesía española". In RAE 1992, a new category is introduced:

Aparte de. loc. prepos. Con omisión de, con preterición de. U. t. sin la preposición y pospuesto al nombre. APARTE impuestos, impuestos APARTE. (RAE 1992)

In DRAE 2001, with the meaning 'con omisión de, con preterición de', it is considered a preposition, but in 2014 it is categorized as an adverb, even though the same examples and definitions are applied. Regarding additive meaning, only some lexicographical works explicitly mention an "additive" nature (Moliner 1970; Santos 2003). In the works by the RAE, we must understand that aparte is considered as a contextual variant of the adverb of manner: DHLE: "adv. m. Además de, separadamente"; DRAE: "adv. m. Separadamente, con distinción". (Cuervo [1886-1893] 1994) does not list aparte as an additive adverb, nor does he relate it to además or encima; he does not explicitly refer to the exceptive uses either (in no case does he employ paraphrases like 'fuera de' in order to explain the meaning of aparte). Problems of categorization have been reflected in the definitions found in lexicographical works. The categorization of some uses is quite heterogeneous. We find these conflicting uses:

- $\quad$ Aparte de esto: Prepositional vs. adverbial phrase. Aparte has the potentiality for prepositional (aparte de) and conjunctive (aparte [de] que) extension.

- $\quad$ Phrases like un cuaderno aparte, 'independent': Postnominal preposition vs. adjective vs. adverb as noun complement.

- $\quad$ Absolute clauses of the bromas aparte type or independent complements like impuestos aparte: Postnominal preposition vs. adjective vs. adverb following the ellipsis of a verb such as dejar.

- $\quad$ Aparte as attribute? El café es aparte: Adjective vs. locative adverb.

As explained in Azofra Sierra (2011), problems in categorization are largely due to the elision that has taken place in the evolutionary process.

\section{Conclusions}

We have reviewed the process of evolution of the connector aparte, attempting to find in its history the reasons for its specific meaning as an additive connector, which distinguishes it from other additives: when it adds an argument, the marker indicates that this is not necessary to reach the conclusion, but neither is it an element of greater argumentative force than the first one, and in fact, what the hearer must infer is that the argument introduced by aparte permits the reaching of the same conclusion as that expressed by the first argument, but via by another track of reasoning. Aparte is also an additive connector, but it presents specific characteristics linked to its etymological meaning; thus, compared to other connectors that show addition in their vertical dimension (like encima or sobre esto), aparte does so in a horizontal dimension, like junto/juntamente con esto, medieval allende de esto 
or fuera de esto: That is to say, one item is added next to another. Hence, the additives of this type can express addition and exception simultaneously. This special type of connection, which we call 'adlative addition', is to be considered the characteristic property of aparte (and fuera de, or medieval allende de): These connectors are used to introduce arguments that follow another route or pathway in reasoning, adding elements of a different type. Besides the additive function, some of the works consulted explicitly distinguish two meanings of aparte: Additive and exceptive. These meanings are very close, and can even occasionally coincide, precisely because of the special meaning of aparte as an additive to which we have referred above.

At the theoretical level, the study of the evolution of aparte allows us to draw some conclusions about the explanatory capacity of different mechanisms proposed to explain linguistic changes: Constructionalization, grammaticalization, or the relationship of this with adfunctionalization and refunctionalization processes. We have seen that grammaticalization cannot explain all the processes of change and that grammaticalization and lexicalization are not opposing processes: In the elision of aparte, there are changes which are characteristic of grammaticalization, but the elision of the verb causes the entry of a new item in the lexicon: Aparte 'with omission'. It would be questionable whether all processes of grammaticalization give rise to grammatical elements or whether some of these processes result in lexical items of great complexity due to the lexical load which they have inherited from the original constructions.

On the other hand, attention should be called to the enormous complexity that changes by elision can cause in the categorical values of the new forms, as is evident in the case of aparte: The problems of categorization of the new polyfunctional form, which are reflected in the lexicographical works, show the great grammatical complexity of the units which are the result of changes by elision, due in large measure to the inheritance of the meanings of the entire initial construction.

Finally, we have highlighted the importance of context in the changes due to elision by which aparte becomes an exceptive/additive particle. Our study has attempted to make it clear that elision must be taken into account as a mechanism in explaining the linguistic change since it often initiates processes which are complementary to those of grammaticalization and can contribute to a better understanding of some of the complex processes of change such as those undergone by the particle aparte.

Funding: This research received no external funding.

Conflicts of Interest: The author declares no conflict of interest.

\section{Appendix A. The Particle Aparte in Lexicography ${ }^{6}$}

\section{Diccionario de Autoridades (RAE 1726)}

APARTE. adv. Separadamente, con distinción y separación: y assi se dice Pon esto aparte, guárdalo aparte. Lat. Separatim, Seorsim. // APARTE. En las Comedias es lo que el cómico dice y representa sin que lo entienda y oiga la Persona, ò Personas con quienes habla, [ ... ] Lat. Clam. Seorsim. [ . . . ] / / Dexar una cosa aparte. Se dice en la conversación, quando se entromete alguna espécie que la interrumpe, ò que no es del intento para lo que se trata. [ ... ]. Lat. Praetermittere, omittere. [ ... ]

Diccionario histórico de la lengua española (DHLE) (Academia Española 1933)

APARTE. (Del lat. ad, a, y pars partis, parte.) adv. 1. Hacia parte o sitio retirado. 2. En parte retirada, en otro lado. 3. Del lado de. 4. adv. m. Además de, separadamente. [ ... ] 5. Se usa a modo de preposición pospuesto al nombre. $[\ldots]^{7}$

6 The entries listed are not complete: non-problematic cases have not been included (for example, meanings as noun).

7 We have omitted the remaining meanings, which relate to its use as a noun. 


\section{Diccionario de uso del español (DUE) (Moliner 1970)}

aparte. (De "parte"). 1. ("Dejar, estar, tener"). Adverbio con que se expresa la situación de una cosa separada de otras que se consideran, con las cuales estaba antes o con las cuales tiene alguna relación. [ ... ] ‘Por separado. Separadamente'. [ . . . ] Se emplea como adjetivo en expresiones como "un grupo aparte, rancho aparte". (fig; "Dejar. Tener"). Con preterición o desprecio; no dando a la persona de que se trata participación en las ventajas o en la sociedad de otros. [ ... ]

APARTE DE. (I) Prescindiendo de la cosa que se expresa. [ . . . ] (II) Además de. [ . . . ]

APARTE DE QUE. Expresión conjuntiva de las que pueden llamarse "aditivas", equivalente a "además de que $^{\prime \prime} .[\ldots]$

DEJAR APARTE. Dejar sin tratar por el momento cierta cosa. [ . . . ]

ESO APARTE. Forma absoluta muy frecuente, usada por "aparte de eso".

\section{Diccionario del español actual (DEA) (Seco et al. 1999)}

aparte I adv 1 En lugar o situación separados con respecto a alguien o algo mencionado o presente, o con respecto a las perss. o cosas corrientes. (b) Continuando en el renglón siguiente. (c) En lugar o situación que permite la privacidad o la discreción. (d) [ ... ]. 2 Sin ser considerado o mencionado. Con vs como DEJAR, PONER, QUITAR, ECHAR $o$ QUEDAR. (b) Frec se omite el v, quedando el adv pospuesto o antepuesto al sust. (minucias aparte, aparte bromas ahora). II adj invar 3 Diferente o distinto [de alguien o algo mencionado, o de las perss. o cosas corrientes] (ser aparte, comer en escudilla aparte). (b) Independiente (suelen ser tiradas aparte). III prep 4 Además de. Tb, más frec, . DE. 5 Fuera de o con excepción de. Tb, más frec, $\sim$ DE.

\section{Diccionario de la lengua española (RAE and ASALE 2014)}

aparte. (De $a^{1}{ }^{1}$ y el lat. pars, partis, parte).1. adj. Diferente, distinto, singular. Góngora es un caso aparte en la poesía española. 2. $\mathrm{m}$. En el teatro, palabras que dice un personaje fingiendo hablar consigo mismoo dirigiéndose a otro $u$ otros, y dando por supuesto que no las oyen los demás. 3 . m. Conversación privada que mantienen dos o más personas, al margen deotras que se hallan en el mismo lugar. 4. m. Ejemplar de una tirada aparte. 5. m. Ar. Espacio o hueco que, tanto en lo impreso como en lo escrito, se deja entre dos palabras. 6. m. Arg., Col. y Ur. En un rodeo, separación que se hace de cierto número de cabezas de ganado. 7. adv. En otro lugar. Poner un libro aparte. 8. adv. A distancia, desde lejos. 9. adv. Separadamente, con distinción. 10. adv. Con omisión de, con preterición de. Aparte impuestos. Impuestos aparte. 11. adv. En el teatro y referido al modo de decir su texto un personaje, fingiendo hablar consigo mismo o dirigiéndose a otro u otros, dando por supuesto que no lo oyen los demás. U. normalmente como acotación. aparte de. loc. prepos. fuera de (\| además de). Aparte de impuestos, el precio se mantuvo.

aparte. Puede funcionar como adverbio, como adjetivo, como sustantivo y como preposición:

(a) Como adverbio significa 'en otro lugar'. [ ... ]. Con verbos como dejar, poner y similares, aparte significa también 'fuera o al margen': «Dejando aparte la moral, quizá su negativa daba de él una imagen equivocada» (SchzEspeso Alas). En estos casos, es frecuente la omisión del verbo, pudiendo quedar el adverbio antepuesto o pospuesto al sustantivo: «La doctrina europeísta ha tenido, aparte su acierto o su error, una utilidad indiscutible» (CSerraller Paisajes); "Pero bromas aparte, yo empiezo a sentir miedo» (Tusquets Mar). Como todos los adverbios, es invariable [... ]. (b) Como adjetivo significa 'distinto o singular': "Cada cosa de este mundo [...] era un caso aparte, una singularidad que no admitía comparaciones» (Pombo Metro). Es invariable en plural: «[ ... ] integrar, en publicaciones aparte, los datos [ ... ]. (c) Como sustantivo es masculino y se usa normalmente con los sentidos de 'palabras que, en un texto teatral, dicen uno o más personajes fingiendo que no las oyen los demás presentes en la escena' y 'conversación entre dos o más personas al margen de otras presentes' [ . . . ]. (d) Forma la locución preposicional aparte de, que significa 'con omisión de, al margen de' [ . . . . En la lengua culta debe evitarse el uso de la locución popular fuera aparte (de) [ . . . ]. Está muy extendido, y es válido, el empleo de aparte de con el sentido de 'además de' [ ... ].

\section{References}

Academia Española. 1933. Diccionario histórico de la lengua española. Madrid: Editorial Hernando. Azofra Sierra, María Elena. 2011. Historia de la partícula aparte en español. Revue Romane 46: 42-68. [CrossRef] 
Azofra Sierra, María Elena. 2014. Conexión y conectores aditivos en español: Estudio diacrónico. In Marqueurs $d u$ discours dans les langues romanes: Une approche contrastive. Edited by Margarita Borreguero and Sonia Gómez-Jordana. Limoges: Lambert Lucas, pp. 175-95.

Company, Concepción Company. 2004. Gramaticalización por subjetivización como prescindibilidad de la sintaxis. Nueva Revista de Filología Hispánica 52: 1-28. [CrossRef]

Cuervo, Rufino J. 1994. Diccionario de construcción y régimen de la lengua castellana. Edited by Instituto Caro y Cuervo. Santafé de Bogotá: Instituto Caro y Cuervo, vol. 8. First published 1886-1893.

Elvira, Javier. 2009. Mal que le pese, pese a que y otros 'pesares'. Gramaticalización y lexicalización en la lengua medieval. In Fronteras de un diccionario: Las palabras en movimiento. Edited by Elena de Miguel, Santiago U. Sánchez, Ana Serradilla, Romana-Anca Radulescu and Olga Batiukova. San Millán de la Cogolla: Cilengua, pp. 273-94.

Espinosa Elorza, Rosa María. 2010. Procesos de formación y cambio en las llamadas "palabras gramaticales". San Millán de la Cogolla: Cilengua.

Garachana Camarero, Mar. 1998. La evolución de los conectores contraargumentativos: La gramaticalización de no obstante y sin embargo. In Los marcadores del discurso. Teoría y análisis. Edited by M. Antonia Martín Zorraquino and Estrella Montolío. Madrid: Arco Libros, pp. 193-212.

Garachana Camarero, Mar. 2008. En los límites de la gramaticalización. La evolución de encima (de que) como marcador del discurso. Revista de Filología Española 88: 7-36. [CrossRef]

Garachana Camarero, Mar. 2015. Teoría de la gramaticalización. Estado de la cuestión. In Actas del IX Congreso Internacional de Historia de la Lengua Española. Edited by José M. García Martín. Madrid and Frankfurt am Main: Iberoamericana \& Vervuert, vol. 1, pp. 331-60.

Hopper, Paul J., and Elisabeth Closs Traugott. 2003. Grammaticalization. Cambridge: Cambridge University Press. First published 1993.

Moliner, María. 1970. Diccionario de uso del español (DUE). Madrid: Gredos.

Octavio de Toledo y Huerta, Álvaro S. 2014. Espejismo de la frecuencia creciente: gramaticalización y difusión del artículo ante oraciones sustantivas. Rilce 30: 916-58.

Pérez Saldanya, Manuel, and Vicent Salvador. 2014. Las oraciones concesivas. In Sintaxis histórica de la lengua española. Tercera parte: Preposiciones, adverbios y conjunciones. Relaciones internacionales. Edited by Concepción Company. México: Fondo de Cultura Económica \& Universidad Nacional Autónoma de México, pp. 3697-839.

Pons Rodríguez, Lola. 2010. Los marcadores del discurso en la historia del español. In Los estudios sobre marcadores del discurso en español, hoy. Edited by Óscar Loureda and Esperanza Acín. Madrid: Arco Libros, pp. 523-615.

Real Academia Española (RAE). 1992. Diccionario de la lengua española (DRAE). Madrid: Espasa.

Real Academia Española (RAE), and Asociación de Academias de la Lengua Española (ASALE). 2005. Diccionario panhispánico de dudas. Madrid: Espasa.

Real Academia Española (RAE), and Asociación de Academias de la Lengua Española (ASALE). 2009. Nueva gramática de la lengua española (NGLE). Madrid: Espasa.

Real Academia Española (RAE), and Asociación de Academias de la Lengua Española (ASALE). 2014. Diccionario de la lengua española. Madrid: Espasa.

Santos, Luis. 2003. Diccionario de partículas. Salamanca: Luso-Española de Ediciones.

Seco, Manuel, Olimpia Andrés, and Gabino Ramos. 1999. Diccionario del español actual (DEA). Madrid: Aguilar. Smith, John C. 2011. Change and Continuity in Form-Function Relationships. In The Cambridge History of the Romance Languages. Edited by Martin Maiden, John Charles Smith and Adam Ledgeway. Cambridge: Cambridge University Press, vol. 1, pp. 268-317.

Traugott, Elizabeth Closs, and Graeme Trousdale. 2013. Constructionalization and Constructional Changes. Oxford: Oxford University Press.

(C) 2019 by the author. Licensee MDPI, Basel, Switzerland. This article is an open access article distributed under the terms and conditions of the Creative Commons Attribution (CC BY) license (http:/ / creativecommons.org/licenses/by/4.0/). 
Article

\title{
On the History of Ante(s): Exaptation of Adverbial -s?
}

\author{
Dorien Nieuwenhuijsen \\ Faculty of Humanities, Department of Languages, Literature and Communication, \\ Utrecht Institute of Linguistics OTS, Utrecht University, 3512 JK Utrecht, The Netherlands; \\ D.Nieuwenhuijsen@uu.nl; Tel.: +31-30-2536363
}

Received: 6 October 2018; Accepted: 19 November 2018; Published: 23 November 2018

\begin{abstract}
In this paper we will describe the historical development of the Spanish doublet ante-antes ('before') and explore the question whether a process of exaptation is involved (cf. Lass 1990). We will argue that the final $-s$ of antes, that originally marked the adverbial status of the word, in the course of time had become a kind of morphological 'junk' (cf. Lass 1990) and, subsequently, could be exploited in order to encode the semantic opposition between temporal meaning on the one hand, and adversative meaning on the other hand. However, based on quantitative data we will show that the incipient semantic redistribution over the course of the 16th century rather suddenly collapsed, leading to a differentiation between the prepositional ante and adverbial antes.
\end{abstract}

Keywords: adversativity; ante-antes; exaptation; temporality; preferentiality

\section{Introduction}

Currently, the only productive means to form an adverb in Spanish is by way of the suffix -mente, which is added to the female form of the adjective (lento > lentamente, 'slow' > 'slowly'). This suffix originally was a Latin noun, mens ('mind'), used in the ablative case to indicate the state of mind of someone, and subsequently the way in which an action was performed (Penny 2004, p. 131). However, in Old Spanish the adverbial function could also be explicitly marked by a final $-s$. Since a number of Spanish adverbs of Latin origin already ended in -s (e.g., magis > más, 'more'; laxius > lejos, 'distant'; foras $>$ fueras, 'outside', 'except'), by means of analogy in Old Spanish the $-s$ was added to other adverbs that originally lacked this final consonant (e.g., in tunc > entonces, 'so'; dum interim > domientre > demientre > mientras, 'while'; numquam > nunqua > nunquas, 'never') (Azofra Sierra 2014, p. 377; Corominas and Pascual 1984, p. 277; Menéndez Pidal 1976, p. 296; Penny 2004, p. 131). ${ }^{1}$ Eventually, while some adverbs maintained their analogous $-s$ (e.g., entonces, mientras), other longer forms disappeared, particularly during the Middle Ages (e.g., fueras, nunquas). Still others kept both forms creating doublets, e.g., the adverbs quizá and quizás ('perhaps'), which both express uncertainty or possibility and, according to the Diccionario Panhispánico de Dudas (Real Academia Española 2005, s.v. quizá) are both valid forms.

Another doublet in Modern Spanish is ante-antes ('before') but this pair differs from quizá-quizás, because nowadays the two forms show clear-cut distinctions as far as their functions and meanings are concerned, although in Old Spanish ante y antes had similar functions and meanings.

It is this doublet that we will discuss in detail in the present paper. In Section 2 we will start sketching the historical development of the two adverbs ante and antes. Subsequently, in Sections 3

1 Ortiz Ciscomani (2014) studies adverbial phrases with the preposition $a$ ('to') and a lexical element ending in -as (e.g., $a$ cuestas, 'on one's back'). She states that the -as ending is usually associated with Latin accusative feminine plural, although in many instances of the adverbial phrase scheme there seems to be no logical reason for the use of a feminine plural ending (cf. a ciegas, 'blindly', which is rooted in the adjective ciego, 'blind'). In our view these adverbial phrases differ from simple adverbs like más or lejos, since the final $-s$ in the latter clearly is not a plural marker. 
and 4 we will present quantitative data taken from a corpus especially compiled for the present paper, that will allow us to outline the main distributional similarities and differences between the two forms. Finally, Section 5 summarizes the main findings of our research and discusses their theoretical implications. Particularly, we will focus on the question whether the observed language change can be regarded as a case of exaptation.

\section{The Case of the Spanish Doublet ante-antes}

The Spanish forms ante and antes both derive from Latin ante ('before'), which functioned either as an adverb or preposition. In Old Spanish ante and antes conveyed all the meanings ante already had in Latin, i.e., temporal and spatial meanings, although the longer form antes never appears to have expressed spatial meaning in Spanish (Alvar and Pottier 1993, p. 311; Azofra Sierra 2014, p. 379). ${ }^{2}$ Moreover, derived from the original meaning, ante and antes acquired a more abstract meaning of precedence, to express the idea of preference in comparisons or contrast in adversative relations (cf. Azofra Sierra 2014, pp. 392-96; Cuervo 1886/1994, p. 485; Elvira 2009; Espinosa Elorza 2010, pp. 104-7; Garachana Camarero 1998; Herrero Ruiz de Loizaga 2005, pp. 71-72; Iglesias Recuero 2014, pp. 2560-61 and 2600 ff.; Keniston 1937, p. 630; Menéndez Pidal 1976, p. 393 and 468; Nieuwenhuijsen 2012). These preferential and adversative meanings seem to be a Late Latin or Romance innovation, given that they are not listed in Latin (Azofra Sierra 2014, p. 392; Iglesias Recuero 2014, p. 2560). ${ }^{3}$ In Section 4 we will discuss the different meanings in more detail on the basis of several illustrative examples.

On the other hand, in Modern Spanish ante only functions as a preposition, to locate the position of someone or something in relation to someone or something else (ante el tribunal, 'before the court') i.e., it only retains the spatial meaning that it already had in Latin. ${ }^{4}$ By contrast, antes in Modern Spanish only has an adverbial value, with temporal, preferential or adversative meaning. ${ }^{5}$

Thus, the different functions and meanings of the Latin ante seem to have been redistributed among its two descendent forms ante and antes.

According to Azofra Sierra (2014, pp. 379-80) and Octavio de Toledo y Huerta (Octavio de Toledo y Huerta 2014, p. 1899) the functional differentiation of ante and antes was accomplished in the (mid) 16th century, although Cuervo (Cuervo 1886/1994, p. 480) states that in those days ante sometimes still was used as an adverb, in accordance with the practice of former times.

As far as their meanings are concerned, it appears that in Old Spanish the two adverbs ante and antes were used indifferently to indicate temporal, preferential or adversative meaning. Studies about the evolution of adverbs sometimes treat the two forms as if they were synonymous and stood in free variation to each other, starting with Nebrija (Nebrija 1495/1951) who in his Spanish-Latin vocabulary simply gives "ante o antes adverbio. antea" (cf. also Alvar and Pottier 1993, p. 311; Espinosa Elorza 2010, pp. 104-7; Elvira 2009, p. 105; Iglesias Recuero 2014, pp. 2560 and 2600; Keniston 1937, p. 630; Menéndez Pidal 1982, p. 333).

However, in the case of ante, Octavio de Toledo y Huerta (Octavio de Toledo y Huerta 2014, p. 1899) points at an early tendency of morphosyntactic differentiation of the spatial and temporal meanings, whereby antes came to express temporality, leaving the prepositional ante with the spatial meaning. While, as stated before, this holds true from the mid 16th century onwards, it does not

2 In spite of this, in his dictionary of the Castilian language, originally published in 1886, Cuervo (Cuervo 1886/1994, p. 486) does list the spatial meaning of antes, and although in most of the cited examples antes is combined with de or que, thus becoming a preposition or conjunctive, he also presents some examples of the bare antes, especially used in written texts to refer to something discussed earlier.

3 However, the Oxford Latin Dictionary (Glare 1968-1982, p. 138) includes for the prepositional ante (yet not for the adverbial ante) as its last meaning: "before (in choice, preference, etc.), above, more than".

4 For the development of the preposition ante cf. Octavio de Toledo y Huerta (Octavio de Toledo y Huerta $2014, \mathrm{p} .1897 \mathrm{ff}$ ).

5 Antes can behave as a preposition, in Old Spanish as well as Modern Spanish, but only when it is followed by the preposition de (antes del fin de semana, 'before the weekend'). 
explain nor take into account the semantic distribution of ante and antes in their adverbial function in earlier times. Moreover, based on an analysis of a large corpus of examples, Azofra Sierra (2014, pp. 379-80) arrives at some interesting conclusions about the distribution of the two forms and their meanings. She argues that in the 12th and 13th century ante was mainly spatial, whereas antes was temporal. The 14th and 15th century witnessed a predominance of ante with temporal meaning, alongside antes that primarily expressed preferential/adversative meaning. On the other hand, from the 16th century onwards ante was exclusively used for spatial reference, while antes completely seized the temporal meaning, in addition to the preferential/adversative meaning. However, it should be noted that the percentages given by Azofra Sierra (2014, p. 380) reflect the distribution of the three different meanings (locative, temporal and preferential/adversative) within each form separately and, therefore, do not necessarily inform about the preferred form per meaning. For that reason, a closer look at which of the two forms predominated in the 14th and 15th century if preferential/adversative meaning was to be expressed, reveals that in the 15th century it is ante (19 occurrences) which is found more in contexts of preferential/adversative meaning than antes (12 occurrences). The evolution of ante and antes, then, seems to have been less straightforward as Azofra concludes.

In spite of this qualification, the data provided by Azofra seem to suggest that, apart for the functional differentiation between preposition or adverb, an interesting kind of semantic differentiation also took place, in which the adverbial doublet ante-antes was exploited to express different semantic values. At some point in the history of the Spanish language, antes appeared to have been incorporating the preferential and adversative meanings, whereas ante was reserved for temporal meaning. However, this process of redistribution was interrupted quite suddenly in the 16th century, when adverbial ante fell into disuse.

\section{The Data-Distribution of the Forms ante and antes}

In order to check the above summarized claims and study more in detail the functional and semantic development of ante and antes, we collected a corpus of examples taken from the Gradia corpus, which contains 490 documents of different lengths, with different text genres and roughly covers the period from the 12 th century to the present. ${ }^{6}$ Since not all genres supply texts for the period in which the development of ante and antes appears to have taken place, we only selected those genres that incorporate texts dating from the 13th century to at least the 16th century. Despite the fact that Azofra Sierra (2014, p. 380) asserts that from the 16th century on ante loses its temporal, preferential, and adversative meanings and only survives with locative meaning as a preposition, for two genres we also included some 17th century texts, in order to assure we would not miss out some of the possibly interesting last cases of adverbial ante. Of every text, we included all cases of adverbial ante (1a and b) and antes ( $2 \mathrm{a}$ and $\mathrm{b})$, but eliminated instances of the prepositional ante (3a) and antes de (3b), as well as instances of the conjunctives ante que (4a) and antes que (4b). Thus, our corpus totals 1531 examples, 371 cases of adverbial ante and 1160 of adverbial antes.

(1) a. E despues que el rrey don sancho llego a xerez los dela villa que ante estauan çercados fueron muy conortados conla su venjda. (anonymous, Crónica de Sancho IV, C14) "And after that king don Sancho arrived at Jerez, the people of the city that before were besieged felt very comforted with his arrival".

b. $\quad \mathcal{E}$ no $<n>$ se acuyte de andar ante se tarde por algunos dias fasta $q<u e>$ l rrestauramj $<$ ent $><<0>>$ sea muy bie $<n>$ rreforçado $\mathcal{E}$ co $<n>$ firmado. (Tederico, Cirugía, C16) "and do not hurry to walk rather take some days until the restoration is well reinforced and confirmed".

6 The corpus was originally created by the research group Gradia for their work on verbal periphrases. It covers the following genres: legal, notarial, historiographical, technical, narrative, essayistic, epistolary, philosophical, political, dialogic, journalistic, oral and theatrical texts. The corpus contains over 20 million words. For more details, see http: //gradiadiacronia.wixsite.com/gradia/corpus-gradia. 
(2) a. enlo qual se cumplio lo que Esopo vn poco antes dixera asu amo. (anonymous, Esope historiado, C15) "in which was achieved what Aesop a bit before had said to his master".

b. Mas los xpistianos de tierra de Suria non auien mengua antes auien uiandas assaz. (anonymous, Gran conquista de Ultramar, C13) "But the Christians of the land of Syria did not have lack rather they had a lot of food".

(3) a. $\mathcal{E}$ dixo non fables ante ningun omne fasta que oyas sus palabras. (anonymous, Poridat de poridades, C13) "and he said do not speak before no man until you hear his words".

b. $\quad$ y aunque hacía mal tiempo llegó al puerto Mano á las once horas antes de medio día, (Alonso de Santa Cruz, Crónica del Emperador Carlos V, C16) "and although it was bad weather he arrived at the harbour Mano at eleven o'clock before noon".

(4) a. E ante que muriese mando en su testamento con grand amor que auia a aquella cibdad que ouiera ganado de moros (Diego Rodríguez de Almela, Valerio de las historias eclesiásticas y de España, C15) "And before he died he ordered in his will with great love that he had for that city which he had won from the Moors"

b. y no se han de comer hasta el mes de Agosto, y antes que llueua. (Tomás de Murillo y Velarde, Tratado de raras y peregrinas yervas, que se han hallado en esta Corte, C17) "and they [a certain plant] should not be eaten until the month of August, and before it rains".

In Table 1 we present quantitative data of ante and antes ordered by century.

Table 1. Frequencies of ante and antes per century.

\begin{tabular}{cccc}
\hline Century & ante & antes & Total \\
\hline 13 & $23.1 \%(123)$ & $76.9 \%(409)$ & $100 \%(532)$ \\
14 & $29.9 \%(95)$ & $70.1 \%(223)$ & $100 \%(318)$ \\
15 & $40.6 \%(93)$ & $59.4 \%(136)$ & $100 \%(229)$ \\
16 & $19.5 \%(60)$ & $80.5 \%(248)$ & $100 \%(308)$ \\
17 & $0 \%(0)$ & $100 \%(144)$ & $100 \%(144)$ \\
\hline total & $24.2 \%(371)$ & $75.8 \%(1160)$ & $100 \%(1531)$ \\
\hline \multicolumn{4}{c}{ Chi-square $(4, N=1531)=89.174, p=0.000 * * * 7}$.
\end{tabular}

The data of Table 1 show that from the 13th century onwards the corpus contains both adverbs, until the 17th century, when the texts only render cases of adverbial antes, definitely restricting ante to prepositional use, as was already claimed by Azofra Sierra (2014, p. 380). Interestingly, Table 1 also reveals that in the course of time there is fluctuation and co-existence of the two forms (cf. Aitchison 2013, pp. 100-1 and 126), although the non-etymological antes as an adverb has always been more frequent than its counterpart ante.

As mentioned before, in compiling our corpus we selected different text genres, which allows us to check whether the observed evolution is similar for all genres or is more or less prominent according to certain discourse traditions. Table 2 displays the distribution of ante and antes per century in historiographical, philosophical and technical texts. ${ }^{8}$

A closer look at the three different text genres, historiographical texts, philosophical prose and technical texts, puts on display some interesting differences between them. ${ }^{9}$ Whereas in the first genre

7 The result is significant at $p=0.01$. This level of significance is maintained for all chi-square calculations in this chapter.

8 For philosophical and technical texts, we selected all the documents the Gradia corpus contains (717,513 and 833,716 word tokens respectively), for historiographical texts we selected only part of the total amount of texts in this genre. Even so, because we wanted to select several texts per century, the number of word tokens $(2,093,277)$ for this genre is higher than for the other two. It goes without saying that this difference in word tokens does not affect the comparability of the data of Table 2, since the percentages reflect relative frequency.

9 For the present research we selected three historiographical texts from the Gradia corpus. However, as far as the Anales de Aragón by the historian Jerónimo Zurita are concerned, we only took into account a small part of the work (approximately 
adverbial ante, compared to antes, has always been rather rare, in the other two genres the use of ante persists much longer. As Table 2 reveals, the philosophical prose and technical texts pattern together until the 16th century, when use of ante falls to $13 \%$ in philosophical prose, but maintains itself at $59.3 \%$ in technical texts. Interestingly, the decrease of the use of ante (against antes) from the 15th to the 16th century in philosophical prose is statistically significant $(p=0.000 * *)$, while the apparent retention of ante in technical texts in the 16th century lacks statistical significance. Even so, in the 17th century ante has fallen into disuse in both historiographical and technical texts. Moreover, it merits noting that in philosophical prose the frequency of antes increases steadily over time, while in technical texts the use seems to oscillate and even decrease between the 14th and 16th century.

Table 2. Frequencies of ante and antes per century and per text genre.

\begin{tabular}{ccccccc}
\hline & \multicolumn{2}{c}{ Historiographical } & \multicolumn{2}{c}{ Philosophical } & \multicolumn{2}{c}{ Technical } \\
\hline Century & ante & antes & ante & antes & ante & antes \\
\hline 13 & $4.3 \%(18)$ & $95.7 \%(396)$ & $88 \%(44)$ & $12 \%(6)$ & $89.7 \%(61)$ & $10.3 \%(7)$ \\
14 & $18.1 \%(38)$ & $81.9 \%(172)$ & $53.2 \%(50)$ & $46.8 \%(44)$ & $50 \%(7)$ & $50 \%(7)$ \\
15 & $24.7 \%(20)$ & $75.3 \%(61)$ & $45.9 \%(39)$ & $54.1 \%(46)$ & $54 \%(34)$ & $46 \%(29)$ \\
16 & $0 \%(0)$ & $100 \%(171)$ & $13 \%(6)$ & $87 \%(40)$ & $59.3 \%(54)$ & $40.7 \%(37)$ \\
17 & $0 \%(0)$ & $100 \%(118)$ & $-\dagger$ & - & $0 \%(0)$ & $100 \%(26)$ \\
\hline total & $7.6 \%(76)$ & $92.4 \%(918)$ & $50.5 \%(139)$ & $49.5 \%(136)$ & $59.5 \%(156)$ & $40.5 \%(106)$ \\
\hline
\end{tabular}

+ For philosophical prose, we do not have data for the 17th century, since the Gradia corpus does not contain texts of this genre for this particular period; historiographical chi-square $(4, N=994)=96.104, p=0.000^{* * *}$; philosophical chi-square $(4, N=275)=54.944, p=0.000^{* * *}$; technical chi-square $(4, N=262)=65.291, p=0.000^{* * *}$.

\section{The Data-Distribution of the Meanings of ante and antes}

As mentioned earlier, in Old Spanish the two adverbs could have temporal, preferential or adversative meanings. The examples grouped under (5) are instances of ante with its different meanings, the examples of (6) correspond to the three meanings of antes.

Whereas the temporal meaning is clearly different from the preferential as well as the adversative meaning, the last two are somehow similar, as they share the idea of precedence. In order to distinguish between preferential and adversative meanings we classified an example as 'preferential' when both the preferred object or action and the second term of the expressed preference were present in the immediate context and the two terms of the comparison referred to the same person or object, as is the case in example (5b) (deuen de morir vs. se dexar venir a seruidumbre, los que son libres) and in (6b) (spirituales vs. corporales, tus mercadurias).

temporal ante

(5) a. de guisa que los faz nacer por fuerça. E a los que son blancos. tinnelos de la color que eran ante. (Alfonso X, Lapidario, C13) "so that it makes them [the hairs] grow forcibly and those that are white it dyes them with the colour they were before".

preferential ante

b. los que son libres ante deuen de morir que se dexar venir a seruidumbre. (Diego Rodríguez de Almela, Valerio de las historias eclesiásticas y de España, C15) "those who are free rather should die than let themselves come to servitude."

adversative ante

215.000 tokens), in order to keep the total number of word tokens for 16th century historiographical prose in relative balance with the total number of word tokens in the 16th century of the other two text genres. It is worth mentioning that in the work of Zurita still five cases of adverbial ante are documented. 
c. E el Respondio le ante te digo que si tu quesieres comer destas verças non seras lisonjero mas diras palabras de verdat (Sancho IV, Castigos y documentos para bien vivir, C14) "And he answered him rather I tell you that if you (would want to) eat from these cabbages, you will not be flattering but will tell the truth"

temporal antes

(6) a. Quiero esso mismo / que sepas que enel tiempo dela peste / aquellos mueren antes / en cuyas casas hay fedores particulares (Taranta, De epidemia et peste. Tratado de la peste, C15) "I also want you to know that in time of the plague those die first in whose houses are particular stenches"

preferential antes

b. E dixo pugna que tus mercadurias sean antes spirituales que corporales (anonymous, Bocados de oro, C13) "And he said strive that your goods are rather spiritual than corporal"

adversative antes

c. Mas estas cosas no las creyó Alvarado, antes decía que los indios no decían la verdad (Pedro Cieza de León, Las guerras civiles del Perú, C16) "But these things Alvarado did not believe, rather he said that the Indians did not say the truth"

Diachronically, the preferential meaning seems to have been first in developing out of the temporal meaning, followed by the adversative meaning (cf. Azofra Sierra 2014, pp. 379 and 392; Herrero Ruiz de Loizaga 2005, p. 71; Iglesias Recuero 2014, p. 2560; Nieuwenhuijsen 2012), an evolution that is consistent with the idea that priority or preference can lead to adversativity (Garachana Camarero 1998, p. 601$){ }^{10}$

According to Garachana Camarero (1998, p. 601) adversative connectives like antes signal a notion of priority at the textual level, marking the preference of one argument over another. Elvira (2009, pp. 104-5) characterizes the connective antes as a piece that opposes two elements in a certain part of the discourse and denotes the conceptual or logical preference or priority of one of these elements. Both authors, thus, assume a strong connection between the concepts of priority or preferentiality and adversativity.

In our corpus we find examples that can either have a temporal or a preferential reading. The two meanings share a sense of precedence, which in the case of temporal meaning obviously is related to time, whereas in the case of preferential meaning a more abstract sense of precedence is involved, i.e., the speaker mentally places one event before the other, making an implicit comparison between them. Furthermore, the preferential and the adversative meaning both highlight the notion of precedence, the former making a comparison, the latter stating a contrast. Thus, our corpus also happens to contain examples that allow for either a preferential or an adversative meaning.

First consider (7a), in which, in spite of the fact that the syntactic structure is similar to that of cases with a preferential interpretation, the reading is clearly temporal; the poison does not prefer to do one thing (to kill) to another (the person feeling the poisoning), but, instead, turns out to be mortal before someone becomes aware of its effects. By contrast, in $(7 \mathrm{~b})$ the writer states that the father prefers to die himself instead of witnessing his son's death. However, in this case a temporal relationship between the two events, in principle, is also feasible, because if the father does not wish to see his son dying, inevitably he himself must die first. Examples like ( $7 \mathrm{~b})$, therefore, can be considered bridging contexts that give rise to the inference of preferential meaning (cf. Heine 2002). Finally, example (7c) can only have a preferential reading, i.e., the writer asserts that we prefer to help our relative or friend

10 However, Elvira (2009, p. 105) claims the adversative meaning can have arisen as a secondary or inferred reading of examples in which the temporal meaning was also present. He does not seem to assume a preferential meaning in between. 
instead of our neighbour; a temporal relation is very unlikely, if not inconceivable, since it is not the case that we will help our relative or friend before our neighbour.

Subsequently, in (8a) it could be inferred that the birds prefer to hide instead of leaving the caves, but, at the same time, the example can have a contrastive reading, given the marked antithesis between 'leaving the caves' and 'hide themselves', in which case 'rather' could be paraphrased with 'by contrast' or 'on the contrary'. Thus, (8a) and similar examples serve as bridging contexts that induce an inference in favour of the adversative meaning. On the other hand, in (8b) a preferential reading is excluded, since the first statement (es cosa honesta fazer lo que es prouechoso) is made by others ('they say'), whereas the second statement (es honesto non lo fazer) is made by the speaker ('I say'), so there is no comparison of two objects or acts by the same speaker at stake. Therefore, (8b) cannot but lead to an adversative interpretation. In fact, in ( $8 \mathrm{~b})$ there is a double contrast, i.e., between different speakers ('they' vs. ' $\mathrm{I}$ ') and between different assessments ('it is honest to do something' vs. 'it is honest to refrain from doing that thing').

(7) a. e diz aún que el venino o la poçón d'ellas que ante mata all omne que él sienta el su empoçonamiento, (Alfonso X, General estoria I, C13) "and he even says that the poison or the potion of them [a certain type of snakes] kills the man before he feels its poisoning,"

b. otrosy el padre ante querria ver la su muerte que la de su fijo (Sancho IV, Castigos y documentos para bien vivir, C14) "also the father rather (before) would want to see his death than that of his son"

c. mas sy plejto han en juyz'io. ante ayudaras al pariente $\mathcal{E}$ Al amigo. que al vez'ino. (Alonso de Cartagena, De los oficios, C15) "but when they have a lawsuit in court you will rather help your relative or friend than your neighbour."

(8) a. E las que estan en las arboles $\mathcal{E}$ en las cueuas non osan salir dellas ante punnan de se asconder quanto mas pueden. (Alfonso X, Libro de ajedrez, dados y tablas, C13) "and those [birds] that are in the trees and in the caves do not dare to leave them, rather (on the contrary) they struggle to hide as much as they can."

b. lo que dizen que es cosa honesta. faz'er lo que es prouechoso ante digo yo que es honesto. non lo faz'er (Alonso de Cartagena, De los oficios, C15) "what they say that it is honest to do what is beneficial, rather I say that it is honest not to do it"

In our corpus, the preferential meaning is always less frequent than the temporal and the adversative meanings and, except for the 15th century, the temporal meaning is always more frequent than the adversative one. The relevant data are shown in Table $3 .^{11}$

Taking into account the different genres, it turns out that, although there are some fluctuations per century, overall the percentages per meaning are quite similar; in all three text genres the temporal meaning is most frequent, followed by the adversative and, at a much lower rate, by the preferential meaning (Table 4). Globally, this pattern is maintained for every century, although in historiographical prose in the 14th and 15th century the adversative meaning is slightly more frequent than the temporal one, which is also the case for philosophical texts in the 15th century.

In view of the fact that at least from the 13th century onwards two similar adverbs are available, which apparently seem to be used indiscriminately to express temporal, preferential and adversative meaning, it is conceivable that in the course of time a redistribution of these meanings among the two forms took place. Although, as argued before, there is a semantic continuum between the three meanings, temporality can be placed at one end, whereas adversativity is clearly located at the other end, with preferential meaning bridging the semantic gap between both extremes.

11 In this and the following tables we do not incorporate the data from the 17th century, since they do not show variation between ante and antes. 
Table 3. Frequencies of temporal, preferential and adversative meaning per century.

\begin{tabular}{ccccc}
\hline Century & Temporal & Preferential & Adversative & Total \\
\hline 13 & $77.6 \%(413)$ & $0.9 \%(5)$ & $21.4 \%(114)$ & $100 \%(532)$ \\
14 & $50.3 \%(160)$ & $8.5 \%(27)$ & $41.2 \%(131)$ & $100 \%(318)$ \\
15 & $39.3 \%(90)$ & $10.9 \%(25)$ & $49.8 \%(114)$ & $100 \%(229)$ \\
16 & $53.6 \%(165)$ & $1.6 \%(5)$ & $44.8 \%(138)$ & $100 \%(308)$ \\
\hline total & $59.7 \%(828)$ & $4.5 \%(62)$ & $35.8 \%(497)$ & $100 \%(1387)$ \\
\hline \multicolumn{5}{c}{ chi-square $(6, N=1387)=157.165, p=0.000 * * *$}
\end{tabular}

Table 4. Frequencies of temporal, preferential and adversative meaning per text genre.

\begin{tabular}{ccccc}
\hline Genre & Temporal & Preferential & Adversative & Total \\
\hline Historiographical & $60.6 \%(531)$ & $3.2 \%(28)$ & $36.2 \%(317)$ & $100 \%(876)$ \\
Philosophical & $53.5 \%(147)$ & $10.5 \%(29)$ & $36 \%(99)$ & $100 \%(275)$ \\
Technical & $63.6 \%(150)$ & $2.1 \%(5)$ & $34.3 \%(81)$ & $100 \%(236)$ \\
\hline
\end{tabular}

historiographical chi-square $(6, N=876)=133.890, p=0.000 * * * ;$ philosophical chi-square $(6, N=275)=42.334$, $p=0.000^{* * *}$; technical chi-square $(6, N=236)=29.702, p=0.000^{* * *}$.

Therefore, we could hypothesize a dichotomy of form and meaning, in which ante, the etymological Latin form, would stick with the oldest temporal meaning, already present in the Latin ante, whereas antes, the diachronically later form, would seize the Romance novel meaning of adversativity. It should be mentioned that our hypothesis does not make a prediction about the expression of the preferential meaning by one of the two adverbs, since preferential cases on the one hand can be grouped with temporal cases, in which they clearly originate, but on the other hand are also clearly linked to adversative cases, with which they share the meaning of abstract precedence. However, as Table 3 shows, preferential meaning has always been fairly rare in both adverbs.

To test this idea of semantic differentiation, we calculated percentages for ante and antes with the three meanings. Table 5 displays the results.

Table 5. Frequencies of ante and antes per meaning (temporal, preferential, adversative) and per century.

\begin{tabular}{ccccc}
\hline Century & & ante & antes & Total \\
\hline \multirow{4}{*}{13} & Temporal & $23.5 \%(97)$ & $76.5 \%(316)$ & $100 \%(413)$ \\
& Preferential & $40 \%(2)$ & $60 \%(3)$ & $100 \%(5)$ \\
& Adversative & $21.1 \%(24)$ & $78.9 \%(90)$ & $100 \%(114)$ \\
\hline \multirow{3}{*}{14} & Temporal & $37.5 \%(60)$ & $62.5 \%(100)$ & $100 \%(160)$ \\
& Preferential & $40.7 \%(11)$ & $59.3 \%(16)$ & $100 \%(27)$ \\
& Adversative & $18.3 \%(24)$ & $81.7 \%(107)$ & $100 \%(131)$ \\
\hline \multirow{3}{*}{15} & Temporal & $56.7 \%(51)$ & $43.3 \%(39)$ & $100 \%(90)$ \\
\cline { 2 - 5 } & Preferential & $44 \%(11)$ & $56 \%(14)$ & $100 \%(25)$ \\
\cline { 2 - 5 } & Adversative & $27.2 \%(31)$ & $72.8 \%(83)$ & $100 \%(114)$ \\
\hline \multirow{3}{*}{16} & Temporal & $18.8 \%(31)$ & $81.2 \%(134)$ & $100 \%(165)$ \\
\cline { 2 - 5 } & Preferential & $0 \%(0)$ & $100 \%(5)$ & $100 \%(5)$ \\
\cline { 2 - 5 } & Adversative & $21 \%(29)$ & $79 \%(109)$ & $100 \%(138)$ \\
\hline
\end{tabular}

C13 chi-square $(2, N=532)=1.107, p=0.575 ;{ }^{12} \mathrm{C} 14$ chi-square $(2, N=318)=14.310, p=0.001 * * * ; \mathrm{C} 15$ chi-square $(2$, $N=229)=18.462, p=0.000^{* * *} ;$ C 16 chi-square $(2, N=308)=1.467, p=0.480^{12}$.

12 Two cells (33.3\%) have an expected count of less than 5. 
The results of Table 5 do not give evidence of an indisputable gradual spread of antes over the different semantic contexts, i.e., we do not observe a situation whereby antes grasps one meaning at a time (cf. Aitchison 2013, p. 112). Rather, our data point to a state of affairs in which from the 13th to the 16th century the use of adversative antes is always much greater than adversative ante. For example, in the 13 th century a figure of $78.9 \%$ is registered for antes with adversative meaning, as opposed to $21.1 \%$ for ante with this same meaning. This pattern is repeated throughout the centuries. Moreover, in every century the percentage of ante's temporal meaning is higher than the percentage of its adversative meaning, except for the 16th century, when ante definitely loses ground as an adverb. Thus, our data reflect a fuzzy situation of co-existence of the two adverbs just before the final blow by antes in the 17th, when ante no longer counted as an adverbial solution (cf. Aitchison 2013, pp. 130-32). ${ }^{13}$

\section{Discussion and Conclusions}

We now turn to the question whether the case of the doublet ante-antes can be conceived as an example of exaptation, a concept which Lass (1990) borrowed from evolutionary biology and applied to language change to describe changes whereby a grammatical distinction coded morphologically is lost without the loss of the corresponding morphological material. This morphology then becomes 'junk', useless material, which subsequently can be exploited for some other function. Lass further states that the domain of exaptation does not have to be morphosyntactic. He considers the semantic splitting of doublets also exaptive, since "if two forms code one meaning, one form is (potential) junk" (1990: 94, note 10).

Over the years, Lass' proposal has been discussed intensively and extensively for different languages. Thus, Vincent (1995) analyses examples from the Romance languages, and Norde (2001) explores the concept of exaptation in the context of Swedish, while Narrog (2007) examines processes of exaptation in Japanese (for a review of some of the early studies on exaptation, see (Traugott 2004)). Particularly, many studies question the notion of 'junk morphology' and, indeed, in later work Lass (1997, pp. 316-24) himself modifies his original idea stating that the availability of junk is not a sine qua non in order for exaptation to take place, and that, on the contrary, functional material can also be exapted. De Cuypere (2005) holds a fairly pessimistic view of the usefulness of the concept of exaptation stating that it "comprises such a broad spectrum of changes that the concept reduces to mere triviality". By contrast, Gardani (2016) argues that exaptation provides valuable insights into the investigation of diachronic change.

Smith (2011, p. 268) calls the kind of language change Lass is referring to 'refunctionalization' or 'adfunctionalization', depending on whether the new function replaces the old one or is simply added to it. Pountain (2000, p. 295) uses the term 'capitalization', in "an attempt to label the historical process by which a linguistic feature which already exists in a language comes to be substantially exploited for wider purposes, sometimes simply making overt distinctions which were previously covert, but sometimes apparently creating new expressive possibilities". Pountain (2000, p. 295)

Finally, in their recent volume on exaptation and language change Norde and Velde (2016, p. 10) adopt a broader, slightly different definition of exaptation, i.e., "the leap-like co-optation of a trait for a new function that is not immediately related to its former function". ${ }^{14}$

Whereas the final $-s$ in Old Spanish could serve to mark adverbs, unarguably in the course of time it lost this function, given that in standard Modern Spanish the only productive adverbial suffix is -mente. ${ }^{15}$ Instead, according to Penny (2004, p. 131) adverbial -s was only an informal means to mark

13 This pattern is repeated in every text genre separately. However, the results are only statistically significant in the case of philosophical prose.

14 See for a thorough state-of-the-art discussion of the notion of exaptation also Norde and Velde (2016, pp. 1-35).

15 Pato and Casanova (2017) report the existence of adverbial cercas alongside cerca in contemporary Mexican Spanish. According to the authors, cercas must be a recent creation, based on analogy with other adverbs that end in $-s$ (such as lejos), since a diachronic review of the form only rendered four occurrences, dating from the 14 th to the beginning of the 17 th century. Note that currently cercas is a highly stigmatized form in Mexico. Given its recent development and the lack of 
adverbial function, too irregularly applied to count as a genuine suffix. The adverbial morpheme, therefore, at some point in time must have become a sort of junk and must have been no longer recognized as adverbial marker. Now, as Lass $(1990$, p. 82) states:

here are three things that can in principle be done with it: (i) it can be dumped entirely; (ii) it can be kept as marginal garbage or nonfunctional/nonexpressive residue (suppletion, 'irregularity'); (iii) it can be kept, but instead of being relegated as in (ii), it can be used for something else, perhaps just as systematic. (cf. also Lass 1997, p. 317)

Since ante and antes could both convey different meanings, the felicitous presence of the final $-s$ in antes could be exploited for semantic purpose, i.e., it could be capitalized in order to encode the semantic opposition between the temporal meaning (adverbial ante) and the adversative meaning (adverbial antes). Indeed, our data show a tendency towards Lass' option (iii), as long as both forms are in use as adverbs. ${ }^{16}$ Admittedly, the described tendency does not comply with the definition of exaptation as proposed by Norde and Velde (2016, p. 10), because, as argued before, the different meanings of ante and antes fit in a semantic continuum, being the temporal meaning related to the preferential one, which in turn shares the notion of precedence with the adversative. For that reason, there is no new function involved. Vincent (1995, p. 435, note 4) states:

in the case of exaptation either the meaning was not previously encoded so that only the form pre-exists or else both form and meaning are already present but not combined in the same linguistic sign. (Vincent 1995, p. 435)

The adversative meaning of antes arguably corresponds to the second option of Vincent's definition of exaptation, for in Old Spanish there were other means to convey this meaning, for example, sino ('but') and más bien ('rather'), to mention just two connectives (cf. Elvira 2009; Garachana Camarero 1998; Nieuwenhuijsen 2012).

In the course of the 16th century, ante comes to be exclusively used as a preposition, whereas antes generalizes for adverbial function. Thus, the phonological opposition between ante and antes is exploited to create a clear-cut distinction between word classes. Figure 1 sums up the different functions and meanings of ante and antes and visualizes the changes both forms experienced in the course of time.

The word class distinction inevitably leads to the collapse of the hesitant differentiation between ante expressing temporality and antes expressing adversativity, since, as a consequence, the use of ante as an adverb obviously is ruled out.

Within the scope of the present paper we can only speculate about the cause of this collapse. Certainly, the redistribution of meanings would have led to a transparent distinction between forms and temporal meaning (ante) vs. adversative meaning (antes). However, ante with spatial meaning, inherited from Latin, had always been available in Spanish. Therefore, the semantic differentiation of adverbial ante and antes only sorted out the possible opacity as far as the temporal and adversative meanings were concerned, but it did not take into account the spatial meaning. So, the outcome of this change inevitably would entail a new type of opacity, i.e., the fact that ante designated space as well as time.

Moreover, although in many instances there is a fairly clear semantic difference between the temporal meaning on the one hand and the preferential and adversative meaning on the other hand,

historical evidence, we do not think the existence of contemporary Mexican cercas challenges the claim of unproductiveness of the Old Spanish adverbial suffix $-s$.

16 Interestingly, as mentioned before, other Spanish adverbial doublets chose other options depending on the specific word pair. In the case of fuera-fueras ('outside', 'except'), the second form with final $-s$ has not survived in Modern Spanish (option i); the two members of the doublet quizá-quizás ('perhaps') are both valid forms in Modern Spanish, so the final -s can be considered a non-functional residue of ancient times (option ii). By contrast, in the case of entonces ('so') only the form with final $-s$ has survived. 
these differences perhaps were not salient enough to impose a definitive semantic redistribution of ante and antes, although it does seem to have prompted the distribution as documented in our corpus spanning the period from the 13 th to the 16 th century.

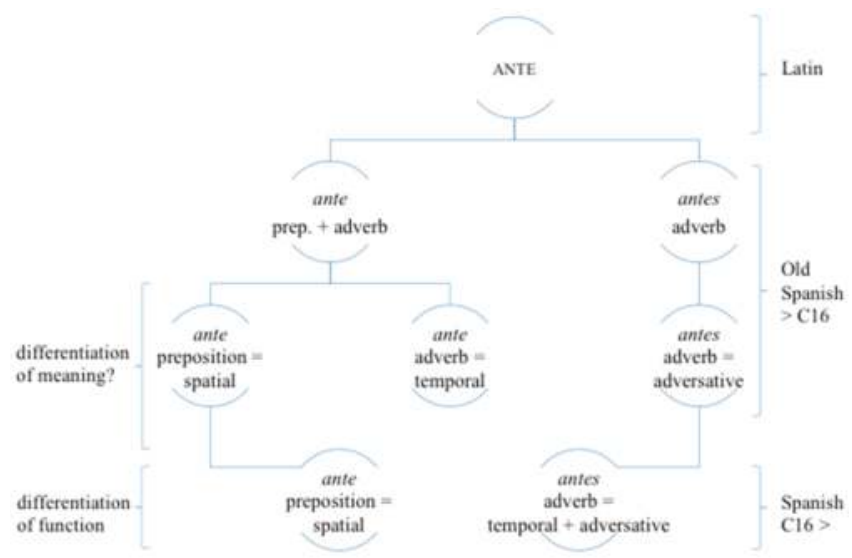

Figure 1. Different functions and meanings of ante and antes in diachronic perspective.

By contrast, the final differentiation created a clear distinction in function between prepositional ante and adverbial antes. At the same time, the change resulted in a distinction between spatial meaning (ante) as opposed to temporal, preferential adversative meaning (antes). It is this distinction that, in retrospect, has prevailed.

Corpus: GRADIA = Corpus compiled by the research group GRADIA. http://gradiadiacronia.wixsite.com/ gradia/corpus-gradia.

Conflicts of Interest: The author declares no conflict of interest.

\section{References}

Alvar, Manuel, and Bernard Pottier. 1993. Morfología Histórica del Español. Madrid: Gredos.

Aitchison, Jean. 2013. Language Change: Progress or Decay? 4th ed. Cambridge: Cambridge University Press.

Azofra Sierra, Elena. 2014. Adverbios de tiempo. Demostrativos comparativos y modo-temporales. In Sintaxis histórica de la lengua española. Tercera parte: Preposiciones, adverbios y conjunciones. Relaciones interoracionales. Edited by Concepción Company Company. Mexico City: Universidad Nacional Autónoma de México \& Fondo de Cultura Económica, vol. 1, pp. 313-410.

Corominas, Joan, and José A. Pascual. 1984. Diccionario Crítico Etimológico Castellano e Hispánico. Madrid: Gredos.

Cuervo, Rufino J. 1886/1994. Diccionario de construcción y régimen de la lengua Castellana; Bogotá: Instituto Caro y Cuervo.

De Cuypere, Ludovic. 2005. Exploring exaptation in language change. Folia Linguistica Historica 26: 13-26. [CrossRef]

Elvira, Javier. 2009. Conectores contraargumentativos e castellano medieval. Cahiers d'études hispaniques médiévales 32: 101-15. [CrossRef]

Espinosa Elorza, Rosa M. 2010. Procesos de formación y cambio en las llamadas "palabras gramaticales". San Millán de la Cogolla: Cilengua.

Garachana Camarero, Mar. 1998. La noción de preferencia en la gramaticalización de ahora (que), ahora bien, antes, antes bien y más bien. In Estudios de lingüística cognitiva. Edited by José Luis Cifuentes Honrubia. Alicante: Universidad de Alicante, vol. 2, pp. 593-614.

Gardani, Francesco. 2016. Allogenous exaptation. In Exaptation and Language Change. Edited by Muriel Norde and Freek Van de Velde. Amsterdam and Philadelphia: John Benjamins, pp. 227-60.

Glare, P. G. W. 1968-1982. Oxford Latin Dictionary. Oxford: At het Claredon Press. 
Heine, Bernd. 2002. On the role of context in grammaticalization. In New Reflections on Grammaticalization. Edited by I. Wischer and G. Diewald. Amsterdam and Philadelphia: John Benjamins, pp. 83-102.

Herrero Ruiz de Loizaga, F. Javier. 2005. Sintaxis histórica de la oración compuesta en español. Madrid: Gredos.

Iglesias Recuero, Silvia. 2014. Oraciones adversatives. In Sintaxis histórica de la lengua española. Tercera parte: Preposiciones, adverbios y conjunciones. Relaciones interoracionales. Edited by Concepción Company Company. Mexico City: Universidad Nacional Autónoma de México \& Fondo de Cultura Económica, vol. 2, pp. 2519-669.

Keniston, Hayward. 1937. The Syntax of Castilian Prose. The Sixteenth Century. Chicago: The University of Chicago Press.

Lass, Roger. 1990. How to do things with junk: Exaptation in language evolution. Journal of Linguistics 26: 79-102. [CrossRef]

Lass, Roger. 1997. Historical Linguistics and Language Change. Cambridge: Cambridge University Press.

Menéndez Pidal, Ramón. 1976. Cantar de Mio Cid. Texto, Gramática y Vocabulario. Madrid: Espasa Calpe.

Menéndez Pidal, Ramón. 1982. Manual de Gramática Histórica Española. Madrid: Espasa Calpe.

Narrog, Heiko. 2007. Exaptation, Grammaticalization, and Reanalysis. California Linguistics Notes 32: 1-24.

Nebrija, Elio A. de. 1495/1951. Vocabulario español-latino. Madrid: Editorial Castalia.

Nieuwenhuijsen, Dorien. 2012. No es temporal, antes es adversativo: historia del valor adversativo de antes. In Actas del VIII congreso internacional de historia de la lengua Española. Edited by Emilio Montero Cartelle. Santiago de Compostela: Meubook, vol. I, pp. 995-1005.

Norde, Muriel. 2001. Deflexion a a counterdirectional factor in grammatical change. Language Sciences 23: 231-64. [CrossRef]

Norde, Muriel, and Freek Van de Velde. 2016. Exaptation. Taking stock of a controversial notion in linguistics. In Exaptation and Language Change. Edited by Muriel Norde and Freek Van de Velde. Amsterdam and Philadelphia: John Benjamins, pp. 1-35.

Octavio de Toledo y Huerta, Álvaro S. 2014. Otras preposiciones locativas y construcciones afines. In Sintaxis histórica de la lengua española. Tercera parte: Preposiciones, adverbios y conjunciones. Relaciones interoracionales. Edited by Concepción Company Company. Mexico City: Universidad Nacional Autónoma de México \& Fondo de Cultura Económica, vol. 2, pp. 1837-2053.

Ortiz Ciscomani, Rosa M. 2014. Locuciones adverbiales con a y base léxica en -as. In Sintaxis histórica de la lengua española. Tercera parte: Preposiciones, adverbios y conjunciones. Relaciones interoracionales. Edited by Concepción Company Company. Mexico City: Universidad Nacional Autónoma de México \& Fondo de Cultura Económica, vol. 1, pp. 1117-92.

Pato, Enrique, and Vanessa Casanova. 2017. El hotel está muy cercas de la playa, o la falsa pluralización del adverbio cerca en el español de México. Anuario de Letras. Lingüística y Filología 1: 147-67.

Penny, Ralph. 2004. A History of the Spanish Language, 2nd ed. Cambridge: Cambridge University Press.

Pountain, Christopher J. 2000. Capitalización. In Historical Linguistics 1995. Selected papers from the 12th International Conference on Historical Linguistics (= Current Issues in Linguistic Theory, 161). Edited by John Charles Smith and Delia Bentley. General Issues and non-Germanic Languages. Amsterdam and Philadelphia: John Benjamins, vol. 1, pp. 295-309.

Real Academia Española. 2005. Diccionario Panhispánico de Dudas. Available online: http://www.rae.es/ recursos/diccionarios/dpd (accessed on 11 January 2016).

Smith, John C. 2011. Change and Continuity in Form-Function Relationships. In The Cambridge History of the Romance Languages. Edited by Martin Maiden, John Charles Smith and Adam Ledgeway. Cambridge: Cambridge University Press, vol. 1, pp. 268-317.

Traugott, Elizabeth Closs. 2004. Exaptation and Grammaticalization. In Linguistic Studies Based on Corpora. Edited by Minoji Akimoto. Tokyo: Hituzi Syobo Publishing, pp. 133-56.

Vincent, Nigel. 1995. Exaptation and grammaticalization. In Historical Linguistics 1993: Selected papers from the 11th International Conference on Historical Linguistics (= Current Issues in Linguistic Theory, 124). Edited by Henning Andersen. Amsterdam and Philadelphia: John Benjamins, pp. 433-45.

(C) 2018 by the author. Licensee MDPI, Basel, Switzerland. This article is an open access article distributed under the terms and conditions of the Creative Commons Attribution (CC BY) license (http:/ / creativecommons.org/licenses/by/4.0/). 
MDPI

St. Alban-Anlage 66

4052 Basel

Switzerland

Tel. +41616837734

Fax +41 613028918

www.mdpi.com

Languages Editorial Office

E-mail: languages@mdpi.com

www.mdpi.com/journal/languages

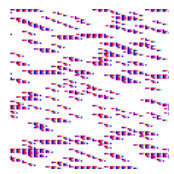



MDPI

St. Alban-Anlage 66

4052 Basel

Switzerland

Tel: +41 616837734

Fax: +41 613028918

www.mdpi.com 